Budapesti Corvinus Egyetem

Élelmiszertudományi Kar

Élelmiszertudományi Doktori Iskola

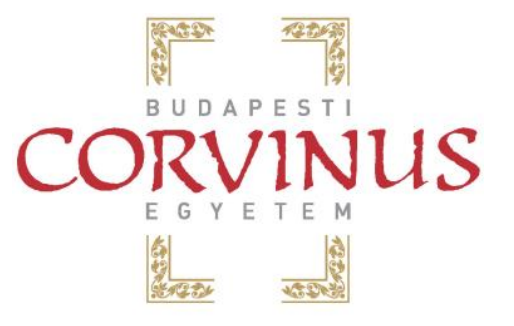

Élelmiszertudományi Kar

Doktori $(\mathrm{PhD})$ értekezés

\title{
Ökológiai és integrált gazdálkodással termesztett csonthéjas és almatermésű gyümölcsök mikrobiológiai és kémiai analízise
}

\author{
Készítette: \\ Pintér Szilvia \\ Témavezető: \\ Dr. Beczner Judit, Csc.
}

Készült a Központi Környezet-és Élelmiszer-tudományi Kutatóintézet Mikrobiológiai Osztályán, melynek jogutódja a NAIK Agrárkörnyezet-tudományi Kutatóintézet Környezeti és Alkalmazott Mikrobiológiai Osztálya

Budapest 


\section{Tartalomjegyzék}

1. TARTALOMJEGYZÉK

A DOLGOZATBAN ELÖFORDULÓ RÖVIDÍTÉSEK: ..............................................................................4

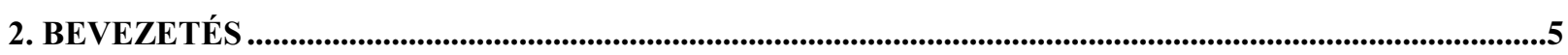

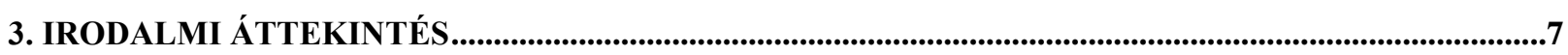

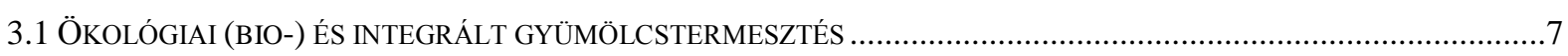

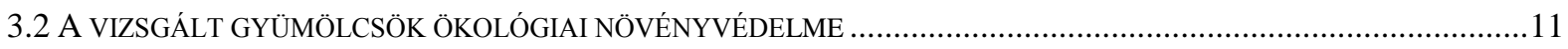

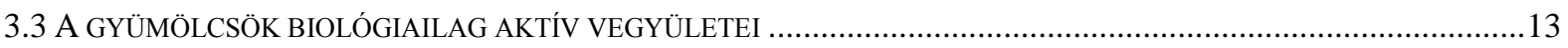

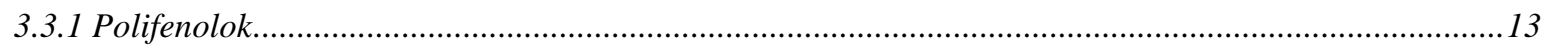

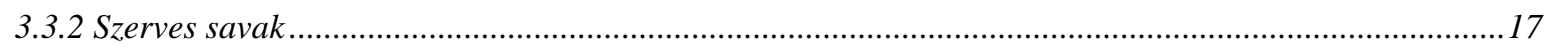

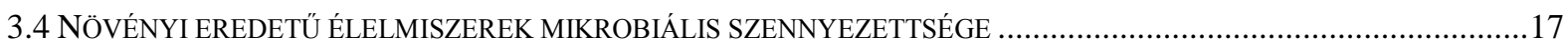

3.5 A GYÜMÖLCSÖK ÉRÉSE ÉS ROMLÁSI FOLYAMATA.............................................................................22

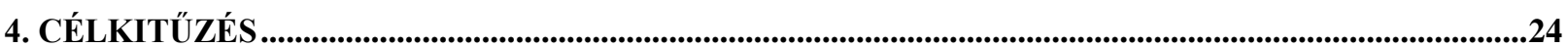

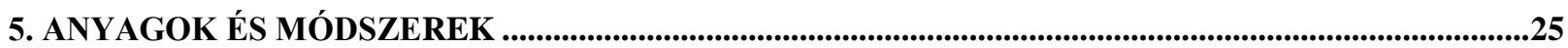

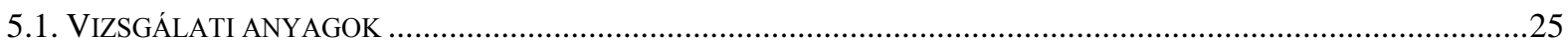

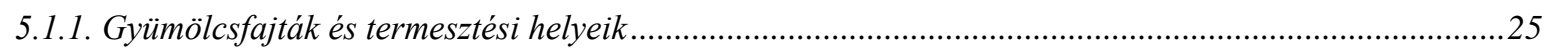

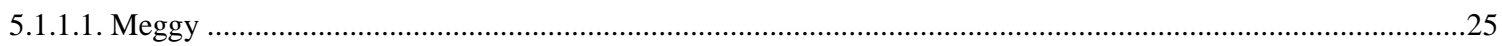

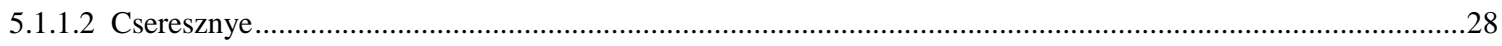

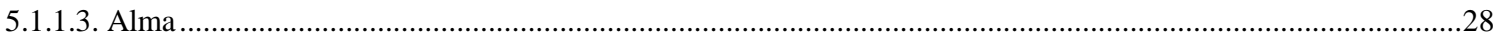

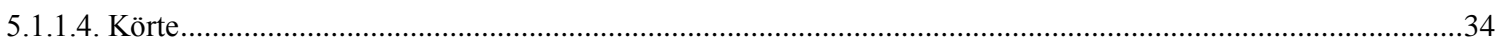

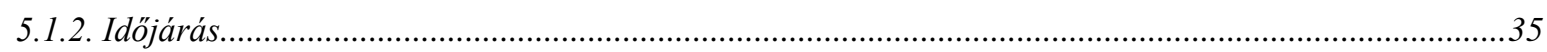

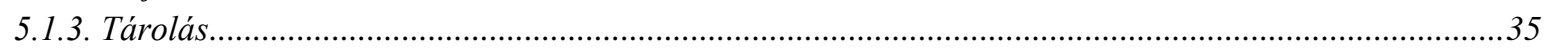

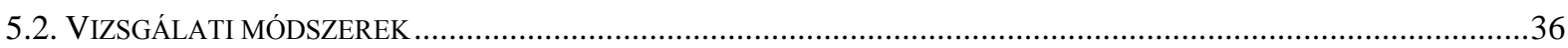

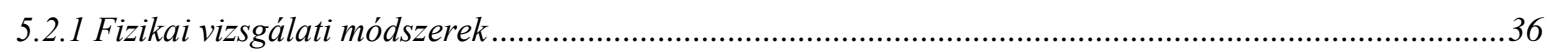

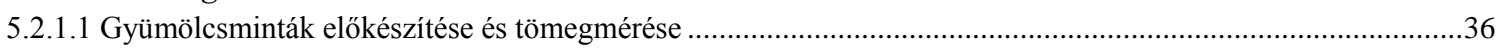

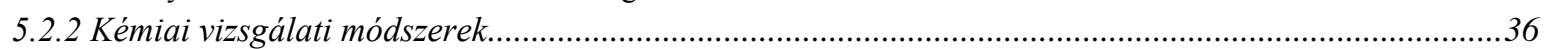

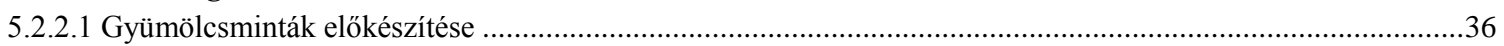

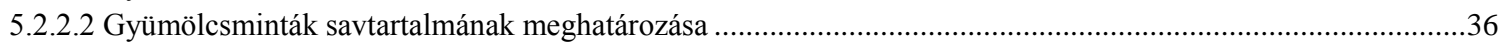

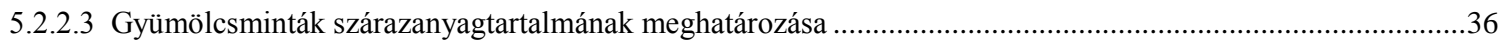

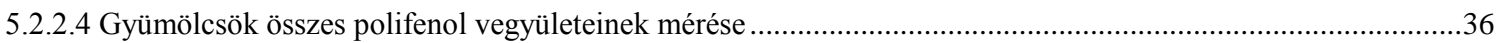

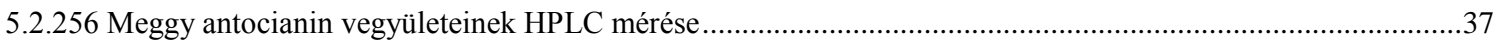

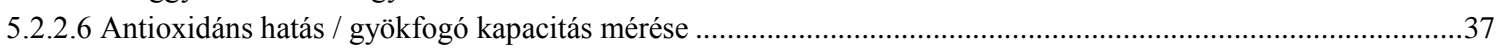

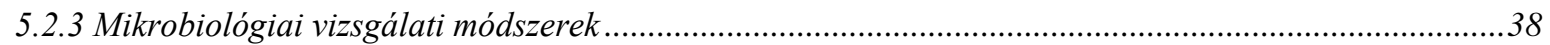

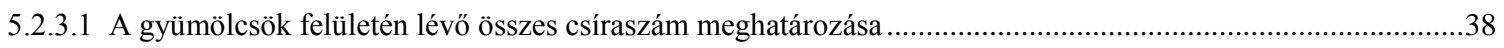

5.2.3.2 A gyümölcsök felületén lévő élesztö- és penészgomba meghatározása......................................................38

5.2.3.3 A gyümölcsök felületén lévő indikátor mikroorganizmusok meghatározása …............................................38

5.2.3.4 A gyümölcsök felületén lévő patogén mikrobák meghatározása .....................................................................39

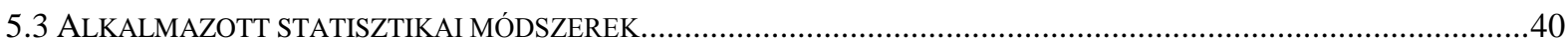

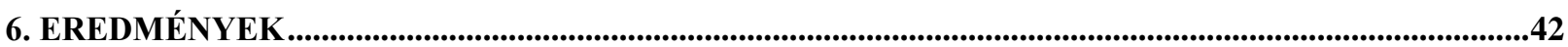

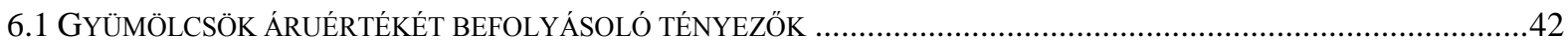

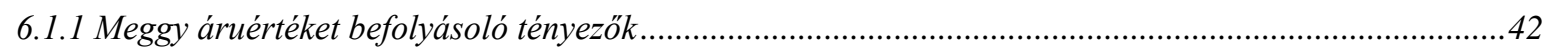

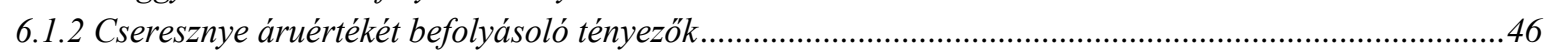

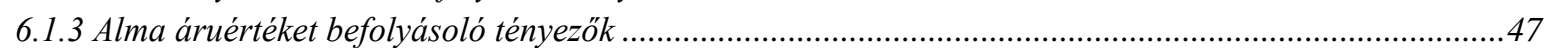

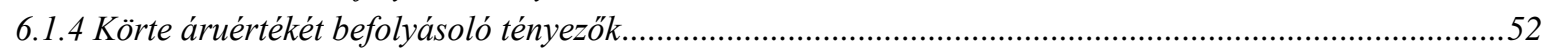

6.2 GYÜMÖLCSÖK FELHASZNÁLÁSI ÉRTÉKÉT BEFOLYÁSOLÓ BELTARTALMI ÖSSZETEVÖK ...................................53

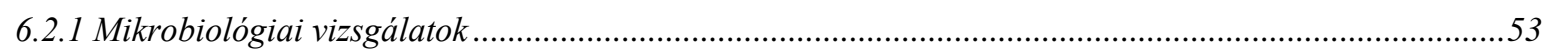

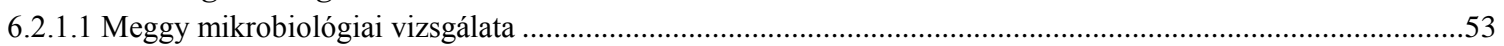

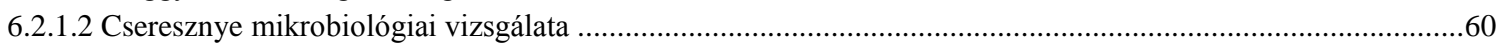

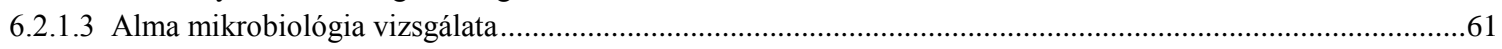

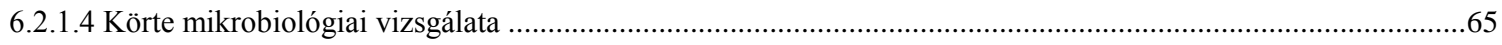

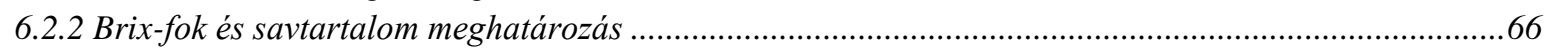

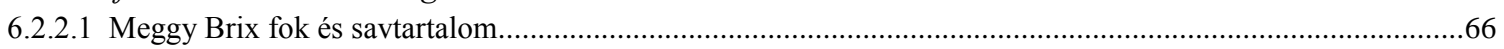




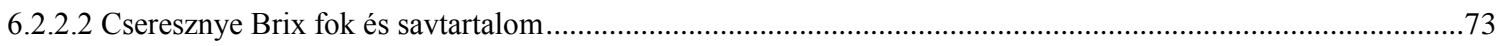

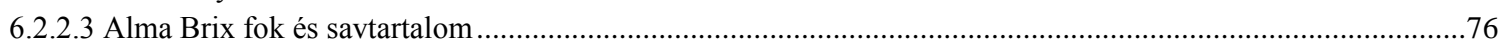

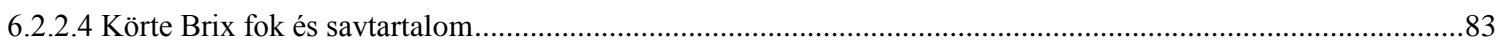

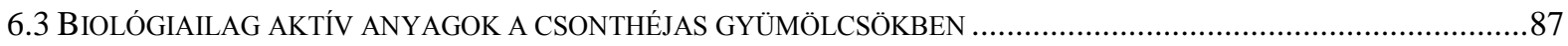

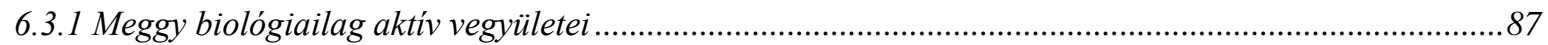

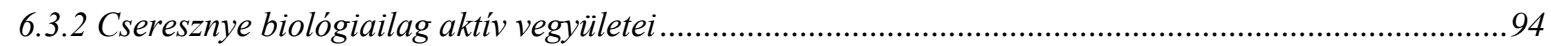

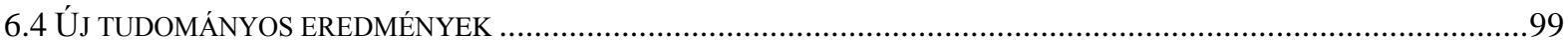

7. A KUTATÁSI EREDMÉNYEK ÖSSZEFOGLALÁSA ÉS JAVASLATOK..............................................100

8. SUMMARY OF RESEARCH RESULTS AND PROPOSALS ........................................................103

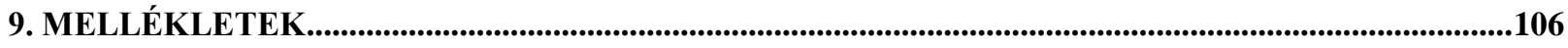

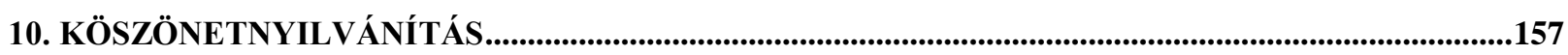




\section{$\underline{\text { A dolgozatban előforduló rövidítések: }}$}

tke: telepképző egység (mikrobiológiai)

E. coli: Escherichia coli (mikrobiológiai)

Pseudoonas a.: Pseudomonas aeruginosa (mikrobiológiai)

L. monocytogenes: Listeria moncytogenes (mikrobiológiai)

ALOA agar : Agar Listeria acc. to Ottaviani \& Agosti agar (mikrobiológiai)

XLD agar: Xylose lysine deoxycholate agar (mikrobiológiai)

TSA agar: Tryptic Soy Agar (mikrobiológiai)

TGE (PCA): Tryptone Glucose Extract Agar (Plate Count Agar)

API teszt: miniatürizált biokémiai teszt mikrobák meghatározására (mikrobiológiai)

DPPH: 2,2-difenil-pikrilhidrazid (antioxidáns kapacitás mérésénél használt) (analitika)

MeOH: metil-alkohol (analitika)

HPLC: High Performance Liquid Chromatography (Nagy teljesítményü

folyadékkromatográfia) (analitika)

GAE: galluszsav-ekvivalens (analitika) 


\section{Bevezetés}

Az utóbbi évtizedben egyre inkább előtérbe kerül az egészséges és korszerü táplálkozás. Ezeknek a fogyasztói igényeknek a kiszolgálása folyamatos változást igényel mind élelmiszeripartól, mind a mezőgazdaságtól. Egyre keresettebbek a reform-táplálkozás jegyében előállított élelmiszerek, illetve számos más irányzat termékei (paleo diéta, vegetáriánus ételek, szénhidrátszegény diéta stb.). Fokozatosan előtérbe kerül az egészségtudatos táplálkozás világszerte, de föleg Európában. Ennek fontos komponensei a növényi eredetủ élelmiszerek és azok közül is a disszertációban szereplő, vizsgálatom alapját képező - gazdasági és táplálkozásélettani szempontból is kiemelkedö- gyümölcsök. A Magyarországon legnagyobb mennyiségben elöállított gyümölcs az alma, majd ezt követi a meggy. Szintén jelentős és igen nagy mennyiségben termelt gyümölcs a körte és a cseresznye (1. ábra). A Magyarországon megtermelt legfontosabb gyümölcsök (1. ábra) mennyisége a 2010-ben összesen 732 ezer tonna volt, melynek 68\%-át az alma adja (KSH, 2012), s hasonló tendencia várható a következő években is. A meggy elsősorban Kelet-Európa gyümölcse, Magyarország szerepe ebben a térségben meghatározó. A meggyet gyümölcstermesztésünk húzóágazatának tekintjük, termelési értéke és exportjának nagysága miatt is. Az elkövetkezendő években a termelés növekedésével lehet számolni világviszonylatban is.

A másik fontos irányzat a fenntartható gazdálkodási rendszerek jegyében egyre inkább elterjedtebbé váló ökológiai gazdálkodás. Az ökológiai gazdálkodási rendszer, mely ugyanúgy, mint a hagyományos vagy integrált termesztési mód, jóízü és autentikus élelmiszereket termel, de a természetes körfolyamatok tiszteletben tartásával. Az ilyen gazdálkodás során, legyen szó akár növénytermesztésről, akár állattenyésztésröl, csökkentik az ember hatását a környezetre, miközben biztosítják a mezőgazdasági rendszerek lehető legtermészetesebb müködését.

Egyre fontosabbá válik a kiemelkedő beltartalmi és biológiai aktivitással rendelkező gyümölcsfajták felkutatása, termesztése, friss fogyasztása és ipari célra történő nemesítése. A meggy és alma nemesítésére kiemelkedő jelentőségü intézmények alakultak, például az Újfehértói Gyümölcstermesztési Kutató és Szaktanácsadó Kht., ahonnan a meggy minták nagy részét és az alma minták egy részét kaptuk. A kutató központ az észak-magyarországi tájszelekcióval a meggy fajták megőrzésével és új fajták nemesítésével jelentős tevékenységet folytat.

Munkám során a fenti négyféle gyümölcs (meggy, cseresznye, alma, körte) fontosabb, az áruértéket jellemző paramétereinek és beltartalmi értékének vizsgálatát végeztem el. A meggy 
és alma esetében párhuzamosan vizsgáltam integrált és ökológiai termesztésböl származó gyümölcsöket a három éves vizsgálati időszakban (2008-2009-2010).

Nem elhanyagolható szempont az utóbbi években az élelmiszerbiztonság. Az Európai Unióban szigorú követelmények vonatkoznak mind a tagállamok által előállított, mind a külső országokból behozott élelmiszerekre. Munkám célja volt, hogy megvizsgáljama gyümölcsök felületi mikrobás szennyezettségét, tekintettel az indikátor és patogén mikrobák előfordulására is, valamint a fontosabb beltartalmi értékek alakulását a fajta, termesztési hely, a termesztési mód és az évjárat függvényében.

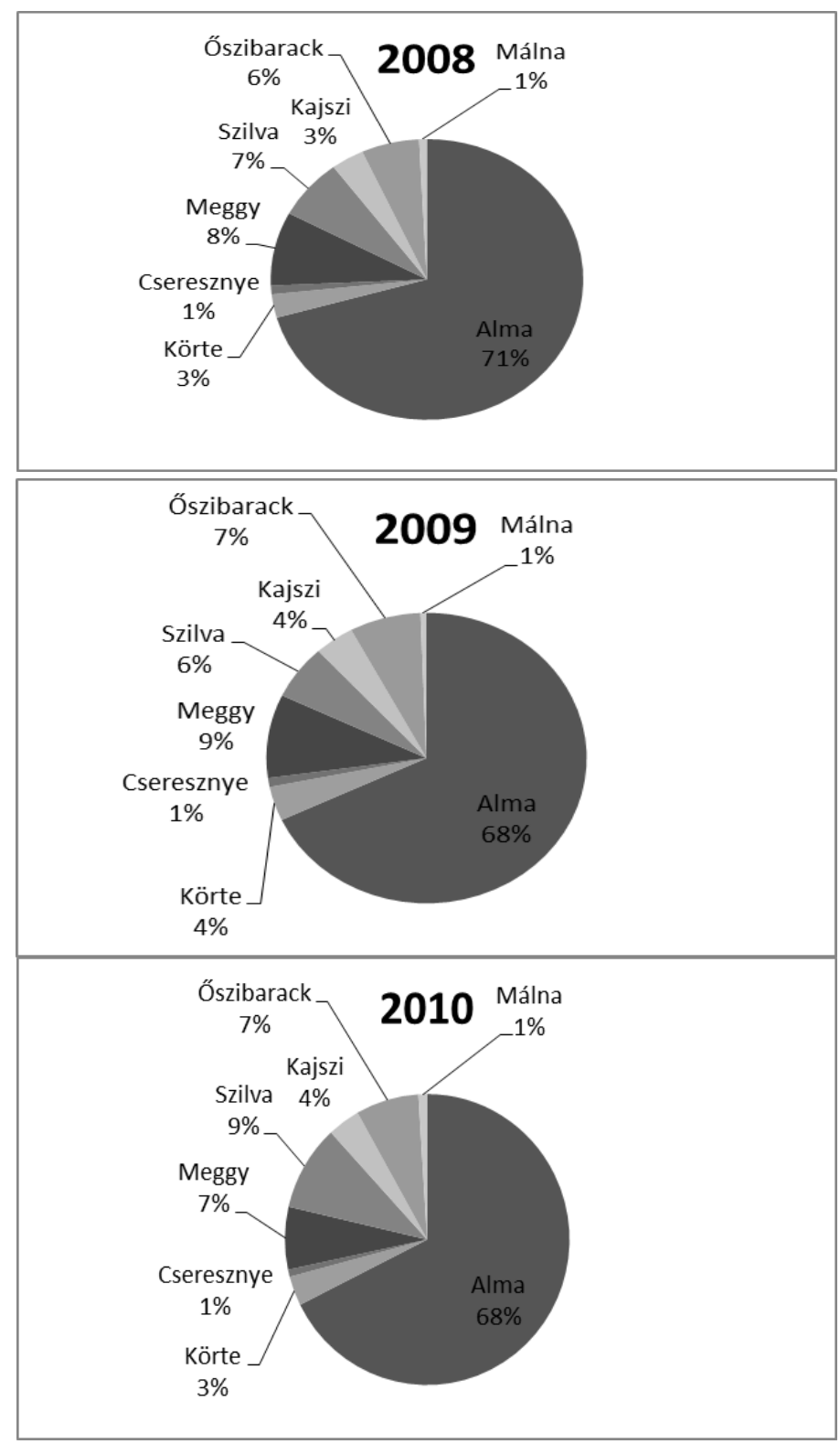

1. ábra: KSH adatai szerinti fontosabb gyümölcsök termésmennyisége (2008-2009-2010) 


\section{Irodalmi áttekintés}

\section{1 Ökológiai (bio-) és integrált gyümölcstermesztés}

Az 1970-es évekig az élelmiszertermelés elsődleges szempontja a világon és így Magyarországon is, a megtermelt mennyiség volt, tekintettel a két világháború között és a II. világháború után kialakult élelmiszerhiányra és éhinségre. Ennek egyik eszköze az un. extenzív mezőgazdaság volt, amely a megfelelő fajták és termesztési mód mellett a növényvédőszerek intenzív használatát is jelentette, ezenkívül, kis tőszám/ha-t alkalmaztak, és az összes termésmennyiség növelését nem a fajlagos termésmennyiség, hanem a termőfelület növelésével érték el. Az 1980-as évektől kezdve az un. intenzív termelés volt jellemző, melynél kis tenyészterület igényü, nagy tőszámú ültetvényeket létesítettek nagy produktivitású, kiváló gyümölcsminőségű fajtákkal. Az ökológiai gazdálkodás (biotermelés) gondolata Angliában és Németországban már a 20. század elején felvetődött. Követőkről alig lehetett beszélni, mert esélyük sem volt a mennyiségi termesztési szemlélet évtizedeiben. A fejlődésnek ezen a területen a század eleji gazdasági válság és a két világháború sem kedvezett (Soltész, 2005). A 70-es évek után fokozatosan fontossá vált a megtermelt élelmiszer minősége és a termelés módja is. A 90-es évek elejétől agrár-környezetvédelmi programok indultak és előtérbe került az élelmiszerbiztonság. A mezőgazdasági termelésben új kihívások jelennek meg. Többek között a környezet védelme, a természeti értékek megörzése, a természeti erőforrások ésszerü kihasználása. A XXI. század elejére a fejlett országokban a fogyasztók tudatosságának következtében az élelmiszernek nemcsak a minősége és ára, hanem annak elóélete is meghatározóvá vált. Kidolgozásra kerül az élelmiszerlánc, a „termőföldtől az asztalig” szemlélet (agri-food chain), amelynek során egyértelművé válik, hogy az élelmiszerminőség és biztonság már a szántóföldön elkezdődik. Ez egy olyan speciális minőségbiztosítási rendszer, amely magába foglalja az egészséges, a fogyasztóra mindenféle káros anyagtól mentes élelmiszert, az azt ellenőrző és tanúsító intézményrendszert, de tágabb értelemben azt a környezetet is, ahol az élelmiszer elöállítása történik. Ugyanis, ha az élelmiszer alapanyag termelése, előállítása során nem tudjuk biztosítani a teljes termelési folyamatban a kiváló minőséget, az élelmiszeripari feldolgozás során már nemigen lehet abból az alapanyagból jó minőségü élelmiszert előállítani. A növényi eredetű élelmiszereket veszélyeztető egyes veszélyforrások meghatározzák a minőségüket. Ilyen veszélyforrás a mikrobiológiai szennyezettség, a növényvédőszer maradék, a nehézfémek a talajból, műtrágyából, a természetben előforduló toxinok (pl. patulin, aflatoxin). Az élelmiszerbiztonság hangsúlyozásával a növényi élelmiszereknél a mezőgazdaságot minden országban arra 
ösztökélik, hogy lehetöleg környezetkímélő termesztési és növényvédelmi technológiákat alkalmazzanak. Napjaink környezetkímélö technológiái közül az integrált és az ökológiai (bio-) termesztési technológiák a legismertebbek és legelterjedtebbek. Az integrált termesztés olyan termesztési forma, ahol a termőhely, a fajta kiválasztása, a növényvédelem a lehető legkisebb mennyiségü kémiai anyag felhasználására irányulva történik, és a felhasznált mennyiséget is környezetkímélő módon, az éppen aktuális helyzethez alkalmazkodva, nem pedig elöírt tervek szerint kerül felhasználásra (Dickler, 1990). A növényvédelem az integrált termesztés fontos eleme, amelyben nem a növényi károsítók teljes kiírtása a cél, hanem azok veszélyességi küszöb alatt tartása (Holb, 2005). Valamennyi károsító elleni védekezés során előnyben részesítik a mechanikai, az agrotechnikai, a biológiai, és biotechnológiai módszerek alkalmazását. Ugyanakkor fontos tény, hogy, mivel engedélyezettek bizonyos kemikáliák, van lehetőség a termesztési hibák korrigálásra. Fontos elve a rendszernek, hogy csak a hatékony védekezéshez szükséges minimális mennyiséget alkalmazzák, amennyi a hatékony védekezéshez szükséges. Nemzeti és nemzetközi szabályzatok segítik az integrált gyümölcstermesztést. A növényvédőszerek hatóanyagait három csoportba sorolják (zöld, sárga, piros). A zöld csoportban olyan készítmények vannak, amelyek környezetvédelmi és közegészségügyi szempontból legkevésbé kifogásolhatóak. Piros csoportba kerülnek azok, amelyek erősen mérgezőek a melegvérü szervezetekre, vagy a hasznos rovarokat, hasznos szervezeteket pusztítják; ezeknek a felhasználása az integrált védekezésben nem engedélyezett. $\mathrm{Az}$ integrált védekezésbe besorolt vegyszereknél valójában a szerekkel szemben esetleg kialakuló rezisztenciát is figyelembe veszik. Általában magyarországi besorolás szerint sárga jelzést kapnak, mert az évenkénti használat számát lehetőség szerint korlátozni kell. Tehát, ha túl sokat használjuk öket, akkor bizonyos rezisztencia kialakulhat velük szemben. Vannak atkaölő szerek, amelyek alkalmazását évente csak egyszer vagy kétszer javasolják. . Egyes felszívódó környezetkímélő gombaölő szerekkel szemben, a kialakuló rezisztencia kockázata elég nagy. Ezek használatát csak korlátozottan javasolják az integrált védekezés keretében -, helyettük a kontakt gombaölő szereket kell alkalmazni. Tehát a sárga jelzésű, integrált védekezésre alkalmas vegyszerek rendszerint a rezisztencia kialakulásának veszélye miatt kapnak sárga és nem zöld besorolást. A készítmény megfelelő kiválasztásán túl az alkalmazástechnika és a megfelelő időben való kijuttatás is fontos (Boller et al., 2004).

Az ökológiai gazdálkodás olyan fenntartható, változatos, kiegyenlített, környezetvédő mezőgazdasági rendszer, amely értékes élelmiszert állít elő, és egységes rendszernek tekinti a talaj-növény-állat-ember ökoszisztémát. A gazdálkodás alapelvei: minőségi élelmiszer előállítása, amelyek mentesek mesterséges szermaradványoktól; a talaj termékenységének javítása és fenntartása, a természetes ökológiai körfolyamatok megőrzése, megújuló 
energiaforrások használata; a biodiverzitás megőrzése; szintetikus szerek és génmódosított élölények és azokból származó anyagok használatának kizárása. Az ökológiai termesztési rendszerben a termesztési és növényvédelmi lehetőségek szükösebbek. A tápanyaggazdálkodásban kizárt valamennyi szintetikus tápanyagforma (pl. mütrágya), illetve kizárt valamennyi szintetikus készítmény. Alapvető célkitüzés a megelőzés és a rezisztens, illetve a tájra jellemző fajták használata, a növényállomány kondíciójának fenntartása. Az ökológiai növénytermesztésben probléma lehet az egyes növényvédőszerek fitotoxicitása (pl. rézhidroxid tartalmú készítmények). A jelenlegi magyarországi viszonylatban még nem áll rendelkezésre minden eszköz, illetve számos, a nyugat-európai országokban engedélyezett, ökológiai termesztésben használható növényvédő-szer. Ezért jelenleg ez a termesztési mód itthon még nagy kockázattal jár, és jelentősen megnő a fajtaválasztás és a növényvédelmi technika szerepe. $\mathrm{Az}$ elmúlt tíz évben fontos tényező a globális felmelegedés következtében a rendkívül szélsőséges időjárás, mellyel szemben igen nehéz védekezni és kiszolgáltatottá teszi a gazdálkodókat. Az utóbbi évek tapasztalata, hogy az éghajlati anomáliák egyre nagyobb szerepet játszanak a gyümölcsültetvények terméshozamában és a betakarított termés minőségében. Nagy és munkatársai (2009) valószínünek tartják, hogy a hazai gyümölcstermelésre nem a hőmérséklet fokozatos növekedése, hanem az extrém időjárási jelenségek gyakorisága és kiszámíthatatlansága gyakorol nagyobb hatást. Az extrém időjárási események pontosabb előrejelzése, a fák fagy-és szárazságtűrésének tesztelése fontos feladat (Soltész et al., 2006, 2008). Rodrigo (2000) szerint fontos a váratlan időjárási hatások miatt a bekövetkező tápanyag-utánpótlás a gyümölcsösökben, mivel az évelő növényeket ért hatások évek múltán is kimutathatóak és hatással vannak a terméshozamra és termésminőségre egyaránt. Ezen termesztési módnak nehézségei ellenére, a bioszféra szempontjából rendkívül fontos a tájmegtartó, biodiverzitást fokozó szerepe. Számos tanulmány vizsgálta az ökológiai gazdálkodás szerepét a heterogén élőlény populáció fenntartása szempontjából (Norton et al., 2009; Clough et al., 2005; Aude et al., 2003). A konvencionális termesztési módhoz képest, ahol hatalmas mesterséges monokultúrás gazdaságokat hoznak létre, az ökológiai gazdálkodás során fokozott tájképi komplexitást állapítottak meg madarak (Chamberlain et al., 2000; Freemark \& Dirk 2001), növények (Roschewitz et al.,2005; Gibson et al., 2007, Boutin et al., 2008) és gerinctelen élőlények esetében (Schmidt et al., 2005; Rundlof \& Smith, 2006; Holzschuh et al., 2007). Az elmúlt 15 éveben ezen termesztési mód jelentősége növekedett, hála számos megjelent tanulmánynak, valamint a média és a-, politika támogatásának, azonban még mindig elég kis piaci hányaddal - Európában csak 4\% - rendelkezik (Tomek et al., 2012). A viszonylag kis részesedés oka, egyrészt, a fogyasztók megítélése szempontjából, hogy a bioélelmiszerek megtermelése jelenleg költséges és ez emeli az árakat, másrészt a termelő 
oldaláról, hogy e forma rendkívül idő -és munkaigényes, és feltételez egy előzetes szaktudást (Offermann \& Nieberg, 2001). Az ökológiai gazdálkodással kapcsolatban számos tanulmány felveti, hogy az ilyen gazdálkodásra való áttérés ugyan fenntarthatóbbá és környezetkímélővé válik, ugyanakkor a terméshozamok visszaesésével jár (Stanhill, 1990; Nguyen et al., 1995; Ryan et al., 2004; Gunst et al., 2007; Leifeld, 2012). Az ökológiai gazdálkodás egyik legnagyobb kihívása ugyanis olyan fenntartható nagy terméshozam biztosítása, amelyből kiváló minőségü termék születik, úgy, hogy ugyanakkor összhangban vannak a természeti környezettel és nem károsítják azt kémiai szerekkel (Tilman et al., 2002). Habár ez a gazdálkodási forma rendkívül jól illeszkedik az agroökoszisztémába és potenciális környezeti előnyökkel jár - mint például a biodiverzitás esetében -, a kérdés fennáll, vajon egy ilyen rendszer hogyan lesz képes 2050-re az előreláthatólag 9 milliárdra duzzadó népesség számára elegendő élelmiszert termelni, amikorra csak a globális gabona-igény a kétszeresére fog nőni (Murphy et al.,, 2007). A felvetett problémák ellenére ennek a formának is egyre inkább van és lesz létjogosultsága a mủvelési rendszerek körében. A Föld országaiban jelenleg 0,1-17\%-ban folyik ökológiai termesztés. Az ökológiai gazdálkodás részaránya (megmüvelt terület százalékában) a legnagyobb Liechtensteinben (17\%), Ausztriában (11,3\%), Svájcban (9,8\%), Olaszországban (7,9\%), Finnországban (6,6\%), Dániában (6,5\%) és Svédországban (6,3\%) (Holb, 2005). A világpiaci részesedésnek jelentős lökést adhat, ha számos nagykereskedő cég felveszi termékpalettája közé ezeket a termékeket. Hazánkban az a sajnálatos helyzet, hogy az itt megtermelt biogyümölcsök (elsősorban alma, körte, meggy) kb. 90\%-a külföldön kerül értékesítésre, pedig a hazai biogyümölcsök, e fent említett három gyümölcsfajta esetében rendkívül jó minőségüek, és mint a dolgozat további eredményei is mutatják, alig mérhető szignifikáns különbség az integrált termesztési módhoz képest. Az alacsony itthoni kereslet oka, hogy rendkívül drága az itthoni biogyümölcs, a kereskedők a beszerzési árnál akár 5-10szer drágábban adják el a terméket (Kenyeres, 2009). Az ökológiai gazdálkodás tekintetében az egyes térségekben - hazánkban is - eltérőek a feltételek. Fontos ismerni a területi tényezőket, illetve az őshonos fajtákból szelektált rezisztens fajtákat. Világviszonylatban, és Európában is, az alma, körte és szőlő részaránya a legmagasabb a biotermesztésben. Részarányát tekintve a következő fontos csoport a csonthéjasok - meggy, cseresznye, kajszi, őszi, szilva (Balázs, 1997). 


\subsection{A vizsgált gyümölcsök ökológiai növényvédelme}

\section{MEGGY és CSERESZNYE}

A meggy és cseresznye ökológiai termesztési technológiájában a legfontosabb növénybetegségek közé soroljuk a cseresznye és a meggy blumeriellás levélfoltosságát (Blumeriella jaapii), a csonthéjasok moníliáját (Monilinia laxa), a sztigminás levéllikasztó betegséget (Stigmina carpophyla), valamint az agrobaktériumos gyökérgolyvát (Agrobacterium tumefaciens) (Holb, 2005). A blumeriellás levélfoltosság esetén el kell távolítani a leveleket és megsemmisíteni. Ökológiai termesztésben réztartalmú lemosópermetet lehet használni. Monília a csonthéjasok egyik legveszélyesebb betegsége, amely a fiatal ágak elhalását idézi elő. Itt is fontos a fertőzési forrás eltávolítása. A biológiai védekezés lehetőségének vizsgálata során több antagonista fajt izoláltak, az egyik ilyen az Epicoccum nigrum (Larena, et al., 2003). Fontos a rovarkártevők elleni védekezés (cseresznyelégy), amelyet még a rügypattanás elött érdemes elkezdeni, réztartalmú lemosó permettel. A Pándy típusú meggyek különösen érzékenyek a moníliára (Paszternák et al., 1982). A Pipacs típusú meggyfajták bizonyos fokú ellenállóságot mutatnak (Holb, 2005). A Csengődi meggy nagyfokú rezisztenciával bír, ezért javasolható ökológiai termesztésben. Az állati kártevők közül a cseresznyelégy elleni biológiai védekezés a tojásrakást gátló fermon csapdák kihelyezése.

A dolgozatban vizsgált gyümölcsök sikeres ökológiai növényvédelmi technológiájának az alapja a növényvédelmi eljárások komplex alkalmazása, tehát, hogy minél többoldalúan lépjünk fel a károsító tényezőkkel szemben. A hagyományos és integrált technológiákkal ellentétben a mechanikai-agrotechnikai-, és biológiai védekezésre alapozhatunk. Habár ezek az eljárások, szerényebb hatékonyságúak és munkaigényesebbek, komplexebbek és tájfenntartó hatásuk sokkal jobban belesimul a természetes ökoszisztémába. Ugyanakkor fontos a rezisztens illetve tájszelekcióval kiválogatott fajtahasználat mellett, a természetes ellenségek folyamatos szaporodásának az elősegítése. Fontos a szegélynövények telepítése, amelyek segítségével ki fog alakulni az a mikro-bioszféra az ültetvényben, amelyben rendelkezésre állnak azok a hasznos rovarok, pókok, kétéltủek, madarak, amelyek elpusztítják a kártevőket. Törekedni kell a biológiai sokszínüség kialakítására és fenntartására. Ha hiányoznak, akkor hagyományos permetezőszerek bevonása nélkül sérülékenyebb lesz az ültetvényünk. Mind az alma és a körte (M2. melléklet 17. ábra), mind a meggy és a cseresznye (M2. melléklet 16-17. táblázat) esetében rendelkezésre állnak az ökológiai termesztésben is használható komplex ökológiai növényvédelmi technológiák. 
$\mathrm{Az}$ alma és körte termesztése során a legfontosabb növénybetegségek közé a tüzelhalást (Erwinia amylovora), az almafalisztharmatot (Podosphaera leucotricha), és-, az alma venturiás varasodását (Venturia inaequalis) soroljuk. Az állati kártevők közül a technológia szempontjából a legjelentősebbek a cserebogárpajorok (pl. Melolontha melolontha), az almamoly (Cydia pomonella), a körtemoly (Cydia pyrivora), a sodrómolyok és az aknázómolyok, illetve a levéltetvek (Holb, 2005). Az almalisztharmattal szembeni legjobb védekezés a betegséggel szemben ellenálló fajta, mivel a fogékony fajták esetében az ökológiai termesztésben nehéz a növény védelme. Ma már elérhetők olyan fajták, amelyek komplex rezisztenciával rendelkeznek, és a varrasdáson kívül a lisztharmattal és tüzelhalással szemben is rezisztensek. Az így nemesített fajták már elsősorban ökológiai termesztésre javasoltak. A körte venturiás varasodása (Venturia pyrina) esetén, csakúgy, mint az almánál, szükséges a levelek összegyüjtése és elégetése, de a körténél még ez sem hoz biztosan eredményt. Az alma moníliás gyümölcsrothadással szembeni védekezésnél viszont előtérbe kerülnek az agrotechnikai eljárások. A lehullott beteg gyümölcsök eltávolítása, illetve a még fán lévőknek az eltávolítása a metszés során, célravezető eljárás (Leeuwen et al., 2002). A tűzelhalást először 1995-ben Nyárlőrincen írták le (Hevesi et al., 2009). A legtöbb fertőzés az almán, körtén és a birsen fordult elő. Agrotechnikai védekezéssel kivédhető, ha gondosan választjuk meg a termőhelyet és kerüljük a kötött talajú, rossz vízgazdálkodású területeket. Ha már kialakult, akkor a fertőzött részeket el kell távolítani. Biológiai védekezése ígéretes kutatási területnek számít napjainkban. Hazánkban kereskedelmi forgalomban kapható egy élesztőszerü gombafaj (Aureobasidium pullulans), amely a kinyílt virágokon elszaporodik és lehetetlenné teszi a kórokozó baktérium fertőzését (Hevesi et al., 2009). A lisztharmat ellen alkalmazott, leginkább ismert parazita az Ampelomyces quisqualis. Több ilyen biológiai preparátumot tartalmazó készítményt hoztak forgalomba. A venturiás varasodás ellen mészkőporral vagy agyagásványokkal jó eredményt lehet elérni, de napjainkban a varasodás elleni ökológiai védekezés alapja a réz- és kénvegyületek alkalmazása. Nyugat-Európában már igyekeznek ezeket mellőzni, és egyéb módszereket alkalmaznak. A kártevők elleni védekezésben például a molyok ellen segítség az egyedszámuk csökkentése konfúziós technikával és a farakások távol tartásával az ültetvénytől. $\mathrm{Az}$ almamoly elleni biológiai védekezés alapja a szexferomon (E,E-8,10-dodecadien-1-ol) csapdák telepítése, amelyek kereskedelmi forgalomban is kaphatók, illetve a Bacillus thuringiensis tartalmú készítmények. Feromon csapda alkalmazható a törpemoly illetve az aknázómoly esetében. A tűzelhalás elleni biológiai védekezés ellen több élő szervezetet izoláltak, egyik ilyen a Pseudomonas fluorescens (Lindow et al., 1996). 


\subsection{A gyümölcsök biológiailag aktív vegyületei}

\subsubsection{Polifenolok}

A polifenolok a növényi metabolizmus szekunder termékei, elsődlegesen a növényi sejt védelmét látják el a különböző külső károsító tényezőkkel szemben. A növényvilágban valamennyi szervben megtalálhatók (Santos-Buelga \& Williamson, 2004) és alapvető fontosságúak táplálkozás-élettani szempontból, antioxidáns tulajdonságuknak köszönhetően (Aberoumand \& Dekoule 2008). A növényi eredetü élelmiszerekben, zöldségekben, gyümölcsökben és levekben a polifenolok megtalálhatók. Napjaink egyik legnépszerübb, élelmiszerekkel és táplálkozás-élettannal kapcsolatos kutatási területét jelentik. Polifenol vizsgálatok folynak, többek között, az úgynevezett francia paradoxonként ismert, rezveratroltartalomra visszavezetett borfogyasztás vs. szív- és koszorúér betegség vizsgálatokban (Liu et al., 2007; Abdulla \& Badaway, 2001; Ferrieres, 2004), a zöld teáknak tulajdonított egészségvédő hatásban (Henning et al., 2004) és, a bogyós gyümölcsök fogyasztásának ösztönzésében (Balogh, 2010; Wu et al., 2004). A polifenolok ugyanakkor analitikai szempontból egy meglehetősen inhomogén, több ezer vegyületet magába foglaló csoportot jelentenek, amelyet a következő tulajdonságokkal lehet körülhatárolni: (1) növényi eredet /zöldségek, gyümölcsök, gyógynövények/, (2) többnyire vízben jól oldódó komponensek, (3) antioxidáns tulajdonságúak, (4) legalább egy fenolos hidroxil-csoport vagy annak származéka jellemzi őket (Abrankó et al., 2010). Harborne (1989) a polifenolos vegyületeket kémiai szerkezetük alapján 10 csoportra osztotta (2. ábra). A különböző polifenolok közül a flavonoidok fontos szerepet töltenek be táplálkozás-élettani szempontból jótékony hatásuknak köszönhetően. Antioxidáns hatásuk mellett antibakteriális, antivirális, anti-karcinogén és gyulladáscsökkentő hatással rendelkeznek (Shahidi \& Naczk, 1995; Breinholt, 1999; Duthie, 2000 ). A flavonoidok további 13 alcsoportra oszthatóak (3. ábra) (Halborne, 1993).

Mivel a polifenol-tartalmú minták nem egyetlen típusú polifenolos vegyületet, hanem többnyire azok keverékét hordozzák, az úgynevezett ,,polifenol profil””, tehát a különféle polifenolok mennyiségének és egymáshoz viszonyított arányának meghatározása, lehetőséget nyújt olyan összetett és bonyolult vizsgálatok elvégzésére, mint például eredetmeghatározás, élelmiszerhamisítás kimutatására, vagy az élelmiszerek gyümölcstartalmának megállapítása (Papp et al., 2010). 


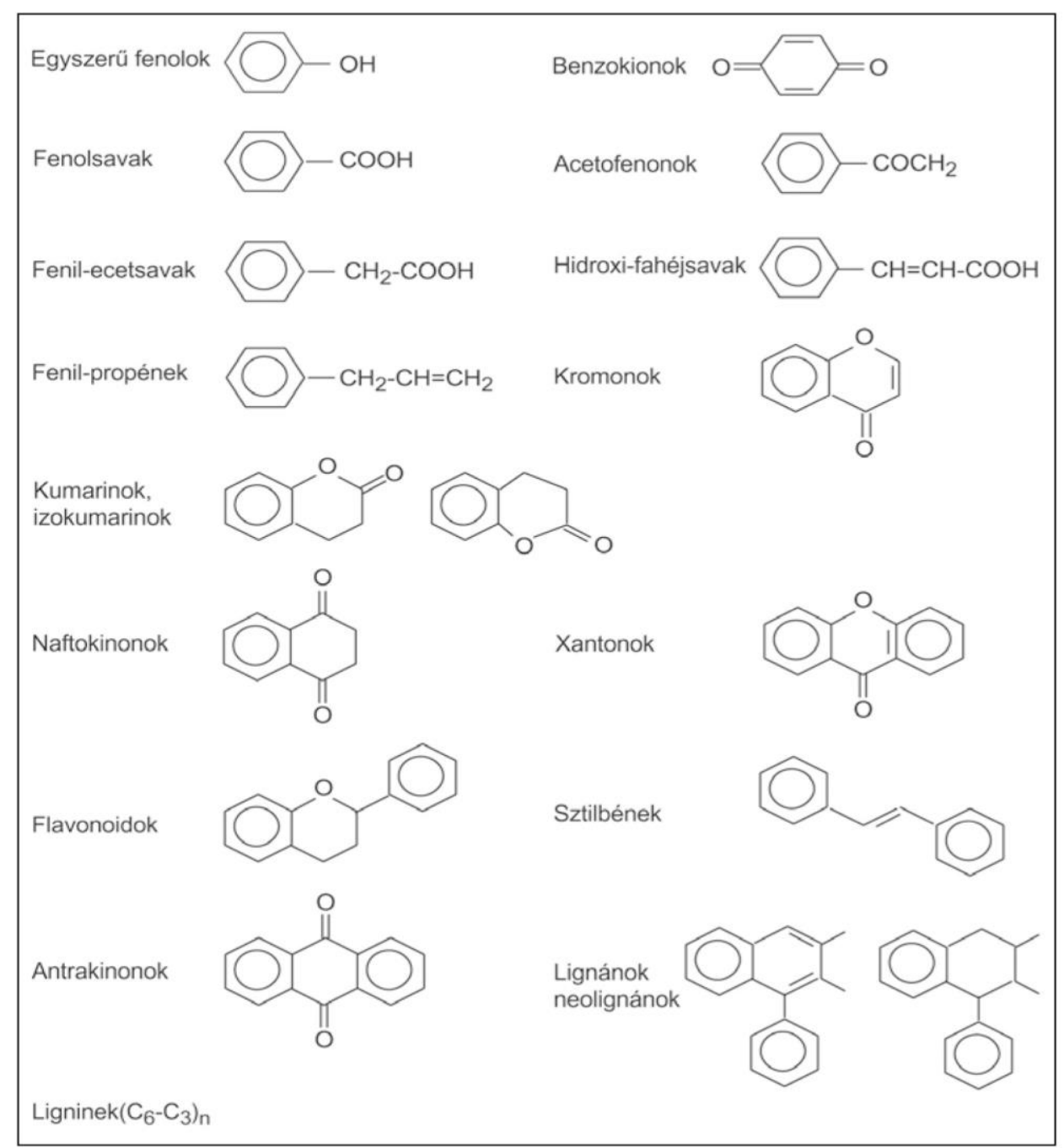

2. ábra: Polifenolos vegyületek csoportjai (Halborne, 1989)

A polifenolok egymás melletti minőségi és mennyiségi mérése azonban nagyon költséges folyamat, beleértve mind a standard polifenol vegyületek beszerzését, mind pedig a szinte kötelezően alkalmazandó, megfelelő szelektivitást biztosító HPLC-ESI-MS csatolt rendszer alkalmazását. Ugyanakkor szükség van egy olyan módszerre is, amely költséghatékony módon, robusztus müszerre építve biztosítja az összes polifenolos vegyület együttes mérését és a minták összehasonlítását.

A polifenolokban szerkezetüktöl függetlenül közös, hogy antioxidáns hatásúak, tehát oxidálószerrel reagáltathatók. Ez azt jelenti, hogy a mintából történő „szelektív” extrakciójukat követően (ami a vízben való oldódásukra utal), nyomon követhető és sztöchiometriailag kézben tartott redox folyamatban az összes vegyület részt vesz és a minták összevetésére alkalmas eredményt szolgáltat - röviden ez az alapelve az úgynevezett összes polifenol-tartalom meghatározásnak (Abrankó et al., 2010). 


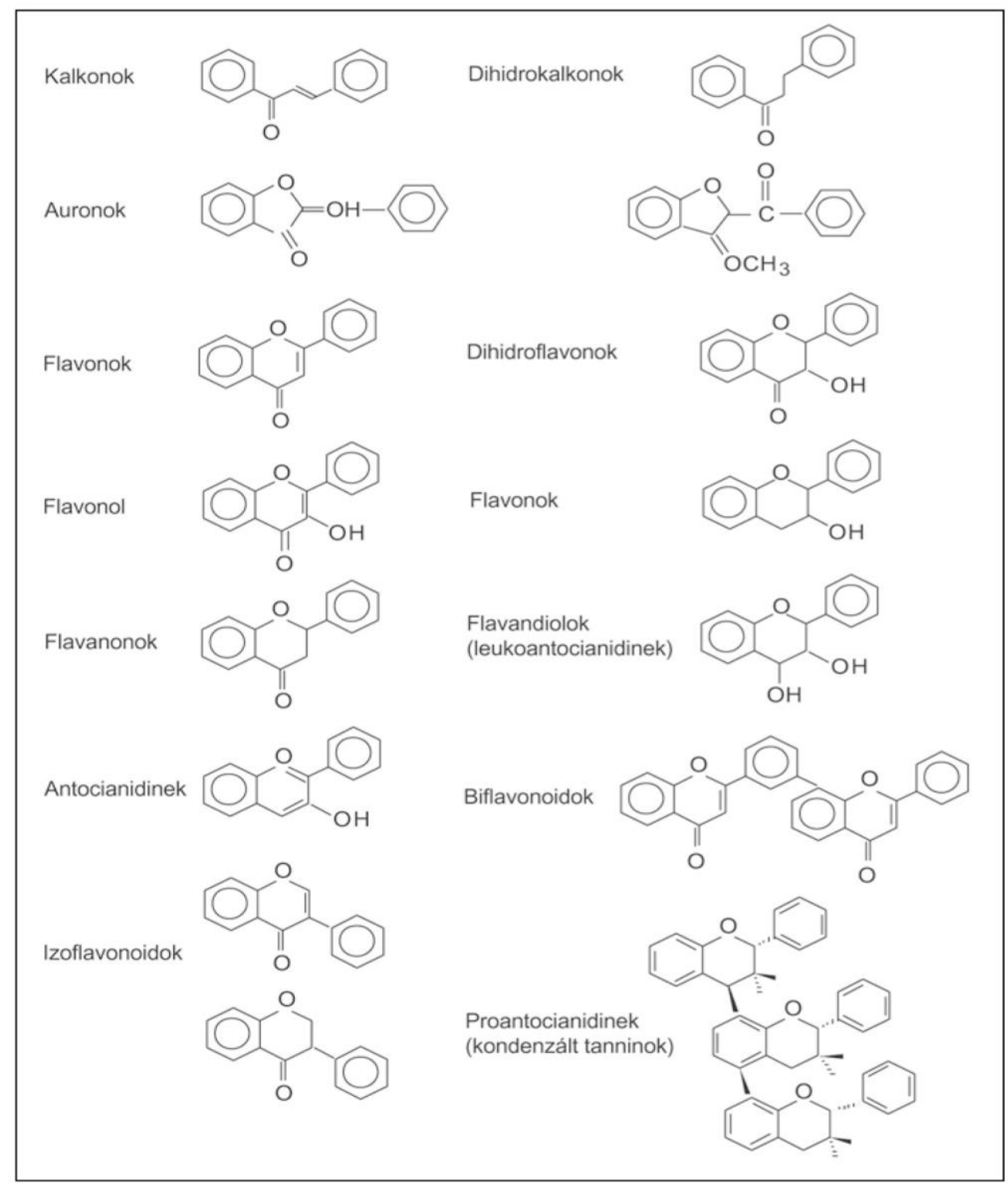

3. ábra: Flavonoidok alcsoportjai (Halborne, 1993)

A dolgozat egyik vizsgálati tárgyát képező polifenol komponens, az antocianinok, a Halborne (1993) szerinti csoportosításban az egyik flavonoid alcsoportot képezik (3. ábra). Kémiai szerkezetüket tekintve oxigéntartalmú hetrociklikus (2 fenil-benzo-pirillum) vegyületek (Wrolstad et al., 2005). Fontosabb alcsoportjai a gyürükön található hidroxilcsoportok száma szerint képezhetőek (pelargonidinek, cianidinek és delfinidek). A hidroxilcsoportok számának növekedésével a kék színárnyalat erősödik (pelargonidin, cianidin, delfinidin), míg a metoxi csoportok számának növekedése a piros színárnyalatot erősíti (peonidin, petunidin, malvidin) (Gombkötő \& Sajgó, 1985). 
A felsorolt vegyületeknek köszönhető a bogyós gyümölcsök sötét, vöröses-kékes, a cékla és meggy bordó és, a padlizsán mélylila színe (Slimestad és Solheim, 2002; Pantelidis et al., 2007).

$\mathrm{Az}$ antociánok kimondottan pH-érzékeny vegyületek. A pH-növekedés hatására az enyhén lúgos tartományba érve a pirosból kékes árnyalatúvá változik színük (Castaneda-Ovando et al., 2009).

Táplálkozás-élettani szempontból számos kedvező tulajdonsággal rendelkeznek. Képesek megelőzni a kardiovaszkuláris betegségeket (Silaste et al., 2007) és a daganatos betegségeket (Grieb et al., 2009, Zhang et al., 2009, Fernandes et al., 2013).

Növényélettani szempontból az antocián pigmentek nagy segítséget jelentenek azon növények számára, amelyek a rovarok segítségét használják beporzáshoz, valamint az antociánt tartalmazó gyümölcsöket az állatok nagyobb valószínüséggel találják meg, a magok jobb szétszórását biztosítva. A fotoszintézist ellátó szövetek esetében az antocián pigmentek védelmet nyújtanak a napsugárzás káros hatásai ellen, ezáltal védve a létfontosságú szöveteket. Ennek eredményeként a növények fiatal hajtásai pirosak, vagy rozsdaszínủek, a lombhullatók őszi levelei sárgásbarnák lesznek, valamint a széleslevelü örökzöldeknél a téli időszak alatt a levelek pirosas árnyalatúvá válnak.

A polifenol vegyületek egyik, fontos tulajdonsága az antioxidáns kapacitása vagyis, hogy képes megvédeni az emberi szervezetet a reaktív oxigén gyököktöl. Az aerob anyagcserét folytató élőlények - köztük az ember - esetében energiatermelő folyamatai során erőteljes oxidatív tulajdonságú vegyületek, más néven reaktív oxigén fajták keletkeznek (Asmus \& Bonifacic, 2000). Ezek a vegyületek, habár természetes folyamatok részeként keletkeznek, veszélyesek a szervezetre. Olyan kémiailag reaktív oxigén-, nitrogén-, kén- vagy szénközpontú molekulák, amelyek külső elektron héjukon párosítatlan elektront tartalmaznak, amelyek nagy reakció kézségüek. Gyorsan reakcióba lépnek, jelenlétük oxidatív stressz állapotot idéz elő (Cadenas, 1989). A polifenol vegyületek antioxidáns hatása abban rejlik, hogy képesek befogni a szabadgyököket, azáltal hogy a konjugált $\pi$-elektron rendszer miatt, képesek hidrogén atomot, elektron vagy kelát fém kationokat átadni a hidroxil csoportokról a reaktív szabad gyököknek, ezáltal semlegesítve azokat (Amarowicz et al., 2004). Az antioxidáns hatékonyság mértéke és a reakció kinetikája szerint az egyes polifenol komponensek nagy eltéréseket mutatnak, attól függően, hogy mennyi és milyen pozíciójú hidroxil gyök áll rendelkezésre. Az antioxidáns kapacitás nő a hidroxilezés mértékével, mint például a trihidroxilált galluszsav esetében, melynek magas az antioxidáns kapacitása (Rice-Evans, 1996). A polifenol tartalom és az antioxidáns hatás között Lugasi (2004) szoros összefüggést állapított meg. A gyümölcslevek jelentősebb antioxidáns hatást képesek kifejteni, mint a zöldségekből nyert levek. Jelentős 
antioxidáns hatásúak a nagy antocián-tartalmú növényekből nyert levek, mint amilyen a bodza, kékszőlő, ribizke (Lugasi, 2004). Továbbá igazolt az alma, szilva és cseresznye fogyasztásának az érrendszeri-és daganatos betegségek kialakulási kockázatának csökkentésében játszott kedvező szerepe (Kang et al., 2003), mely az antioxidáns kapacitással hozható szoros összefüggésbe. Az antioxidáns kapacitás gyümölcsfajonként eltérő, de ez sok esetben igaz a fajták között megmutatkozó eltérésekre is (Scalzo et al., 2005). Ez adódhat az egyes fajták közötti különbségekből, illetve az eltérő termesztéstechnológiai körülményekből is (Caruso \& Liverani, 1996; Scalzo et al., 2005).

\subsubsection{Szerves savak}

A gyümölcsökben előforduló savak (almasav, citromsav, borkősav) a nem illó savak közé tartoznak (Lásztity, 1981). Az almatermésüekre és a csonthéjasokra az almasav, a bogyósokra és a déli gyümölcsökre a citromsav, a szőlőre a borkősav jelenléte jellemző. A borostyánsav és a csersav csak nyomokban lelhető fel bennük. A gyümölcsökben lévő szerves savak az anyagcsere-folyamatok intermedierjeiként keletkeznek a gyümölcsben. Hatásuk van a növekedésre, érésre és öregedésre. A gyümölcslevek alacsony $\mathrm{pH}$-ját a magas szervessavtartalom okozza, mely az őszibarack $(0,15-0,5 \%)$ esetében a legkisebb és a citrom $(4,5-6,3 \%)$ esetén a legnagyobb. A szerves savak gátló hatással vannak a mikrobák növekedésére, ezért szerepük van a gyümölcsminőség megőrzésében. A szerves savak jelentős mértékben hozzájárulnak a gyümölcs ízérzetének kialakításához, továbbá a friss, savanykás íz fenntartásához (James, 1985).

\subsection{Növényi eredetü élelmiszerek mikrobiális szennyezettsége}

A növények, így a gyümölcsök is természetes körülmények között hordoznak egy apatogén, epifita mikrobiotát. A gyümölcsök a mikroorganizmusokkal elsődlegesen a termesztés során a talajból és a környezetből szennyeződhetnek - ez adja a természetes mikrobiotát, másodlagosan pedig a szedés és az azt követő szállítás, tárolás és feldolgozás. A mikrobák jelen lehetnek csupán szennyezőként, de némelyik mikroorganizmus képes a gyümölcs romlását is okozni, vagy veszélyt jelenthet a fogyasztó számára. Ilyenek a kórokozó mikrobák vagy toxintermelö penészgombák (Beczner \& Bata-Vidács, 2009). Az epifita mikrobiotában a baktériumok zömét a Pseudomonas csoportba és/vagy az Enterobacteriaceae csoportba tartozó Gram-negatív baktériumok alkotják. Ezen baktériumok nagy része nem humán kórokozó. A mikrobák száma függ az évszaktól és az időjárástól, általában grammonként $10^{3}-10^{8}$ sejt között detektálható. A 
gyümölcsök természetes mikrobiotáját alkotó élesztők és penészgombák jelenléte elsősorban a gyümölcsök kémiai összetételével (egyszerü cukrok, szerves savak) és kis pH-jával magyarázható (a megfelelö érettségü alma pH-ja 3,1 és 3,5 között van). A mikrobás romlási hajlam és a gyümölcsök érettségi állapota között is szoros összefüggés van. Az érési folyamatok során a gyümölcsök pektin anyagainak enzimes átalakulása következtében a legtöbb gyümölcsszövet veszít szilárdságából, és az érés elörehaladtával csökken a gyümölcsök kémiai eredetü ellenállóképessége. A gyümölcsromlás elindítói főként penészek és élesztők, ezért vizsgálatuk fontos. A legfőbb veszélyforrást a tárolás során bekövetkező romlások jelentik. Általában a mechanikailag sérült, puha növényi részeken indul meg a romlás, amely azután átterjed az ép növényi részekre is. A gyümölcsök romlását okozó leggyakoribb penészgombák almaféléken és csonthéjasoknál: az ún. „barna rothadás” okozói - a Monilia, Sclerotinia fajok. A Monilia fructigena növénypatogén gomba, már a fán megtámadja a termést. A megtámadott részek puhák, kezdetben világos, majd sötétbarna színủek. Sclerotiniás fertőzés esetén a héj beszárad, bőrszerüvé válik. Mindkét esetben az egész gyümölcsre és a környező ép gyümölcsökre is átterjed a romlás. A „zöld rothadás”-t, Penicillium expansum vagy más Penicillium fajok okozzák. Almaféléknél gyakori, a héj barna elszíneződésével kezdődik, majd a megpuhult gyümölcshúsból előtör a szürkésfehér, majd kékeszöld „penészpárna”. A romlott foltok könnyen kinyomhatók az ép szövetekböl. Ez a romlás csak hosszabb tárolás után szokott jelentkezni. Különös gondot kell fordítani elkerülésére, mivel a $P$. expansum bizonyos körülmények között mikotoxin termelésre hajlamos (patulin). A „szürkepenészes rothadás” a Botrytis cinerea által okozott elváltozás, már termesztés közben fertőzheti főleg a bogyósokat (szőlö). Bevonja a gyümölcsöt hifaszálaival és kiszívja a nedvességet, ezáltal összetöppedt, betöményedett terméseket kapunk (kedvező időjárási viszonyoknál ez a szőlő aszúsodását okozza). Alternaria fajok okozta rothadások: főleg almaféléken, először sötétbarna, majd fekete egyre növekvő foltok a héjon, alatta a gyümölcshús szivacsossá „mumifikálódik”. A különböző magházrothadásokat a Fusarium, Alternaria, Rhizopus, Phytophtora és az Aspergillus nemzetség tagjai okozhatják. A termés magházában fejlődnek ki a micéliumok, amely csak felvágáskor válik láthatóvá. Chand-Goyal és Spotts (1997) tanulmányában alma és körte epifita baktérium és élesztőgomba biótáját vizsgálta és Golden Delicious alma esetében $10^{3}-10^{4}$ mikroba/g közötti értékeket, míg körte esetében $10^{3}$ mikroba/g körüli értékeket detektált, valamint körte felületéröl a következő élesztőgombákat izolálta Rhodotula glutinis-t, Cryptococcus albidus-t, Debaryomyces hanseneii-t.

Táplálkozáskutatások eredményeképpen világszerte megnőtt a friss vagy konyhakész zöldségek és gyümölcsök fogyasztása. A fogyasztói társadalom részéről megnövekedett az igény az ilyen 
jellegű élelmiszerek iránt, ezért a piac e termékek széles skáláját kínálja. Ezzel egyidőben fokozatosan nőtt az élelmiszerek romlását okozó patogén vagy apatogén mikrobák által okozott megbetegedések száma, melyeket friss zöldségek vagy gyümölcsök elfogyasztása okozott (Gutierrez,1997; DeRoeyer, 1998; Beuchat, 2002; Buck et al., 2003; Nygård et al., 2004; Söderström et al., 2005; Mukherjee et al., 2006; Emberland et al., 2007; Pezzoli et al., 2007; Abadias et al., 2008; Beczner \& Bata-Vidács, 2009). Ilyen európai méretü példa a 2011-es német élelmiszerbotrány, amelyet valószínüleg fertőzött növényi csíra okozott, és amelyben 46an haltak meg és több mint 3000 megbetegedést regisztráltak. A járvány kórokozója egy olyan Escherichia coli baktérium volt, mely alapvetöen az E. coli patocsoportok enteroaggregatív csoportjába tartozik, de a toxintermelő tulajdonságát egy EHEC patocsoportba tartozó baktériumtól vette át. Az O104:H4 szerotípusú baktérium 2-es típusú Shiga toxint termel, a baktériumsejtek halmazai tapadnak a bélfalhoz, és a baktérium többféle antibiotikummal szemben rezisztens (multirezisztens) (Herpay et al., 2011). Az utóbbi évtizedben megszaporodott esetek miatt élelmiszerbiztonsági szempontból az egyes patogén mikrobák vizsgálata is fontossá vált növényi eredetü élelmiszerek esetében. Annak ellenére, hogy számos tanulmány készült az egyes élelmiszerek mikrobiológiai szennyezettségéről (Johannessen et al., 2002; Johnston et al., 2005; Mukherjee et al., 2004, 2006), még mindig kevés információ áll rendelkezésre a friss zöldségek és gyümölcsök patogén szennyezettségéről, illetve annak pontos okairól (Tournas, 2005; Tournas et al., 2006). A különböző zöldségek és gyümölcsök a termesztés és különböző feldolgozó folyamatok során számos elemmel érintkeznek, amik mind a patogén mikrobák közvetítői lehetnek (Beuchat, 1996; Beuchat \& Ryu, 1997). Wells és Butterfield (1997) szalmonella szennyezettséget írt le friss gyümölcsökön és zöldségeken. Janisiewicz és munkatársai (1999) a gyümölcsre rászálló gyümölcslegyek E. coli fertőzöttségét állapították meg, amely lehetséges hordozó vektora lehet a baktériumnak. Az élelmiszer-eredetű megbetegedést okozó patogén mikrobák - Bacillus, Clostridium, Listeria, Salmonella, és Campylobacter spp.- természetes előfordulási helye lehet a termőtalaj, és képesek ott tartósan megtelepedni a környezeti feltételek függvényében, beleértve a tápanyag ellátottságot is (Avery et al., 2005; Nicholson et al., 2005). Az egyes baktériumok a talajban különálló sejtekként vagy a talaj részecskéihez tapadva találhatók és a fő közvetítő eszköz a víz (Tyrrel \& Quinton, 2003).

Ökológiai gazdálkodás követelményeivel megegyező otthoni kiskertből származó saláta, spenót, zeller, málna, ribizli és eper felületi mikrobás szennyezettségét is vizsgálták. Trágyázás hatására 1-2 nagyságrenddel megnövekedett a mikrobiális szennyezettség, valószínűleg a mikrobáknak növekedéséhez is optimális ásványi anyag többlet következményeként. Esős időszak után szignifikánsan alacsonyabb penész- és, élesztőgomba, illetve Bacillus szennyezettség volt megállapítható. Eper felületén különböző mikrobiális szennyezettséget - 
Enterobacter, E. coli, kóliformok, Pseudomonas aeruginosa-detektáltak. A teljes penész- és élesztőgomba szám szignifikánsan csökkent három napos hűtőtárolás után (Batáné Vidács et al., 2005). A szüret utáni biológiai védekezést vizsgálták Wojciech és munkatársai (2002) alma esetében, ahol két kereskedelmi forgalomban kapható biofungicid csökkentette a tárolás közbeni kék-és szürke-penészesedés arányát.

Az Enterobacteriaceae családba tartozó Gram-negatív Cronobacter sakazakii (2007 előtti neve Enterobacter sakazakii) baktérium, melynek további hat alfaját írták le, opportunista patogén mikroorganizmus (Healy et al., 2010). A baktériumot először tejalapú bébiételben írták le és azonosították. Azóta rengeteg környezeti és humán előfordulási helyen is azonosították (Joseph et al., 2012), ezért vizsgálata fontos, mert megbetegedést okozhat legyengült szervezetekben.

A felületi mikrobás szennyezettségre hatással van az adott minta állapota, mint belső tényező illetve (1. táblázat), a külső paraméterek, melyek az időjárást befolyásoló paraméterekből állnak össze.

1. táblázat: Az élelmiszerekben levő mikrobákra ható külső és belső tényezők és (kékkel) mikrobák müködéséhez szükséges optimális értékeik

\section{Belsö paraméterek}

$\mathrm{pH}: 5,5-8,5$

Szabadvíz tartalom (vízaktivitás) baktériumok: 0.91 , élesztőgombák: 0,88 , penészgombák: 0,8

red-ox potenciál: aerobok $>50 \mathrm{mV}$, anaerobok: $<50 \mathrm{mV}$

tápanyag tartalom: A mikrobiális szaporodáshoz optimális érték $\mathrm{C}: \mathrm{N}: \mathrm{P}=120: 10: 1$

mikroba ellenes elemek jelenléte (lysosim): gátolja az egyes mikrobák szaporodását.

biológiai és fizikai szerkezet: fizikai szerkezetben (gyümölcshúsban) lévő sérülés táptalajt ad a mikrobáknak.

\section{Külsö paraméterek}

Hőmérséklet: $15-45^{\circ} \mathrm{C}$

relatív nedvességtartalom (ERP): a tárolás folyamán, a gyümölcs-szöveti légzés során keletkező és lecsapódó víz a mikrobás romlást elősegíti

levegö

összetétele (gáz): oxigénkoncentráció: aerobok > 10\%, anaerobok $<1 \%$

Időjárás: a túlságosan szélsőséges időjárás csökkenti a mikrobaszámot. Sokáig tartó nedves, párás, de nem viharos időjárás növeli a penész-és élesztőgomba számot. 
Az epifita mikrobák vizsgálatán túl fontos az ún. indikátor vagy jelző mikrobiota vizsgálata, amely a már fent említett $E$. coli-t, kóliformokat, enterobaktériumokat foglalja magában, illetve tágabb értelemben az általános szennyezettséget jelző aerob összcsíraszám, penész-és élesztőgomba szám is ide tartozhat. Ha az aerob összcsíraszám a gyümölcsre jellemző átlagnál (pl. $10^{6}-10^{9} \mathrm{sejt} / \mathrm{g}$ ) magasabb, gyanakodni lehet fekáliás eredetű vagy higiéniai szennyezettséget jelző mikrobacsoportok előfordulására. Az Enterobacteriaceae családba Gram-negatív, rövid pálca alakú, körkörös csillókkal rendelkező mikroorganizmusok tartoznak és vizsgálatukkal egyidejüleg érdemes vizsgálni a laktózt nem erjesztő bélbaktériumok (Salmonella spp.) előfordulását is egy adott mintában. Az indikátor mikrobák vizsgálata mindamellet, hogy jelzi a nyersanyag mikrobiológiai-higiéniai minőségét, magas mikrobaszám esetén utalhat veszélyes patogén mikrobák (Salmonella spp., Listeria monocytogenes, E. coli, Enterobacter sakazakii) jelenlétére.

Granado és munkatársai (2008) integrált és ökológiai termesztésből származó almák mikrobiológiai profilját hasonlították össze. Ennek során megállapították, hogy hatféle élesztőgomba (ún. „fehér” és „,rózsaszín”), élesztőszerü gomba (Aureobasidium pullulans) és 21 féle fonalasgomba dominált az epifita mikrobiotában. Az ökológiai termesztésű minták esetében szignifikánsan magasabb penész- és, élesztő gomba számot és magasabb faji diverzitást írtak le. A Penicillium és Alternaria fajok tekintetében nem volt különbség a két termesztési mód között. A tanulmányban utalnak rá, hogy mivel a növényeket körülvevő környezet az epifita mikrobióta elsődleges forrása, ezért a termesztési mód meghatározhatja a mikrobiota milyenségét. A szintetikus fungicid anyagok használata különbözö, illetve az integrált termesztési módnál szegényesebb, és kisebb számú mikroba populációt eredményez. Ezen kívül a mikroklíma, a földrajzi helyre jellemző mikrobiota eredményezhet még különbségeket. A vizsgálatban számos faj leginkább csak ökológiai (Microsphaeropsis olivacea, Cladosporium gloeosporioides, Phoma sp., steril „,coelomycetes”), illetve integrált termesztési módnál volt jellemző (Botrytis cinerea, Trichoderma sp., Cytospora sp., Phialophora sp., Stemphilium sp.). Az ökológiai termesztésnél leírt nagyobb élesztö- és penészgomba fajdiverzitás szerepet játszik a patogén gombák kiszorításában.

Csernus és munkatársai (2013) különböző fajta almák (Bőrkormos renet, Florina, Jonagold, Golden Reinders, Produkta) felületi penészgomba szennyezettségét vizsgálták két évjáratban. Összesen 34 féle penész előfordulását mutatták ki, melyek többsége a Penicullium nemzetséghez tartozik, továbbá jellemző volt még Aspergillus, Cladosporium és Alternaria nemzetség előfordulása a megvizsgált mintákon. 


\subsection{A gyümölcsök érése és romlási folyamata}

A szürethez vezető gyümölcs fejlődési szakasz: a növekedés, a fejlődés, az érés illetve utóérés fajonként és fajtánként változik. Sem a biokémiai-élettani változások, sem az érés előtti illetve alatti növekedés mértéke nem egyforma. Míg az almatermésüekre az egyszerü szigmoid, a csonthéjasokra a kettős szigmoid növekedés jellemző. A sejtosztódási szakaszokat nagyrészt a citokininek, a megnyúlásit az auxinok szabályozzák. Érés előtt megnőnek a sejtek közötti járatok, a vakuolumok, ami méréseink szerint oda vezet, hogy pl. a Jonathan alma tömege hazánkban sokévi átlag szerint szeptember 5. és 25. között napi 10\%-kal gyarapodik. Többek között ez a tény (kb. 5-6 t/ha terméstöbblet) sem indokolja a szüret korai megkezdését. A korábban szedett gyümölcsöknek még nem alakul ki a megfelelö alap- és fedőszíne sem. Almatermesztésben arra, hogy a zöldből pirosra változzon a héj színe, jó hatásúak a rendszerint később jelentkező hidegebb éjszakák is (Soltész, 2005).

Érés előtt változik meg a szénhidrát (cellulóz, pektin) összetétel is, többek között a pektinmetilészteráz vagy a poligalakturonáz enzimek közremüködésével. A keményítő mennyisége a hidrolízis miatt csökken, a cukrok felszaporodnak, megváltozik a sav mennyisége, ennek következtében a cukor/sav arány is. Ez utóbbi némelyik gyümölcsre nagyon jellemző lehet. Almánál érésjelző mutatóként is használják, illetve meghatározza a gyümölcsök ízharmóniáját (Hecke et al., 2006). A gyümölcsök aroma és illóanyag komponensei is (alkoholok, észterek, aldehidek stb.) ebben a szakaszban kezdenek kialakulni. Az érés során csökken a klorofilltartalom és nő az antioxidáns színanyagok, antocianinok, karotinoidok bioszintézise (Treutter, 2005). Az érés szabályozása kettős folyamat. Szabályozza egyrészt a természet (ökológiai adottságok, talajféleségek, földrajzi kitettség és fekvés, meteorológiai tényezők: hőmérséklet, páratartalom, csapadék, napfény), másrészt az ember, a fajta, az alany, a koronaforma, a tenyészterület, a termesztéstechnológia (pl. az agrotechnika, a növényvédelem) célszerü megválasztásával. A sikeres betakarításhoz ismerni kell az érést módosító tényezőket. A korai szüret hátránya, hogy a gyümölcs nem fog utóérni, a kis méret, a nem jó íz (illat, aroma), a tárolás alatt nagymértékü a ráncosodás, a vízveszteség, a héjbarnulások. A késői szüret hátránya a nagyobb veszteség, a gyors utóérés, a rövidebb tárolhatóság, a több héjbarnulás, a nagyobb mértékü hullás, rossz szállíthatóság, hajlam a romlásra. Ha késik a szüret, a gyümölcs már a fán az öregedés folyamatába kerül. Ennek föbb jelei: puhulás, kásásság, zamatvesztés, héj- és húsbarnulás, ráncosodás, töppedés, légzésváltozás, szöveti szétesések, s végül a teljes pusztulás, amelyet mikroorganizmusok is okozhatnak. Fontos tudnunk, hogy a leszedett gyümölcs a környezetével csak a héjon keresztül végbemenő 
gázcsere által van kapcsolatban. Ezért az öregedési folyamatok csökkenthetőek a megfelelő tárolási technológiával (Soltész, 2005).

A gyümölcsök minőségének romlása abiotikus és biotikus stressz következménye. (4. ábra). A szüretelt gyümölcs a tárolás alatt is légzést folytat a rendelkezésre álló tápanyagokból (cukrok, szerves savak) és ennek eredményeként szén-dioxid keletkezik, illetve etilént állít elő, mely hatására folytatódik az érési folyamat. A betakarítás utáni műveletek - mosás, hámozás - a héjréteg sérüléseihez vezetnek, melynek következtében a vakoulákba zárt enzimek kijutnak a citoplazmába, melyek felgyorsítják a folyamatokat. További feldolgozó folyamatok, mint a vágás, szeletelés megnövelik a szövet vízaktivitását $\left(\mathrm{a}_{\mathrm{w}}\right)$ és fajlagos felületét és a gyümölcs cukortartalma táptalajt adhat a különféle mikrobáknak. A szüretelt gyümölcs a légzés következtében vizet veszít, sérülékenyebbé válik és a fizikai sérülések helyén megnő a mikrobás szennyezettség veszélye (Huy, 2006).

\begin{tabular}{|l|l|l|l|}
\hline \multicolumn{2}{|c|}{ Abiotikus tényezők } & \multicolumn{2}{c|}{ Biotikus tényezők } \\
\hline Belső sérülések & Külső sérülések & $\begin{array}{l}\text { Rovarok által okozott } \\
\text { sérülések }\end{array}$ & $\begin{array}{l}\text { Mikrobák által okozott } \\
\text { sérülések }\end{array}$ \\
\hline -pH & $\begin{array}{l}\text { Időjárás által okozott } \\
\text { sérülések (jégverés) } \\
\text { Szüretelés során szerzett } \\
\text { sérülés } \\
\text { Feldolgaktivitás }\end{array}$ & $\begin{array}{l}\text {-Különböző } \\
\text { elváltozások a } \\
\text { gyümölcs felületén }\end{array}$ & $\begin{array}{l}\text {-Különböző mikrobák } \\
\text { elszaporodása }\end{array}$ \\
-Etilén szerzett & sérülés & $\begin{array}{l}\text {-Különbözö } \\
\text { elváltozások a } \\
\text { gyümölcs belsejében }\end{array}$ & $\begin{array}{l}\text {-Lebontó enzimek } \\
\text { termelödése }\end{array}$ \\
\hline
\end{tabular}
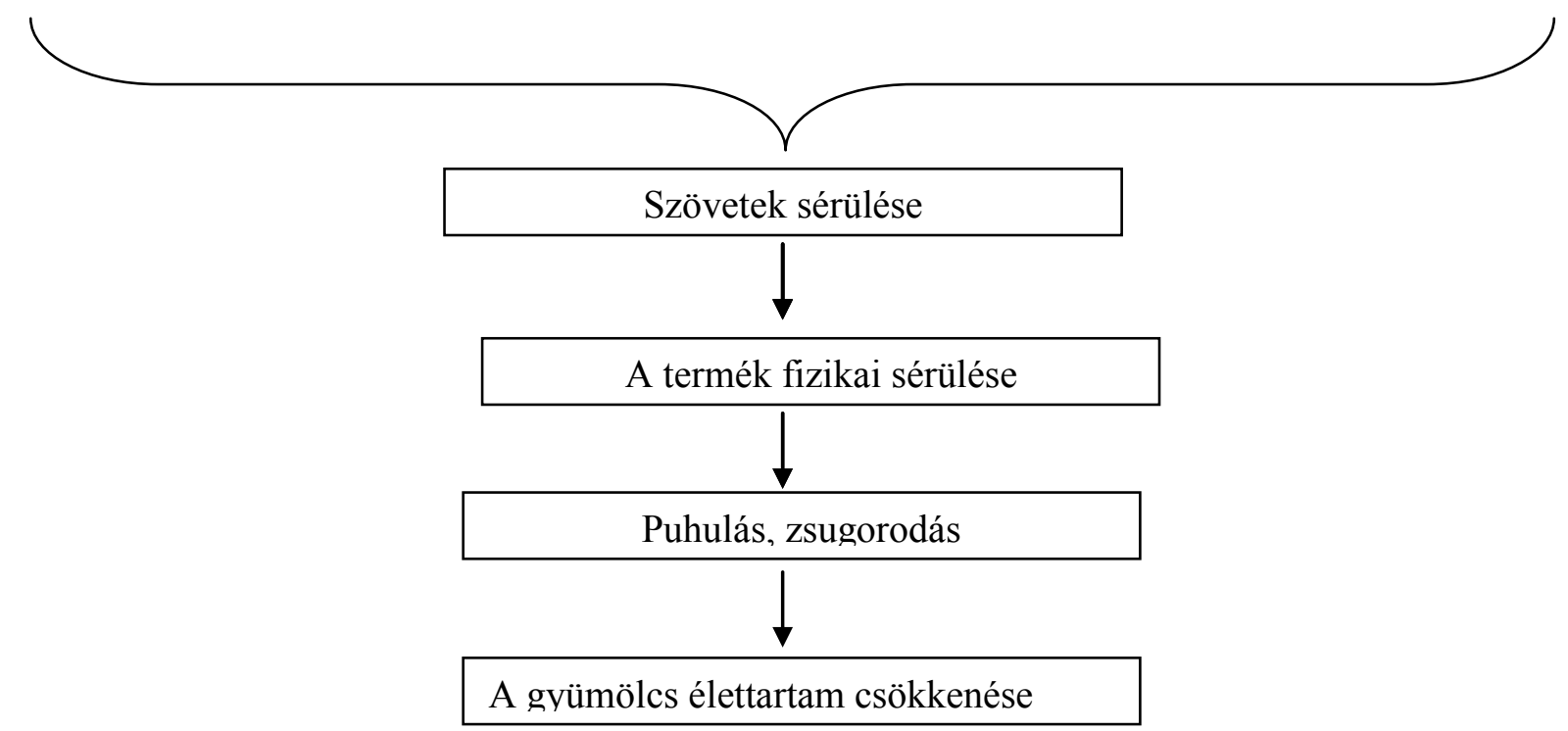

4. ábra: Gyümölcsromláshoz vezető abiotikus és biotikus tényezők Huy (2006) nyomán. 


\section{Célkitüzés}

Munkám során a hároméves (2008-2010) „Bio/organikus és integrált gyümölcstermesztést megalapozó biológiai alapok fejlesztése és technológiák kidolgozása" címü Jedlik Ányos pályázat keretében dolgoztam, a vizsgálatsorozatba bevont gyümölcsök átfogó vizsgálatán. Elsősorban áru- és beltartalmi értékek vizsgálata volt a célom, illetve a kétféle termesztési mód összehasonlítása élelmiszer-biztonsági szempontból. A magyarországi gyümölcstermesztési gyakorlatban legelterjedtebb négy gyümölcsfaj, az alma, a körte, a meggy és a cseresznye, átfogó vizsgálatáról számolok be a dolgozatban.

Gyümölcsök (különböző alma termésű és csonthéjas fajok) áruértékét befolyásoló fizikai jellemzőinek meghatározása és összehasonlító matematikai elemzése. A termesztési mód (integrált és ökológiai) hatásának vizsgálata meggy és alma esetében.

* A fent említett gyümölcsök felhasználási értékét befolyásoló beltartalmi értékek vizsgálata és nyomon követése az egyes évjáratokban.

- A gyümölcsök felületi mikrobás szennyezettségének vizsgálata a fajta, a termőhely, a termesztési mód és az évjárat függvényében az alma és a meggy esetében.

* Az egészségvédelmet biztosító biológiailag aktív anyagok, a polifenolok mennyiségének alakulása, az antioxidáns kapacitás vizsgálata és nyomon követése az egyes évjáratokban a meggy és cseresznye esetében, illetve a projekt ideje alatt évenkénti összehasonlítása az ökológiai és integrált termesztésből származó meggy mintákban. A meggy esetében az északkelet-magyarországi tájszelekció során kiválasztott fajtákban a tárolás hatásának vizsgálata a polifenol-tartalom változására.

Az antocianin tartalom mérése a meggy és cseresznye esetében. Az antocianin profil összehasonlítása a meggyben és cseresznyében. 


\section{Anyagok és módszerek}

\subsection{Vizsgálati anyagok}

\subsubsection{Gyümölcsfajták és termesztési helyeik}

\subsubsection{Meggy}

Összesen 15 fajta meggyfajtát vizsgáltam, ebből a ''Kántorjánosi 3',' 'Érdi bötermö', 'Debreceni bötermő' és 'Újfehértói fürtös' fajtákból történt párhuzamosan az integrált termesztésủ mellett az ökológiai termesztésből kapott mintáknak a vizsgálata mind a három évjáratban. Az integrált termesztésű mintákat az Újfehértói Gyümölcstermesztési Kutató és Szaktanácsadó Nonprofit Közhasznú Kht. bocsátotta rendelkezésünkre, melyek nagy része tájszelekcióval kiválasztott fajta (M4 melléklet). Az ökológiai termesztésű gyümölcsök a Nyíregyháza melletti Kabalás községből egy magán biofarmról érkeztek (M4. melléklet).

A pályázat ideje alatt a meggyből (Prunus cerasus) mindig elég nagy és reprezentatív mintát kaptunk (2. táblázat). Ezért számos fajtát sikerült szinte majdnem minden évjáratból és termesztési módból megvizsgálni. Ökológiai termesztésre legalkalmasabbak azok a meggyfajták, amelyek valamely fontos betegséggel, illetve kártevővel szemben rezisztensek, illetve toleránsak.

A meggy ökológiai termesztése akkor fog fellendülni, ha termesztésbe kerülnek azok a betegségeknek ellenálló fajták, amelyek kiküszöbölik a 'Csengődi' meggyfajta termesztésbeni hiányosságait (nem egyöntetü érés, a gyümölcs nehéz leválása, nehezen nevelhető koronaszerkezet). A meggyre, mint biotermékre piaci igény van Európában, de a jelenlegi fajtákat megvédeni a moníliától szinte reménytelen (Nyéki, 2008).

A fenti fajtákat Nyéki és munkatársai (2008) vizsgálták fagytürés szempontjából virágzáskor. Ez alapján 2 csoportot tudtak elkülöníteni. Fagytűrő fajta volt a 'Pándy 279', 'Újfehértói fürtös', 'Kántorjánosi 3', 'Oblacsinszka', 'Éva (T)' klón, 'Petri' és a, 'Debreceni bötermö'. Fagyérzékenyfajta az 'Érdi bőtermö' és 'Csengődi'. 
2. táblázat: A dolgozatban szereplő meggy fajták jellemzői (Soltész (2005) és Faluba és munkatársai (1982) nyomán)

\begin{tabular}{|l|l|l|}
\hline \multicolumn{2}{|l|}{ Cigánymeggyek (Convarietas acida) } \\
\hline Fajta & Eredete & Jellemzöi \\
\hline $\begin{array}{l}\text { Cigány - } \\
\text { A Debreceni Városi Kertészet gyümölcsöséböl } \\
\text { Brózik Sándor szelektálta 1952-ben. }\end{array}$ & $\begin{array}{l}\text { Június végén érik. Gyümölcse gömbölyded, átlagtömege 3,1g. Héja sötétpiros. Sötétpiros húsa lédús, } \\
\text { festólevü. Íze igen savas. Gépi rázással is szüretelhetö. Gyümölcse fóként feldolgozásra alkalmas (dzsem, íz, } \\
\text { lé). }\end{array}$ \\
\hline $\begin{array}{l}\text { Cigány- } \\
59\end{array}$ & Tájfajta kutatás során Brózik S. szelektálta. & $\begin{array}{l}\text { Június végén érik. Gyümölcse 3,3g átlagtömegü. Héja sötétpiros. Sötétpiros húsa lédús, festölevü. Íze igen } \\
\text { savas. Gyümölcse fóként feldolgozásra alkalmas (dzsem, íz, lé). }\end{array}$ \\
\hline
\end{tabular}

\begin{tabular}{|c|c|c|}
\hline \multicolumn{3}{|c|}{ Maraszkameggyek (Convarietas vulgaris - provarietas maraska) } \\
\hline Fajta & Eredete & Jellemzöi \\
\hline Csengödi & $\begin{array}{l}\text { Bosnyák meggy populációból kiemelt fajta. A } \\
\text { Csengőd-Akasztó vidékén található un. Bosnyák } \\
\text { meggyek közül szelektálta Apostol János }\end{array}$ & $\begin{array}{l}\text { Június elején érik. Gyümölcsének átlagtömege } 4 \mathrm{~g} \text {. Alakja kissé megnyúlt gömb. Húsa középkemény, rostos, } \\
\text { bőlevü. Nagyfokú toleranciával rendelkezik a moníliás virág-és hajtáselhalással, illetve a blumeriellás } \\
\text { levélfoltosodással szemben. A fajta hibája, hogy gyümölcse nem egyöntetủen érik és a kocsánytól nem válik } \\
\text { el szárazon. Mind friss fogyasztásra, mind ipari célra alkalmas. }\end{array}$ \\
\hline $\begin{array}{l}V N-1 \\
V N-4 \\
V N-7\end{array}$ & $\begin{array}{l}\text { A Bosnyák meggy fajtakörből szelektált } \\
\text { változat. }\end{array}$ & $\begin{array}{l}\text { Gyümölcsei egyszerre érnek a fán, teljes érésben kocsányuk szárazon válik. Érési ideje június harmadik fele. } \\
\text { Gyümölcs kicsi vagy közerpes }(3,5-5,0 \mathrm{~g}) \text {. Alakja kissé megnyúlt gömb, héja középvastag, sötét kárminpiros } \\
\text { színü. } \\
\text { Fő értékét a betegségekkel (blumeriella, monília) szembeni nagyfokú ellenállósága adja, így a környezetbarát } \\
\text { technológia alkalmazására kiválóan megfelel. Gyümölcse frissen fogyasztható, befótt készítésére és } \\
\text { fagyasztásra közepesen, ivólé készítésére kiválóan alkalmas. Antioxidáns tartalma nagy, természetes } \\
\text { élelmiszer-színezékként is használható. }\end{array}$ \\
\hline $\begin{array}{l}\text { Oblacsin } \\
\text { szka }\end{array}$ & $\begin{array}{l}\text { A Bosnyák meggy fajtakörből szelektált } \\
\text { változat. }\end{array}$ & $\begin{array}{l}\text { Az édesipar számára fontos fajta, mely kisméretü gyümölcsével a bon-bon meggy édesipari termék kiváló } \\
\text { alapanyaga. A fajta Magyarországra gyökérsarjak formájában került be. }\end{array}$ \\
\hline
\end{tabular}




\begin{tabular}{|c|c|c|}
\hline \multicolumn{3}{|c|}{ Üvegmeggyek (Convarietas vulgaris - provarietas vulgaris) } \\
\hline Fajta & Eredete & Jellemzöi \\
\hline Pipacs & $\begin{array}{l}\text { A Pándy } 279 \text { és a Császármeggy keresztezésével } \\
\text { állította elő 1954-ben Maliga Péter. }\end{array}$ & $\begin{array}{l}\text { Június közepén érik. Gyümölcse felülről nyomott, gömbölyded, 5,0 g átlagtömegủ. Héja világos, élénk, kárminpiros. } \\
\text { Húsa középkemény, lédús, savanykás. Főként exportra termesztik }\end{array}$ \\
\hline $\begin{array}{l}\text { Érdi } \\
\text { bötermö }\end{array}$ & $\begin{array}{l}\text { A Pándy } 38 \text { és a Nagy angol fajták keresztezésével } \\
\text { állította elő Maliga Péter 1953-ban. }\end{array}$ & $\begin{array}{l}\text { Június közepén érik. Felülröl kissé nyomott gyümölcse gömbölyded, 5,6g átlagtömegü. Héja sötétpiros. Húsa finoman } \\
\text { rostos, festö levü, kellemesen savas-édes. Kiváló áruértékü, nagy gyümölcsű fajta, de fája törékeny, virágzása korábbi } \\
\text { (virágai könnyebben elfagynak), virágai érzékenyek a moníliára. Friss fogyasztásra, ipari célra alkalmas. }\end{array}$ \\
\hline $\begin{array}{l}\text { Debreceni } \\
\text { bötermö }\end{array}$ & kelet-magyarországi tájszelekció & $\begin{array}{l}\text { Június végén érik. Húsa középkemény, finoman rostos. Íze kellemesen harmonikus meggyíz, édesebb, mint az Újfehértói } \\
\text { fürtös. Biztonságosan termő fajta. Moníliára és a blumeriellás levélfoltosságra közepesen érzékeny. Június végén } \\
\text { szüretelhető gyümölcse világosabb, festőlevủ. Gépi betakarításra alkalmas. Minden célra kíválló. }\end{array}$ \\
\hline $\begin{array}{l}\text { Kántorján } \\
\text { osi } 3\end{array}$ & Közel áll az Újfehértói fürtöshöz & $\begin{array}{l}\text { Július elején érik. Gyümölcsének átlagtömege } 6 \mathrm{~g} \text {. Húsa kemény, finoman rostos, bölevü. Kemény konzisztenciája és } \\
\text { magas szárazanyag tartalma miatt a legjobb konzerv- és nyersexport fajta. A blumeriellás levélfoltossággal szemben alig } \\
\text { fogékony, moniliára közepesen érzékeny. PNRSV vírussal szemben toleráns, így fájának életkora hosszabb. Gépi } \\
\text { betakarításra alkalmas. }\end{array}$ \\
\hline $\begin{array}{l}\text { Újfehértói } \\
\text { fürtös }\end{array}$ & $\begin{array}{l}\text { Anyafáját Istenes D. újfehértói kertjében szelektálták } \\
\text { 1961-ben. }\end{array}$ & $\begin{array}{l}\text { Június végén -július elején érik. Felülröl kissé lapított, gömb alakú gyümölcse } 5,1 \mathrm{~g} \text { átlagtömegü. Héja éretten bordópiros. } \\
\text { Húsa bőlevü, erösen savas-édes, harmónikus ízü. Géppel szüretelhető. Friss fogyasztásra és exportra alkalmas. Moníliára } \\
\text { mérsékelten fogékony, a blumeriellára közepesen érzékeny. A lombosfa-fehérmollyal szemben viszont az ez a fajta a } \\
\text { legellenállóbb. }\end{array}$ \\
\hline Pándy 279 & $\begin{array}{l}\text { A Kertészeti Egyetem kamaraerdei } \\
\text { törzsgyüjteményéből Brózik Sándor szelektálta. }\end{array}$ & $\begin{array}{l}\text { Érési ideje: június vége-július eleje. Gyümölcsének átlagtömege 6,3g. Gyümölcse felülröl nyomott gömbölyded. Erős } \\
\text { héja sötétbordó. Szívós húsa piros, lédús, erősen savas, jellegzetes zamatú. Virágrügyei és virágai fagytürők. Géppel } \\
\text { szüretelhető. }\end{array}$ \\
\hline Petri & $\begin{array}{l}\text { kelet-magyarországi tájszelekció: Lövőpetri } \\
\text { környékén szelektálta Szőke Ferenc }\end{array}$ & $\begin{array}{l}\text { Gyümölcse középnagy ( } 5-5,5 \mathrm{~g}) \text {, kissé lapított gömb alakú. Héjának színe fénylő bordópiros. Húsa kemény, mérsékelten } \\
\text { festőlevü. Íze harmonikusan savas-édes, a friss fogyasztás során nem fanyar. Hullásra nem hajlamos. Friss fogyasztásra } \\
\text { és ipari feldolgozásra egyaránt alkalmas. }\end{array}$ \\
\hline Éva & $\begin{array}{l}\text { kelet-magyarországi tájszelekció } \\
\text { Fényeslitke környékén házikertekben szelektálta } \\
\text { Szöke Ferenc magánnemesítő. }\end{array}$ & $\begin{array}{l}\text { Július elején érik. Gyümölcsméretét, tetszetősségét és ízletességét tekintve az 'Újfehértó fürtös'-höz hasonló fajtajelölt. } \\
\text { Gyümölcse középnagy, vagy nagy }(5,4 \mathrm{~g}) \text {. Alakja gömbölyded, felülröl kissé nyomott. Friss fogyasztásra és ipari } \\
\text { feldolgozásra egyaránt alkalmas. }\end{array}$ \\
\hline
\end{tabular}




\subsubsection{Cseresznye}

A 3 éves munka során a 2003-ban létrehozott nagykutasi ültetvényről származó 19 cseresznye (Prunus avium) fajtából 3 fajtát vizsgáltam a projekt keretében. Nagykutason (M4. melléklet) a kísérletbe állított cseresznyefajták többsége a magyarországi termesztés számára perspektivikus új fajta. Az eddigi, elsősorban külföldi tapasztalatok alapján termőképességüket és gyümölcsminőségüket tekintve is értékesek, beilleszthetőek a jelenlegi fajtasorba, gyümölcsük a hazai friss piac számára és export célokra is megfelelő. A 19 fajta közül a 'Firm Red', 'Katalin' és 'Regina' fajtákból kaptunk mind a 3 évben.

A kapott három cseresznyefajta mind integrált termesztésü, ezért ebben az esetben nem volt lehetőség az ökológiai és integrált termesztési mód összehasonlítására.

Az egyes fajták rövid jellemzése: 'Katalin' (Prunus avium cv. Katalin): a 'Germersdorfi Óriás ' és a 'Podjebrád' hibridje, érési ideje július eleje. Gyümölcse sötétbordó, nagy, nyújtott gömb, kemény húsú, ropogós, édes-savas, harmonikus ízü, a 'Hedelfingenihez' és a 'Germersdorfi Óriásé 'hoz hasonló, de gyümölcsminősége lényegesen jobb, elsősorban friss fogyasztásra, de fagyasztásra és konzervipari felhasználásra is alkalmas. Géppel is betakarítható. Porzói: 'Van', 'Linda', 'Germersdorfi' klónok. 'Regina'(Prunus avium cv. Regina): Nagyon kései érésü és igen nagyméretü cseresznye, amely még a tárolást is kiválóan türi. A külföld egyik legnépszerübb fajtája, mely Magyarországon is helyet követel magának. Porzása nem egyszerü, több, vele azonos időben virágzó fajtával kell társítani. 'Firm Red' (Prunus avium cv. Firm Red): Középkorai érésű, piros alapszínü, cinóbervörös fedőszín borítja. Húsa kemény, roppanós. Magas cukortartalom jellemzi, kedvező sav/cukor aránya.

\subsubsection{Alma}

Kutatómunkánk során a vizsgálati anyag legnagyobb részét, a legnagyobb mintaszámmal az alma (Malus domestica) tette ki. Mindhárom (2008-2009-2010) évjáratból összesen 33 fajtát és jelentős számú mintát vizsgáltam (3-8. táblázat) (M3 melléklet 1-5.kép). A három évjáratban az ökológiai és integrált termesztési mód keretében termesztett almák közüll a 'Remo', 'Prima', Gala', 'Topáz', 'Idared' és, 'Rajka' fajtákat vizsgáltam és hasonlítottam össze. Az alma minták termesztési helye az Újfehértói Gyümölcstermesztési Kutató és Szaktanácsadó Kht., valamint a Debreceni Egyetem Agrár-és Gazdálkodástudományi Centrumának Debreceni Tangazdaság és Tájkutató Intézet Pallagi Kertészeti Kísérleti Telep és Tanüzeme. Az utóbbi 90 hektáros kísérleti telep, melynek ökológiai viszonyai és talajtípusa jól reprezentálják a Dél-Nyírségre 
jellemző sajátosságokat. Termőhelyi adottságai sokféle gyümölcs termesztését teszik lehetővé, többek között a Magyarországon őshonos almáét is (M4. melléklet).

A vizsgált fajtákat alakkör szerint csoportosítottam a jobb áttekinthetőség érdekében táblázatos elrendezésben, amelyben az egyes fajták főbb tulajdonságait szemléltetem (3-8. táblázat és M3 melléklet). A táblázatban nem szerepel a négy újonnan nemesített fajta (A11/28 - 'Davidino', M 10/97, AS 10/31 és AS 8/31 - 'Soltadino').

Továbbá nem szerepel a táblázatban a Pink Lady®, mely a déli féltekén, Ausztráliában ujjonan nemesített fajta a Lady Williams és a Golden Delicious keresztezéséből, márkavédett fajta lett. Ez a faj közepes méretű és hosszúkás formájú. Ami egyedülállóvá teszi, az a félreismerhetetlen rózsaszín (pink) színezete. A Pink Lady® egy lédús és ropogós almafaj, szaftos, enyhén savanykás aromával, és magas cukortartalommal. 
3. táblázat: Gala alakkör (Tóth, 2009 nyomán)

\begin{tabular}{|c|c|c|c|c|c|}
\hline Fajta & Közvetlen szülöfajták & Érési idö & $\begin{array}{l}\text { Fogyaszztási érettség és } \\
\text { tárolhatóság }\end{array}$ & Gyümölcsjellemzők & Betegségellenállóság \\
\hline $\begin{array}{l}\text { Gala } \\
\text { változatai: } \\
\text { GalaMust } \\
\text { és a } \\
\text { Galaxy }\end{array}$ & $\begin{array}{l}\text { Kidd's Orange Red } \times \\
\text { Golden Delicious (Új- } \\
\text { Zéland) }\end{array}$ & VIII. vége & $\begin{array}{l}\text { Szüret után rövidesen } \\
\text { fogyasztható, hütőtárolóban } \\
\text { 3-4 hónapig eltartható }\end{array}$ & $\begin{array}{l}\text { Kicsi vagy közepes, sárgáspirosan } \\
\text { csíkozott, fedőszíne világospiros, húsa } \\
\text { kemény, ropogós, lédús, édeskés, } \\
\text { savtartalma kevés. }\end{array}$ & \\
\hline
\end{tabular}

4. táblázat: egyéb fajták (Tóth, 2009 nyomán)

\begin{tabular}{|c|c|c|c|c|c|}
\hline Fajta & Közvetlen szülöfajták & Érési idö & $\begin{array}{l}\text { Fogyasztási érettség és } \\
\text { tárolhatóság }\end{array}$ & Gyümölcsjellemzök & Betegségellenállóság \\
\hline $\begin{array}{l}\text { Granny } \\
\text { Smith }\end{array}$ & $\begin{array}{l}\text { Alapfajta, a French } \\
\text { Crab magonca } \\
\text { (Ausztrália) }\end{array}$ & $\begin{array}{l}\text { X. vége - XI. első } \\
\text { hete (bőtermö, } \\
\text { alternanciára } \\
\text { hajlamos) }\end{array}$ & $\begin{array}{l}\text { Hagyományos hütóházakban } \\
\text { márciusig tárolható. }\end{array}$ & $\begin{array}{l}\text { Középnagy vagy nagy (160-180g), kerek } \\
\text { vagy csonkakúp alakú, zöld színü, héja } \\
\text { viaszos. Húsa kemény, íze enyhén } \\
\text { savanykás, zamata alig érezhető. }\end{array}$ & \\
\hline Braeburn & $\begin{array}{l}\text { Lady Hamilton } \times \text { Cox } \\
\text { Orange (Új-Zéland) }\end{array}$ & $\begin{array}{l}\text { X. második } \\
\text { felében, több } \\
\text { menetben } \\
\text { szüretelhető }\end{array}$ & Késő tavaszig tárolható. & $\begin{array}{l}\text { Középnagy, alakja vagy megnyúlt, vagy } \\
\text { lapítottabb.Felülete barnáspiros fedőszínnel } \\
\text { borított. Húsa kemény, íze kellemes. }\end{array}$ & $\begin{array}{l}\text { Gyümölcsfoltosodásra } \\
\text { hajlamos }\end{array}$ \\
\hline Fuji & $\begin{array}{l}\text { Red Delicious } \times \text { Ralls } \\
\text { Janet (Japánban } \\
\text { nemesített fajta) } \\
\text { (Ralls Janet a Cox } \\
\text { Orange egyik } \\
\text { változata) }\end{array}$ & $\begin{array}{l}\text { XI. decembertől } \\
\text { fogyasztható }\end{array}$ & $\begin{array}{l}\text { Májusig minőségvesztés } \\
\text { nélkül tárolható. }\end{array}$ & $\begin{array}{l}\text { Gyümölcse külföldi leírások szerint nagy } \\
\text { vagy igen nagy (Japánban } 300 \text { g fölötti is } \\
\text { lehet), hazánkban inkább középnagy. } \\
\text { Alakja megnyúlt, csaknem hengeres. A } \\
\text { gyümölcs felületének legfeljebb a felét } \\
\text { borítja mosott narancs- és barnáspiros } \\
\text { fedöszín. Húsa kemény, bölevü, kítünő } \\
\text { mézédes ízét enyhe sav teszi harmonikussá. }\end{array}$ & \\
\hline $\begin{array}{l}\text { Sonya } \\
\text { (Nevson) }\end{array}$ & Gala $\times$ Red Delicious & X. eleje & Áprilisig eltartható & $\begin{array}{l}\text { A sárga alapszínt piros fedőszín borítja, } \\
\text { nagyméretǘ és hosszúkás különleges } \\
\text { formájú. A magas cukortartalom és } \\
\text { megfelelö arányú savtartalom kiváló ízt } \\
\text { biztosít. }\end{array}$ & \\
\hline
\end{tabular}


5. táblázat: Jonathan alakkör és Jonathan hibridek (Tóth, 2009 nyomán)

\begin{tabular}{|c|c|c|c|c|c|}
\hline Fajta & Közvetlen szülöfajták & Érési idö & $\begin{array}{l}\text { Fogyasztási érettség és } \\
\text { tárolhatóság }\end{array}$ & Gyümölcsjellemzök & Betegségellenállóság \\
\hline Jonathan & $\begin{array}{l}\text { Esopus Spitzenberg } \\
\text { magonca (USA) }\end{array}$ & IX. közepe & $\begin{array}{l}\text { A gyümölcsök tárolhatósága } \\
\text { behatárolt, és sok } \\
\text { problémával jár. A } \\
\text { gyümölcsök tárolhatósága } \\
\text { kalciumos permetezéssel } \\
\text { javítható. }\end{array}$ & $\begin{array}{l}\text { Gyümölcse kicsi tetszetős színű és alakú, } \\
\text { nyomódásra nem nagyon érzékeny. }\end{array}$ & $\begin{array}{l}\text { A betegségekkel } \\
\text { szembeni } \\
\text { fogékonyságából adódó } \\
\text { problémákat intenzív } \\
\text { növényvédelemmel és } \\
\text { jó kondícióban tartott } \\
\text { fákkal kell megelőzni. }\end{array}$ \\
\hline Jonagold & $\begin{array}{l}\text { Golden Delicious } \times \\
\text { Jonathan (USA) }\end{array}$ & $\begin{array}{l}\text { IX. vége }-X . \\
\text { eleje, több } \\
\text { menetben }\end{array}$ & $\begin{array}{l}\text { Áprilisig eltartható, de } \\
\text { élvezeti értéke decembertől } \\
\text { kezdve csökken, hosszabb } \\
\text { ideig eredményesen } \\
\text { szabályozott légtérben } \\
\text { tárolható }\end{array}$ & $\begin{array}{l}\text { Nagy vagy nagyon nagy (230-250g), héja } \\
\text { viaszos. Alapszíne világossárga mosott, } \\
\text { fedőszíne élénkpiros.Ize savanykás-édes, } \\
\text { füszeres. Napégésre hajlamos }\end{array}$ & $\begin{array}{l}\text { Fogékonysága a } \\
\text { venturális varasodással } \\
\text { szemben közepes, a } \\
\text { lisztharmattal szemben } \\
\text { a 'Golden'-nél } \\
\text { valamivel nagyobb. } \\
\end{array}$ \\
\hline $\begin{array}{l}\text { Idared / } \\
\text { Red } \\
\text { Idared }\end{array}$ & $\begin{array}{l}\text { Jonathan } \times \text { Wagener } \\
\text { (USA) }\end{array}$ & X. elején & $\begin{array}{l}\text { Savai lassan bomlanak, ezért } \\
\text { a fogyasztásra } \\
\text { legalkalmasabb érettségi } \\
\text { állapotot tavasszal éri el. }\end{array}$ & $\begin{array}{l}\text { Középnagy vagy nagy (180-200g), héja } \\
\text { sima, enyhén viaszos. Alapszíne } \\
\text { világossárga, napos oldalán egybefüggően } \\
\text { élénkpiros lesz. Enyhén savanykás, lédús. }\end{array}$ & Lisztharmatra fogékony \\
\hline
\end{tabular}

6. táblázat: Red Delicious alakkör (Tóth, 2009 nyomán)

\begin{tabular}{|l|l|l|l|l|l|}
\hline Fajta & Közvetlen szülöfajták & Érési idö & $\begin{array}{l}\text { Fogyasztási érettség és } \\
\text { tárolhatóság }\end{array}$ & Gyümölcsjellemzök \\
\hline $\begin{array}{l}\text { Campbell } \\
\text { (Redchief } \\
\text { Delicious) }\end{array}$ & $\begin{array}{l}\text { A Starkrimson } \\
\text { Delicious } \\
\text { rügymutációja }\end{array}$ & $\begin{array}{l}\text { IX. vége }- \text { X. } \\
\text { eleje }\end{array}$ & Koratavaszig tárolható & $\begin{array}{l}\text { Gyümölcse nagy }((170-190 \mathrm{~g}), \text { alakja } \\
\text { megnyúltabb. Teljes felülete csíkozott, } \\
\text { mélypiros fedöszín borítja. }\end{array}$ \\
\hline
\end{tabular}


7. táblázat: Golden Delicious alakkör és Golden jellegü hibridek (Tóth, 2009 nyomán)

\begin{tabular}{|c|c|c|c|c|c|}
\hline Fajta & Közvetlen szülöfajták & Érési idö & $\begin{array}{l}\text { Fogyasztási érettség és } \\
\text { tárolhatóság }\end{array}$ & Gyümölcsjellemzök & Betegségellenállóság \\
\hline $\begin{array}{l}\text { Golden } \\
\text { Delicious, } \\
\text { rügynutációja } \\
\text { a Golden } \\
\text { Reinders }\end{array}$ & $\begin{array}{l}\text { Alapfajta, de } \\
\text { valószínüsítik, hogy a } \\
\text { Grimes Golden } \\
\text { véletlen magonca } \\
\text { (1830, USA) }\end{array}$ & $\begin{array}{l}\text { IX. vége }-X . \\
\text { eleje }\end{array}$ & $\begin{array}{l}\text { Szüret után azonnal } \\
\text { fogyasztható, minőségét } \\
\text { megfelelö tárolással hat } \\
\text { hónapig megőrzi. Tárolás } \\
\text { utáni állékonysága jó, de az } \\
\text { erős fonnyadás miatt } \\
\text { gyorsan romlik a külleme. }\end{array}$ & $\begin{array}{l}\text { Középnagy vagy nagy, gömbölyded } \\
\text { vagy enyhén megnyúlt csonka kúp } \\
\text { alakú. Héja vékony, könnyen sérül, } \\
\text { az érés kezdetén zöldessárga, később } \\
\text { sárga. Gyümölcs napégésre } \\
\text { hajlamos. Húsa sárgás, édeskés } \\
\text { kellemes ízü, enyhén savas, } \\
\text { harmonikus. }\end{array}$ & $\begin{array}{l}\text { Lisztharmatra alig fogékony, } \\
\text { viszont varrasodásra } \\
\text { fokozottan hajlamos. }\end{array}$ \\
\hline Elstar & $\begin{array}{l}\text { Ingrid Marie* } \times \\
\text { Golden Delicious } \\
\text { (Hollandia) }\end{array}$ & $\begin{array}{l}\text { VIII. vége - IX. } \\
\text { eleje } \\
\text { (alternanciára } \\
\text { hajlamos) }\end{array}$ & $\begin{array}{l}\text { Normál tárolóban januárig } \\
\text { eltartható. Érzékeny a magas } \\
\mathrm{CO}_{2} \text { tartalomra, ez esetben } \\
\text { húsbarnulás léphet fel. }\end{array}$ & $\begin{array}{l}\text { Középnagy, fényes sárga alapon } \\
\text { narancsvörös fedöszínnel. Ízletes, } \\
\text { lédús, magas sav-és } \\
\text { cukortartalommal }\end{array}$ & \\
\hline Sampion & $\begin{array}{l}\text { Golden Delicious } \times \\
\text { Cox Orange } \\
(\text { Csehországban } \\
\text { nemesített fajta) }\end{array}$ & $\begin{array}{l}\text { Két menetben: } \\
\text { IX. közepe és } \\
\text { vége }\end{array}$ & 4-5 hónapig tárolható & $\begin{array}{l}\text { Középnagy vagy nagy, gömbölyded } \\
\text { alakú. Héja sima, nem viaszos. } \\
\text { Piros fedőszíne a gyümölcs } \\
\text { felületének } 60-70 \% \text {-át beborítja } \\
\text { csíkozottan. }\end{array}$ & $\begin{array}{l}\text { Varrasodásra és lisztharmatra } \\
\text { alig fogékony }\end{array}$ \\
\hline Pinova & $\begin{array}{l}\text { Golden Delicious } \times \\
\text { (Cox Orange } \times \\
\text { Duchess of } \\
\text { Oldenburg**) } \\
\text { (Németország) }\end{array}$ & $\begin{array}{l}\text { IX. vége }-X \text {. } \\
\text { eleje }\end{array}$ & Késő tavaszig tárolható & $\begin{array}{l}\text { Középnagy }(150-170 \mathrm{~g}) \text {, enyhén } \\
\text { kúpos. Alapszíne éretten sárga több } \\
\text { mint } 50 \% \text { mosott piros fedöszínnel } \\
\text { borított. Savanykás }\end{array}$ & Alig érzékeny \\
\hline Mutsu & $\begin{array}{l}\text { Golden Delicious } \times \\
\text { Indo*** fajták } \\
\text { keresztezése }\end{array}$ & $\begin{array}{l}\text { X. elején (8-10 } \\
\text { nappal a Golden } \\
\text { D. után) }\end{array}$ & Áprilisig eltartható & $\begin{array}{l}\text { Nagy }(230-300 \mathrm{~g}) \text {, héja fényes, kissé } \\
\text { viaszos, nem perzselődik. Napégésre } \\
\text { hajlamos. Füszeres íze tárolás alatt } \\
\text { alakul ki. }\end{array}$ & \\
\hline Rubinette & $\begin{array}{l}\text { Golden Delicious } \times \\
\text { Cox Orange (Svájcban } \\
\text { nemesített fajta) }\end{array}$ & IX. vége & November végéig eltartható & $\begin{array}{l}\text { Kicsi vagy közepesen nagy méretü, } \\
\text { zöldessárga színü.Gyümölcshúsa } \\
\text { kemény, és finom szövetü. Nagyon } \\
\text { lédús, magas cukor-, és magas } \\
\text { savtartalommal. }\end{array}$ & \\
\hline
\end{tabular}




\begin{tabular}{|c|c|c|c|c|c|}
\hline Fajta & Közvetlen szülöfajták & Érési idö & $\begin{array}{l}\text { Fogyasztási érettség és } \\
\text { tárolhatóság }\end{array}$ & Gyümölcsjellemzők & Betegségellenállóság \\
\hline Prima & $\begin{array}{l}\text { PRI 14-510 × NJ } 123249 \\
\text { (USA) }\end{array}$ & VIII. vége & 3-4 hétig tárolható & $\begin{array}{l}\text { Középnagy vagy nagy gyümölcs, 50\% } \\
\text { feletti mosott piros fedőszín, íze } \\
\text { kellemes, savanykás, illatos. }\end{array}$ & $\begin{array}{l}\text { Varasodás: rezisztens } \\
\text { Lisztharmat: alig fogékony } \\
\text { Tüzelhalás: mérsékelten } \\
\text { rezisztens }\end{array}$ \\
\hline Rebella & Glden del. $\times$ Remo & IX. első fele & Decemberig tárolható & $\begin{array}{l}\text { Gyümölcse közép nagy - nagy (150- } \\
200 \text { g), megnyúlt, hengeres. Alapszíne } \\
\text { zöldessárga, fedőszíne fénylő piros, } \\
\text { enyhén csíkozott. Húsa roppanó, } \\
\text { kemény, lédús, íze édes-savas, zamatos. }\end{array}$ & $\begin{array}{l}\text { Varasodás: rezisztens } \\
\text { Lisztharmat: rezisztens } \\
\text { Tűzelhalás: ellenálló }\end{array}$ \\
\hline Remo & $\begin{array}{l}\text { James Grieve** } \times \text { Malus } \\
\text { floribunda } \mathrm{F}_{3} \text { nemzedék } \\
(\text { Németország) }\end{array}$ & IX. közepe & $\begin{array}{l}\text { Normál tárolóban januárig } \\
\text { tárolható, ipari célra alkalmas }\end{array}$ & $\begin{array}{l}\text { Kis vagy közepes méretü }(120-160 \mathrm{~g}) \text {, } \\
\text { alakja lapított gömb, felülete } 2 / 3 \\
\text { részben vörös mosott fedőszínnel } \\
\text { borított. Íze savas, étkezésre kevésbé } \\
\text { alkalmas }\end{array}$ & $\begin{array}{l}\text { Varasodás: rezisztens } \\
\text { Lisztharmat: rezisztens } \\
\text { Tủzelhalás: mérsékelten } \\
\text { fogékony }\end{array}$ \\
\hline Rubinola & $\begin{array}{l}\text { Prima } \times \text { Rubin } \\
(\text { Csehország) }\end{array}$ & IX. második fele & Tavaszig tárolható & $\begin{array}{l}\text { középnagy gyümölcs, narancssárga } \\
\text { fedőszín, harmonikus íz, édes-savas } \\
\text { karakter, kiválóaroma }\end{array}$ & $\begin{array}{l}\text { Varasodás: rezisztens } \\
\text { Lisztharmat: alig fogékony }\end{array}$ \\
\hline Rajka & $\begin{array}{l}\text { Sampion }(\text { Golden D. } \times \\
\text { Cox Orange }) \times \text { Katka } \\
\text { (Lord Lambourne* }) \\
(\text { Csehországi nemesítés) }\end{array}$ & IX. második fele & $\begin{array}{l}\text { Februárig tárolható étkezési } \\
\text { fajta }\end{array}$ & $\begin{array}{l}\text { Középnagy }(130-150 \mathrm{~g}), 50 \% \text { feletti } \\
\text { mosott piros fedőszín, középkemény, } \\
\text { lédús hús, édeskés-savanykás füszeres } \\
\text { íz }\end{array}$ & $\begin{array}{l}\text { Varasodás: rezisztens } \\
\text { Lisztharmat: alig fogékony }\end{array}$ \\
\hline Florina & $\begin{array}{l}\text { Jonathan } \times \text { PRI 612-1 } \\
\text { (Franciaország) }\end{array}$ & $\begin{array}{l}\text { IX. vége }-X . \\
\text { eleje }\end{array}$ & Februárig tárolható & $\begin{array}{l}\text { Középnagy vagy nagy }(170-180 \mathrm{~g}) \text {, } \\
\text { alakja lapított gömb, piros mosott } \\
\text { fedőszín, erös hamvasság }\end{array}$ & $\begin{array}{l}\text { Varasodás: rezisztens } \\
\text { Lisztharmat: alig fogékony } \\
\text { Tüzelhalás: alacsony } \\
\text { fogékonyság }\end{array}$ \\
\hline Rewena & $\begin{array}{l}\text { (Cox Orange } \times \\
\text { Oldenburg) } \times \text { Malus } \\
\text { floribunda } \mathrm{F}_{3} \text { nemzedék } \\
(\text { Németország) }\end{array}$ & $\begin{array}{l}\text { IX. vége }-X . \\
\text { eleje }\end{array}$ & Februárig tárolható & $\begin{array}{l}\text { Középnagy, nagy (150-200g), } \\
\text { megnyúlt gömb alakú, felületének } \\
80 \% \text {-át mosott fedőszín borítja. Húsa } \\
\text { savanykás, lédús, aromája kellemes. }\end{array}$ & $\begin{array}{l}\text { Varasodás: rezisztens } \\
\text { Lisztharmat: rezisztens } \\
\text { Tüzelhalás: rezisztens } \\
\text { Kiemelkedő német fajta! }\end{array}$ \\
\hline Topaz & $\begin{array}{l}\text { Rubin } \times \text { Vanda } \\
(\text { Csehország) }\end{array}$ & $\begin{array}{l}\text { IX. vége }-X \text {. } \\
\text { eleje }\end{array}$ & Normál tárolóban januárig & $\begin{array}{l}\text { Középnagy, lapított-gömbölyded } \\
\text { gyümölcs, narancsvörös mosott és } \\
\text { csíkozott fedőszín, lédús, szilárd hús, } \\
\text { édes kellemes íz }\end{array}$ & $\begin{array}{l}\text { Varasodás: rezisztens } \\
\text { Lisztharmat: rezisztens } \\
\text { Tüzelhalás: rezisztens }\end{array}$ \\
\hline
\end{tabular}




\subsubsection{Körte}

A megvizsgált körtéket (Pyrus communis) két, integrált termesztést folytató termőhelyről kaptuk. Az 'Fétel apát' ('Abate fetel') fajta termőhelye Szepetnek-Bánfapuszta, mely 15 km-re fekszik Nagykanizsától (M4. melléklet). Agyagos, barna erdőtalajon elhelyezkedő 7 hektáros öntöző rendszerrel ellátott ültetvény, melyet 1997-1998-ban telepítettek oltott birs alanyon. Az átlagos terméshozam 2008-ban 12,6 kg/fa volt. A többi fajta ('Bosc kobak', 'Vilmos', 'Packham's Triumph', 'Conference') termőhelye Feketesár, szintén 15 km-re Nagykanizsától. Az ültetvény nem meszes, szárazabb, homokos talajon terül el 83 hektáron, fiatal ültetvény. Több fázisban történt a telepítés 1997-től 2003-ig. Az 1997-199-es ültetvény átlagos terméshozama 2008-ban 37-45 kg/fa volt, a 2000-2001-es ültetvényé 27-35 kg/fa, míg a 2003 as ültetvényé $5 \mathrm{~kg} / \mathrm{fa}$.

Körte (Pyrus communis) mintákat három évjáratból, integrált termesztésből kaptunk (M3. melléklet 6.-7. kép). Összesen öt fajtát vizsgáltunk. A 'Fétel apát' nevü körte a szerzetes, Abbé Fétel nemesítéséből keletkezett, 1866-ban Franciaországban. Nagy körte, hosszúkás formájú, kövér hassal. Héja sárgás, barna foltokkal tarkítva. Gyümölcshúsa szaftos, olvadó. A gyümölcs nagyon gyorsan megpuhul, ekkor belseje megbarnul, és már egyáltalán nem ízletes. Egyhe ízü és kevés savat tartalmaz. Augusztus végétől szeptember közepéig szedhető (Tóth, 2009). A 'Vilmos körte' a világ legelterjedtebb körtefajtája; Angliában már 1770-ben ismerték. Williams terjesztette el. A 'Vilmos körte' augusztus végén, szeptember elején érik, gyümölcse középnagy, kúpos vagy tojás alakú, héja szalma- vagy viaszsárga; zamatos íze elsőrendű asztali fajtává teszi. Gyümölcse 2 hétig eltartható, konzerv céljára kedvelik fehér húsát. A 'Vilmos körte ' árugyümölcsöseink egyik legfontosabb korai fajtája, üzemi ültetvényeink 6\%-át teszi ki, jelenlegi közszaporításunkban 8\%-kal szerepel (Tóth, 2009). A 'Conference' fajta Angliából származik (1894), az egész világon ismert és termesztett fő fajta. Magyarországon 1977 óta fő árufajta, de termesztési aránya máig kicsi. Optimális időben szedve (Magyarországon szeptember első hetében) a gyümölcsök jól tárolhatók, akár 6 hónapig. Évjáratonként nagy változékonyságot mutat a gyümölcs mérete. Tömege: 120-220 g között változhat. A gyümölcs alakja igen megnyúlt körte. Éretten zöldessárga alapszínű, túlnyomó részt hálózatosan vagy foltosan barna rozsdamázzal fedett, a héja száraz tapintású, vastag. Gyümölcshúsa sárgásfehér, olvadó, nagyon édes vajkörte. Feldolgozásra íz- és aromagazdagsága miatt nagyon jó, aszalásra, és ivólé-gyártásra kiváló. Alternanciára igen erősen hajlamos fajta. (Tóth, 2009). A 'Bosc kobak' (más néven Alexander) a XVIII. század elején keletkezett belga körtefajta. Az egész világon ismert, Magyarországon is a legnagyobb arányban termesztik. Szeptember végén szedhető, szakszerüen tárolva október és január között fogyasztható. A termés középnagy-nagy 
(180-280g), megnyúlt körte alakú, a kocsány felé elkeskenyedő. Alapszíne zöldessárga, de szinte teljesen barnás parával fedett, száraz tapintatú. Húsa fehér, olvadó, vajszerü, bő levü, gyengén kövecses, kellemesen füszerízü. Jól szállítható és kiválóan tárolható (Tóth, 2009). A 'Packham's Triumph' Ausztráliából származik. Régi fajta, de Európában csak az utóbbi évtizedekben népszerü.

\subsubsection{Időjárás}

A 2008-as évben meleg nyár volt, kevés csapadékkal és $41-42{ }^{\circ} \mathrm{C}$-os júliusi csúcshőmérséklettel. A nagy hőmérséklet megviselte a fákat és sok volt a napégett gyümölcs. Jelentős volt a Psylla pyri (levélbolha) által okozott károsodás. Az öntözés növelte a költségeket. A 2009-es évben a fagy elkerülte a virágzás időszakát. A gyümölcs növekedés időszakában gyakran esett, ezért a levélbolha kár nem jelentős. Az Erwinia amylovara (tüzelhalás) és a Venturia (varasodás) okozott kisebb problémákat. Két nagyobb jégeső károsította a gyümölcsösök nagy részét, ezért a betakarított gyümölcsök jelentős hányada valamilyen mértékben sérült volt. Az előbbieket leszámítva a 2009-es év szélsőségektől mentes volt. A szüntelenül változó és szélsőséges 2010-es időjárás meglátszott a többi évhez elmaradó gyümölcshozamban. A tél végi és március eleji erős hőmérséklet-ingadozás jelentős hatással volt a gyümölcsfákra. Az éjszakai fagyok hátrányosan befolyásolták a virágzást és a későbbi gyümölcsérést. A szokatlanul nagy esőzések miatt ugyan nem volt szükség öntözésre, de az idő kedvezett a gombák és baktériumok szaporodásának. (További időjárási adatok az M4. mellékletben találhatóak)

\subsubsection{Tárolás}

Azon minták esetében (meggy), ahol végeztünk tárolási kísérletet, ott 1 hónapig 2 , illetve $6^{\circ} \mathrm{C}$ on történt a tárolás hűtőkamrában, illetve hűtőszekrényben, a Központi Élelmiszertudományi Kutató Intézet Mikrobiológiai és Analitikai osztályain, folyamatosan monitorozva a hütés hömérsékletét. A mintákat - ha külön nincs jelölve az eredményeknél - minden esetben frissen, illetve két napon belüli tárolás után felhasználtuk a mérésekhez. 


\subsection{Vizsgálati módszerek}

\subsubsection{Fizikai vizsgálati módszerek}

\subsubsection{Gyümölcsminták előkészitése és tömegmérése}

A gyümölcsöket először csapvízzel, majd desztillált vízzel mostuk. Az MSZ 967-1:1982 (visszavont) szabvány szerint, tolómérce segítségével meghatároztuk 50db (meggy, cseresznye) illetve 30db (alma, körte) szélességét, a kocsányra merőleges irányban, kiszámítottuk az átlag szélességet és mértük a legnagyobb illetve legkisebb szélesség értékét is. A körte esetében hosszirányú mérést is végeztünk. Meghatároztuk (cseresznye és meggy esetében) maggal és mag nélkül 50 szem súlyát és ebből kiszámítottuk egy szem átlagos súlyát maggal és mag nélkül is. Meghatároztuk (alma és körte esetében) 30 darab súlyát és ebből kiszámítottuk az átlagos tömegeket.

\subsubsection{Kémiai vizsgálati módszerek}

\subsubsection{Gyümölcsminták elökészitése}

$5 \mathrm{~kg}$ mintából kb. $1 \mathrm{~kg}$ súlyú, lehetőleg optimális érettségü és hibátlan gyümölcsöt kiválogattunk, majd péppé aprítottuk. Ezt a pépet használtuk az oldható szárazanyag, titrálható sav és, polifenol tartalom meghatározására.

\subsubsection{Gyümölcsminták savtartalmának meghatározása}

A titrálható sav mérése a MSZ ISO 750:2001 (Gyümölcs- és zöldségtermékek titrálható savtartalmának meghatározása) szabvány szerint automata titrátorral történt. A megadott értékek pH 7-re titrálva, borkősavban számítva g/kg, valamint pH 8,1-re titrálva, citromsavra számítva, g/kg-ban értendők.

\subsubsection{Gyümölcsminták szárazanyagtartalmának meghatározása}

Az oldható szárazanyagot a MSZ EN 12143:1998 (Gyümölcs- és zöldséglevek oldható szárazanyag-tartalom mérése) szabvány szerint mértük $\mathrm{ABBE}$ refraktométerrel $20^{\circ} \mathrm{C}$ hőmérsékleten. A pépet gézen keresztül szürtük át és a szürletet vittük fel a műszer prizmájára.

\subsubsection{Gyümölcsök összes polifenol vegyületeinek mérése}

A polifenol-tartalom mérése a MSZ 9474-80 (Borok polifenoltartalmának meghatározása) szabvány szerint, spektrofotometriásan történt. A polifenol elemzéshez 10 g gyümölcspépet 40 
ml metanollal extraháltunk, egy éjjelen keresztül hütőszekrényben állni hagytuk, majd szürőpapíron szürtük. A továbbiakban ezt a metanolos szürletet használtuk a polifenol mérésére két párhuzamos extrakciót követően, összesen négy ismétlésben. A csapadékkiválás elkerülése érdekében a színreakció lejátszatásakor elöször vizet adtunk a metanolos extrakthoz, és csak utána a Folin-Ciocalteu reagenst, majd a 20\% nátrium-karbonátot. A mérés előtt az elegyet 1 óra hosszat sötét helyen állni hagytuk. Az összpolifenol tartalmat galluszsavval készített kalibrációs görbe alapján számítottuk ki. Az eredményt galluszsav-ekvivalensben adtuk meg, $\mathrm{mg} / \mathrm{kg}-\mathrm{ban}$.

\subsubsection{Meggy antocianin vegyületeinek HPLC mérése}

A meggymintákból 5 g-ot mértünk be, majd a kvarchomokkal kevert mintát 2x $10 \mathrm{ml} 2 \%$ ecetsavas $\mathrm{MeOH}-a$ al extraháltuk, kvantitative átmostuk egy Erlenmeyer-lombikba, majd 15 percig rázattuk. Ezután centrifugáltuk 15 percig, 10000 fordulaton. A felülúszót mikroszürőn keresztül leszürtük.

A komponensek HPLC-s elválasztását és mennyiségi meghatározását Waters kromatográfiás rendszerrel végeztük el. Az elválasztáshoz használt oszlop: Nucleodur Sphinx RP, (5 $\mu \mathrm{m}, 250$ mm x 4,6 mm), folyadékfázis: A: 1 \% hangyasav, B: metanol/víz/hangyasav (600/390/10). Az áramlási sebesség: 0,6 ml/perc volt. Az antocianinok mennyiségét $520 \mathrm{~nm}$-en mértük.

\subsubsection{Antioxidáns hatás / gyökfogó kapacitás mérése}

A szabadgyök befogó képesség mérése 2,2-difenil-pikrilhidraziddal (DPPH) (Fluka, Buchs, Switzerland) történt Brand-Williams és munkatársai (1995) módszerével. A higított metanolos kivonat $50 \mu$ l-ét összekevertük a küvettában $2 \mathrm{ml}$ metanolos DPPH oldattal. Majd $36^{\circ} \mathrm{C}$-on termosztálva, $517 \mathrm{~nm}$ hullámhosszon (5. ábra) 30 perc elteltével mértük a mintákban a vakhoz képest az extinkció csökkenését. A vak mintába szürlet helyett desztillált vizet helyeztünk. A kalibrációt Trolox oldattal készítettük. A gyökfogó aktivitást $\mu$ mol trolox/g nyersanyag mennyiségben fejeztük ki.

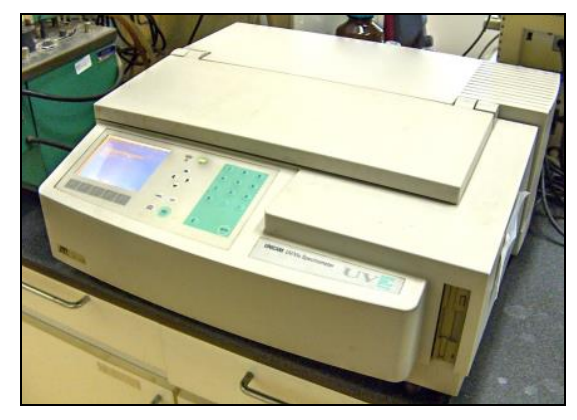

5. ábra: A mérésekhez használt Unicam UV-VIS spektrofotométer 


\subsubsection{Mikrobiológiai vizsgálati módszerek}

Elsősorban a gyümölcsfelületen lévő (epifita) mikrobiotát vizsgáltam, a megfelelő szabványokat alkalmazva. A vizsgálatokhoz ép, egészséges gyümölcsöket válogattunk. Két párhuzamos leoltást végeztünk minden esetben. Az eredmények megadásánál a telepképző egységek (tke) száma $1 \mathrm{~cm}^{2}$ gyümölcsfelületre vonatkozik.

\subsubsection{A gyümölcsök felületén lévö összes csíraszám meghatározása}

A mezofil aerob összes élőcsíraszám meghatározása az MSZ EN ISO 4833 szabvány alapján történt. Alma és körte esetében 3-3 gyümölcs felületét mostuk le $90 \mathrm{ml}$ hígító folyadékban (peptonvíz) 1 percig. Meggy és cseresznye esetén 10-10 db gyümölcs. Ezt követően 5 lépcsős

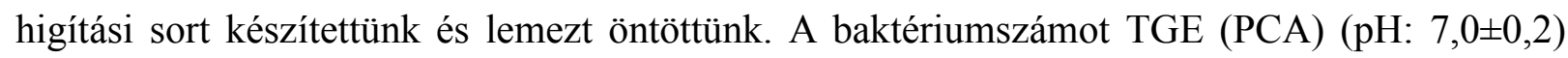
(MERCK) táptalajon $\left(30^{\circ} \mathrm{C}\right.$-on inkubálva) három nap elteltével értékeltük ki.

A pepton víz vagy „hígító folyadék” összetétele: 1,0 g pepton (Merck), 9,0 g nátrium-klorid $(\mathrm{NaCl})(\mathrm{Merck}) 1000 \mathrm{ml}$ desztillált vízben oldva, majd autoklávban sterilezve $121{ }^{\circ} \mathrm{C}$-on 20 percig.

\subsubsection{A gyümölcsök felületén lévö élesztö- és penészgomba meghatározása}

Élesztő- és penészgomba szám meghatározása az MSZ ISO 7954 szabvány alapján (lemezöntés ISO 7954 Chloramphenicol agarral ( $\mathrm{pH}:$ 6,6) (Biolab) 0,025g/l bengálrózsával (Fluka) kiegészítve történt, ugyancsak 5 lépcsős hígítási sorral, lemezöntéssel, amelyet 4-5 napos $25^{\circ} \mathrm{C}$ os inkubálás után értékeltünk. A különböző gyümölcsökböl ugyanannyit mostunk le, mint az összes élőcsíraszám meghatározása során. (M3 melléklet 8.kép)

\subsubsection{A gyümölcsök felületén lévő indikátor mikroorganizmusok meghatározása}

Az indikátor mikrobák közé tartoznak a kóliformok, az Escherichia coli, az Enterobacteriaceae család tagjai, valamint a Pseudomonas aeruginosa. Az Enterobacteriaceae szám meghatározása az MSZ ISO 21528-2 szabvány alapján történt (lemezöntés VRBG agarral (MERCK), inkubálás $37^{\circ} \mathrm{C}$-on 2 nap).

A kóliform- és az Escherichia coli szám meghatározását az MSZ 3640/18-79 és MSZ 36401979 szabvány alapján végeztük (lemezöntés Chromocoli agaron (pH: 7,4) (Biolab), inkubálás $37^{\circ} \mathrm{C}$-on 2 nap). A kromogén agaron az E. coli indigókék, a kóliformok lazacszínü telepeket képeznek. 
A Pseudomonas aeruginosa szám meghatározása az MSZ 3640/7-80 szabvány alapján történt (felületi szélesztés Cetrimid agaron (Merck). Inkubálás (48 óra $35^{\circ} \mathrm{C}$-on) után a jellegzetes telepek sárgás-zöldek és UV fény alatt fluoreszkálnak.

\subsubsection{A gyümölcsök felületén lévö patogén mikrobák meghatározása}

A Listeria monocytogenes meghatározása az MSZ EN ISO 112900:1998 szabvány alapján történt. Az egyes gyümölcs mintákból annyi darabot vettünk ki, amennyi 25 g-nak felelt meg. A gyümölcsöket $225 \mathrm{ml}$ fél-Fraser (Merck) elődúsító folyadékban megmostuk, majd a folyadékot inkubáltuk (24 óra, $30^{\circ} \mathrm{C}$-on); elődúsítás után Fraser dúsító folyadékba oltottuk át, majd újabb inkubálás után (24 óra, $30{ }^{\circ} \mathrm{C}$-on) ALOA (Ottavani \& Agosti) kromogén agarra (Biolab) szélesztettük. A L. monocytogenes türkizkék telepeket képez opálos udvarral 24 órás $37^{\circ} \mathrm{C}$-os inkubálás után. A pozitív eredményt API Listeria teszttel (6. ábra) erősítettük meg.

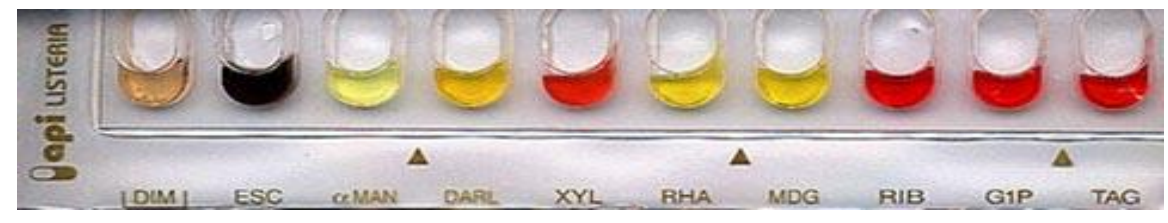

\section{6. ábra: API Listeria biokémiai teszt csík}

A Salmonella spp. meghatározása az MSZ EN ISO 6579:2002 szabvány alapján történt. Az egyes mintákból 25 g-nak megfelelő gyümölcsöt vettünk ki. A gyümölcsöt 225 ml hígító folyadékban megmostuk majd a mosófolyadékot inkubáltuk (18 óra, $37^{\circ} \mathrm{C}$-on). Elődúsítás után Rappaport-Vassiliadis (Merck) dúsító folyadékba oltottuk át, majd újabb inkubálás után (24 óra, $44{ }^{\circ} \mathrm{C}$-on) XLD kromogén agarra (Merck) szélesztettük. A Salmonella erős fekete színü telepeket képez az XLD agar felületén.

Az Enterobacter sakazakii meghatározása az ISO /TS 22964:2006 (IDF/RM 210:2006) szabvány alapján történt. Az egyes gyümölcsmintákból 10 g-nyi mennyiségeket mértünk be. Pufferolt peptonvizes mosás után $37{ }^{\circ} \mathrm{C}$-on 18 órán keresztül inkubáltuk, majd módosított lauril-szulfátos tripton levesbe pipettáztunk az elődúsított mintából $0,1 \mathrm{ml}$-t. 24 órás, $44{ }^{\circ} \mathrm{C}$-on történő inkubálás után vankomicines szelektív agarra szélesztettük, s újabb $44{ }^{\circ} \mathrm{C}$-os, 24 órás inkubálás után értékeltünk. Az Enterobacter sakazakii törzsek a kromogén agaron türkíz zöldek, körülöttük feltisztulási zónával. További megerősítés TSA agaron, illetve API 20E Enterobacter sakazakii teszttel lehetséges. 


\subsection{Alkalmazott statisztikai módszerek}

A vizsgálatok kiértékeléséhez a Microsoft Excel 2003-as program bővített csomagját használtam, a disszertációban szereplő, paraméteres statisztikai próbák, és a regresszió analízis, illetve a többi ábra elkészítése során is ezt használtam. A hierarchikus klaszter analízishez a statistXL 1.8 ingyenesen letölthető próbaverzióját használtam (Gaál, 2004).

A bio és integrált termesztési mód összehasonlításánál a kétmintás t-próbát alkalmaztam, amely a paraméteres próbák közé tartozik, és azt vizsgálja, hogy két külön mintában egy-egy valószínűségi változó átlagai egymástól szignifikánsan különböznek-e. Paraméteres próbát végzünk, ha az alapsokaság eloszlásának valamely paraméterére (várható érték, szórás) vonatkozó feltevésünkről az $\mathrm{n}$ elemű véletlen mintán mért adatok, illetve az ezekből az adatokból számolt egyetlen érték, a próbastatisztika számított értéke alapján döntünk (HarnosLadányi, 2005). Mindenhol a 95\%-os konfidencia szintet vettem alapul. A megbízhatósági szint a statisztikai döntés helyességének megbízhatóságát fejezi ki, míg a szignifikancia szint a hibás döntés valószínüségét (Szücs, 2004). A próba feltételeként megadott normalitásvizsgálat elvégzésén kívül F-próbával ellenőriztem a két alapsokaság szórásnégyzetének azonosságát (Kemény, 2002). A próbastatisztika során megállapított eredmények statisztikailag igazolhatóan eltérhetnek 5\%-os szignifikancia szinten.

A polifenol-tartalom és az antioxidáns kapacitás közötti kapcsolat elemzésekor, e két mennyiség közötti kapcsolat vizsgálatára regresszió- és korrelációelemzést (Baráth, 1996) alkalmaztam. A pontdiagramok (korrelogram, Tóthné, 2011) alapján lehet eldönteni, hogy milyen kapcsolat feltételezhető a két vizsgált tulajdonság alapján. Az elkészített ábrákon pozitív lineáris sztochasztikus kapcsolat tételezhető fel a polifenol tartalom és az antioxidáns kapacitás között (ennek függvénye: $y=a+b * x$ ). Ennek megfelelően lineáris függvényt illesztettem a két mennyiségi változóra. A program a determinációs együtthatót $\left(\mathrm{r}^{2}\right)$ adja meg közvetlenül. A determinációs együttható $\left(\mathrm{r}^{2}\right)$ azt mutatja, hogy a változók egymás szórásának hány \%-át magyarázzák (Tóthné, 2011). Ebből gyökvonással számolható a lineáris kapcsolat szorosságát mutató korrelációs együttható (r). A korrelációs együttható értéke annál szorosabb kapcsolatot feltételez, minél közelebb áll abszolút értékben az 1-hez. A mutató megbízhatóságát minden esetben ellenőriztem az adott szabadságfok mellett kikeresett kritikus értékhez való összehasonlítással. A kapott korrelációs együttható értéke minden esetben nagyobb volt, mint a kritikus értékhez tartozó r* érték. 
Az egyes gyümölcsök különböző mért jellemezőit klaszteranalízis segítségével csoportosítottam. A klaszteranalízis tetszőleges objektumok különböző osztályokba sorolását lehetővé tevő módszer. A hierarchikus klaszterezési eljárások fő jellemezője az, hogy fokozatosan csökkenti a csoportok számát, úgy, hogy minden lépésben összevonja a két legközelebbi (egymáshoz leginkább hasonló) csoportot. Annak eldöntésére, hogy mikor tekintsünk legközelebbinek két csoportot, a döntési függvény vagy összekapcsolási módszer (linkage method) szolgál (Szücs, 2004). A dolgozatban alkalmazott hierarchikus klaszteranalíziseknél az összekapcsolási módszer a legközelebbi szomszéd (nearest neighbour). Ezt a döntési kritériumot alkalmazva először minden csoportpár esetén meghatározzuk az egymáshoz legközelebbi elemeik távolságát, majd azt a két csoportot vonjuk össze, amelyek esetén az előbbi távolság minimális. A változók hierarchikus osztályozása során gyakorlatilag hasonló kérdéseket szeretnénk megválaszolni, mint a fökomponens vagy faktoranalízis során, vagyis, hogy az egyes elemek egy vagy több paramétere alapján - köztük lévő összefüggések alapján milyen csoportokba lehetne őket besorolni. 


\section{Eredmények}

A Jedlik Ányos pályázat célja a ökológiai és integrált gyümölcstermesztést megalapozó biológiai alapok fejlesztése és technológiák kidolgozása volt. Az éghajlatváltozással együtt járó extrém, föként a mezőgazdaságot sújtó hatások elleni küzdelem központi kérdéssé vált a világ élelmiszer termelésében. Ezáltal megnövekedett a fajta kiválasztásának és a leghatékonyabb beavatkozás fontossága azért, hogy az ültetvények produktivitását és a termény minőségét hosszútávon biztosítani tudják. A pályázatban számos magyarországi ültetvény és tudományos központ vett rész, melyek nagyszámú vizsgálatokat és fajtakísérleteket végeztek el a fenti cél érdekében.

A három év (2008-2009-2010) során a következő gyümölcsök mikrobiológiai és analitikai vizsgálatait végeztem el: meggy, cseresznye, alma, körte fajták esetében. Elsődleges szempont volt a különböző termesztési módok, évjárat és fajták közötti különbség tanulmányozása illetve a vizsgálatok során kapott paraméterek összehasonlítása. A projekt során előfordult - részben az időjárási viszonyok, részben szállítmányozási és koordinációs körülmények - miatt, hogy nem minden évben kaptunk egy adott fajtából, évjáratból vagy termesztési módból, mégis a vizsgálatok a nagy mintaszámra való tekintettel reprezentatívnak tekinthetőek.

\subsection{Gyümölcsök áruértékét befolyásoló tényezők}

\section{TÖMEG, MÉRET}

\subsubsection{Meggy áruértéket befolyásoló tényezők}

A kutatómunka során összesen 3 évjáratban (2008-2010) határoztam meg 15 fajta meggy fizikai paramétereit. Évenkénti (7. ábra) illetve 3 évi átlag gyümölcsméretét (8. ábra) (magasság, szélesség) és átlagos gyümölcstömeget (9. ábra) vizsgáltam. A gyümölcs tömegét és méretét befolyásolja az érettségi állapota. A kutatásba bevont meggy minták paramétereinek mérése érett állapotban történt. A gyümölcs mérete szoros összefüggésben vannak a gyümölcs tömeggel. Az elvégzett klaszteranalízis (10. ábra) is megerősíti, hogy a 'Cigány' meggyek az átlagnál kisebb gyümölcstömeggel rendelkeznek. Az 'Oblacsinszka' és a $V N$ megyek szintén a kisebb méretü és tömegü fajták közé tartoznak. A nagyobb méretű és tömegű megyek az 'Érdi bőtermö', 'Debreceni bötermö' és a 'Kántorjánosi 3' fajták. Míg a 'Cigány' meggyek 
átlagtömege 3,8g körül mozgott, addig a 'Debreceni bötermö’ meggy gyümölcstömege mintegy kétszerese volt. Drake és Fellman (1987) szerint a gyümölcsminőség mellett a méret is fontos tényező a fogyasztóknak, mert a legtöbb vásárló inkább a nagyobb gyümölcstömeggel rendelkező terméket vásárolja a meggy esetében. Egy 2002-es átfogó kereskedelmi tanulmány szerint a 24 mm átmérőjü vagy nagyobb meggy vagy cseresznye „vásárlásra érdemes” termék a megkérdezett fogyasztók szerint (Omeg \& Omeg, 2005). Predieri és munkatársai szerint (2004) a legalább 25mm-es átmérővel rendelkező meggy illetve cseresznye áruértéke a legjobb. Nem találtam különbséget a gyümölcs tömegben és méretben a bio és integrált termesztési módok között. Az eredmények alapján a fajta hatása erőteljesebb, mint az évjáraté vagy a termesztési módé. Looney és munkatársai (1996) tanulmánya szerint a fajta meghatározó a gyümölcs méretének kialakításában.

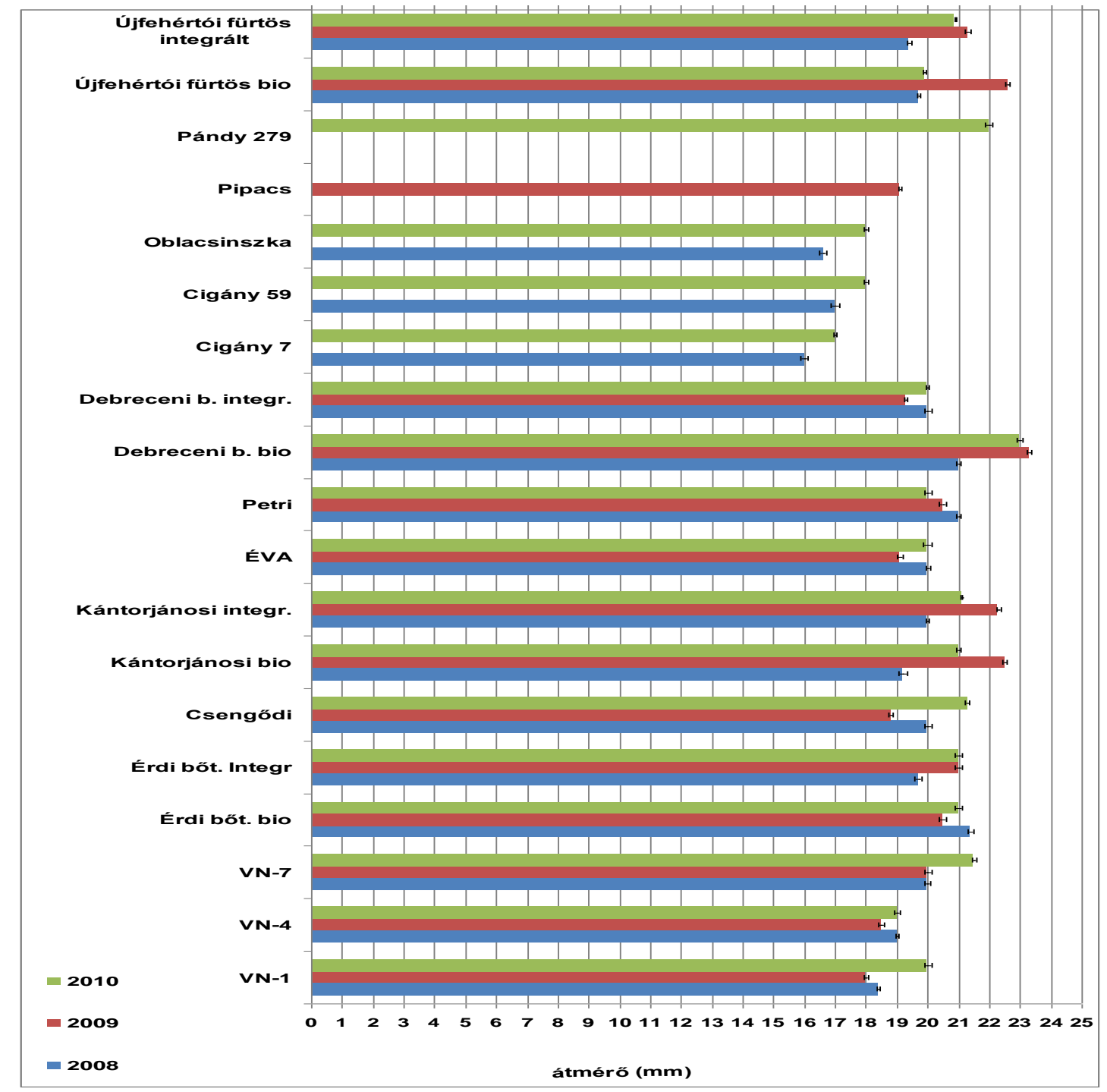

7. ábra: Vizsgált meggy minták évenkénti gyümölcsmérete 


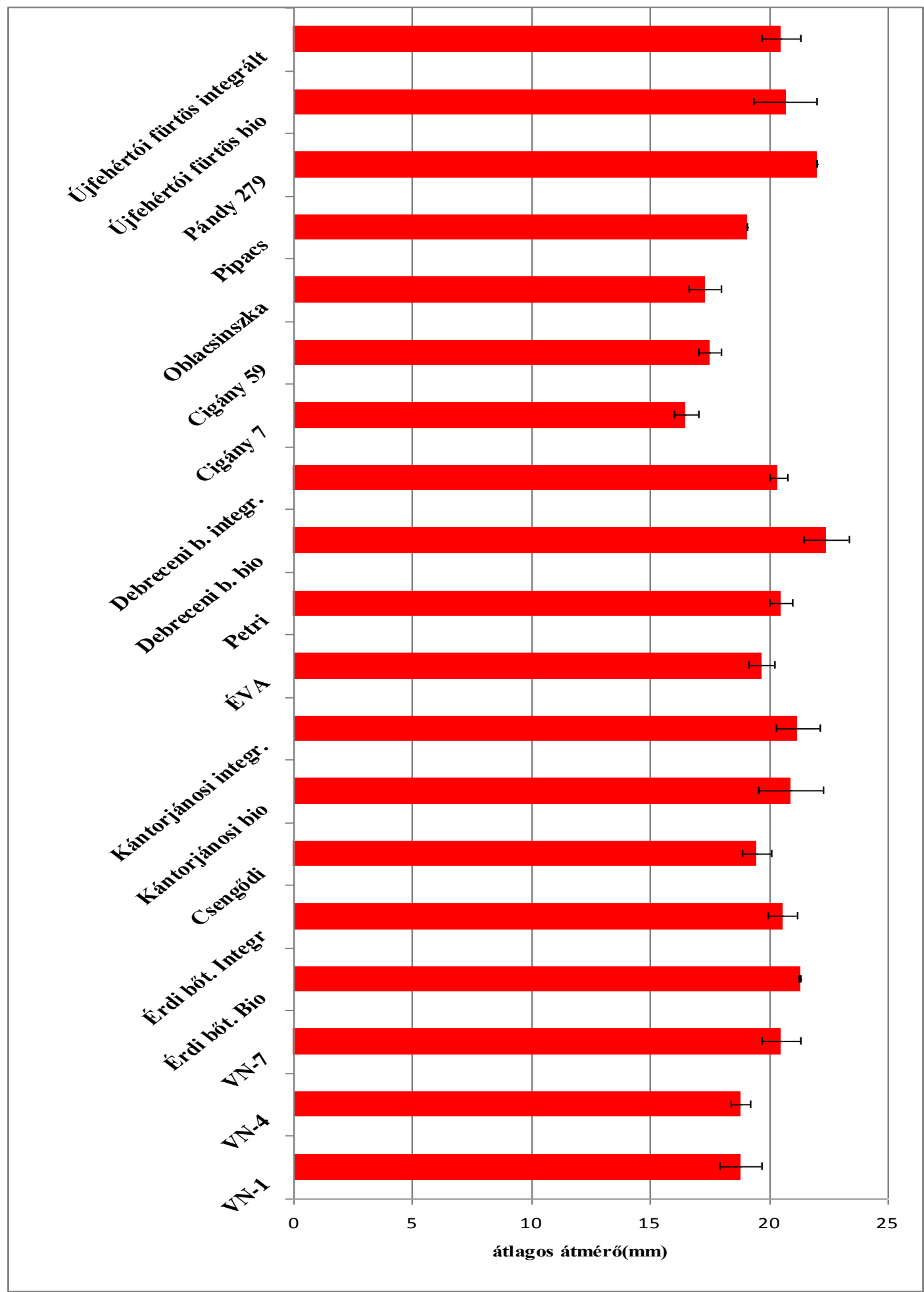

8. ábra: Vizsgált meggy minták átlagos gyümölcsmérete 


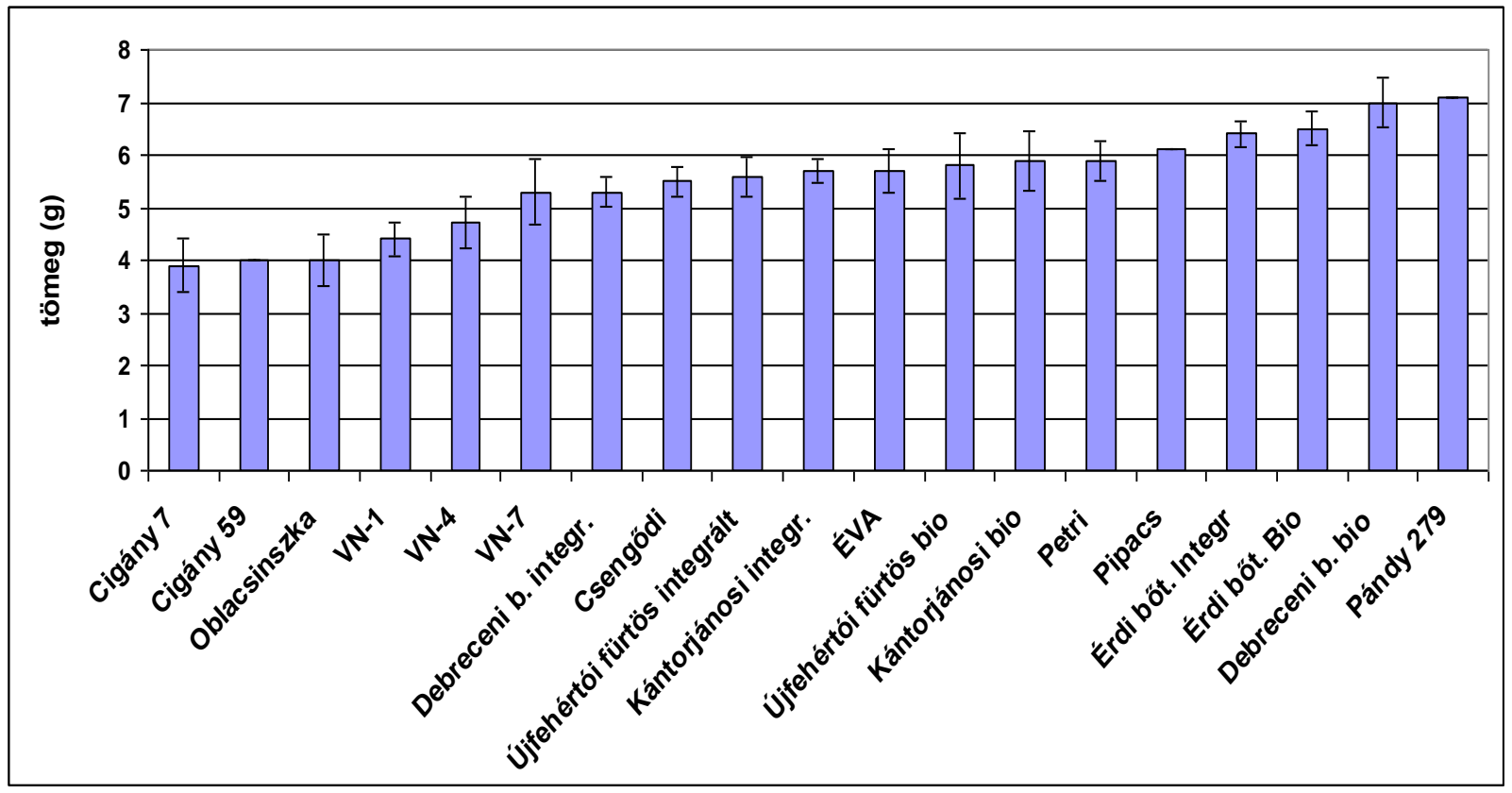

9. ábra: Vizsgált meggy minták átlagos gyümölcstömege

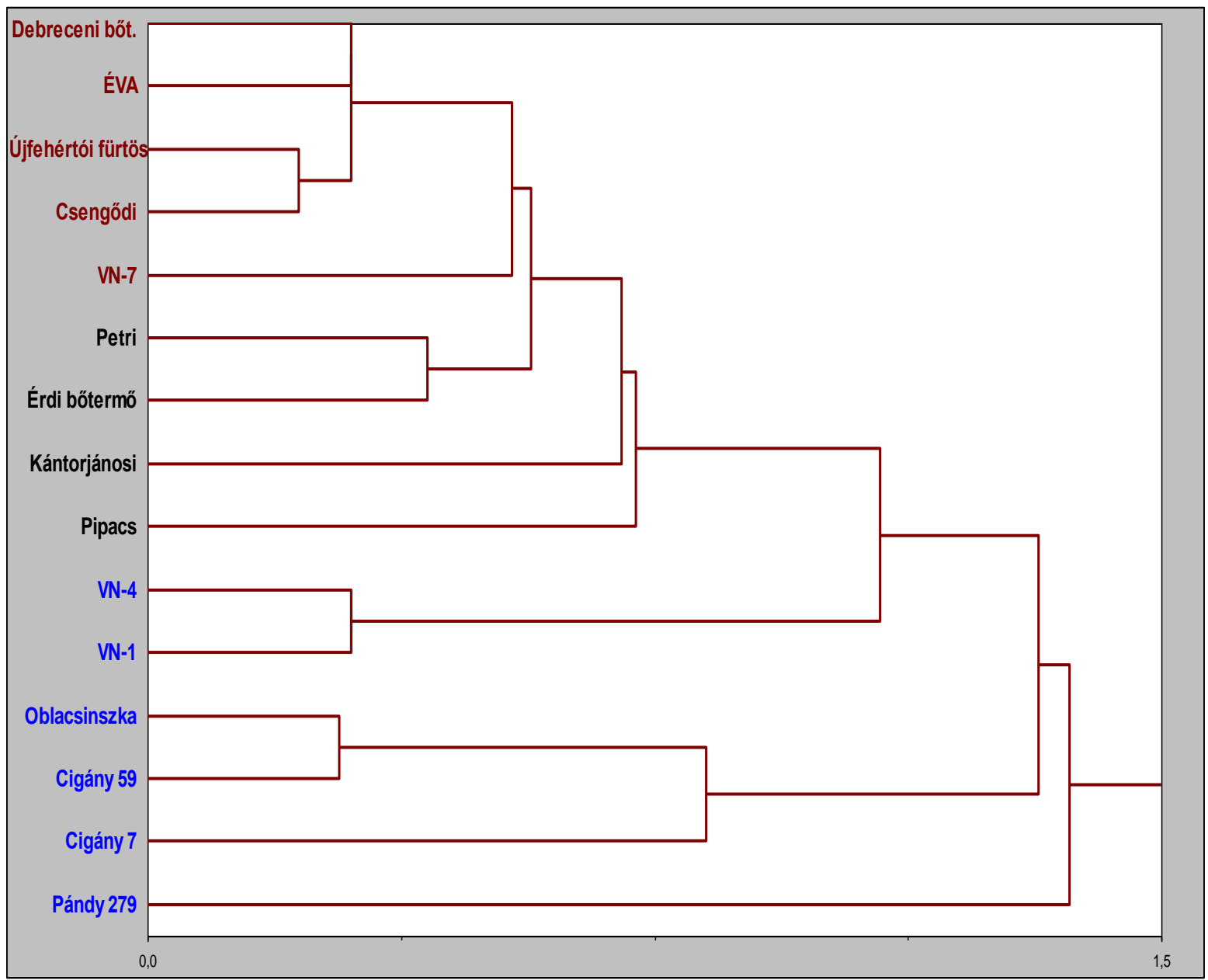

10. ábra: meggyfajták csoportosítása gyümölcstömeg és méret alapján alapján hierarchikus $\underline{\text { klaszteranalízissel }}$ 


\subsubsection{Cseresznye áruértékét befolyásoló tényezők}

Cseresznye mintákat három évjáratban követtem nyomon (2008-2010). A mintákat érett, egészséges állapotban vizsgáltam. Megállapítható, hogy a gyümölcs mérete és súlya leginkább a fajta függvénye. Legnagyobb gyümölcstömege a 'Regina' fajtának volt (12. ábra). Cseresznye esetében csak integrált termesztési módból származó minták álltak rendelkezésre.

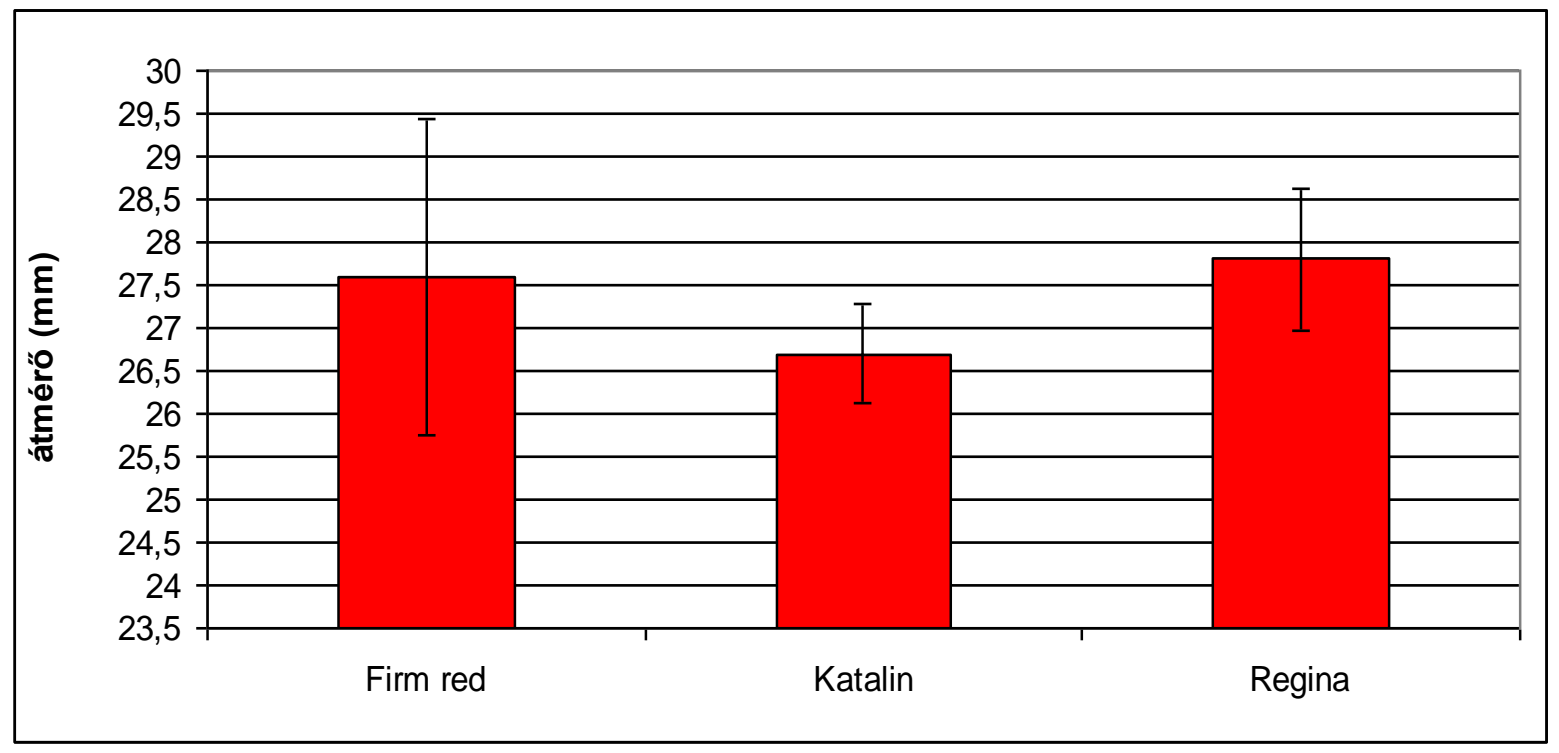

11. ábra: Integrált termesztésủ cseresznye fajták átlagos átmérője

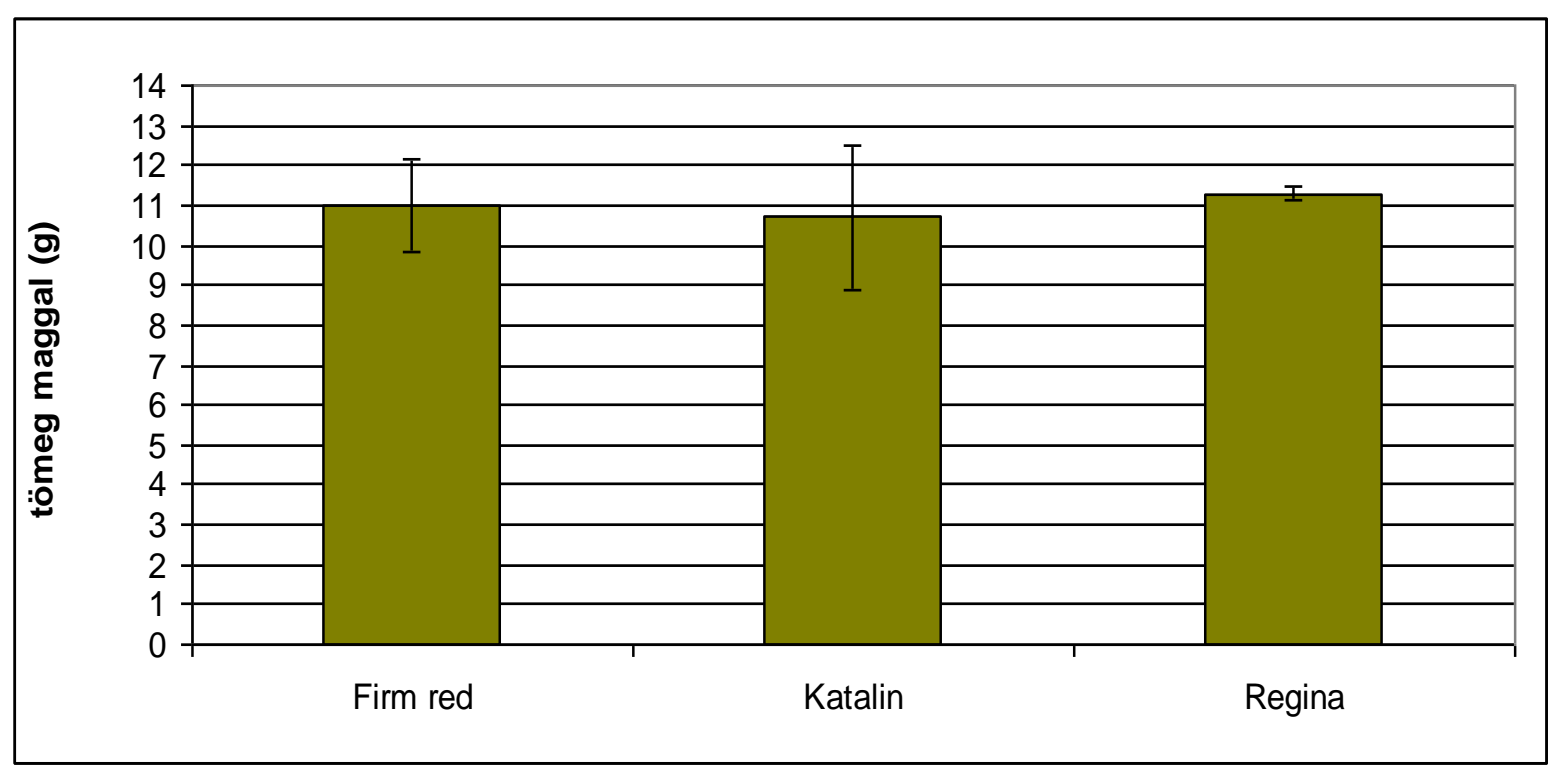

12. ábra: Integrált termesztésű cseresznye fajták átlagos tömege maggal 


\subsubsection{Alma áruértéket befolyásoló tényezők}

Az alma gyümölcstömege leginkább fogyasztói szempontból jelentős, ipari feldolgozását nem befolyásolja. A három év során (2008-2010) megmértem a vizsgálatba bevont almák méretparamétereit (13-14. ábra) (magasság, szélesség, vastagság) és gyümölcstömegét. A gyümölcstömeget számos körülmény befolyásolja - időjárás, fajta, tápanyagellátás. A rendelkezésre álló nagyszámú adatból összehasonlítást végeztem, elsősorban a fajtát és a termesztési módot vettem figyelembe, mint lehetséges elsődleges differenciáló tényező.

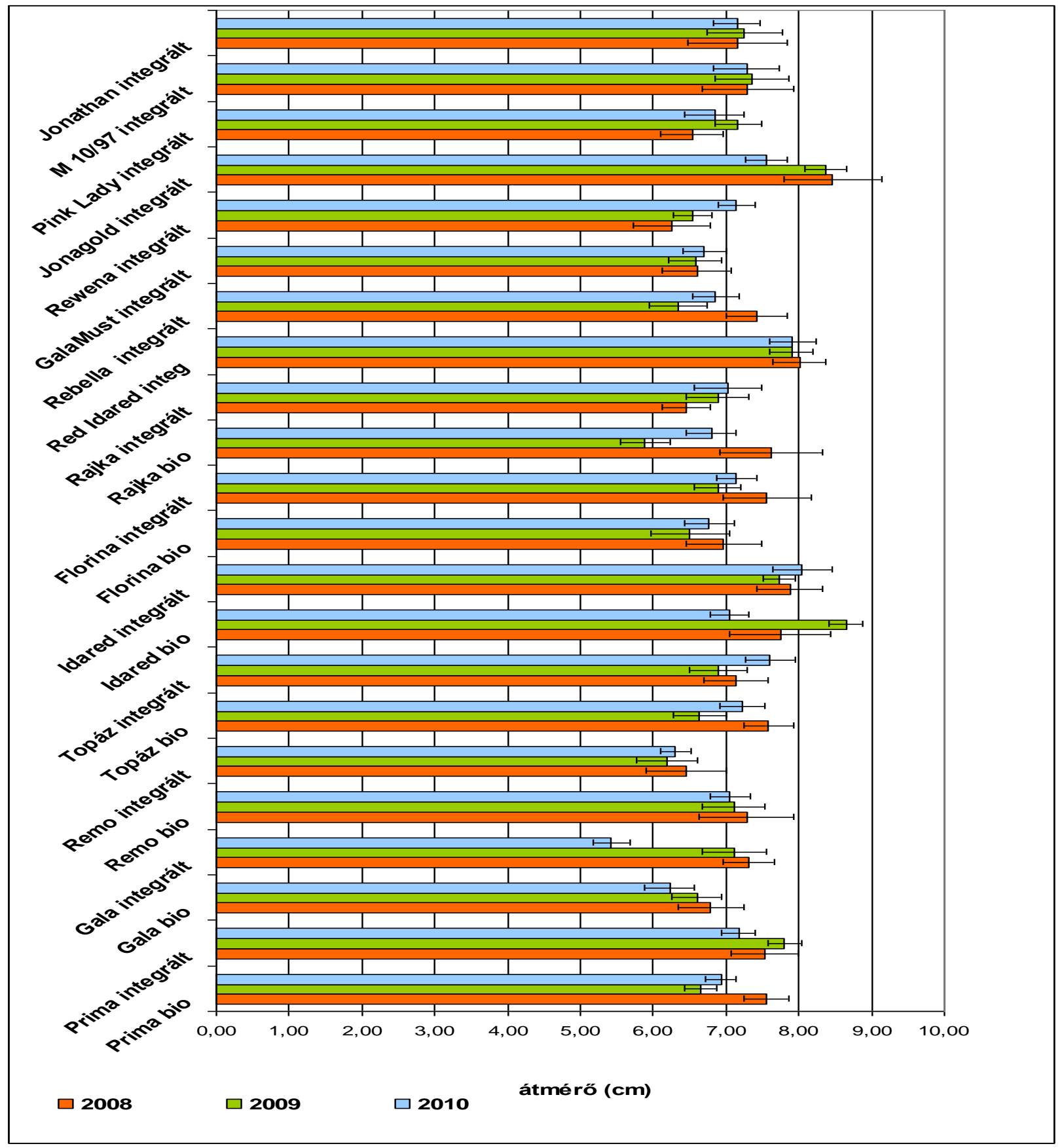

13. ábra: Vizsgált almafajták évenkénti mérete fajtánként figyelembe véve a termesztési módot $\underline{\text { is (2008-2009-2010) }}$ 


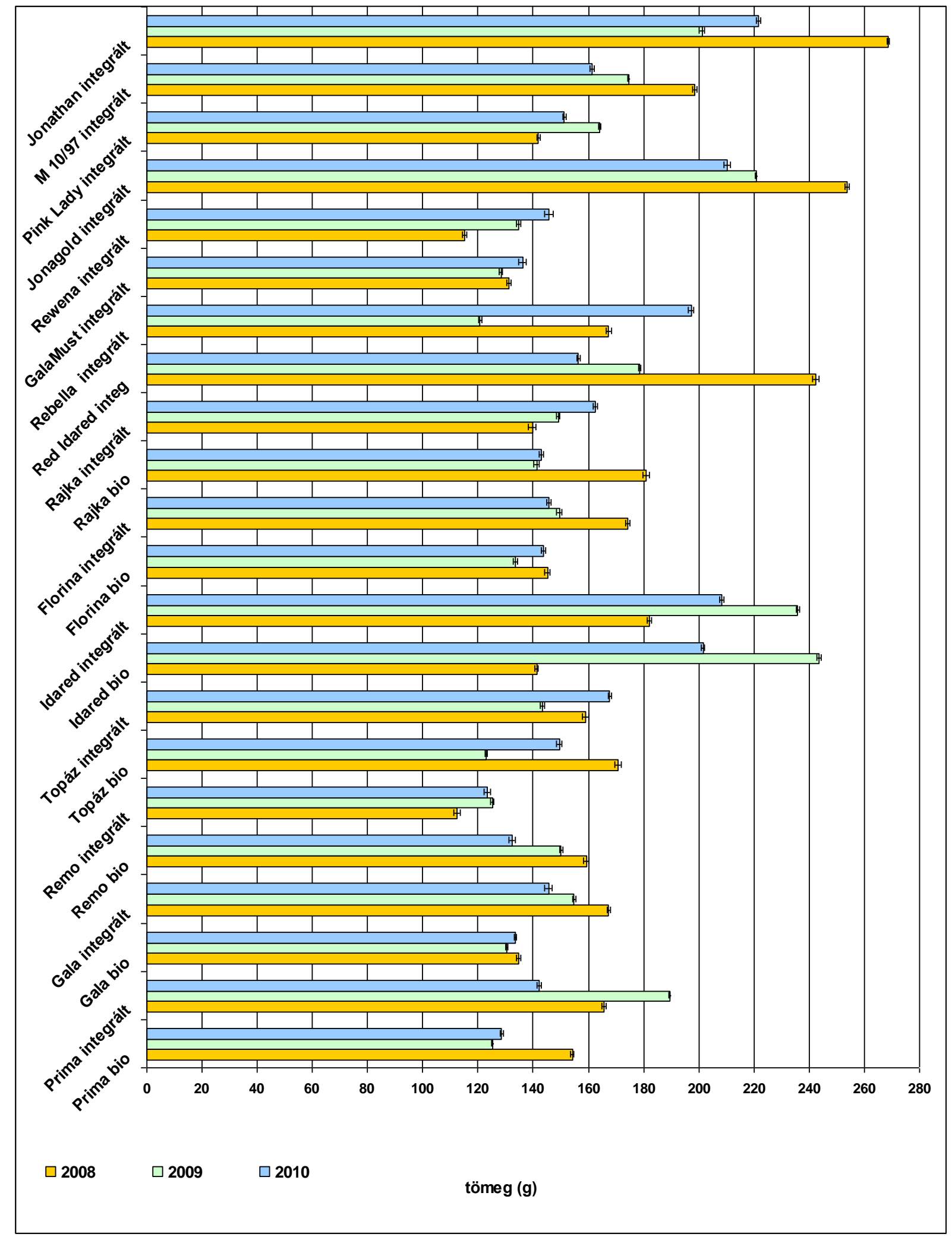

14. ábra: Vizsgált almafajták gyümölcstömege fajtánként, figyelembe véve a termesztési módot is. $(2008-2009-2010)$ 
Az öklógiai és integrált termesztési módot tekintve a gyümölcstömegben és méretben érzékelhető különbség van. Az ökológiai termesztésű gyümölcsök kisebbek, de nem szignifikánsan ( $\mathrm{p}<0,05)$, a 'Remo' fajta kivétel. Amarante és munkatársai (2008) ökológiai és integrált termesztésű 'Gala' és 'Fuji' alma tömegének vizsgálata alapján a bio almák tömegét szignifikánsan kisebbnek találta; valószínüsíthető a kisebb sejtméret és a kevesebb intracelluláris hely miatt, amely összefügg az organikus termesztésủ almák kisebb $\mathrm{P}, \mathrm{Ca}, \mathrm{Mg}, \mathrm{K}$ és N tartalmával is, méréseik szerint. Róth és munkatársai (2007) tanulmánya szerint az ökológiai termesztésű almák kisebb gyümölcstömeggel és mérettel rendelkeznek. A háromévi átlag gyümölcstömeg és átlag méret korrelációban van egymással (15. ábra). Klaszter analízissel is elkülönül egymástól a bio és integrált termesztésü csoport (16. ábra) a 'Rajka' bio és az 'Idared' integrált kivételével.

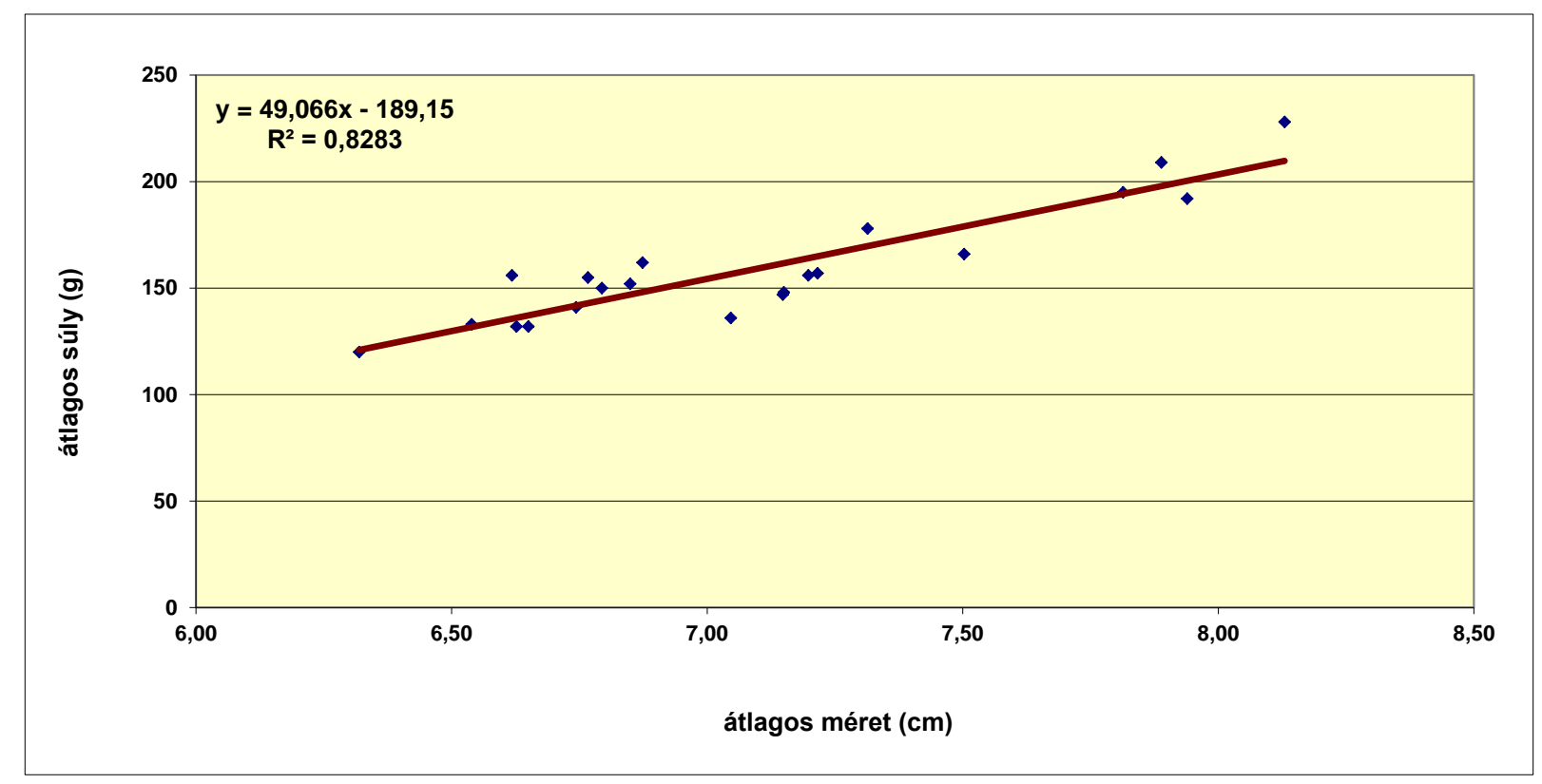

15. ábra: almaminták 3 évi átlag tömegének és méretének szoros korrelációja 


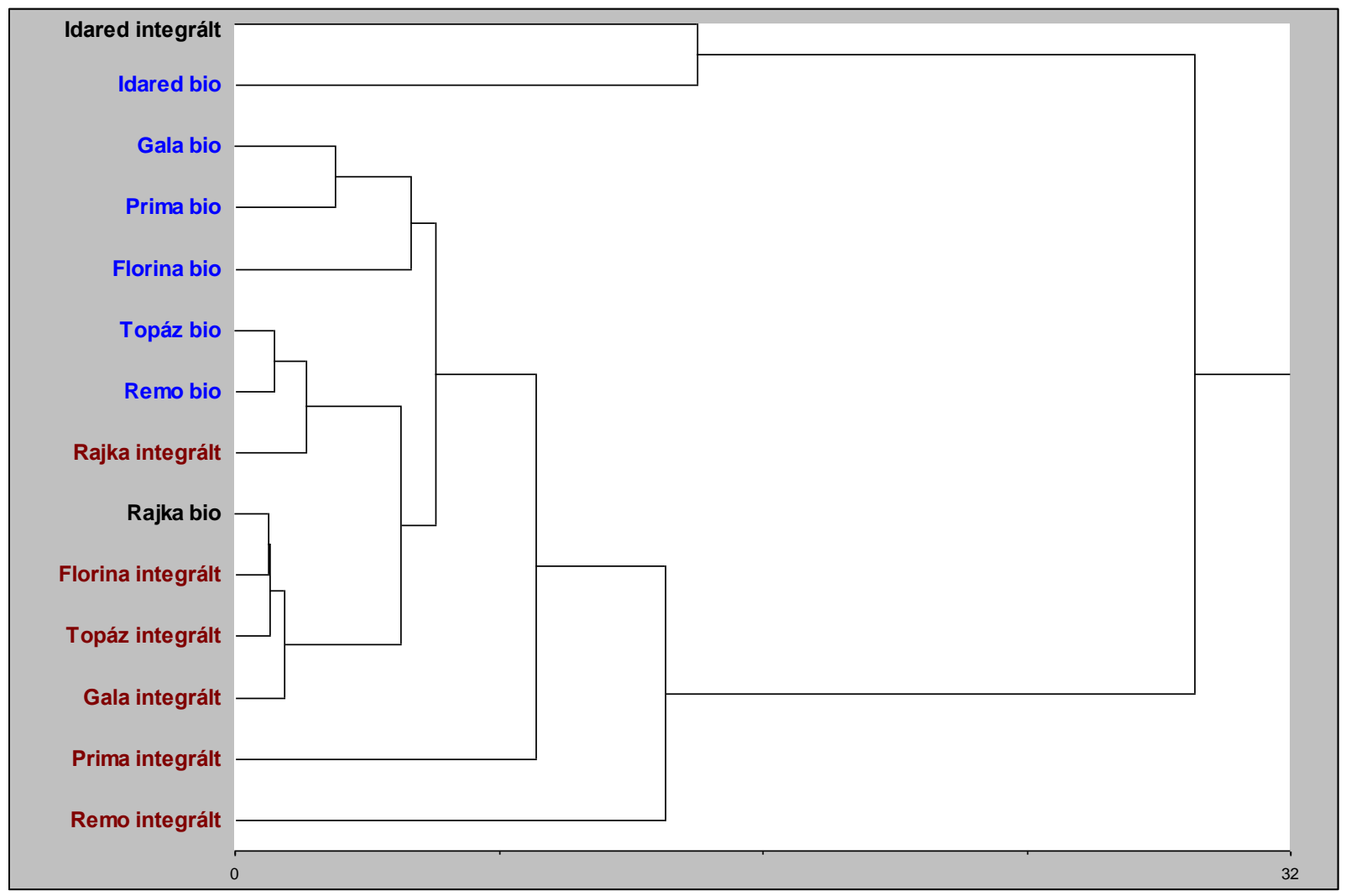

16. ábra: Almafajták csoportosítása tömegük alapján klaszteranalízissel a termesztési módot is figyelembe véve 


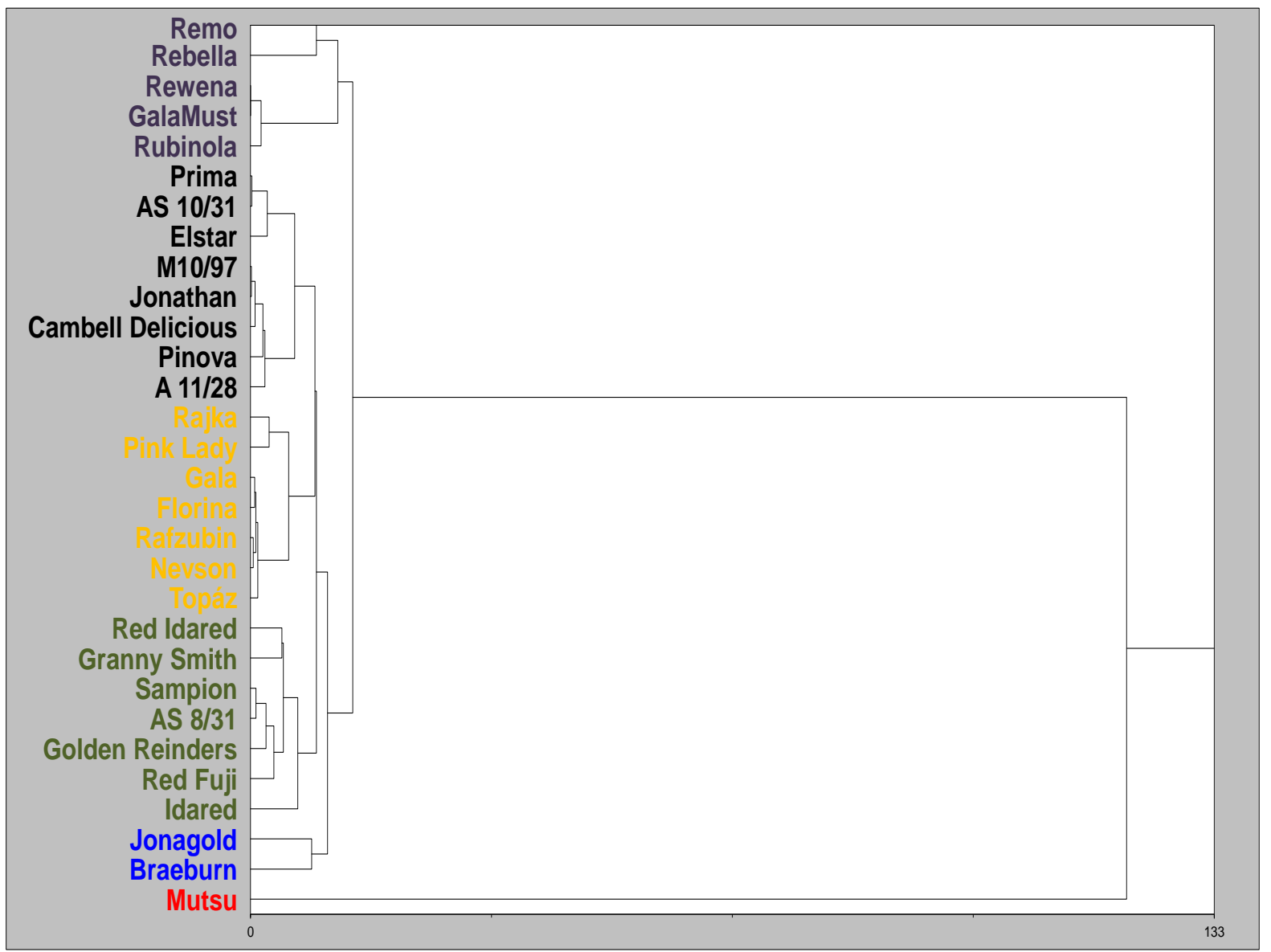

17. ábra: Almafajták csoportosítása tömegük és méretük alapján hierarchikus klaszteranalízissel

Hierarchikus klaszteranalízis segítségével további csoportosítást végeztem (17. ábra). A vizsgálat célja az egyes fajták közötti különbség megállapítása volt. A klaszter analízis alapján méret és tömeg szerint összesen hat csoportot lehet elkülöníteni. A legnagyobb a 'Mutsu' fajta, amely elkülönül a többi fajtától. A 'Mutsu' alma a 'Golden Delicious' és az 'Indo' fajták keresztezéséből született. Az 'Indo' fajták őse az 'White Winter Pearmin' nagyméretü világos angol almafajta, eredete egészen az 1200-as évekig nyúlik vissza. Szintén nagyméretü almák a 'Braeburn' és 'Jonagold' almák, melyek szintén nagyméretü almák keresztezéseiből születtek. A 'Jonagold' alma a 'Golden Delicious' és a 'Jonathan' alma keresztezéséböl született. A 'Jonathan' alma egy igen régi- az 1700-as évek elején felfedezett - amerikai almafajta, igen nagymérettel. Alakja és mérete nagyon hasonló a mai Jonathan almához. A harmadik csoportban is nagyobb méretüek találhatóak, mindegyik a 'Golden Delicious' fajta leszármazottja vagy mutánsa. A hatodik csoportban találhatóak a legkisebb tömegü és méretű almák. A mérések és a hierarchikus klaszteranalízis megerősítette, hogy a fajta tulajdonságok alapvetően befolyásolják a fizikai paramétereket, szinte függetlenül a termesztési módtól, azonban nem minden esetben egyértelmüen, emellett jelentős hatása van az évjáratnak is. 


\subsubsection{Körte áruértékét befolyásoló tényezők}

Körte minták vizsgálata három évjáratból és csak az integrált termesztési módból történt. A mérések alapján a három évjáratra vonatkozóan a 'Vilmos' körte a legkisebb a vizsgált fajták közül. Az irodalomban megadott gyümölcsméretek (Hudina \& Stampar, 2005) általában nagyobbak. Legnagyobbak a 'Fétel apát' és 'Bosc kobak' fajták. (18.-19. ábra).

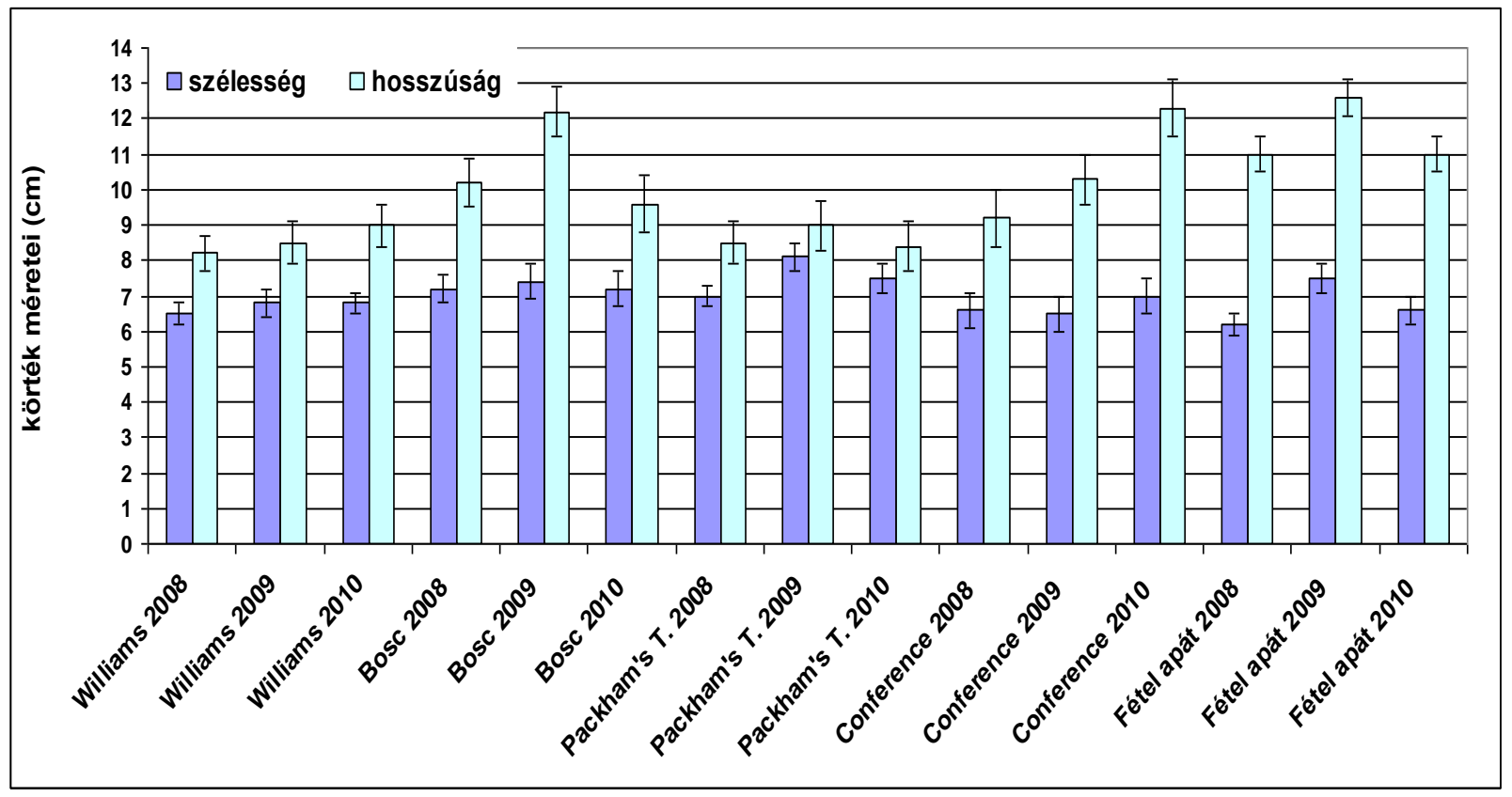

18. ábra: Körték évjáratonként mért szélessége és hosszúsága

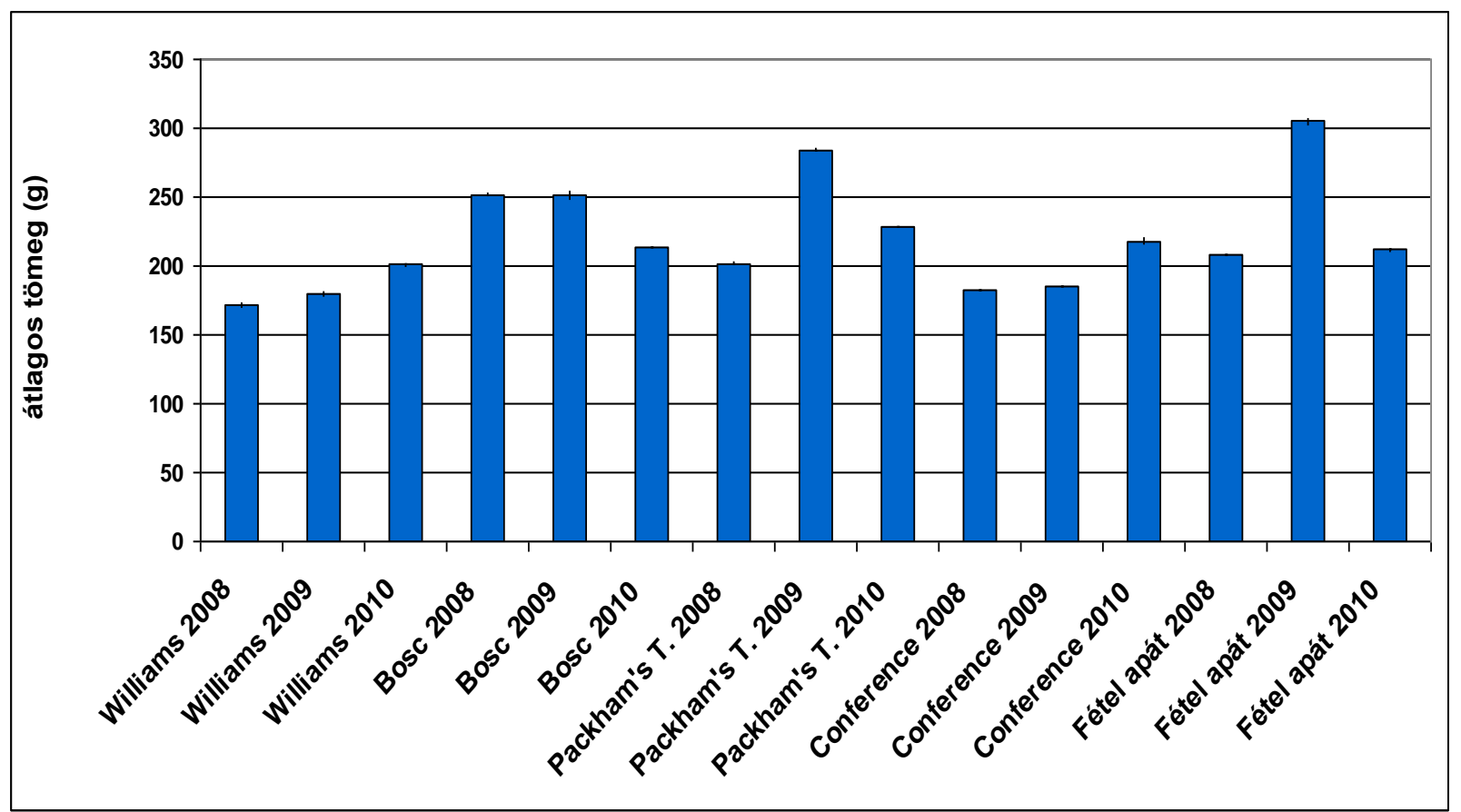

19. ábra: Körték évjáratonként mért tömege 


\subsection{Gyümölcsök felhasználási értékét befolyásoló beltartalmi}

\section{összetevők}

Mikrobiológia, SAV-ÉS SZÁRAZANYAGTARTAlom

\subsubsection{Mikrobiológiai vizsgálatok}

\subsubsection{Meggy mikrobiológiai vizsgálata}

A három éves (2008-2009-2010) átfogó vizsgálatok alatt 15 meggy fajta vizsgálatára került sor. A minták közül egyben sem volt kimutatható Salmonella, Listeria és Enterobacter sakazakii baktérium. A kóliform baktériumok szórványosan fordultak elő a gyümölcs felületén (2009-ben bio-termesztésü 'Ujjfehértói fürtös' és 2010-ből bio-termesztésü 'Kántorjánosi 3' és 'Debreceni bötermö’) a meghatározási limit környékén $\left(10 \mathrm{tke} / \mathrm{cm}^{2}\right)$. E. coli jelenléte nem volt kimutatható a meggy minták felületén, kivéve egy esetben csak (Újfehértói fürtös bio, 2010-ből), mely a kimutatási határon volt $\left(10 \mathrm{tke} / \mathrm{cm}^{2}\right)$. Pseudomonas aeruginosa szintén egy esetben volt kimutatható a Petri fajta felületén $\left(10\right.$ tke $\left./ \mathrm{cm}^{2}\right), 2009-b e n$. Az egyes meggy minták felületére jellemző mezofil aerob összcsíraszámot és a penész- és élesztőgomba számot bizonyos mértékben meghatározta a termesztés módja, az évjárat és a termesztési helye. Erre kerestem a pontos választ a különböző összehasonlításokkal.

\section{Mikrobiális szennyezettség gyakorisági eloszlása}

A megvizsgált meggy minták mikrobiális szennyezettségét lebontva az egyes fő szennyezőkre, külön az integrált és ökológiai termesztési módnál (aerob összcsíraszám, penészgomba, élesztőgomba) a gyakorisági diagramokon jól látszanak az egyes eloszlások. Az aerob összcsíraszám a minták felületén $10-10^{6} \mathrm{tke} / \mathrm{cm}^{2}$ (20. ábra) között jellemző, de a minták többségén $10^{3}-10^{5}$ tke/ $\mathrm{cm}^{2}$ mennyiségben fordul elö. Mind az ökológiai, mind az integrált termesztési mód az aerob összcsíraszám esetében a Gauss-féle eloszlást követi - a minták nagy részére a $10^{3}-10^{5}$ tke/cm ${ }^{2}$ jellemző. Az integrált termesztésű gyümölcsök szennyezettség eloszlásai szélesebb sávot mutatnak, mint az ökológiai termesztésű gyümölcsöké. Mind az ökológiai, mind az integrált termesztésnél a penészgomba szennyezettség a legtöbb mintánál $10^{4}$ tke/ $\mathrm{cm}^{2}$ (21. ábra). Az élesztőgombák előfordulása hasonló volt mindkét termesztési mód esetében (22. ábra), $10^{1}-10^{5}$ tke/ $\mathrm{cm}^{2}$ volt jellemző, de az integrált termesztési mód esetében csak néhány minta rendkívül szennyezett volt, míg ilyen ökológiai termesztésűeknél nem is fordult elö. 


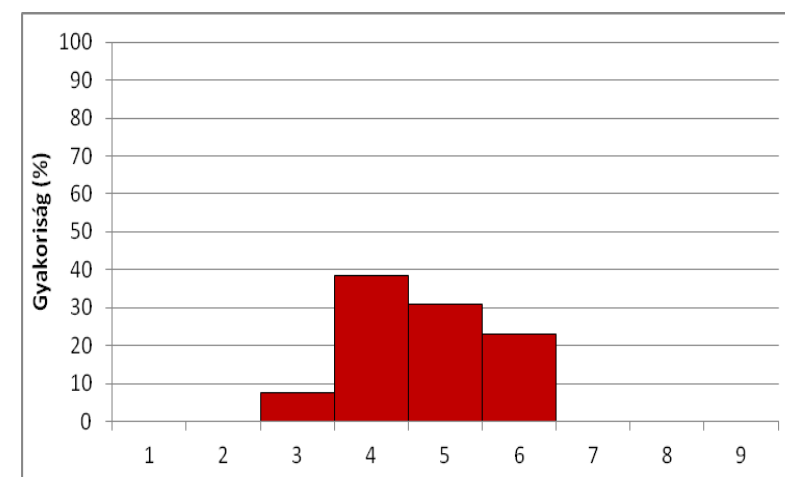

A

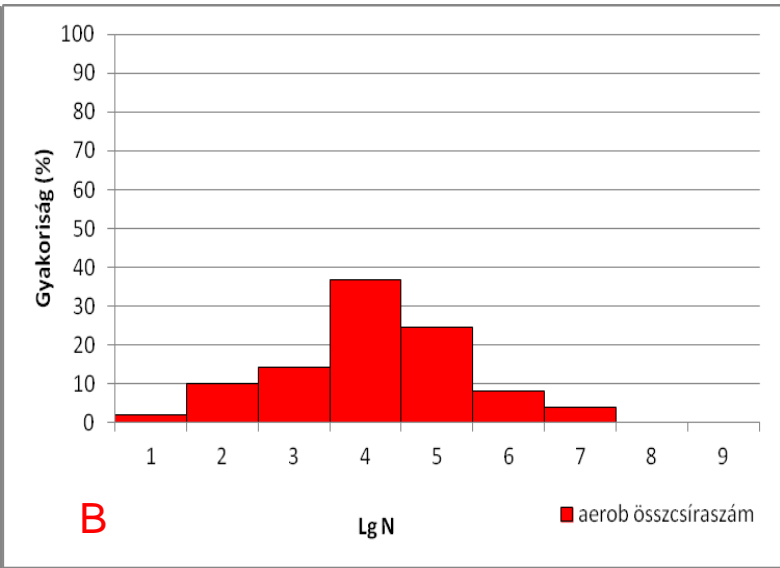

20.ábra: Ökológiai (A) és integrált (B) termesztésű meggy minták aerob összcsíraszám szennyezettségének gyakorisági eloszlása a vizsgált 3 évjárat mintáiban.
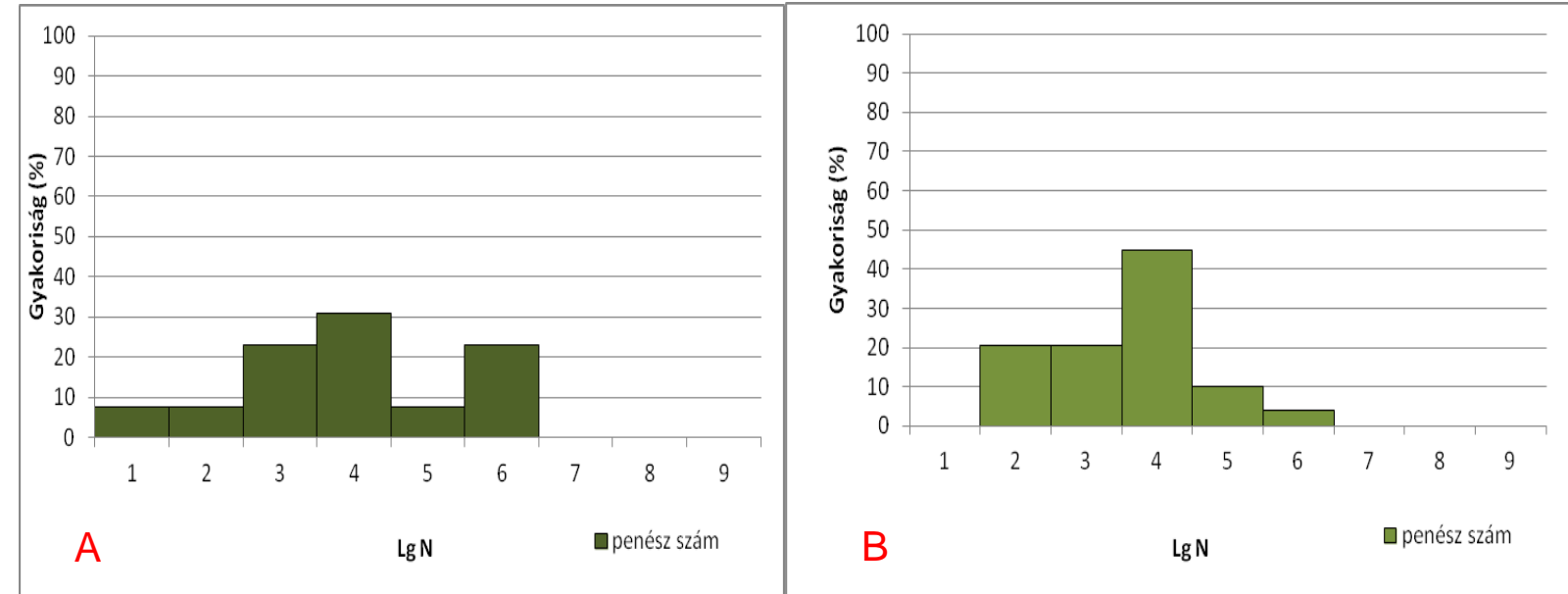

21.ábra: Ökológiai (A) és integrált (B) termesztésű meggy minták penészgomba szennyezettségének gyakorisági eloszlása a vizsgált 3 évjárat mintáiban.

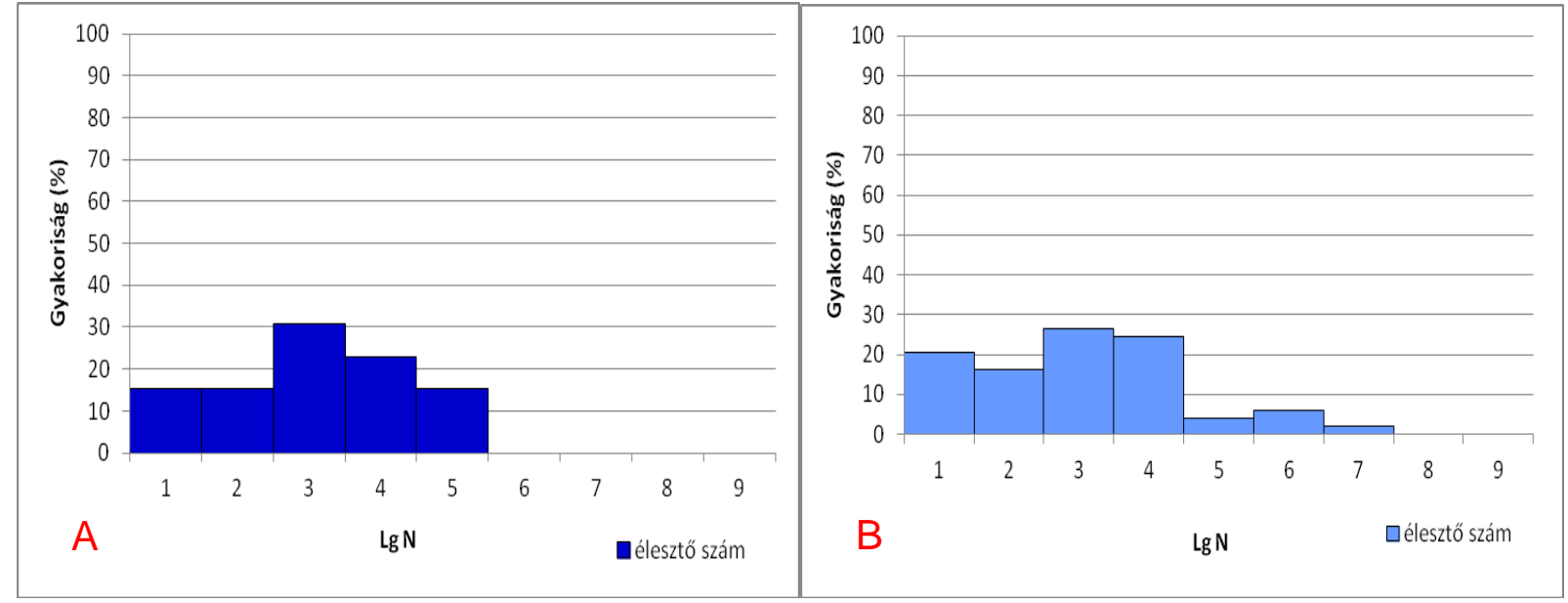

22.ábra: Ökológiai (A) és integrált (B) termesztésű meggy minták élesztőgomba szennyezettségének gyakorisági eloszlása a vizsgált 3 évjárat mintáiban. 
A mikrobiális szennyezettség mértéke a ökológiai és integrált párok esetében az egyes évjáratokban

Az ökológiai és integrált termesztésből származó minták összevetése (23-25. ábra) során az egyes évjáratok közötti különbség nagyobbnak bizonyult, mint a termesztési módból adódó különbség. A szárazabb 2008-as évben az 'Érdi bötermö' bio és a 'Kántorjánosi 3' bio fajtáknál 1,5 nagyságrenddel magasabb mikrobiális szennyezettség volt kimutatható, mint integrált párjaiknál. A 2009-es kedvező időjárás során a bio és integrált minták között nagyobb eltérés csak az 'Érdi bőtermő' fajtánál volt detektálható, mintegy kettő nagyságrenddel, mindhárom mikrobacsoport tekintetében. A 'Debreceni bőtermö' fajta bio és integrált termesztésű mintáinál, a 2010-es év kisebb különbségeit leszámítva, nem volt eltérés mikrobiális szennyezettséget tekintve a két termesztési mód között. A 2010-es év szélsőséges és esős időjárása kedvező volt, kis szennyezettség volt mérhető az egyes mintákon (a legmagasabb érték a bio 'Érdi bötermö' élesztő szennyezettsége 4,8 tke/ $\mathrm{cm}^{2}$ ).

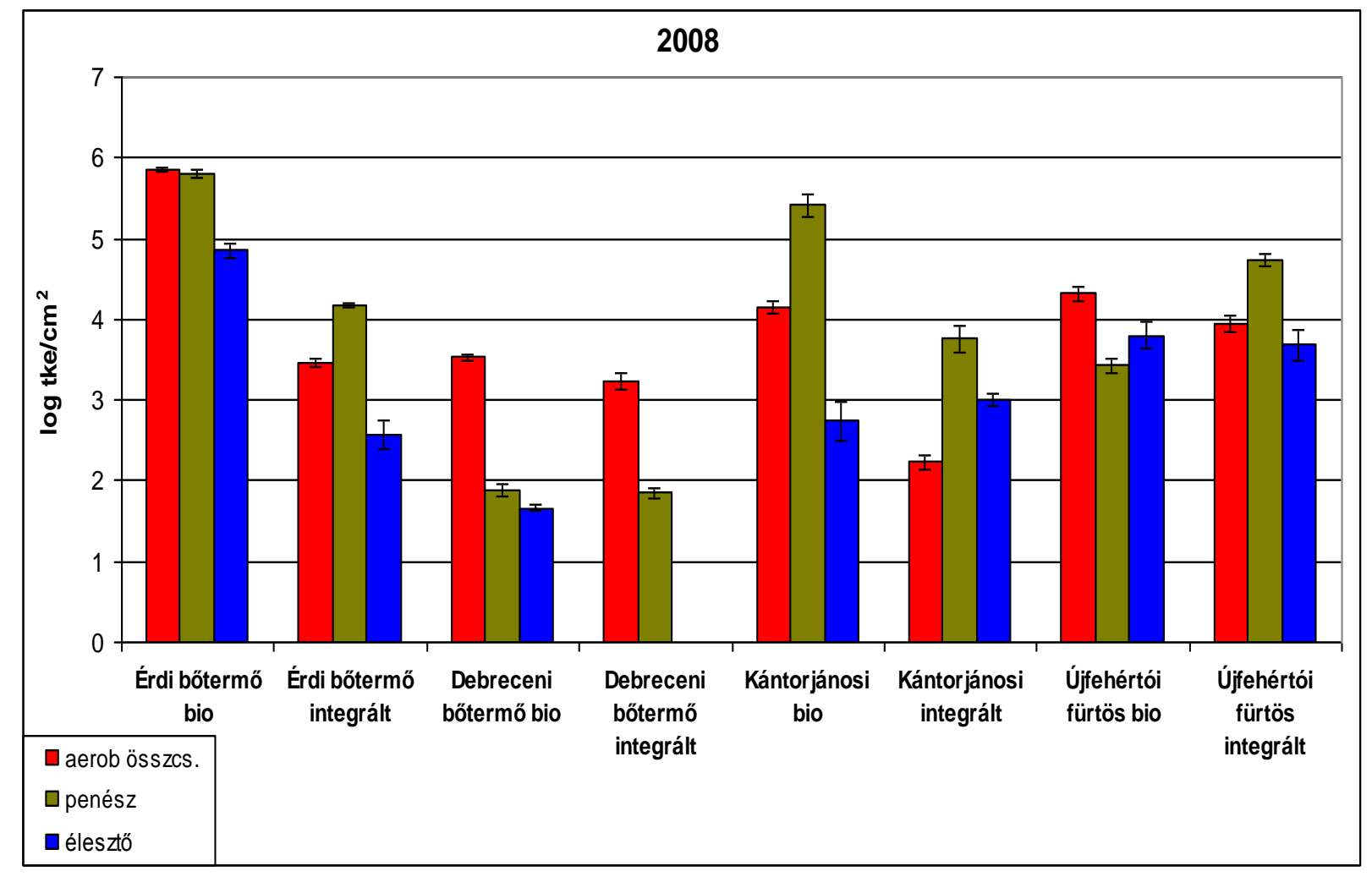

23. ábra: Bio és integrált meggypárok mikrobiológiai szennyezettsége 2008-ban. 


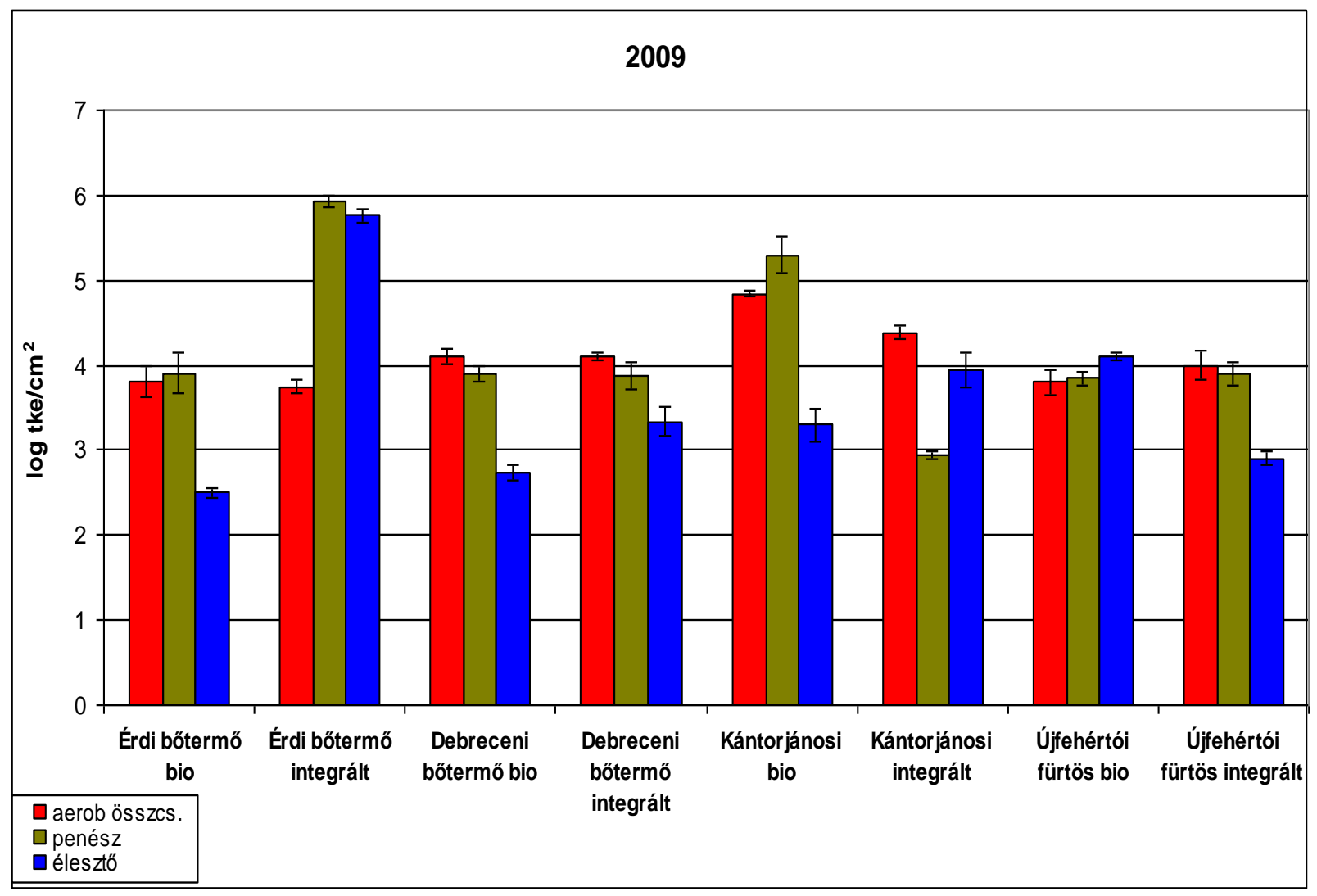

24. ábra: Bio és integrált meggypárok mikrobiológiai szennyezettsége 2009-ben.

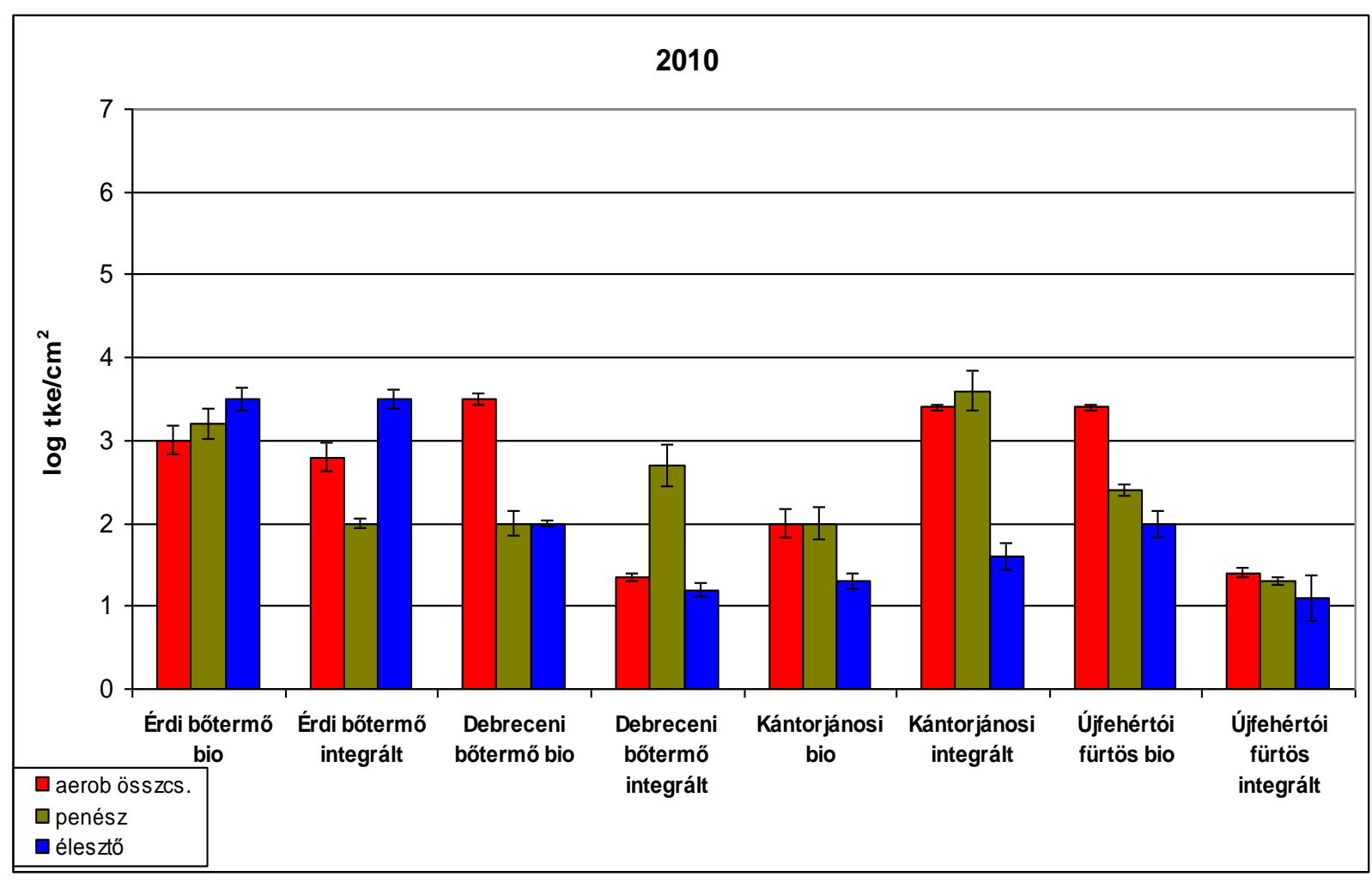

25. ábra: Bio és integrált meggypárok mikrobiológiai szennyezettsége 2010-ben. 
Mikrobiális szennyezettség mértéke az egyes fajták esetében a három évjáratban.

A 15 meggy fajta évjáratonkénti összehasonlításában a fajták közötti különbséget néztem, ezért itt csak az integrált termesztésü minták szerepelnek. Minden egyes évjáratra lebontva (26-2930. ábra) ábrázoltam a leginkább jellemző szennyezettségi profilt (aerob összes élőcsíraszám, penész-és élesztőgomba szám). Megfigyelhető a ' $V N$ ' meggyek viszonylag nagy aerob összes élőcsírás szennyezettsége mindhárom évjáratban. Az 'Oblacsinszka' meggynek kicsi a szennyezettsége mindhárom évjáratban $\mathrm{Az}$ élesztővel való szennyezettség alapvetően mindenhol egy nagyságrenddel kisebb, mint az aerob összes élőcsíraszám. Az egyes évjáratok közötti különbség jól megfigyelhető. A 2008-as évjáratban, csakúgy, mint a többiben az aerob összcsíraszám magas volt $\left(10^{5} \log \mathrm{tke} / \mathrm{cm}^{2}\right)$ a 'VN' meggyek és a 'Cigány' meggyek esetében. Ebben az évjáratban magas $\left(10^{4}-10^{5} \log\right.$ tke/ $\left.\mathrm{cm}^{2}\right)$ penész szennyezettség volt jellemző az 'Újfehértói fürtös', 'Kántorjánosi 3' és 'Érdi bőtermö' fajtáknál. Az utóbbiaknál viszonylag magas $\left(2,5-3,8 \times 10^{3} \log\right.$ tke/ $\left.\mathrm{cm}^{2}\right)$ élesztőszám volt detektálható. A 2008-ban az integrált termesztésű minták romlási folyamatainak (27. ábra) követése során $1000 \mathrm{~g}$ minta 6 hetes tárolása után a minták százalékos megoszlásában a penészes romlás a második arányaiban. A penészes romlási adatok százalékos megoszlása összhangban vannak a 20. ábrán bemutatott penész szennyezettséggel. Az 'Újfehértói fürtös' fajtánál a minták 25,9\% mutatta a penészes romlást, a ''Kántorjánosi 3' fajtánál 13,2\%, a 'Debreceni bötermö' fajtánál pedig 11,2\%. Ugyanakkor elég magas volt az ép szemek aránya (27. ábra), mind az öt fajta esetén. A 2009-es évben mindhárom szennyező esetében nagyobb értékeket tudtam kimutatni, míg 2010-ben a szélsőséges és esős időjárása kis mikrobaszámot eredményezett. Mikrobiális szennyezettség alapján a három év során gyüjtött adatokat felhasználva a fajtákat öt csoportba osztottam hierarchikus klaszteranalízis (30. ábra) segítségével. Az 'Oblacsinszka' és a 'Pipacs' meggy szennyezettsége a legalacsonyabb (3,2,1 log tke/ $\left.\mathrm{cm}^{2}\right)$. A kékkel jelölt csoportnál az aerob összcsíraszám nagy (4-5 log tke/cm2), viszont a penész-és élesztőgomba szennyezettség közepes vagy kis-mértékü (1-2 log tke/ $\left.\mathrm{cm}^{2}\right)$. A zölddel jelölt csoportban közepes szennyezettség jellemző mindhárom mikrobacsoportra vonatkozóan $\left(3 \log\right.$ tke $\left./ \mathrm{cm}^{2}\right)$. 


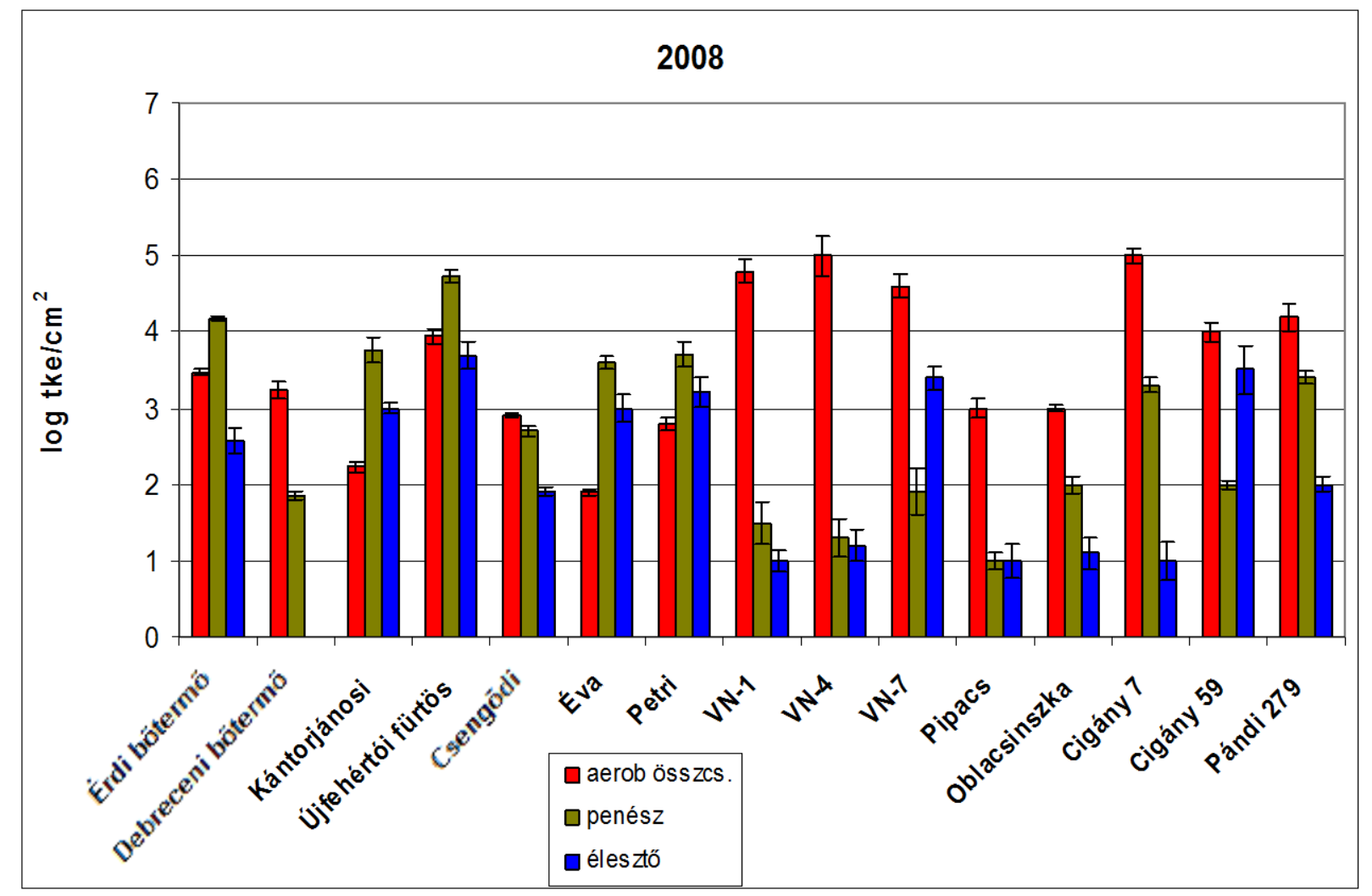

26. ábra: Integrált termesztésủ meggyfajták mikrobiológiai szennyezettsége 2008-ban.

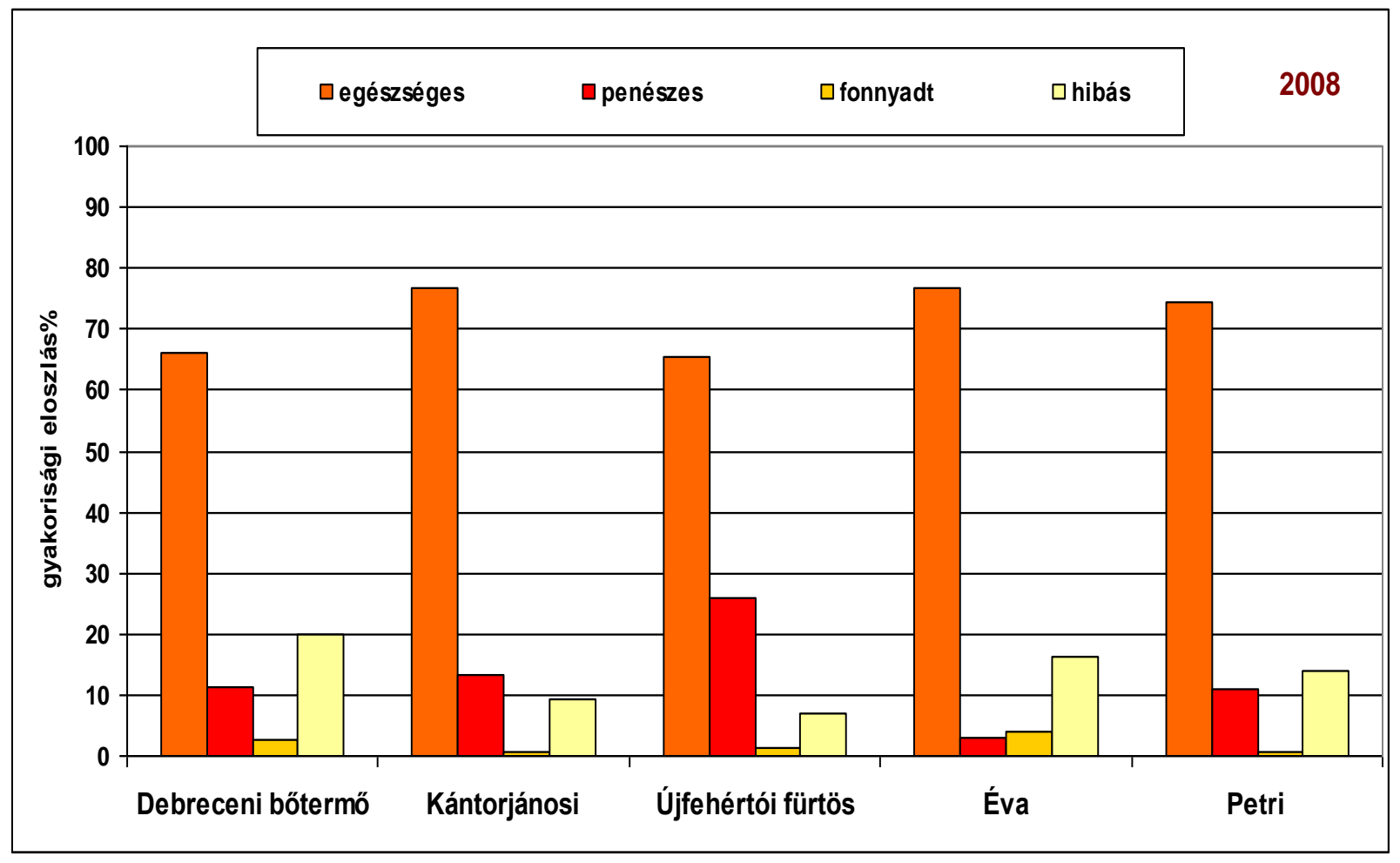

27. ábra: Integrált termesztésű meggyfajták romlási adatainak gyakorisági eloszlása 2008-ban. 


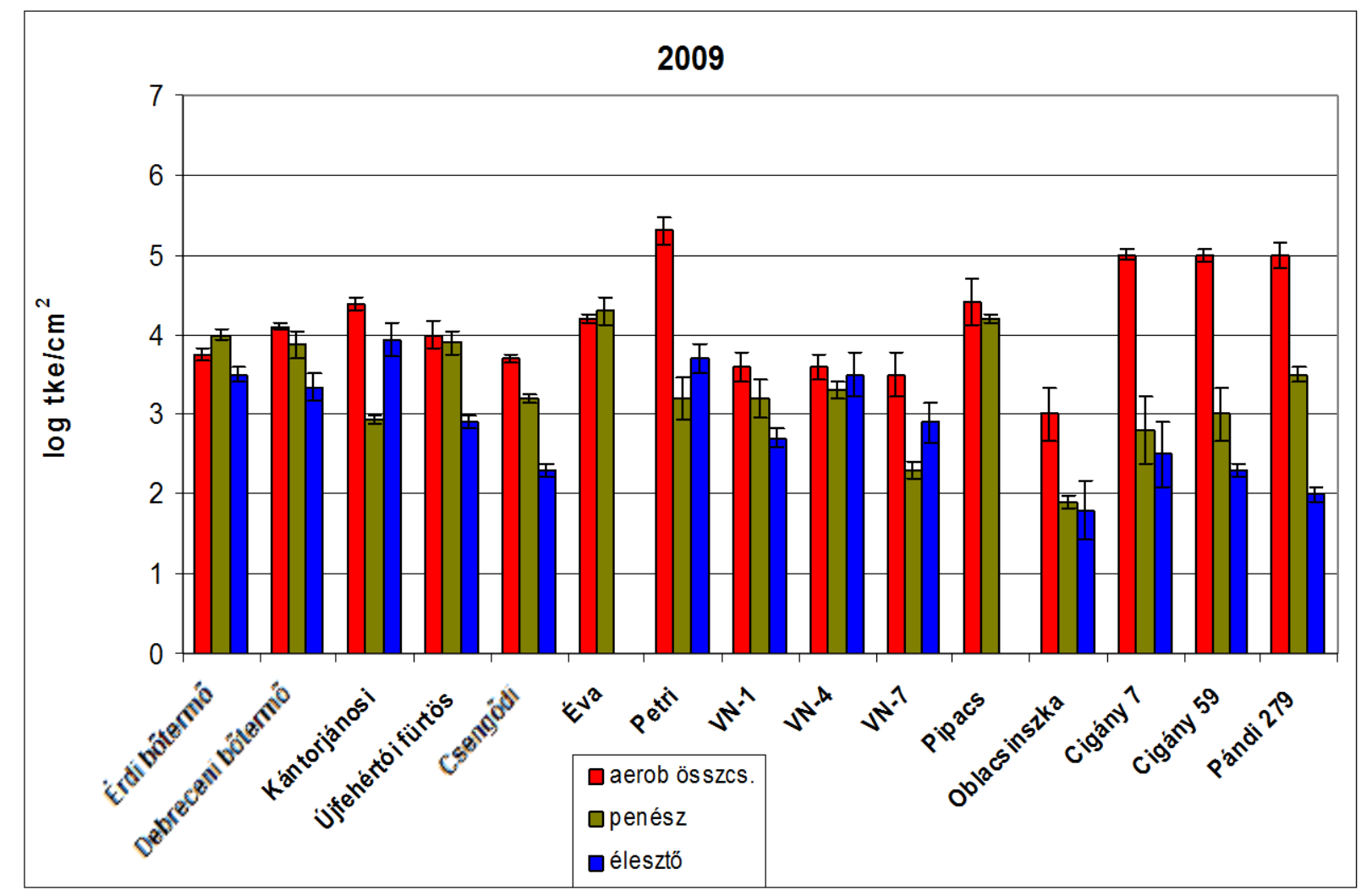

28. ábra: Integrált termesztésủ meggyfajták mikrobiológiai szennyezettsége 2009-ben.

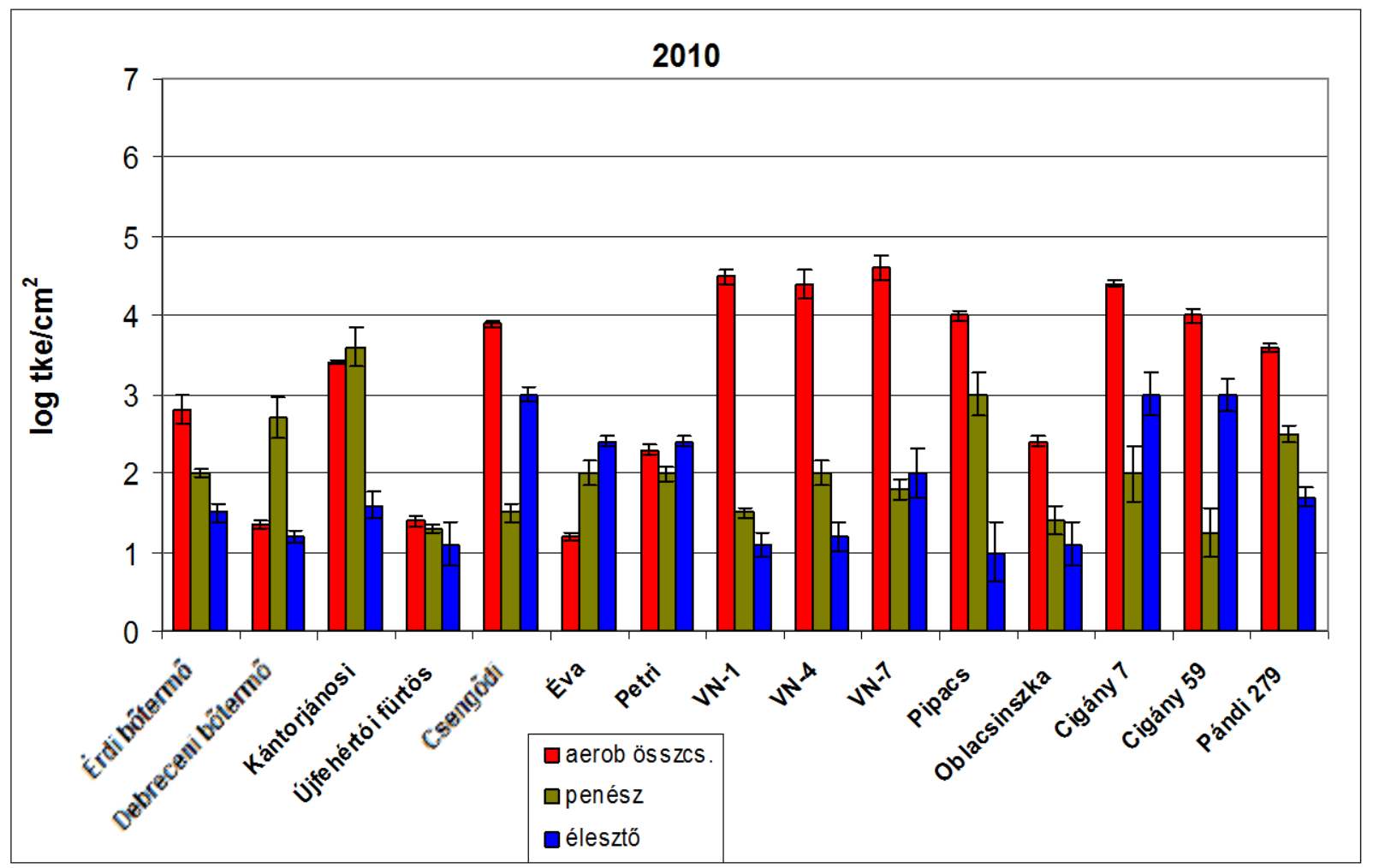

29. ábra: Integrált termesztésű meggyfajták mikrobiológiai szennyezettsége 2010-ben. 


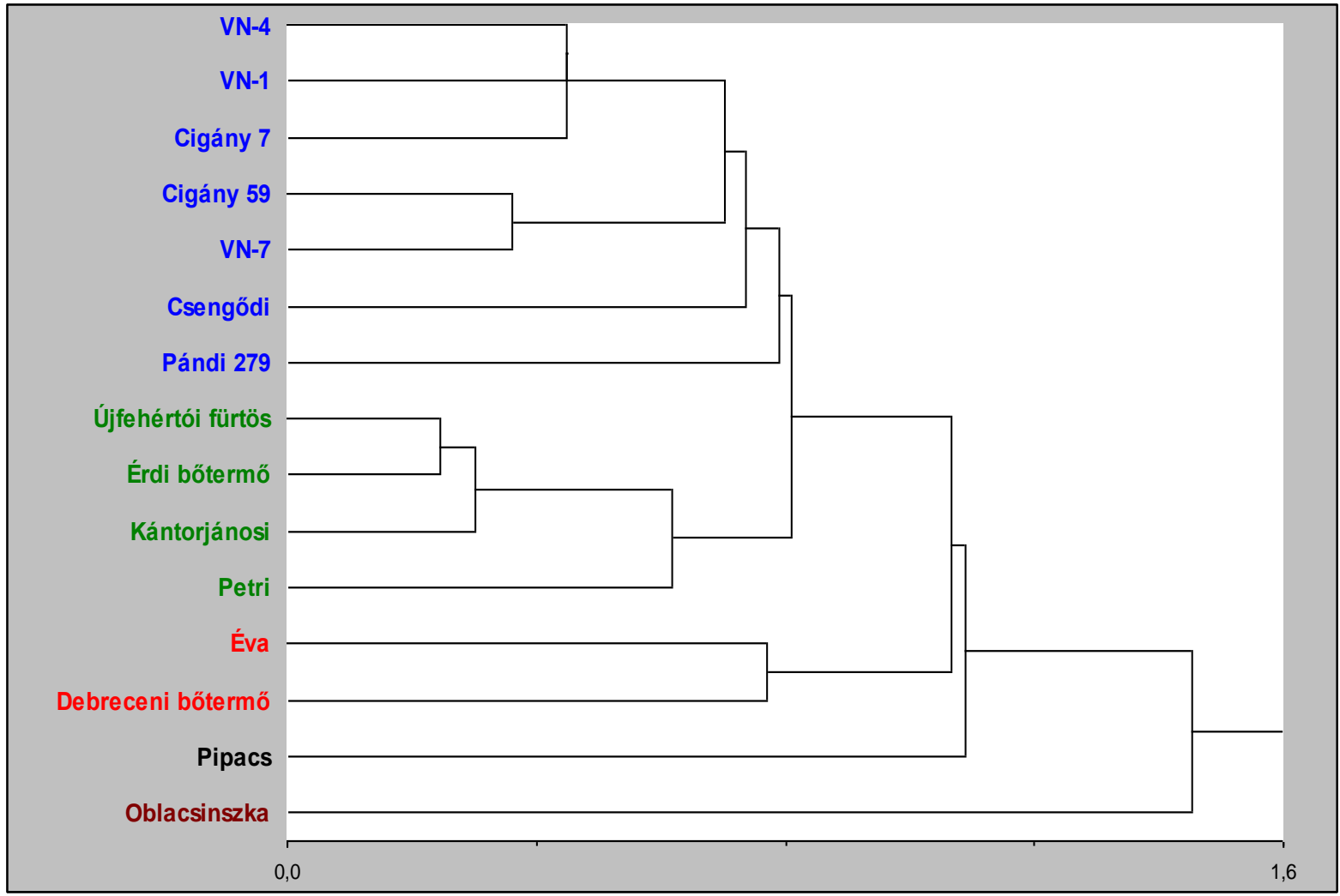

30. ábra: Integrált termesztésű meggyfajták csoportosítása három éves átlagos mikrobiológiai szennyezettség alapján hierarchikus klaszteranalízissel.

\subsubsection{Cseresznye mikrobiológiai vizsgálata}

A három éves (2008-2009-2010) átfogó vizsgálatok alatt három fajta cseresznye vizsgálatára került sor. A minták közül egyben sem volt kimutatható Salmonella spp., Listeria spp. és Enterobacter sakazakii baktérium. A kóliform baktériumok szórványosan fordultak elő a gyümölcs felületén a meghatározási limit környékén $\left(10 \mathrm{tke} / \mathrm{cm}^{2}\right)$ volt. E. coli és Pseudomonas aeruginosa jelenléte nem volt kimutatható a cseresznye minták felületén. Az egyes cseresznye minták felületére jellemző mezofil aerob összcsíraszámot és a penész- és élesztőgomba számot meghatározta az évjárat (31. ábra). Csak integrált termesztésü mintákat tudtam vizsgálni, ezért a termesztési módok összehasonlítására nem volt lehetőség. A cseresznyeminták közül a 'Firm Red' volt a legkevésbé szennyezett (átlag $10^{2}$ tke $/ \mathrm{cm}^{2}$ ) (31. ábra). 


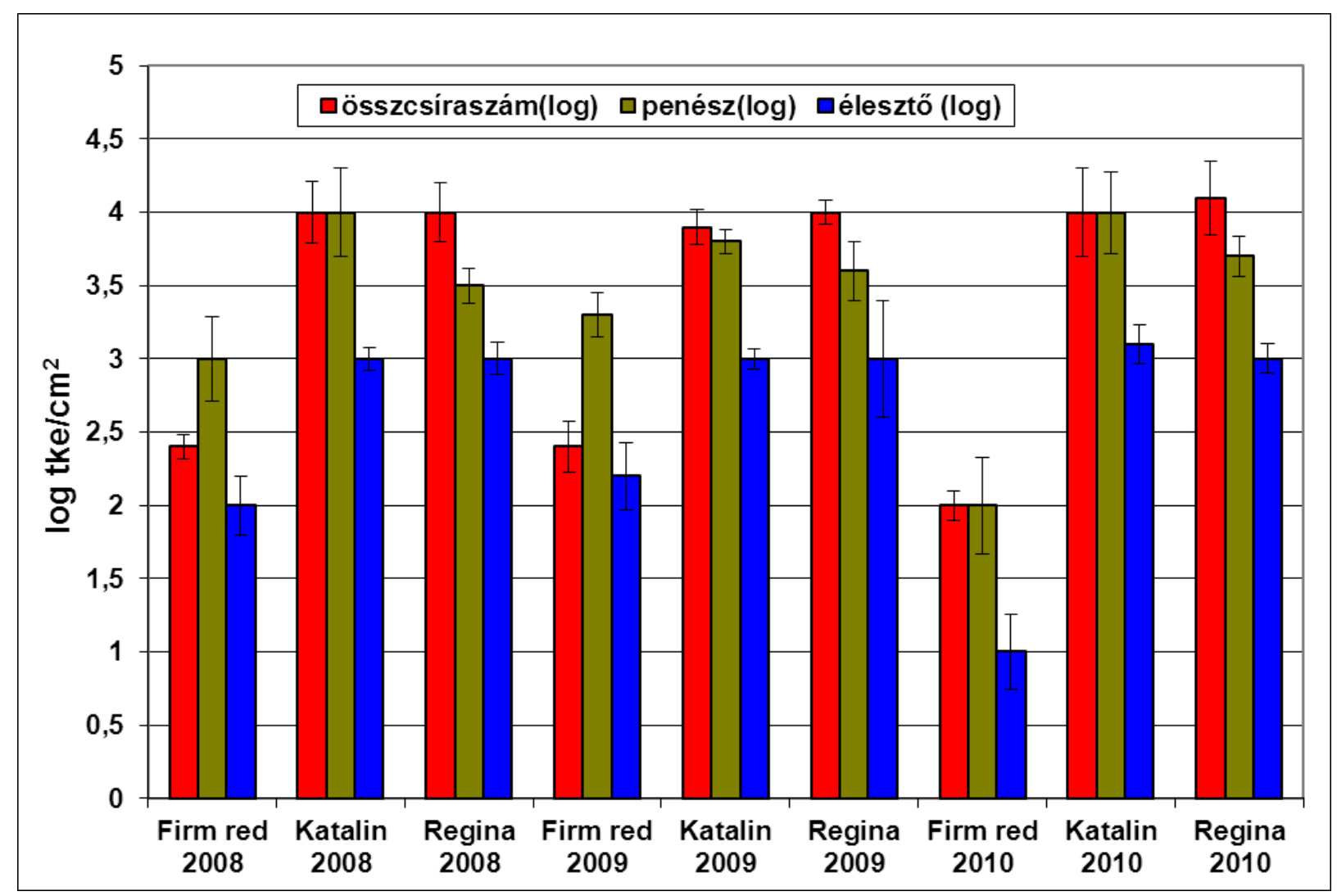

31. ábra: Cseresznye fajták évjáratonkénti mikrobiológiai szennyezettsége

\subsubsection{Alma mikrobiológia vizsgálata}

A három éves (2008-2009-2010) átfogó vizsgálatok alatt 33 fajta alma vizsgálatára került sor, melyekből 8 fajta volt, mely mindhárom évjáratban rendelkezésre állt. Ebből 5 fajta ('Gala', 'Prima', 'Remo', 'Topáz', 'Idared') esetében három évjáratból ökológiai és integrált termesztésü mintát egyaránt tudtunk vizsgálni. Egy esetben sem volt kimutatható Salmonella spp. , Listeria spp. és Enterobacter sakazakii baktérium. A kóliform baktériumok szórványosan fordultak elö a gyümölcs felületén, a meghatározási limit körül $\left(10 \mathrm{tke} / \mathrm{cm}^{2}\right)$ volt. E. coli jelenléte nem volt kimutatható az almák felületén. Pseudomonas aeruginosa a 2009-es évjáratban a bio-termesztésü Idared és Prima fajtán fordult elö. Az egyes alma minták felületére jellemző mezofil aerob összes élöcsíraszámot, penészgomba számot és élesztőgomba számot meghatározta az évjárat (32.-34. ábra). Az ökológiai és integrált termesztés hatásának vizsgálatakor megállapítható volt, hogy az ökológiai termesztés esetén nagyobb a minták aerob összes élőcsíraszáma és penészgomba száma, de nem szignifikánsan $(\mathrm{p}<0,05)$. Az élesztőgomba szám ebben az összehasonlításban független volt a termesztési módtól. Az Idared fajtának mind három évjáratban nagy volt az élesztőgomba szennyezettsége. 


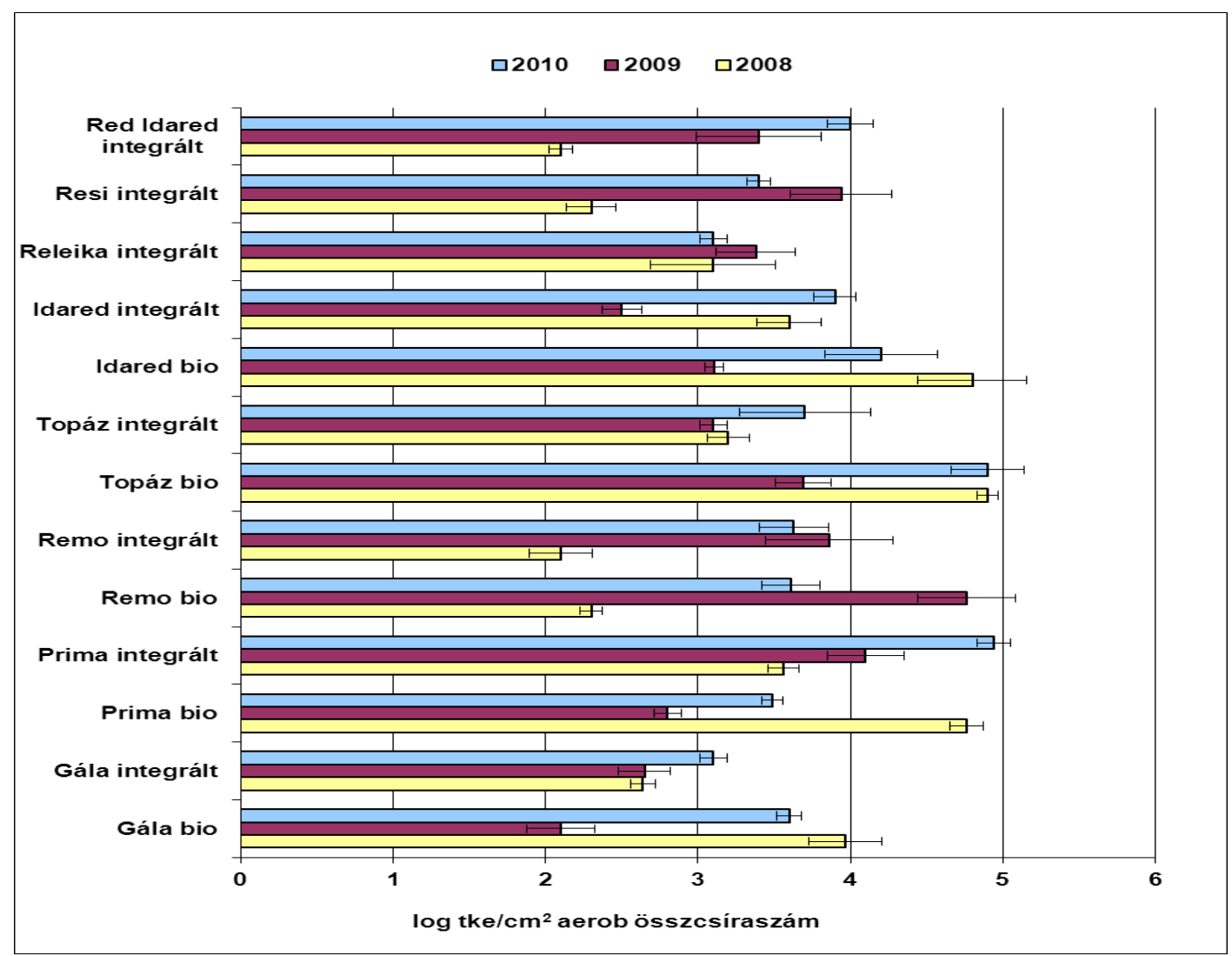

32. ábra: Almafajták aerob összes élőcsíraszáma a három évjáratban

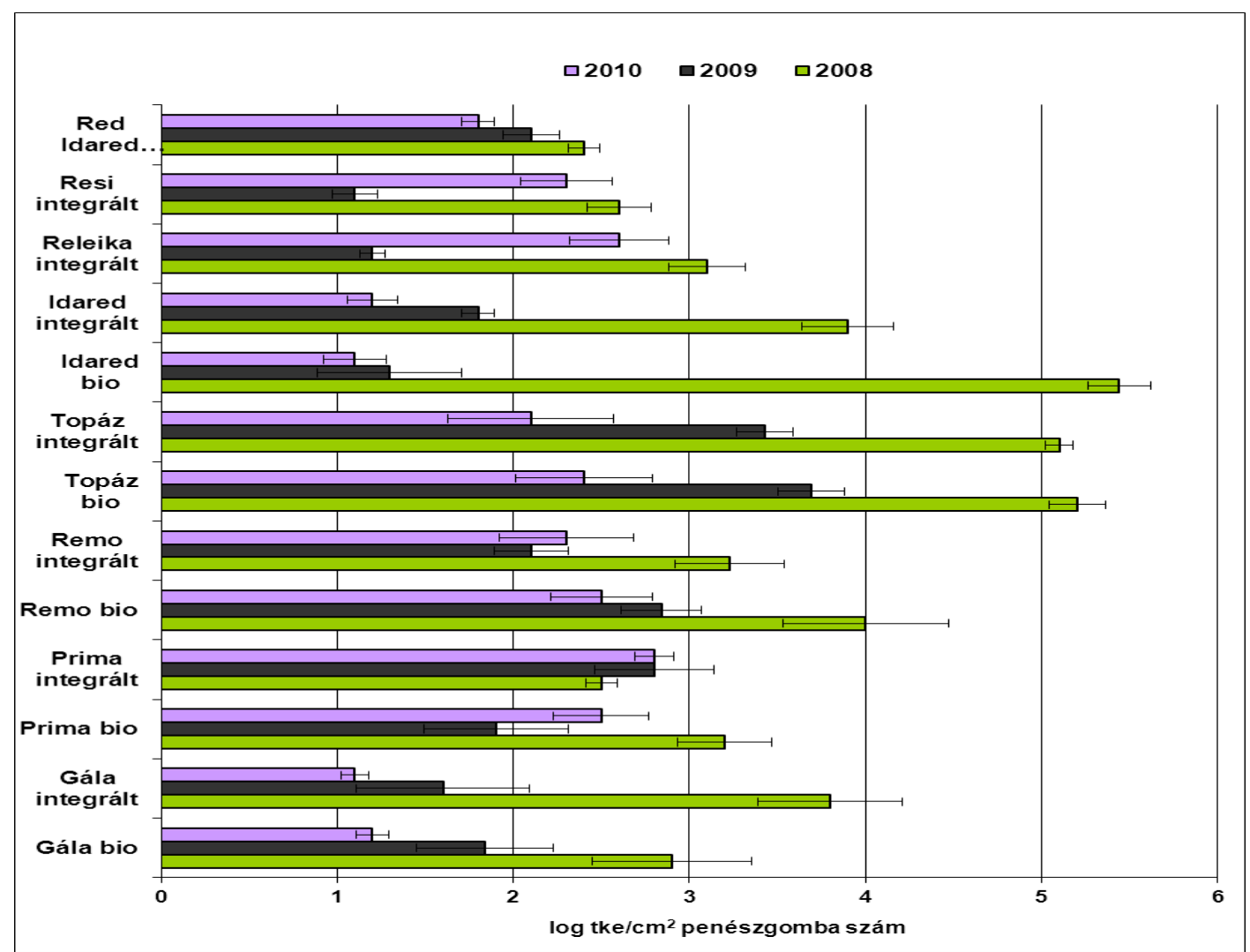

33. ábra: Almafajták penész szennyezettsége a három évjáratban 


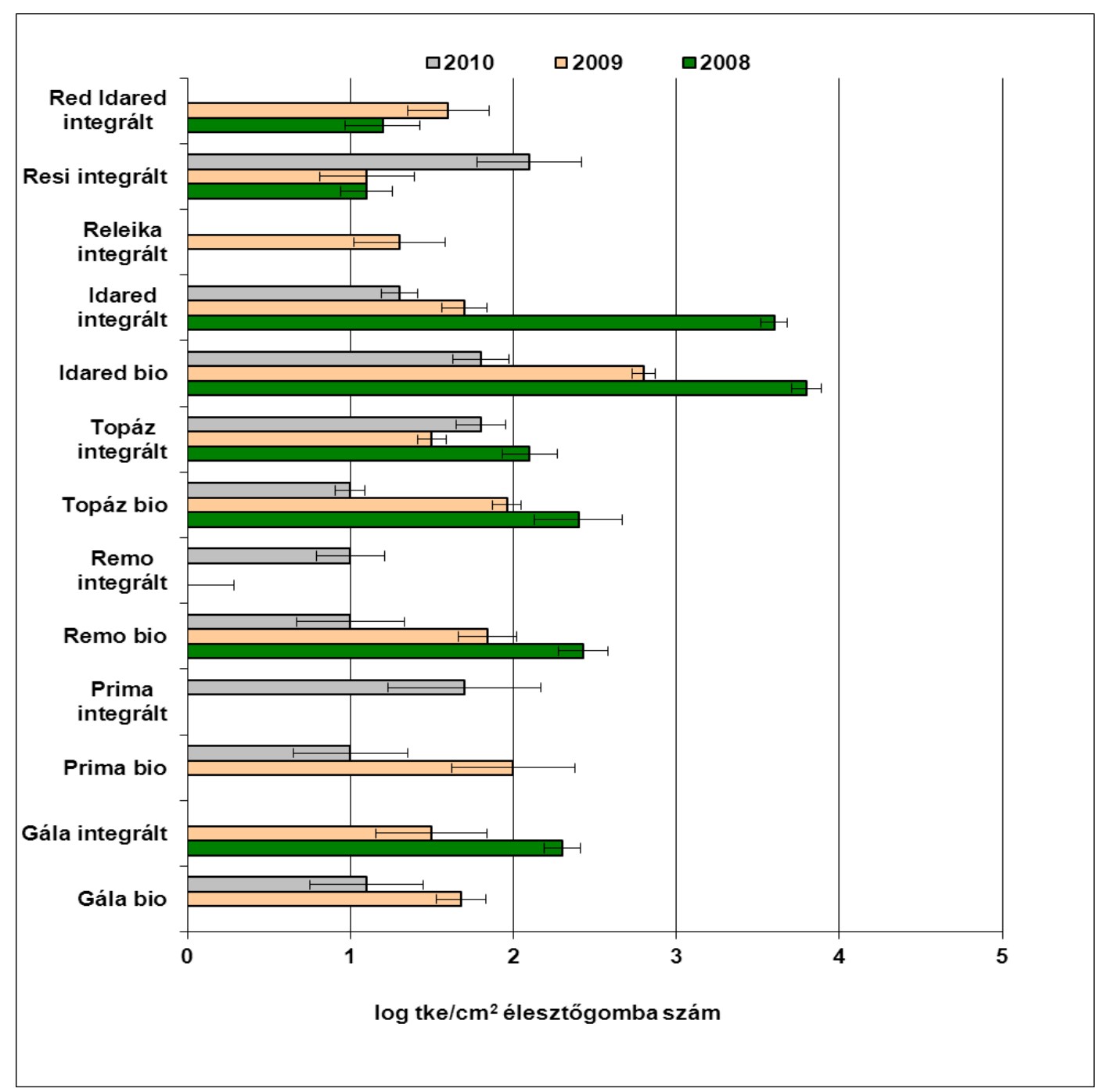

34. ábra: : Almafajták élesztő szennyezettsége a három évjáratban

A mikrobiológiai szennyezettség gyakorisági eloszlása

A termesztési mód hatásának további vizsgálatához megnéztem az egyes mikrobiológiai szennyezők gyakoriságát a két termesztési módnál (28.-30. ábra).

Az ökológiai termesztésben, ha nem is szignifikánsan $(\mathrm{p}<0,05)$, de gyakoribb volt a nagyobb szennyezettség, mint az integrált termesztésnél. Ez jól látszik mindhárom mikrobacsoport esetében (35-37. ábra). Fontos, hogy az évjárat, vagyis az időjárás hatása szintén nem elhanyagolható tényező. 

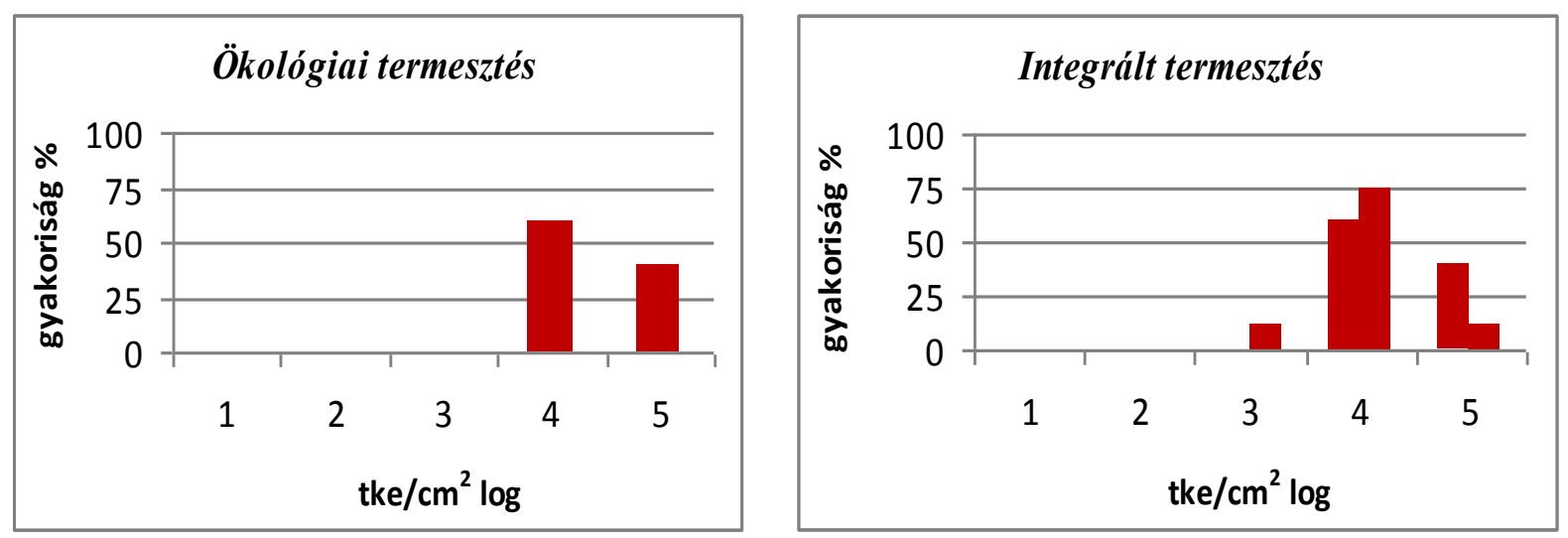

35. ábra: Almaminták átlagos - három évjáratra vonatkozó - összes csíraszáma integrált és ökológiai termesztésben
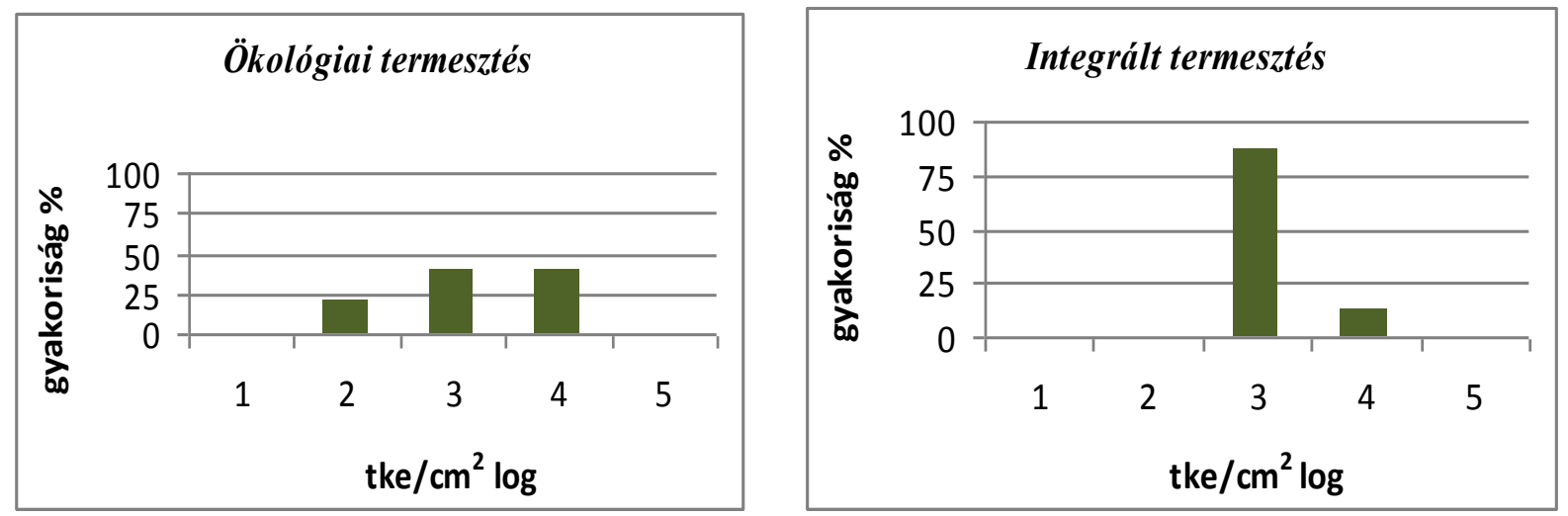

36. ábra: Almaminták átlagos - három évjáratra vonatkozó - penész szennyezettsége integrált és ökológiai termesztésben
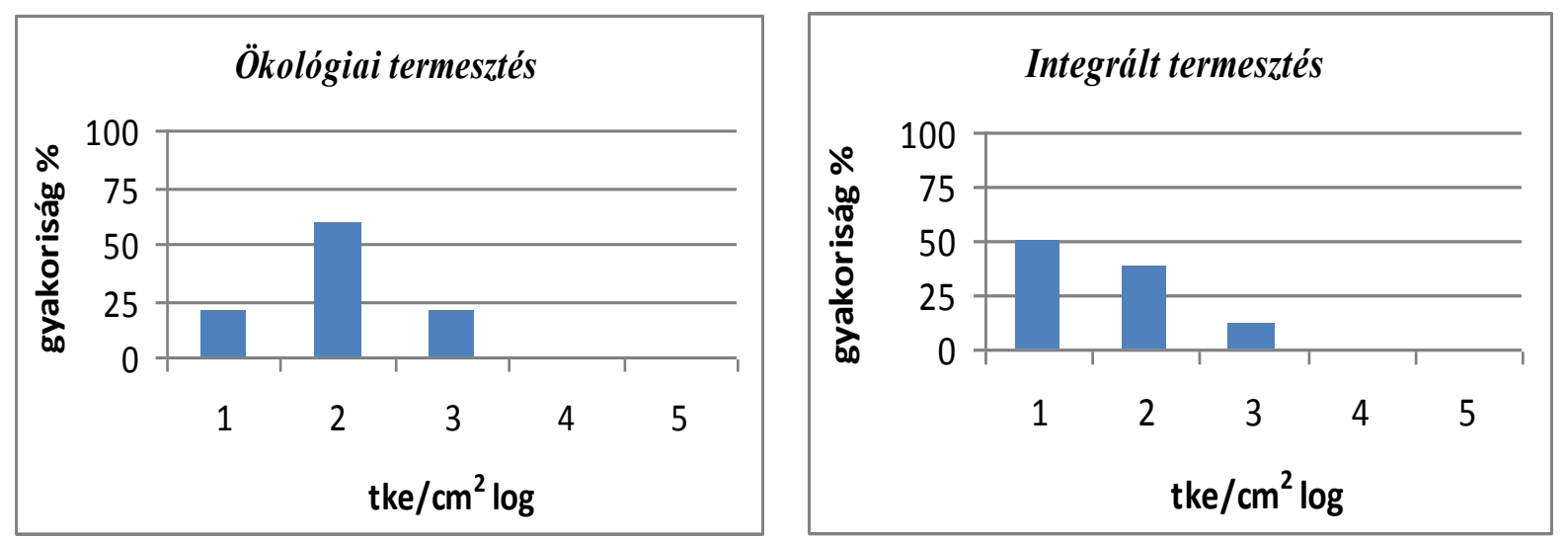

37. ábra: Almaminták átlagos - három évjáratra vonatkozó - élesztő szennyezettsége integrált és ökológiai termesztésben 


\subsubsection{Körte mikrobiológiai vizsgálata}

Körte minták vizsgálata a 2008-2009-es évjáratokból történt integrált termesztésű mintákból. A mikrobiológiai szennyezettsége mindkét évjáratban viszonylag alacsony volt, kivéve a 2008-as 'Conference' fajta élesztő- és penészgomba szennyezettségét (38. ábra). A minták közül egyben sem volt kimutatható Salmonella spp., Listeria spp., kóliform baktériumok, E. coli , Pseudomonas aeruginosa és E. sakazakii baktérium. Csak integrált termesztésű mintákat tudtam vizsgálni, ezért a termesztési módok összehasonlítására nem volt lehetőség. Itt is megfigyelhető az évjárat hatása, a 2009-es minták bizonyultak szennyezettebbeknek.

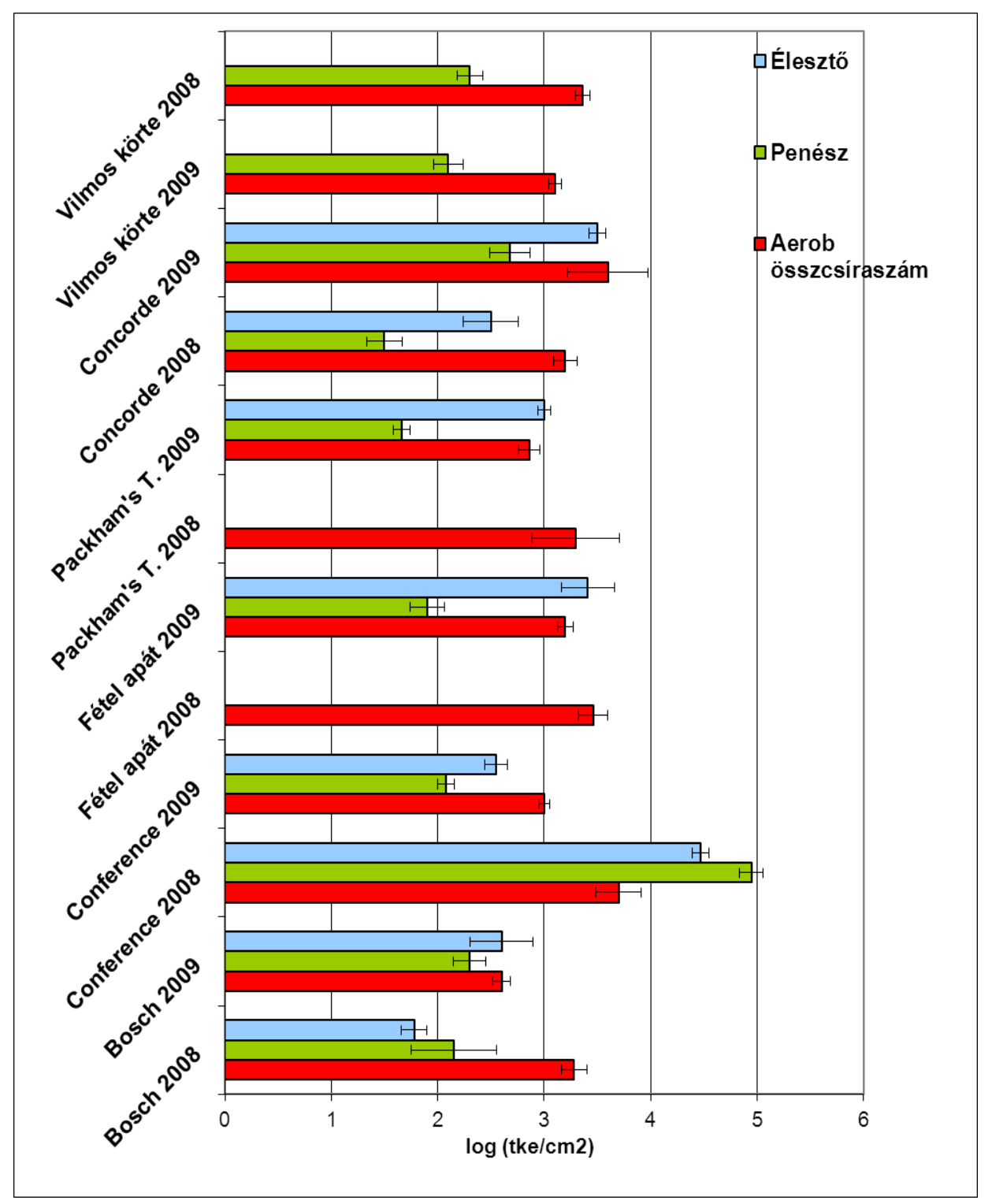

38.ábra: Körték mikrobiális szennyezettsége 


\subsubsection{Brix-fok és savtartalom meghatározás}

A vizsgálat egyik célja annak megállapítása volt, hogy az egyes gyümölcsök esetében a fajta, a termesztési mód (ahol releváns) vagy az évjárat vagy esetleg a felsorolt tényezők mely kombinációi befolyásolják a szárazanyag- és savtartalmat. A szárazanyag-tartalomnak fontos szerepe van a gyümölcs érettségének megállapításánál illetve az ipari feldolgozás esetében is (főként az almánál). Valamint, az ízérzet kialakításában is szerepet játszik, ezen keresztül, pedig a fogyasztói megítélésben. A Brix/sav hányados meghatározásával az egyes fajták ízérzetét kategorizáltam. A vizsgált gyümölcsök cukor-sav arányát a refrakció értékekből és a titráható savtartalomból számítottam ki a 2008-2009-2010-es évjáratban.

\subsubsection{Meggy Brix fok és savtartalom}

Az egyes meggyfajták Brix fokának mérése után az eredményeket különféleképpen csoportosítottam (39-41. ábra) választ keresve a különbségekre. Négy meggyfajtánál tudtam vizsgálni a termesztési mód hatásából származó különbségeket. A Brix-fok mérésekor termesztési módból származó szignifikáns $(\mathrm{p}<0,05)$ különbséget nem találtam. Ha évjáratok szerint vizsgáljuk, az egyes évjáratok között találunk eltéréseket. A Brix fok a 2008-as és 2010es évben magasabb, mint a 2009-ben azonos fajtákat alapul véve. Szabó és munkatársai (2010) szerint azokban az években, amikor magasabb a hőingadozás a nappal és éjszaka között, megnő a meggy szárazanyag-tartalma, viszont túlzottan nagy hőmérséklet különbség esetén ez az összefüggés nem áll fenn. A 2010-es évben a virágzás idején rendkívül szélsőséges időjárás volt, ezért kevés volt az átlaghoz képest a termés. 2010-ben a meggy későbbi fejlődési fázisaiban is szélsőségesebb volt az időjárás, mint az azt megelőző két évben. A 2009-es évben Kállay és munkatársai (2010) által mért érett, integrált termesztésű 'Érdi bőtermö' (19,5\% és 1,26\%) és 'Kántorjánosi 3' (15\% és 1,64\%) meggyek Brix foka és savtartalma hasonlóképpen alakult ('Érdi bötermő': 16,8\% és 1,1\%; 'Kántorjánosi 3': 17,4 és 1,3\%) az általunk mért mintákban is. Az eltérések ellenére a különbség nem szignifikáns $(\mathrm{p}<0,05)$ az évjáratot tekintve. Külön néztem fajtánként a három év átlagából számított Brix-fokot. Az egyes fajták évenkénti eredményeit összehasonlítva (41. ábra) elmondható, hogy a fajta hatása dominál a szárazanyagtartalom értékben a termesztési módhoz és évjárat hatásához képest. 


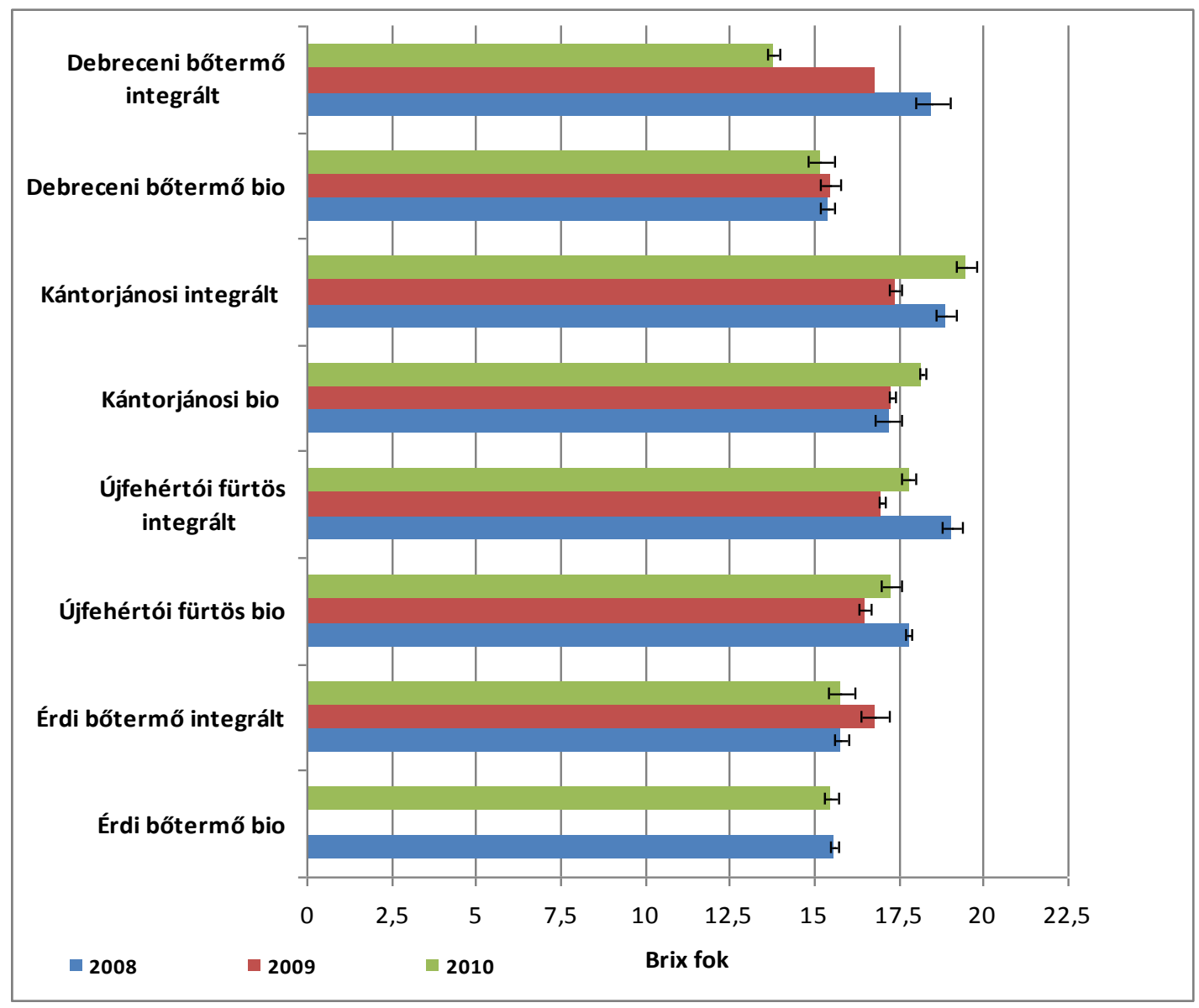

39. ábra: Négy meggyfajta szárazanyag tartalma a kétféle termesztési módnál

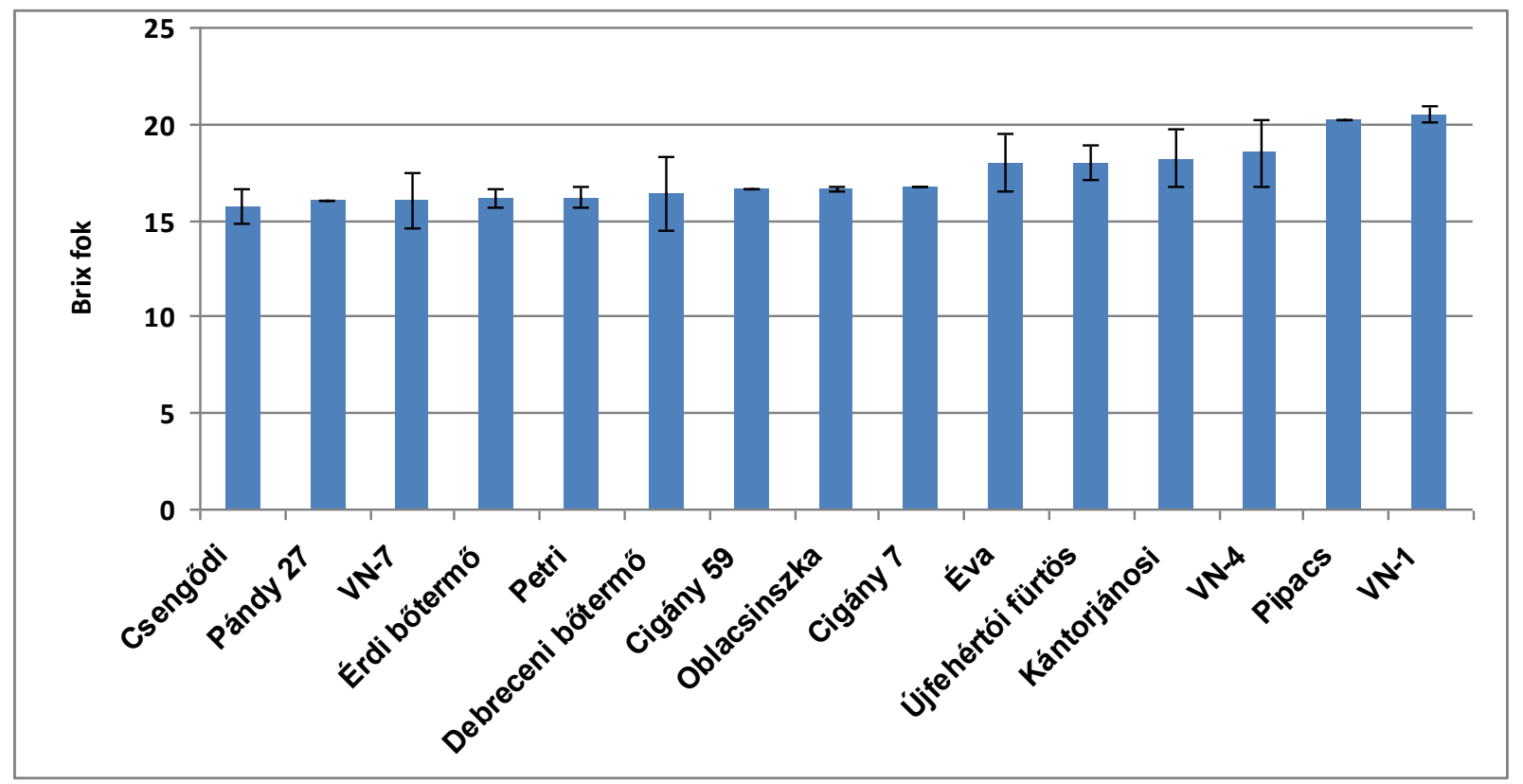

40. ábra: Integrált termesztésü meggyfajták Brix foka fajtánként 


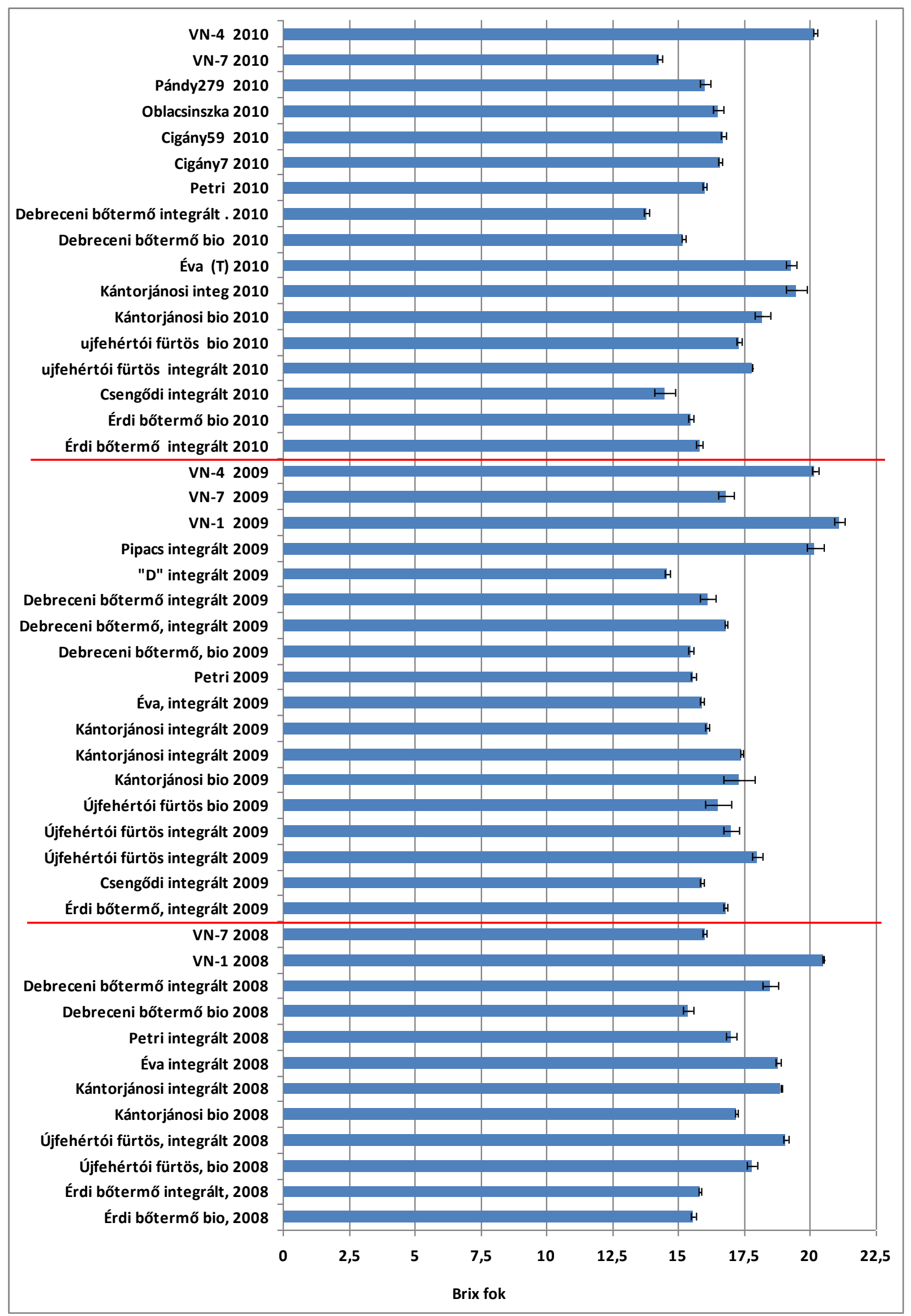

41. ábra: Meggyek brix foka az egyes évjáratok szerint 
A savtartalom vizsgálatakor szintén többféle összehasonlításban vizsgáltuk az eredményeket (35.-37. ábra)

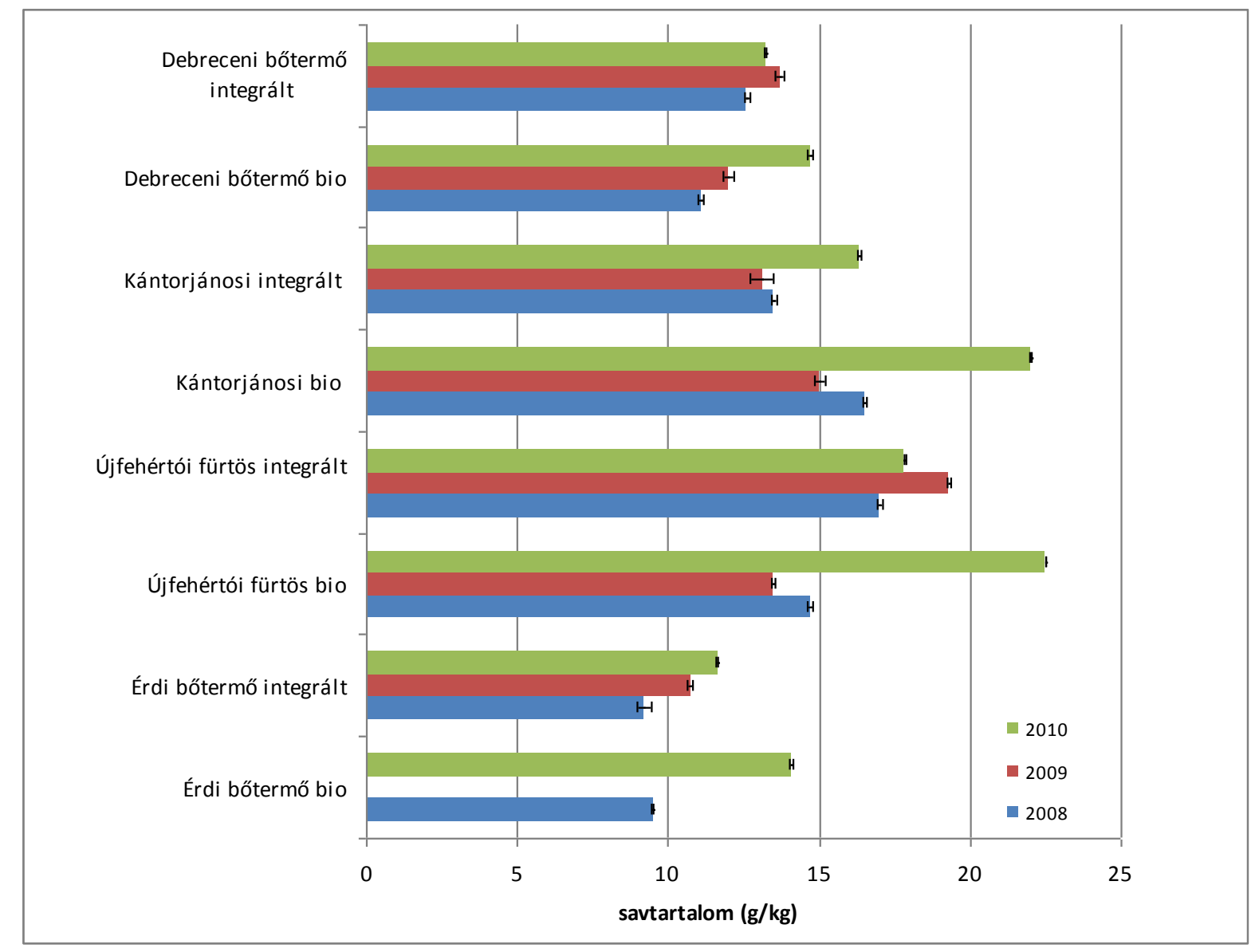

42. ábra: Négy meggyfajta sav tartalma a kétféle termesztési módnál

Habár a savtartalmat tekintve az eredmények alapján a bio termesztési módnál magasabb a savtartalom az egyes fajták esetében, a különbség nem szignifikáns ( $\mathrm{p}<0,05)$ (42. ábra). A savtartalom évenkénti hatása az adott év időjárási viszonyaihoz képest változik, de az egyes fajták évjáratonkénti eredményei egymástól szignifikánsan $(\mathrm{p}<0,05)$ nem különböznek (43. ábra).

A fajtánkénti átlagos savtartalom alakulását tekintve (44. ábra) a fajta hatása dominál a termesztési módhoz és évjárat hatásához képest. Legmagasabb a savtartalma az 'Oblacsinszka', 'Pipacs' és 'Cigány' meggyeknek. Szabó és munkatársai (2010) Újfehértón vizsgált 10 meggyfajtánál megállapították, hogy a csapadék mennyisége jelentős hatással van a savtartalom alakulására. Nagyobb csapadék mennyiség esetén a gyümölcs savtartalma alacsonyabb, míg 
száraz években nagyobb savtartalom jellemző. Megállapították, hogy magasabb hőmérsékletü években az összsavtartalom magasabb.

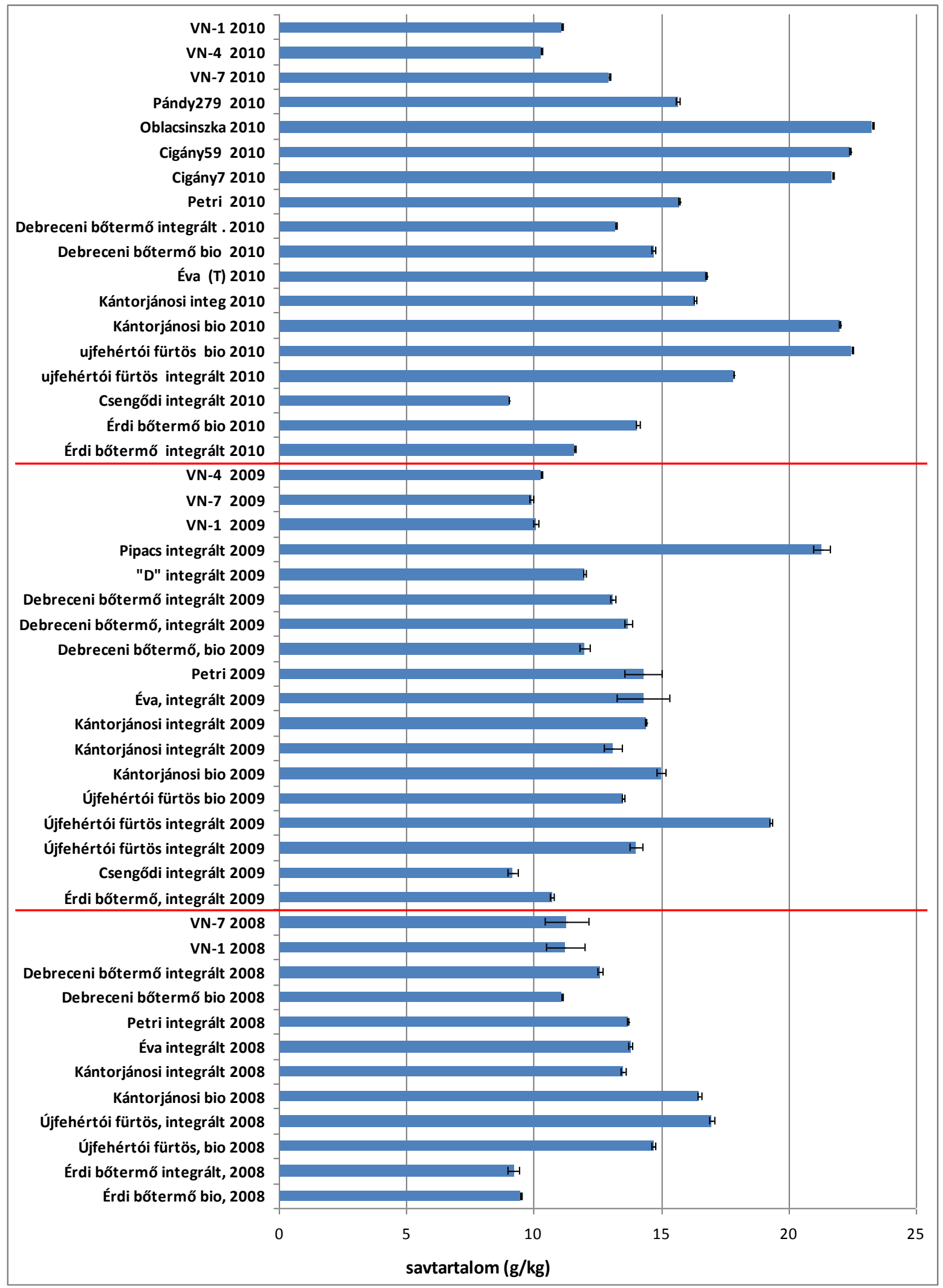




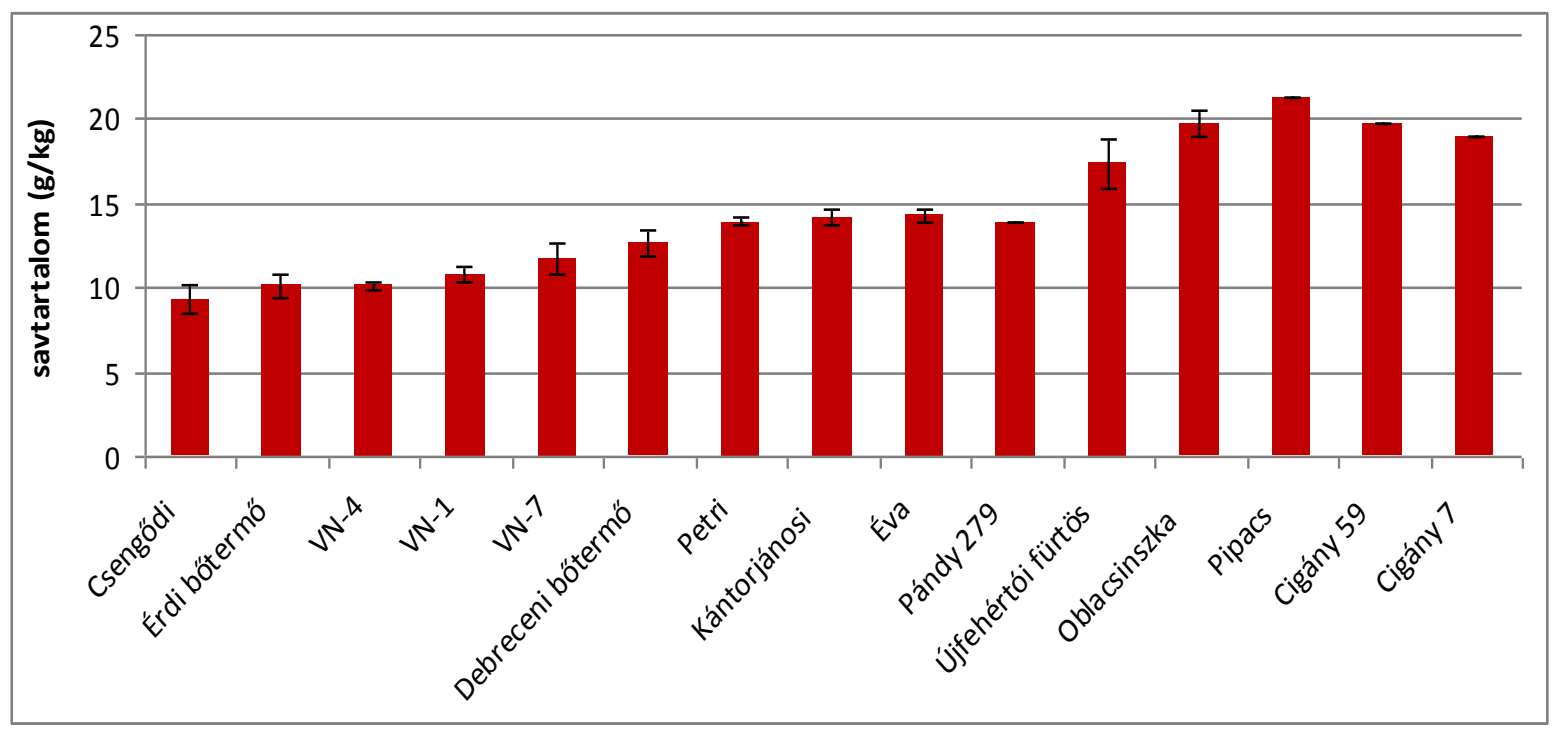

\section{4. ábra: Integrált termesztésű meggy fajták savtartalma fajtánként}

\section{MEGGY BRIX/SAV ARÁNYA}

Összesen 15 fajta meggynél vizsgáltuk a Brix/sav arány alakulását az átlagértékekből (45. ábra) számolva. Termesztési módot itt nem vettük figyelembe, mivel nincs szignifikáns $(\mathrm{p}<0,05)$ hatása a Brix fokra és savtartalomra az eredmények alapján. A kettő hányadosa befolyásolja az ízérzetet (9/a és 9/b. táblázat), melynek alapján négyféle csoportra osztottam a vizsgált fajtákat. Ez alapján meghatározott felhasználási csoportokat lehet megkülönböztetni az egyes fajták között. A 'Csengödi' meggy sav-és szárazanyag-tartalma a cseresznyére hasonlít. A 'VN-1' és 'VN-4' meggyeknél mindkét paraméter egyaránt elég magas, ezért a magas szárazanyag tartalom és az alacsony savtartalom édeskés ízt eredményez. A 'Pipacs' rendkívül magas titrálható sav-és szárazanyag tartalomú, azonban az íze miatt friss fogyasztásra alkalmatlan. Az 'Oblacsinszka' meggy kis mérete és savanykás íze miatt cukrászati felhasználásra alkalmas. A 'Cigány' meggyek szintén savanykás ízérzettel rendelkeznek 


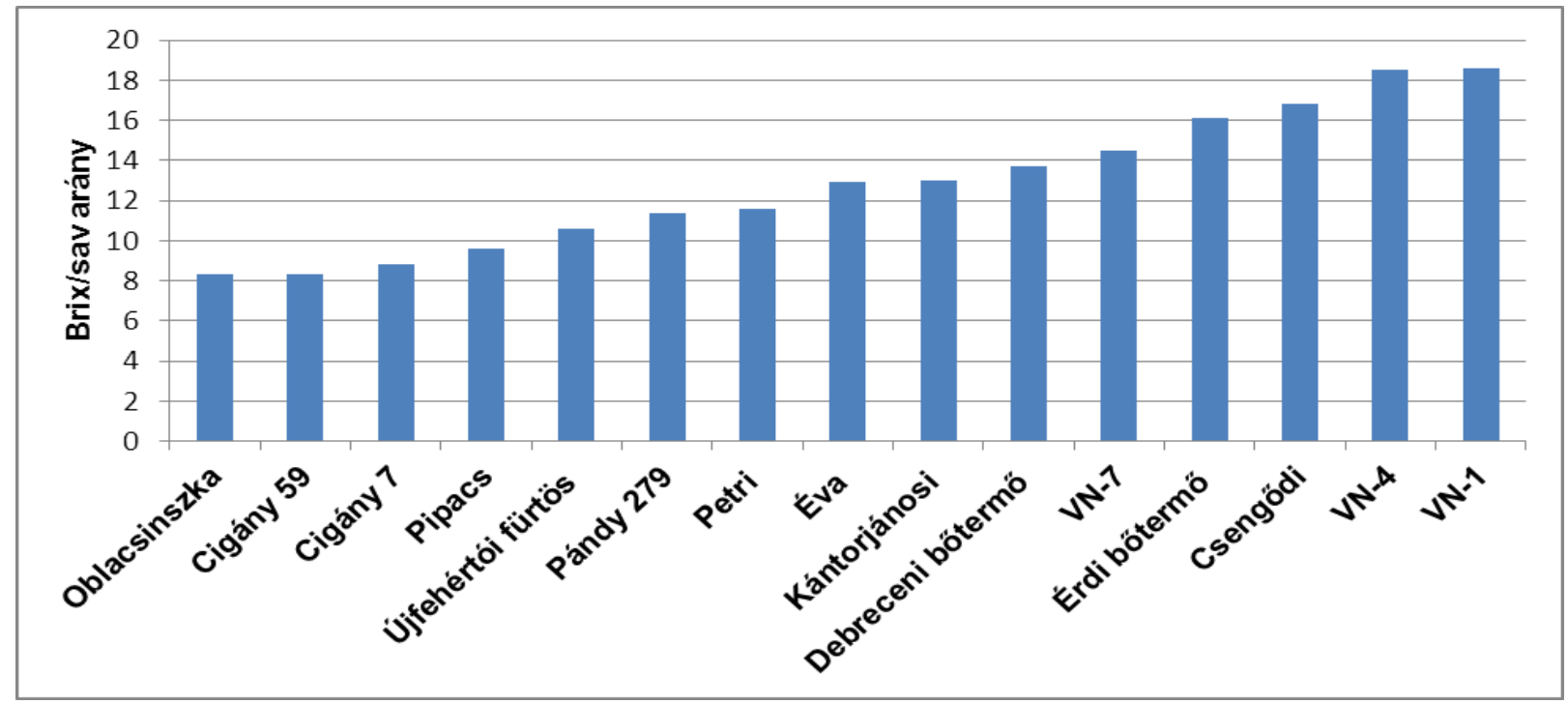

45 .ábra.: Különböző meggy fajták Brix/sav aránya növekvő sorrendben

A 'Petri' és a 'Pándy' megyek szintén savanykásabbak, de lágyabb, zamatosabb ízérzettel az alacsonyabb savtartalom miatt. Az előbbihez hasonló, de a kedvezőbb a brix/sav aránya az 'Újfehértói fürtös' fajtának. Édes ízű csoport a ' Kántorjánosi 3', 'Éva' és a 'VN' fajtajelölt meggy a relatív magas szárazanyag-tartalom és ahhoz képest alacsony savtartalom miatt. Legkedvezőbb Brix/sav arányú fajták harmonikus ízérzetet biztosítanak, mint a 'Csengődi', 'Debreceni bötermö', 'Érdi bötermö' fajták.

9/a táblázat: Ízérzet alkulása a Brix/sav arány függvényében

\begin{tabular}{lrrrr} 
& \multicolumn{2}{c}{$\begin{array}{c}\text { Savtartalom \% } \\
\text { pH 8,1 }\end{array}$} & \multicolumn{1}{c}{ Brix fok } & \multicolumn{1}{c}{ Brix/sav } \\
Csengödi & 0,93 & 15,7 & 16,8 \\
Érdi bötermő & 1 & 16,1 & 16,1 \\
VN-4 & 1 & 18,5 & 18,5 \\
VN-1 & 1,1 & 20,5 & 18,6 \\
VN-7 & 1,1 & 16 & 14,5 \\
Debreceni bötermő & 1,2 & 16,4 & 13,7 \\
Petri & 1,4 & 16,2 & 11,6 \\
Kántorjánosi 3 & 1,4 & 18,2 & 13 \\
Éva & 1,4 & 18 & 12,9 \\
Pándy 279 & 1,4 & 16 & 11,4 \\
Újfehértói fürtös & 1,7 & 18 & 10,6 \\
Oblacsinszka & 2 & 16,6 & 8,3 \\
Pipacs & 2,1 & 20,2 & 9,6 \\
Cigány 59 & $\mathbf{2}$ & 16,6 & 8,3 \\
Cigány 7 & 1,9 & 16,7 & 8,8
\end{tabular}

Lila: édeskés, Sárga: harmónikus, Kék: savanyú, Piros: savanykás, fanyar, Zöld: harmónikus zamat 
9/b táblázat.: Ízérzet alkulása a Brix/sav arány függvényében

\begin{tabular}{|c|c|c|}
\hline \multirow[b]{2}{*}{ sav tartalom \% } & \multicolumn{2}{|r|}{ cukor (Brix \%) } \\
\hline & magas & alacsony \\
\hline közepes-magas & $\begin{array}{l}\text { HARMÓNIKUS: Csengődi, } \\
\text { Debreceni bőtermő, Érdi } \\
\text { bőtermő }\end{array}$ & $\frac{\text { SAVANYÚ, FANYAR*: Cigány 59, Cigány }}{\text { 7, Oblacsinszka, Pipacs, }}$ \\
\hline alacsony & $\begin{array}{l}\text { ÉDESKÉS: Kántorjánosi } \\
3^{* *}, \text { Éva, VN fajtajelölt }\end{array}$ & $\frac{\text { ERÖSEN-SAVAS ÉDES ZAMAT: Pándy }}{279, \text { Újfehértói fürtös, Petri }}$ \\
\hline & & $\begin{array}{l}\text { *savtartalomhoz képest a Brix alacsony } \\
\text { ** Kántorjánosi fajta teljesen érett állapotban }\end{array}$ \\
\hline
\end{tabular}

(Revell (2008) csoportosítása nyomán, saját adatok alapján)

\subsubsection{Cseresznye Brix fok és savtartalom}

Cseresznye esetében csak integrált termesztésü minták álltak rendelkezésre. A vizsgálatom célja az egyes fajták sav- és szárazanyag-tartalma közötti különbségek vizsgálata (46-48. ábra).

A rendelkezésre álló három fajta cseresznye szárazanyag tartalmát (48 ábra) tekintve a fajták között szignifikáns $(\mathrm{p}<0,05)$ különbség van. A 'Firm red' fajta viszonylag magas szárazanyagtartalommal rendelkezik (3 év átlaga 17,3 Brix fok). Ugyanakkor az egyes fajtáknál az értékek egy viszonylag szük sávban mozognak (43. ábra). Pedieri és munkatársai (2004) által mért 2004-es olaszországi integrált termesztésủ cseresznyék szárazanyag-tartalma 11,8 és 21 Brixfok között változott. 


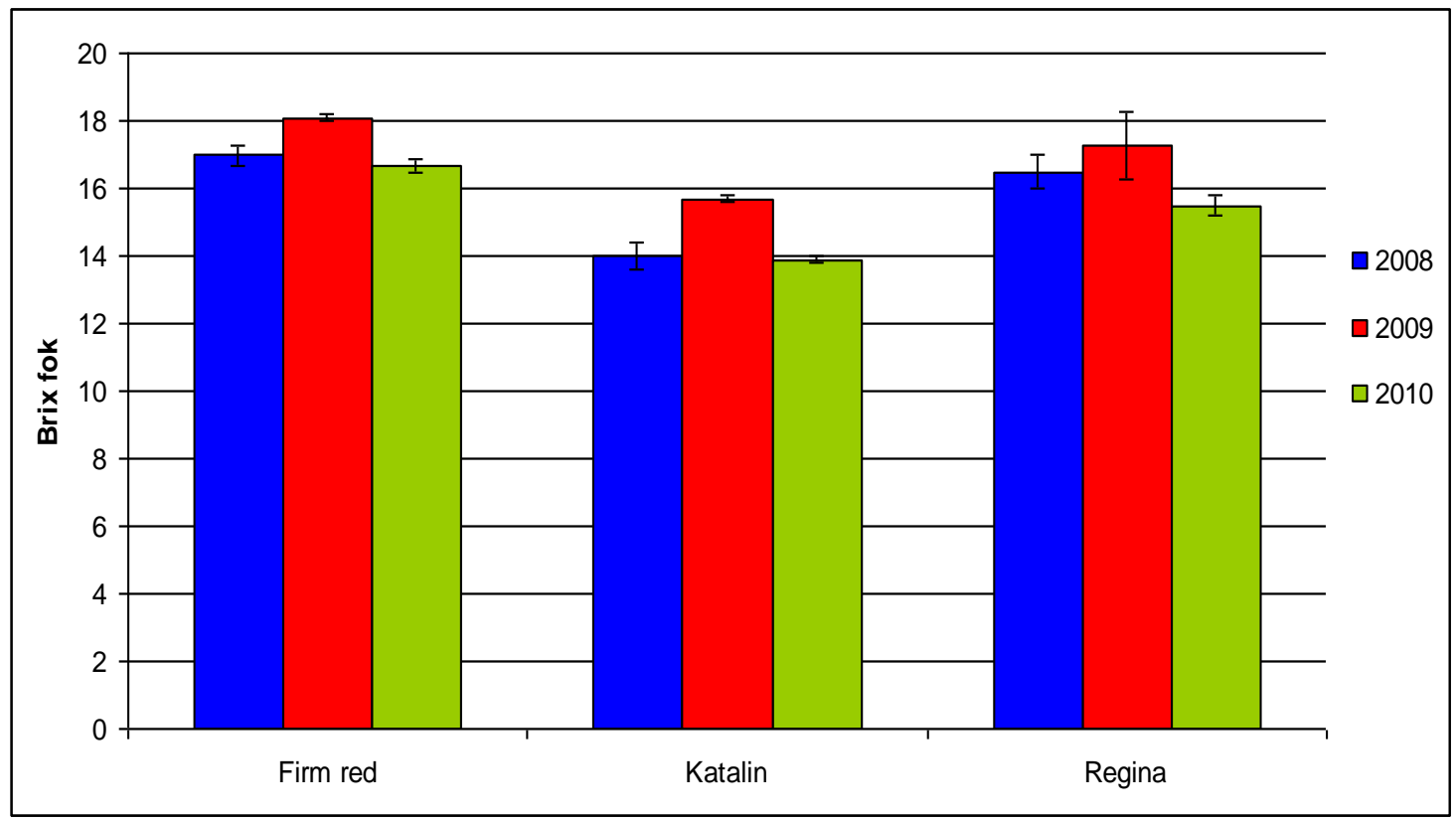

46. ábra:Az egyes cseresznye fajták évjáratonként mért szárazanyag tartalma

Az egyes fajták savtartalmának vizsgálata során megállapítható, hogy a 'Firm red' cseresznyének volt a legmagasabb a savtartalma és a legmagasabb Brix-foka (46-47. ábra)

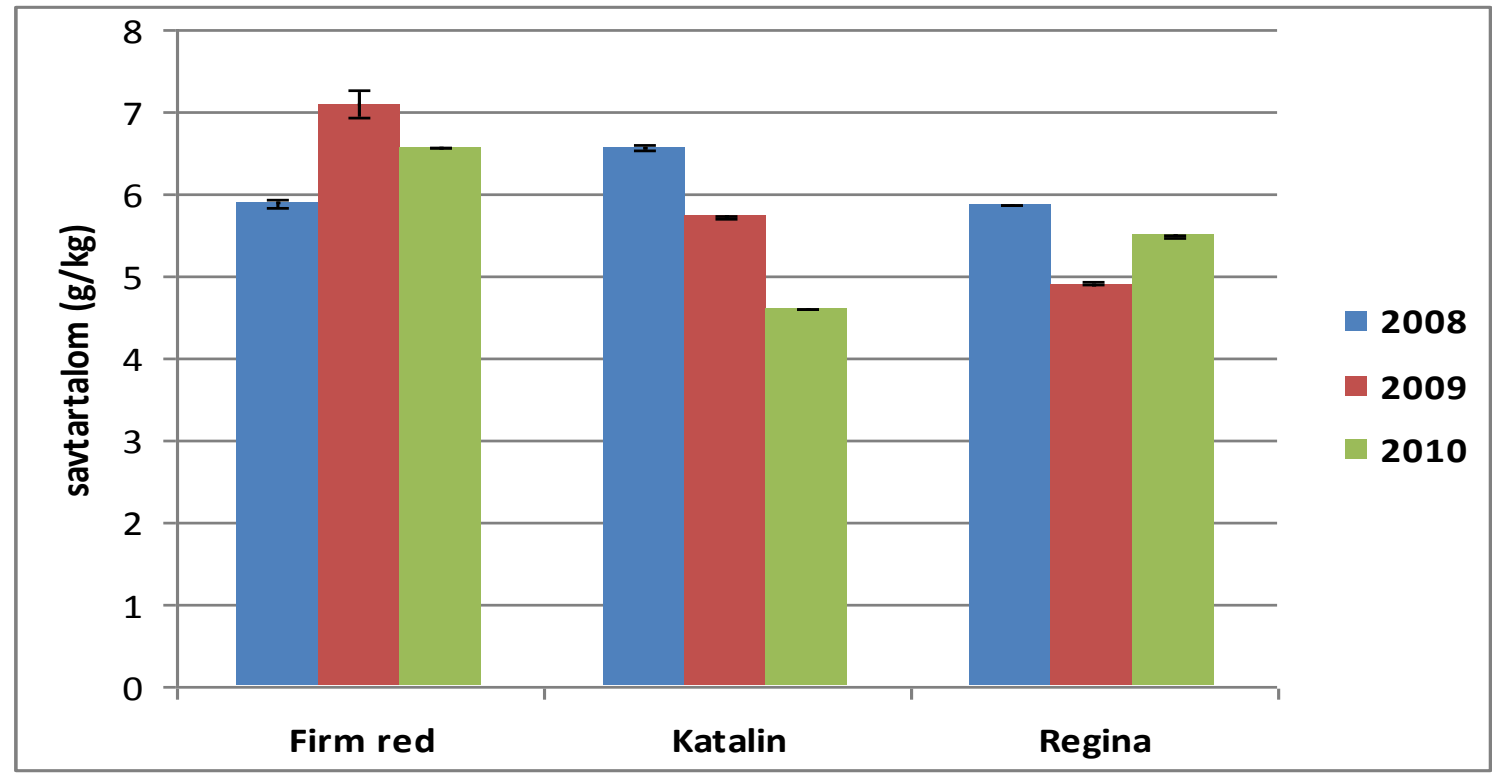

\section{7. ábra: Az egyes fajták évjáratonként mért savtartalma}

A 2010-es év sokéves átlagot meghaladó csapadékos időjárása - mely magasabb savtartalmat eredményez a szakirodalom alapján - jól látszik az eredményekben is. A 'Katalin' fajta savtartalma viszonylag széles sávban mozog, valószínűsíthető az évjárat hatása (47. ábra). Az egyes fajták savtartalmában a különbség azonban nem szignifikáns $(\mathrm{p}<0,05)$. 
A három fajta cseresznye sav-és szárazanyag tartalom átlag eredményeiből vizsgáltuk meg a Brix/sav arány alakulását (48. ábra).
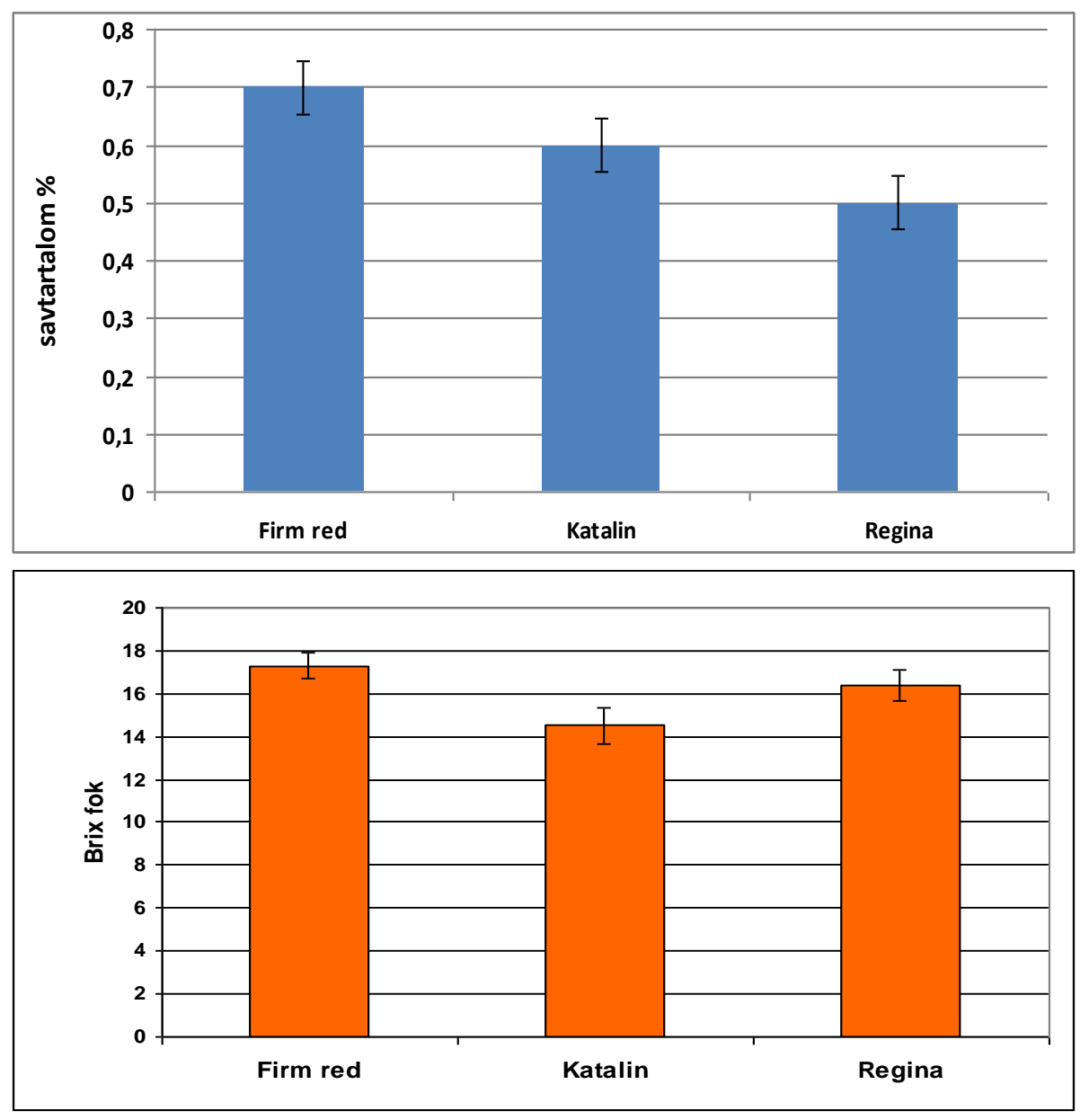

48. ábra: cseresznye minták három éves átlagos savtartalma (A) és szárazanyag-tartalma (B) fajtánként

10. táblázat: Cseresznye minták brix/sav aránya

\begin{tabular}{llrrr} 
Fajta & $\begin{array}{l}\text { átlagos szárazanyag-tartalom } \\
\text { (Brix fok) }\end{array}$ & \multicolumn{1}{l}{$\begin{array}{l}\text { átlagos } \\
\text { savtartalom (\%) }\end{array}$} & Brix/sav \\
Firm red & 17,3 & 0,67 & 25,8 \\
Katalin & 14,5 & 0,57 & 25,4 \\
Regina & 16,4 & 0,57 & 28,7
\end{tabular}

A magas Brix/sav arány a viszonylag magas Brix fokból és alacsony savtartalomból adódik. A legédesebb ízzel a 'Regina' (Brix/sav arány 29) fajta rendelkezik, a viszonylag magas Brixfoknak és alacsonyabb savtartalomnak köszönhetően (10. táblázat) 


\subsubsection{Alma Brix fok és savtartalom}

Összesen 33 fajta alma sav-és szárazanyag tartalmát vizsgáltam. A három évjáratban mért szárazanyag-tartalom eredményeinél a bio és integrált párokat is feltüntettem (49. ábra). A bio és integrált termesztési mód között nincs szignifikáns $(\mathrm{p}<0,05)$ különbség, viszont az egyes évjáratok közötti különbség nyomon követhető (49.-50. ábra). Az almánál is jelentős a 2009-es év kedvező időjárásának hatása (50. ábra). A 2009-es évjáratban mért Brix-fok minden fajtánál és termesztési módnál legalább 5\%-al magasabbak, mint a 2010-es, szélsőséges és rendkívül csapadékos évben. Az egyes éváratok közötti különbség a szárazanyag-tartalmat tekintve szignifikáns $(\mathrm{p}<0,05)$. A legmagasabb értékeket 2009-ben mértem.

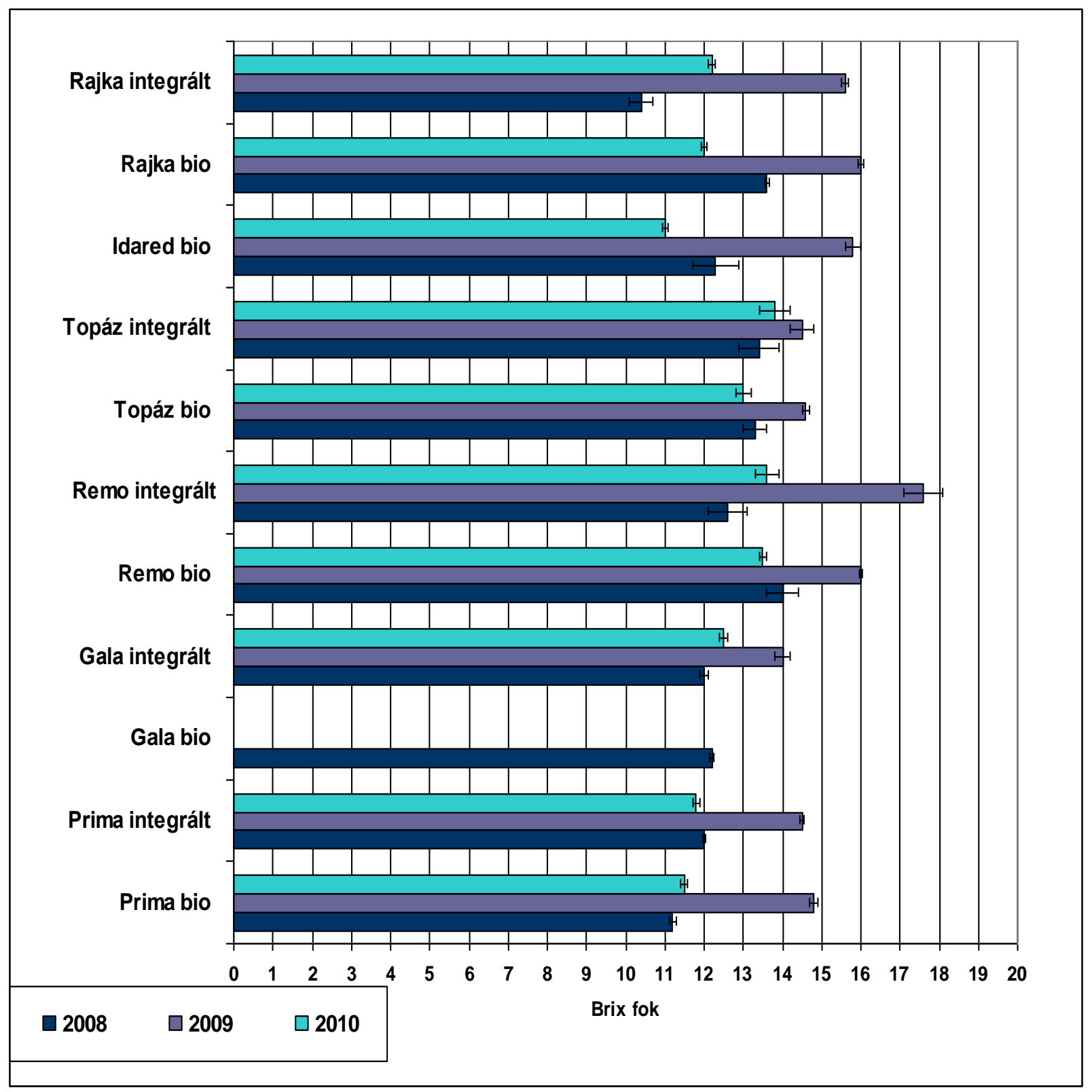

49. ábra: alma minták szárazanyag-tartalma évjáratonként bio és integrált pároknál 


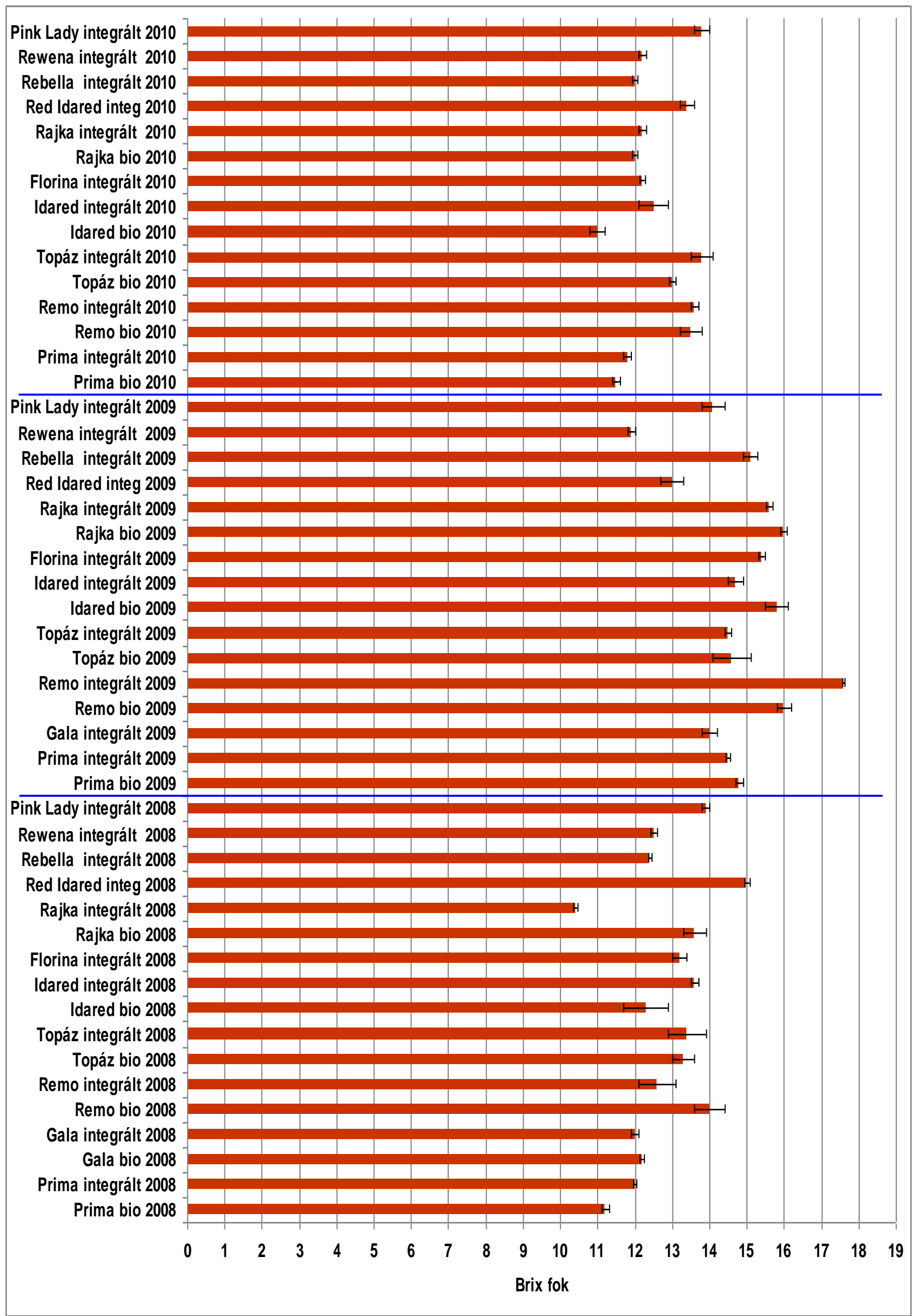

50. ábra: alma fajták szárazanyag-tartalma az egyes évjáratokban 
Vizsgáltam az egyes fajták szárazanyag-tartalmát, átlagolva a 2008-2010 években kapott eredményeket (51. ábra). Ebben az esetben eltekintettem az ökológiai termesztési módtól, mivel kevés fajtánál volt lehetőség a bio és integrált minták párhuzamos vizsgálatára. Az átlagolt eredmények alapján (50. ábra) a 'Jonagold' (15,2 Brix-fok), 'Pinova' (15,1 Brix-fok) és a 'Rubinette' (15,2 Brix-fok) szárazanyag-tartalma kiemelkedő. A legalacsonyabb értékeket a 'Campbell' (11,6 Brix-fok) és a 'Sampion' (11,8 Brix-fok), fajtáknál kaptam. Papp és munkatársai (2011) mérései szerint az integrált termesztésű 'Jonathan' (11,2 Brix-fok) és 'Idared '(13,3 Brix-fok) alma szárazanyag tartalma hasonlóan alakult a dolgozatban szereplö értékekhez.

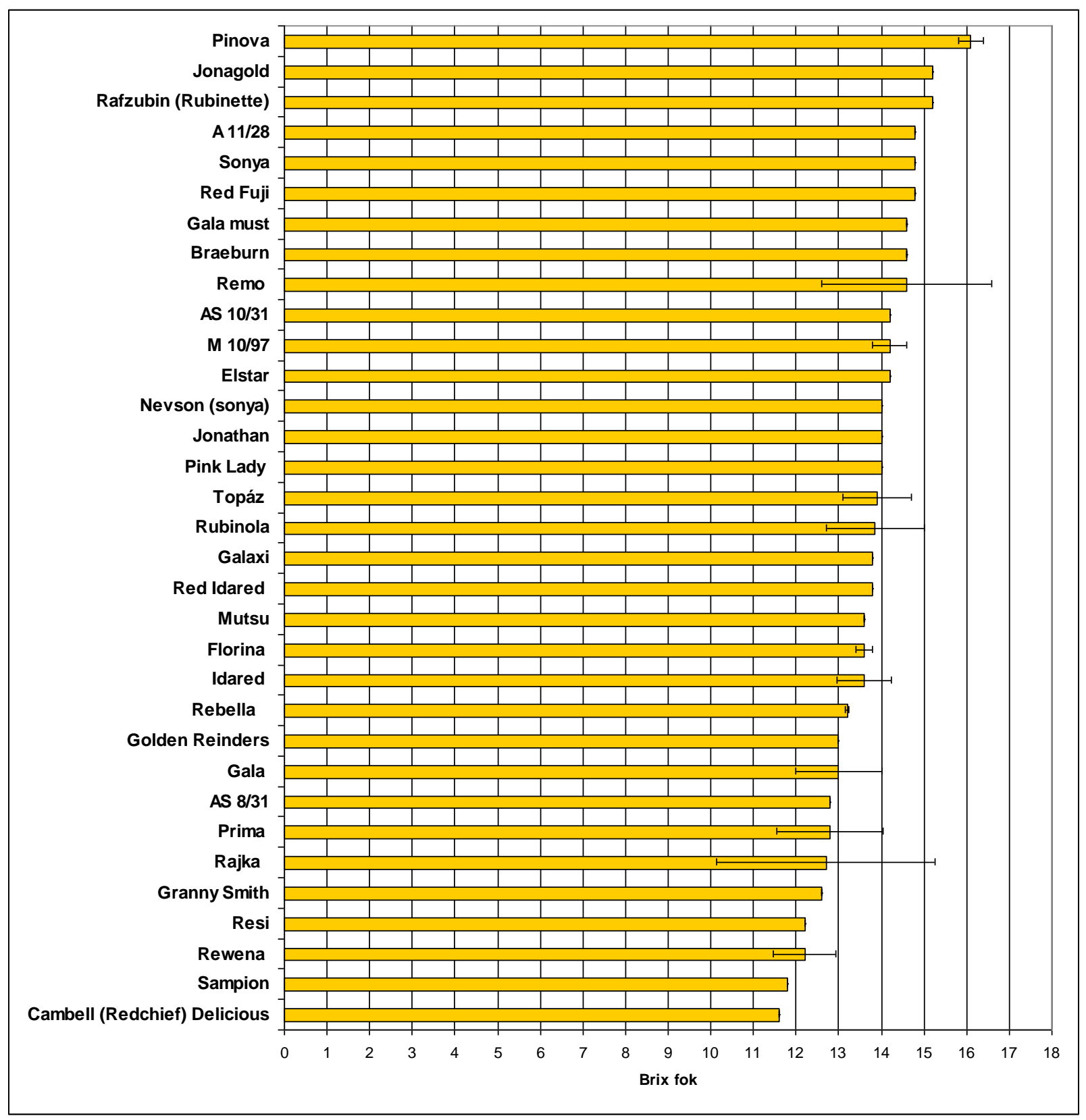


51. ábra: alma minták átlagos (2008-2009-2010) szárazanyag tartalma az integrált termesztésü fajtáknál

Az almák savtartalmában a termesztési módtól függően - bio és integrált párok - nincs szignifikáns ( $\mathrm{p}<0,05)$ különbség, (kivéve az 'Idared' fajta esetében) (52. ábra). Az egyes fajták között nagyobb a különbség, mint a termesztési módból származó esetleges különbség. Nagyobb hatással van az évjárat illetve az időjárás hatása (53. ábra), mint a termesztési mód. Róth és munkatársai (2007) vizsgálták a különböző termesztési (ökológiai és integrált) módból származó almák savasságát és azt találták, hogy nincs termesztési módból származó szignifikáns $(\mathrm{p}<0,05)$ különbség a savtartalom szempontjából. Az évenkénti savtartalom ingadozás (53. ábra) megfigyelhetőbb és követhetőbb, mint a termesztési módból származó különbség. Az egyes évjáratok között a savtartalmat tekintve szignifikáns $(p<0,05)$ a különbség. A legmagasabb értékeket - valószínűleg a sok csapadék hatására - 2010-ben mértem.

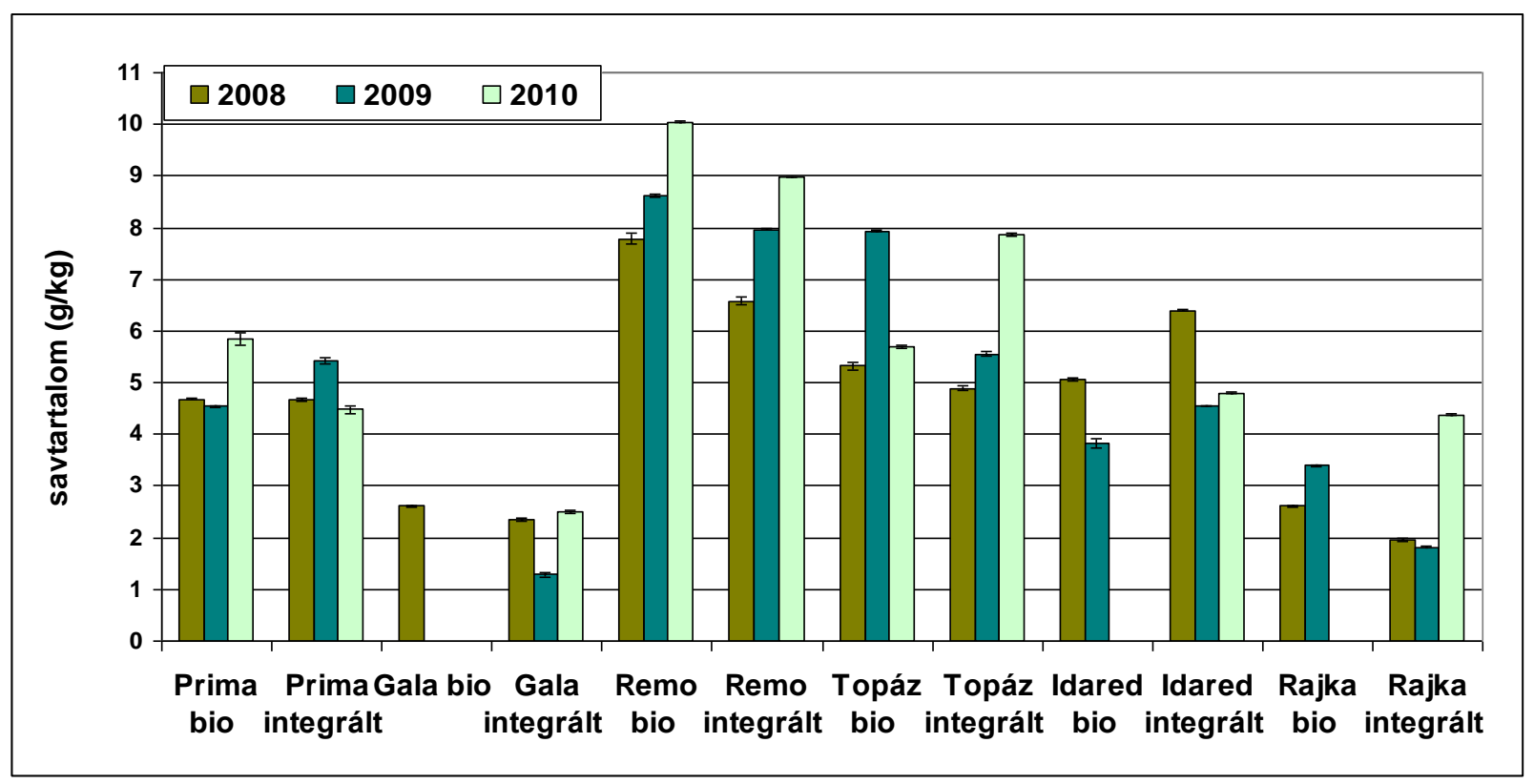

52. ábra: alma minták savtartalma évjáratonként bio és integrált pároknál

Fajta szerint vizsgálva (54. ábra) jelentős eltérések lehetnek. Az egyes fajták savtartalom ingadozása nagyobb, mint a szárazanyag-tartalmakban mért különbség. Az ábrázolt eredmények a három év átlagát mutatják (54. ábra). A legmagasabb a savtartalma a 'Remo' (7,85 g/kg), 'Topáz' (6,1 g/kg) és 'Idared' (5,25 g/kg) fajtáknak, legalacsonyabb, pedig a 'Nevson' (0,79 g/kg), 'Campbell Delicious' (1,03 g/kg) és 'Sampion' (1,33 g/kg) fajtáknak. A kutatásba vont almafajták között alacsonyabb savtartalmú almákra jellemző, hogy a 'Golden Delicious' illetve 'Red Delicious' fajtától származnak, a nagyobb savtartalommal rendelkezők pedig az 'Idared' illetve 'Jonathan' fajtáktól. 


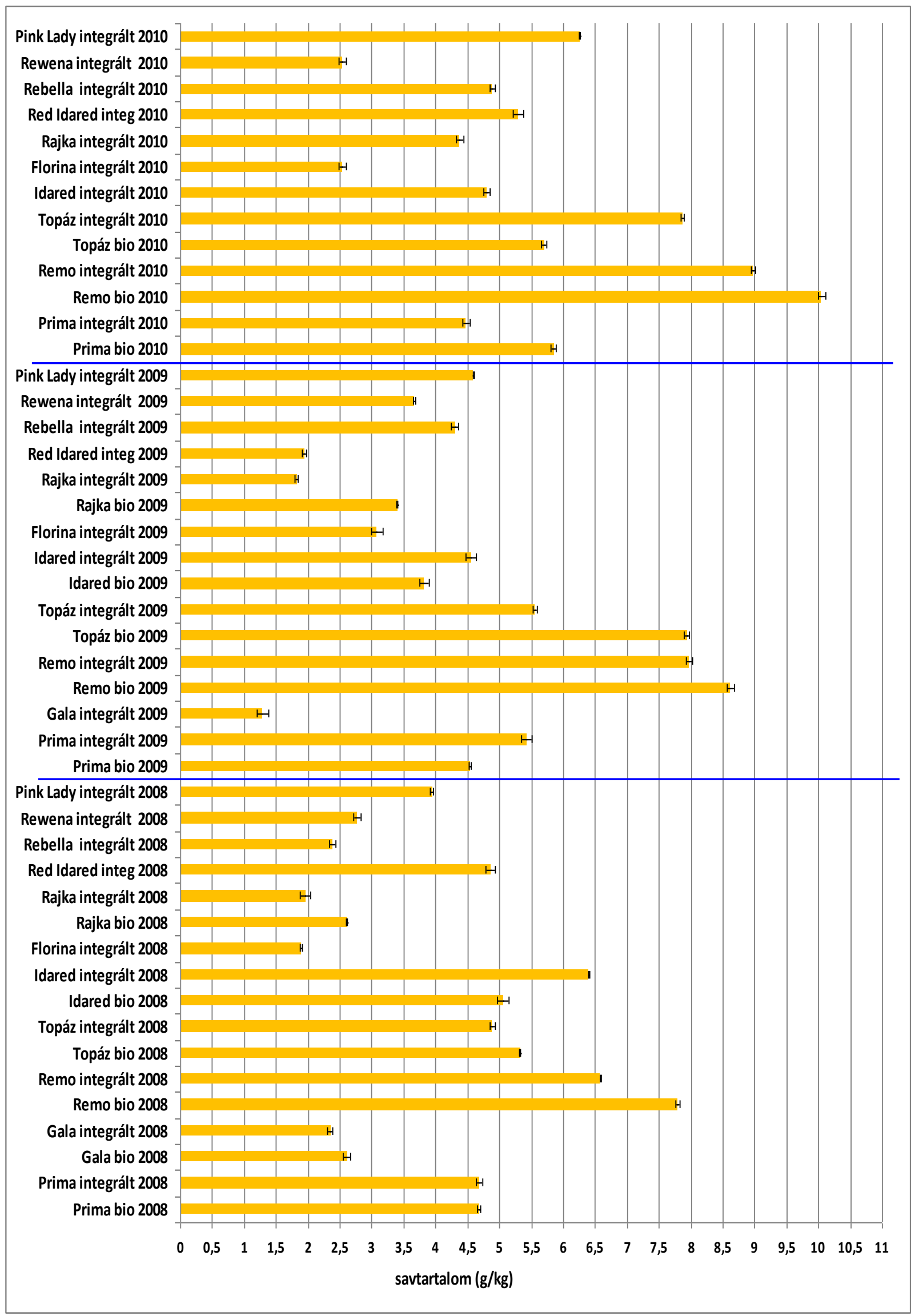

53. ábra: alma minták savtartalma az egyes évjáratokban 


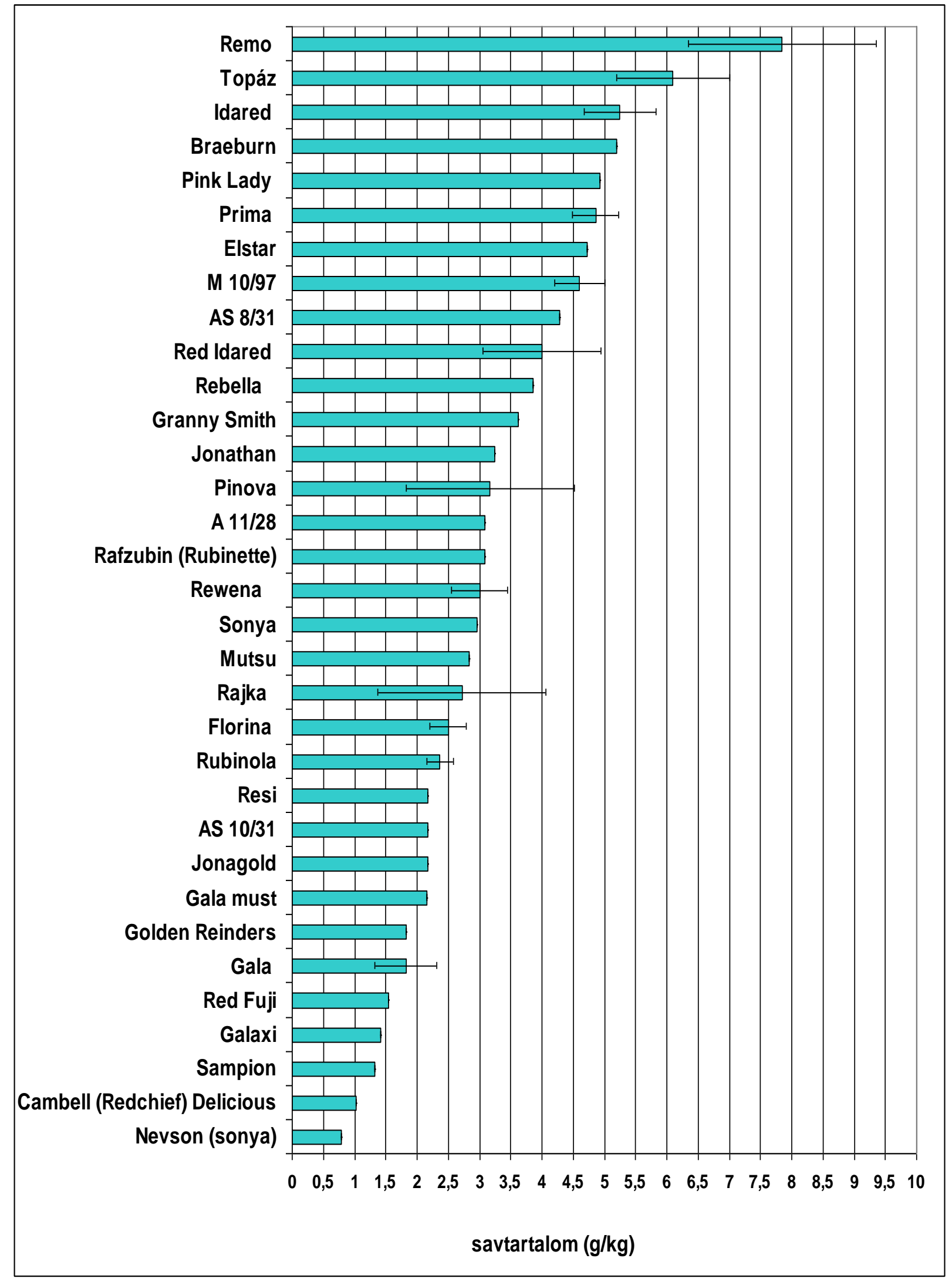

54. ábra: alma minták átlagos (2008-2009-2010) savtartalma az integrált termesztésű fajtáknál 
Összesen 33 fajta sav-és szárazanyag tartalom átlag eredményeiből vizsgáltam meg a Brix/sav arány alakulását. A fajták között a savtartalomban jelentősebb eltérések mutatkoznak, mint a szárazanyag-tartalomban. A savtartalom és Brix-fok egymáshoz viszonyított aránya szerint négy csoportot különíthetünk el (11. táblázat). Cukor-sav arányuk alapján a legédesebb íze a 'Campbell Delicious' (11,8, 1,03 g/kg), 'Sampion' és, 'Gala' csoportnak volt, amelyeknél az alacsony savtartalom szintén alacsony szárazanyag-tartalommal párosult. A második csoportot az előzőhöz képest magasabb refrakció érték jellemezte, amely édeskés ízt kölcsönzött a 'Red Fuji' (14,8; 1,54g/kg), a 'Jonagold' (15,2; 2,17 g/kg), a 'Pinova' és a csoport többi fajtájának. Ebbe a csoportba tartozik az AS 11/28 és AS 10/31 újfehértói nemesített fajta is. Az iparban jól hasznosítható fajták magas sav-és szárazanyag tartalommal rendelkeznek. Ilyenek a 'Jonathan' $(14,0 ; 3,25$ g/kg), 'Elstar', 'Braeburn', 'Topáz' és 'Remo' fajták. Alacsonyabb, illetve közepes, esetleg magas szárazanyag-tartalom és ehhez képest magas sav-tartalom jellemzi az 'Idared' (13,6; 5,25 g/kg), 'Pink Lady', 'Rajka' és a csoportban lévő többi fajtákat. Ezeknél inkább a savanykás aroma dominál. Az 'Idared '(13,6) szárazanyag tartalmát tekintve nem sokban tér el a 'Jonathan' (14) fajtától, azonban a savtartalma a 'Jonathan'-hoz képest magasabb, ezért savanykás alapíz jellemzi.

\section{1. táblázat: Almafajták csoportosítása Brix/sav arány szerint}

\begin{tabular}{|c|c|c|}
\hline \multirow{2}{*}{ savtartalom } & $\begin{array}{l}\text { Brix \% } \\
\text { magas }\end{array}$ & alacsony \\
\hline & Jonathan, M10/97, Elstar, & Resi, Rajka, Rewena, Idared, \\
\hline \multirow{4}{*}{ magas } & Braeburn, Topáz, Remo & Granny Smith, Rebella, Pink \\
\hline & & Lady, Prima, AS 8/31 \\
\hline & Galaxi, Red Fuji, Jonagold, & Campbell Delicious, Sampion, \\
\hline & GalaMust, Rubinola, & Gala, Golden Reinders, Florina, \\
\hline alacsony & $\begin{array}{l}\text { Pinova, Sonya, Rubinette, } \\
\text { AS 11/28, AS 10/31 }\end{array}$ & Mutsu \\
\hline
\end{tabular}

(Revell (2008) csoportosítása nyomán, saját adatok alapján) 


\subsubsection{Körte Brix fok és savtartalom}

Összesen öt körtefajta vizsgálatára került sor, melyböl egy fajta ('Concorde') mintának csak a 2009-es évből vannak mérési adatai. Csak integrált termesztésű minták álltak rendelkezésre a vizsgálathoz. A savtartalom a körték esetében volt a legalacsonyabb az összes gyümölcs közül (1,1-3,34 g/kg). Az ötfajta körte sav-és szárazanyag-tartalmát százalékban kifejezve minden egyes évjáratra vonatkoztatva megadtam (55.-56. ábra). Sem a Brix-fok, sem a savtartalom alapján nincs szignifikáns $(\mathrm{p}<0,05)$ különbség az egyes fajták között a körték esetében. A legmagasabb savtartalom értéket a 'Vilmos' körténél mértem 2009-ben (0,6\%), míg a legalacsonyabbat a 'Conference' fajtánál (0,2\%) szintén 2009-ben. Az utóbbi fajtának a legmagasabb a Brix foka, ez alapján és a szakirodalommal összhangban, igen édes fajta. Legalacsonyabb szárazanyag-tartalomat a 'Fétel apát' fajtánál mértem. Ez alacsony kalória tartalmú, diétára alkalmas fajta. Ezt a tulajdonságot közvetetten - savtartalom és Brix fok alakításával - az évjárat, illetve időjárás befolyásolhatja.

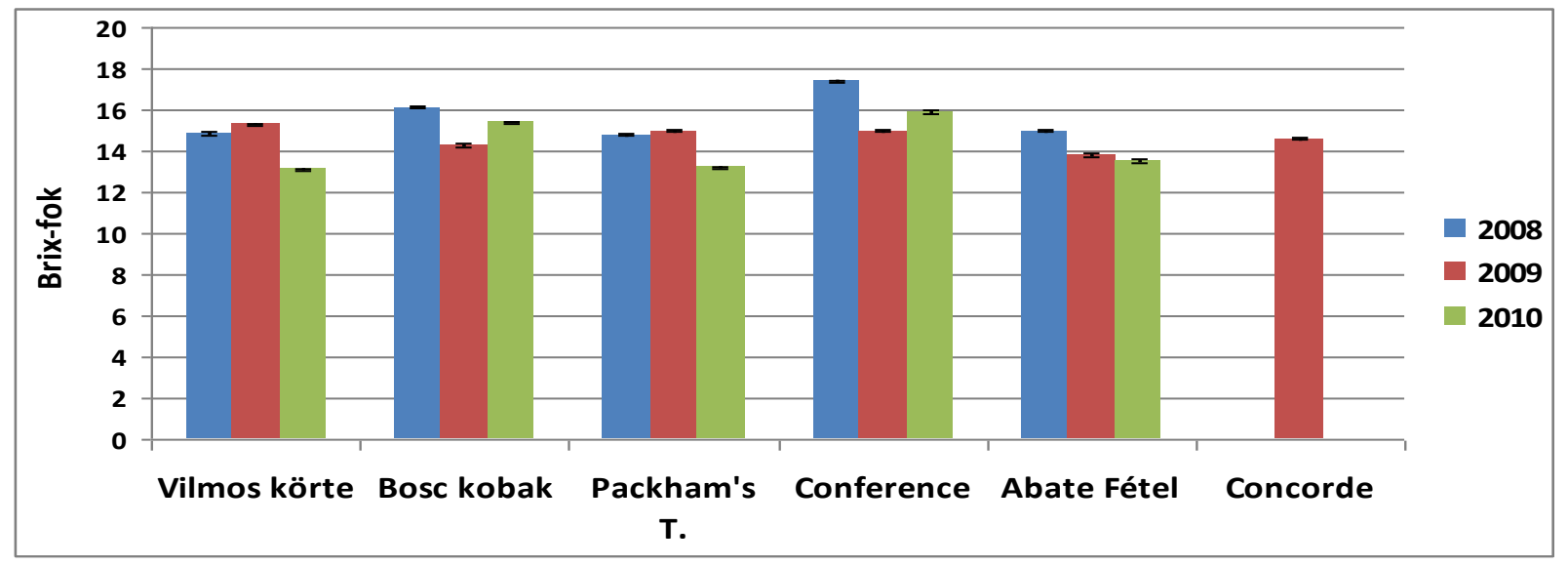

55. ábra: körte minták szárazanyag-tartalma a 2008-2009-2010-es évjáratból

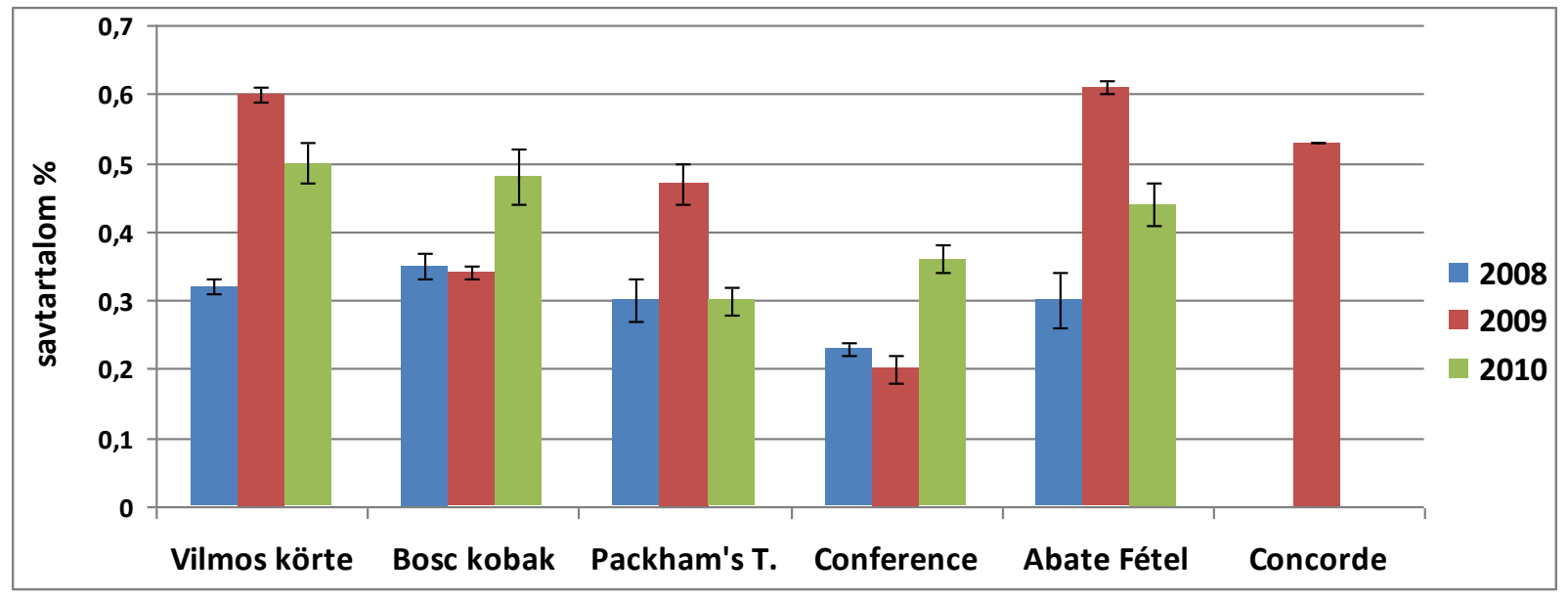

56. ábra: körte minták savtartalma a 2008-2009-2010-es évjáratból 


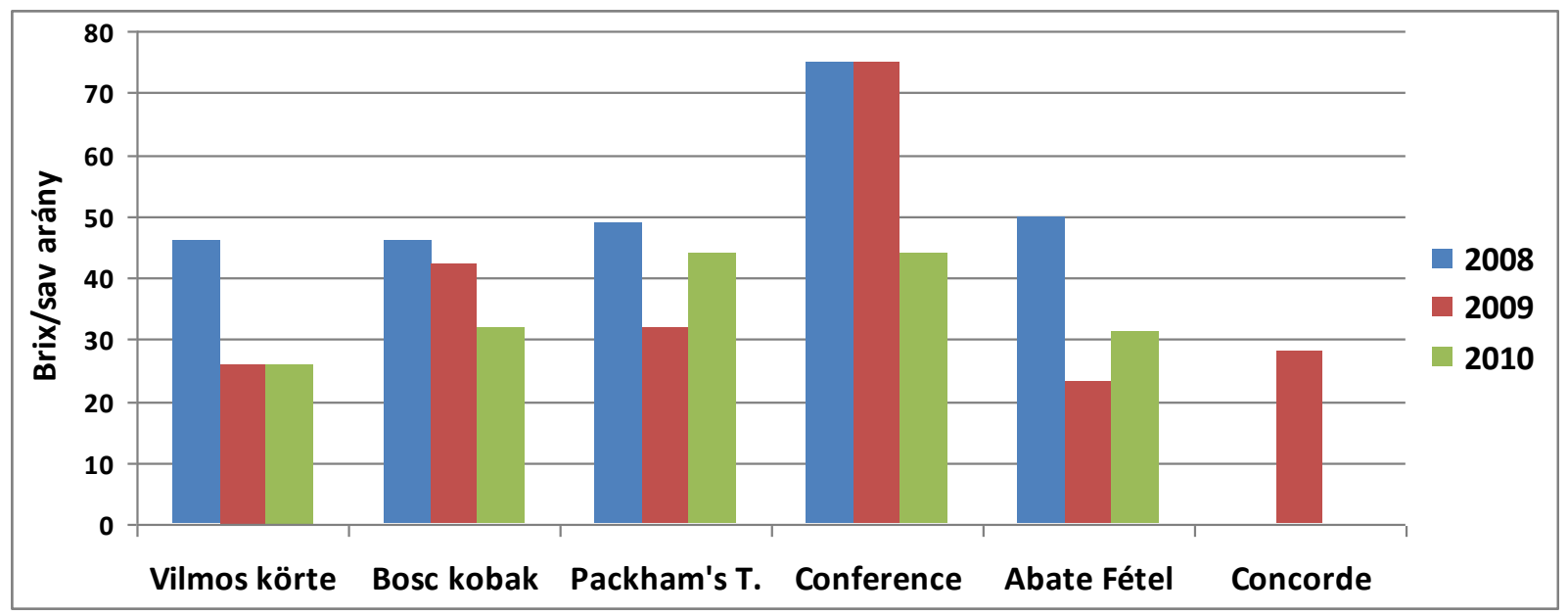

57. ábra: körte minták cukor-sav aránya a 2008-2009-2010-es évjáratból

A cukor-sav arány eredmények alapján a körténél is csoportosítani lehetett (12. táblázat) az ízérzet szerint. Leginkább harmonikus, se nem túl savas, se nem túl édes ízü körte a 'Bosc kobak'. A 'Vilmos' körte inkább savanykás jellegü, míg a 'Conference’ édes íze a 2010-es esős, változékony időjárásának következtében nem érvényesült.

\section{2. táblázat: körték csoportosítása sav-és szárazanyag-tartalom aránya szerint}

\begin{tabular}{|c|c|c|c|c|}
\hline & $\begin{array}{c}\text { Brix fok } \\
\%\end{array}$ & & & \\
\hline Vilmos körte 2008 & 14,9 & Vilmos körte 2008 & 0,32 & édes \\
\hline Vilmos körte 2009 & 15,3 & Vilmos körte 2009 & 0,6 & harmónikus \\
\hline Vilmos körte 2010 & 13,1 & Vilmos körte 2010 & 0,5 & kevésbé édes \\
\hline Bosc kobak 2008 & 16,1 & Bosc kobak 2008 & 0,35 & \\
\hline Bosc kobak 2009 & 14,3 & Bosc kobak 2009 & 0,34 & \\
\hline Bosc kobak 2010 & 15,4 & Bosc kobak 2010 & 0,48 & \\
\hline Packham's Triumph 2008 & 14,8 & Packham's Triumph 2008 & 0,3 & \\
\hline Packham's Triumph 2009 & 15 & Packham's Triumph 2009 & 0,47 & \\
\hline Packham's Triumph 2010 & 13,2 & Packham's Triumph 2010 & 0,3 & \\
\hline Conference 2008 & 17,4 & Conference 2008 & 0,23 & \\
\hline Conference 2009 & 15 & Conference 2009 & 0,2 & \\
\hline Conference 2010 & 15,9 & Conference 2010 & 0,36 & \\
\hline Fétel apát 2008 & 15 & Fétel apát 2008 & 0,3 & \\
\hline Fétel apát 2009 & 13,8 & Fétel apát 2009 & 0,61 & \\
\hline Fétel apát 2010 & 13,5 & Fétel apát 2010 & 0,44 & \\
\hline
\end{tabular}

A Brix/sav arányt kismértékben módosítja az évjárat hatása, de a fajtára jellemző értékek állandónak mondhatóak. A 'Conference' fajtának édeskés karaktert kölcsönző magas Brix érték és a vizsgált fajtához képest alacsonyabb savtartalom szinte mindhárom évjáratban jellemző (57. ábra). 
A vizsgálatba bevont gyümölcsfajták sav-és szárazanyagtartalmának gyakorisági eloszlásai

A megvizsgált négy fajta gyümölcs (alma, körte, meggy, cseresznye) sav-és szárazanyagtartalom összehasonlítását az egyes paraméterekre vonatkozó gyakorisági eloszlások mutatják (58-59.ábra). Az eloszlásokat azért tartottam célszerünek, mert így áttekinthetőbbé válnak az egyes gyümölcsökre jellemző paraméterek. A meggy és alma esetében a szélesebb tartományokhoz hozzájárult az is, hogy almából 33 fajta, meggyből 15 fajta, míg a körtéből öt fajta, illetve a cseresznyéből csak három fajta vizsgálatára volt lehetőség.

58. ábra: A vizsgált gyümölcsök szárazanyag tartalma

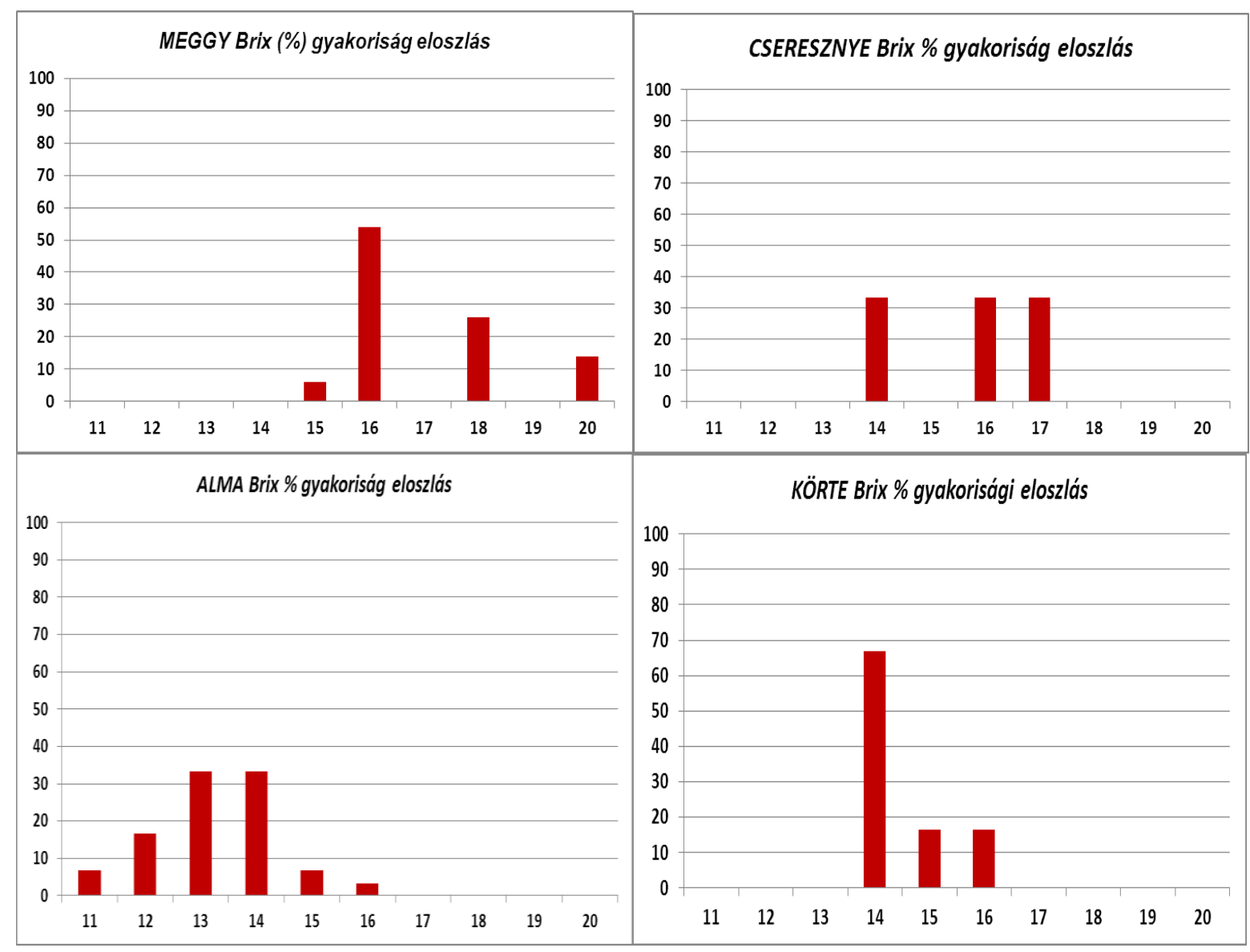

A legmagasabb szárazanyagtartalmat a meggy (18-20\%), illetve a cseresznye (16-17\%) esetében mértük. A meggyek 40\%-a a 18-20\% Brix-fok tartományba, illetve a cseresznyénél a gyümölcsök 66\% a 16-17\% Brix-fok tartományba esik. Az almánál az átlagos (a minták 66\%) Brix-fok 13-14\% körül van, míg a körténél a vizsgált minták 67\%-a 14\%-os Brix-fokkal rendelkezik. 
A savtartalom alakulását (59. ábra) tekintve a meggyek kiemelkedően magas savtartalmúak a többi gyümölcshöz képest. Az eloszlás viszonylag széles sávban mozog, mivel az egyes fajták között is nagy különbségeket találtunk. A minták egy részénél (28\%) 13-14 g/kg savtartalmat mértem, míg igen magas $21 \mathrm{~g} / \mathrm{kg}$ savtartalom mérhető a minták egy ötödénél. A következő a cseresznye, melynek savtartalma elmarad rokonától, a meggytől. Az összes minta savtartalma 5 és $6 \mathrm{~g} / \mathrm{kg}$ között alakult. Az almák esetében jól látható a Gauss-görbe. A minták zöme a 2-3g/kg savtartalommal rendelkezett. A legalacsonyabb savtartalmat a körténél mértem. A vizsgált öt körtefajta savtartalma 1-2 g/kg. A meggy és alma esetében a szélesebb savtartalom tartományhoz hozzájárult a vizsgált fajták nagy száma is.

\section{9. ábra: A vizsgált gyümölcsök savtartalma}

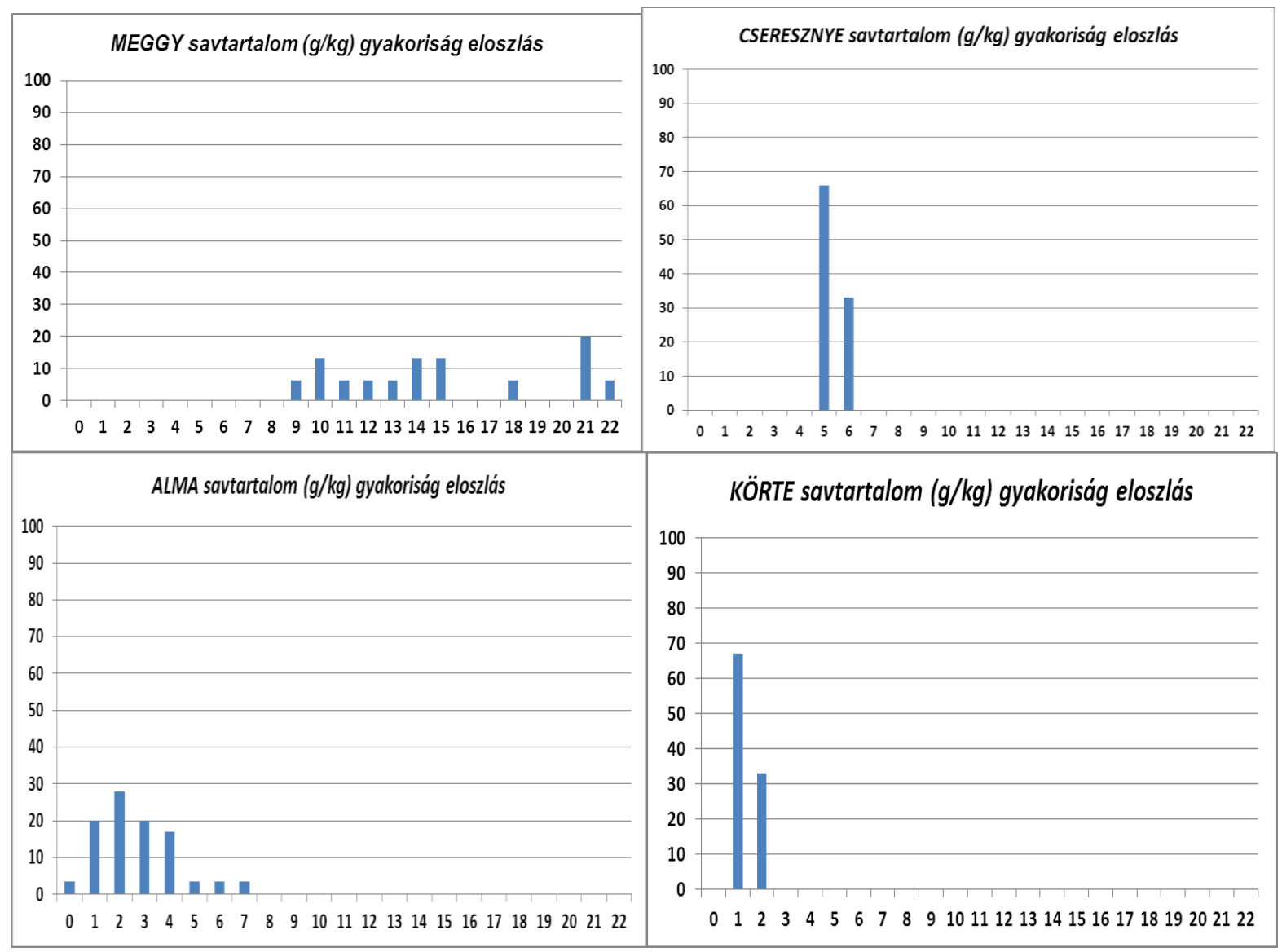




\title{
6.3 Biológiailag aktív anyagok a csonthéjas gyümölcsökben
}

\author{
POLIFENOL, ANTOCIANIN, ANTIOXIDÁNS KAPACITÁS
}

\subsubsection{Meggy biológiailag aktív vegyületei}

Összesen 15 fajta meggy polifenol tartalmának vizsgálatára került sor. A fajták többségéből két évjáratban állt rendelkezésre minta, míg egy kisebb részükből, illetve a bio és integrált párokból mindhárom évjáratból rendelkezésre állnak mérési adatok.

Kerestem a választ a fajta, a termesztési mód illetve az évjáratból adódó különbségekre polifenol-tartalomra és antioxidáns kapacitásra vonatkoztatva.

A meggy fajták mérési eredményeit évjáratonként átlagoltam és feltüntettem a leginkább jellemző polifenol tartalom (61. ábra) és antioxidáns kapacitás alakulását (62. ábra) az egyes fajtákban, figyelmen kívül hagyva az évjárat hatását. A polifenol tartalom és az antioxidáns kapacitás között szoros korreláció mutatható ki (60. ábra). Az összefüggéseket leíró görbe a korrelációs koefficiense (r) érték 0,9970, mely szoros kapcsolatot jellemez. A minták közül a 'Pipacs' meggynek kiemelkedően magas a polifenol tartalma és antioxidáns kapacitása. Nem kiemelkedő, de magas polifenol tartalommal rendelkezik- és ezzel arányosan antioxidáns kapacitással rendelkeznek - a 'VN-1', 'Oblacsinszka' és 'Cigány' megyek.

Az 'Érdi bötermö', 'Kántorjánosi 3', 'Debreceni bötermö' és 'Újfehértói fürtös' esetében külön is ábrázoltam (63. ábra) a bio és integrált termesztésű mintapárokat. A két termesztési mód között a három évjáratot összesítve nem találtam szignifikáns $(\mathrm{p}<0,05)$ különbséget.

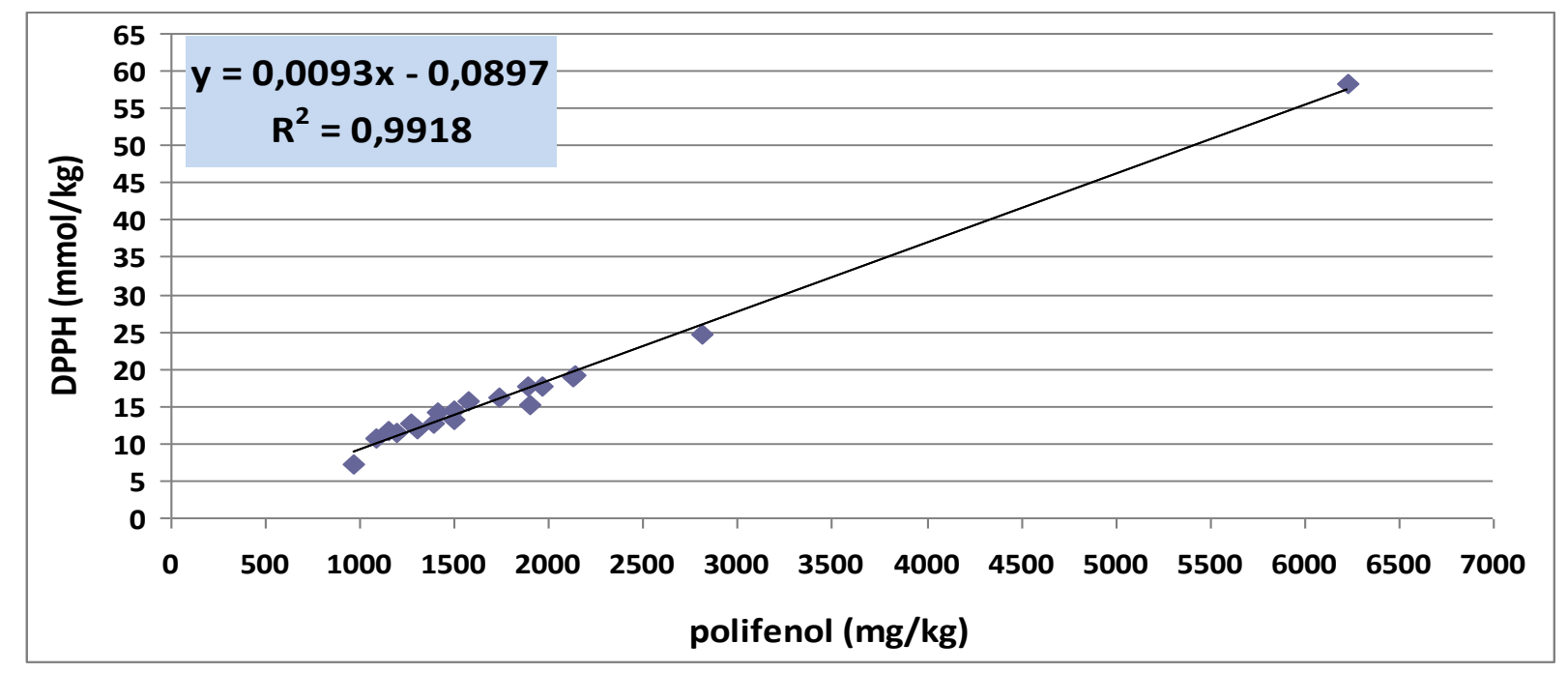

60. ábra: Antioxidáns kapacitás és polifenol tartalom korrelációja az átlagolt adatokból 


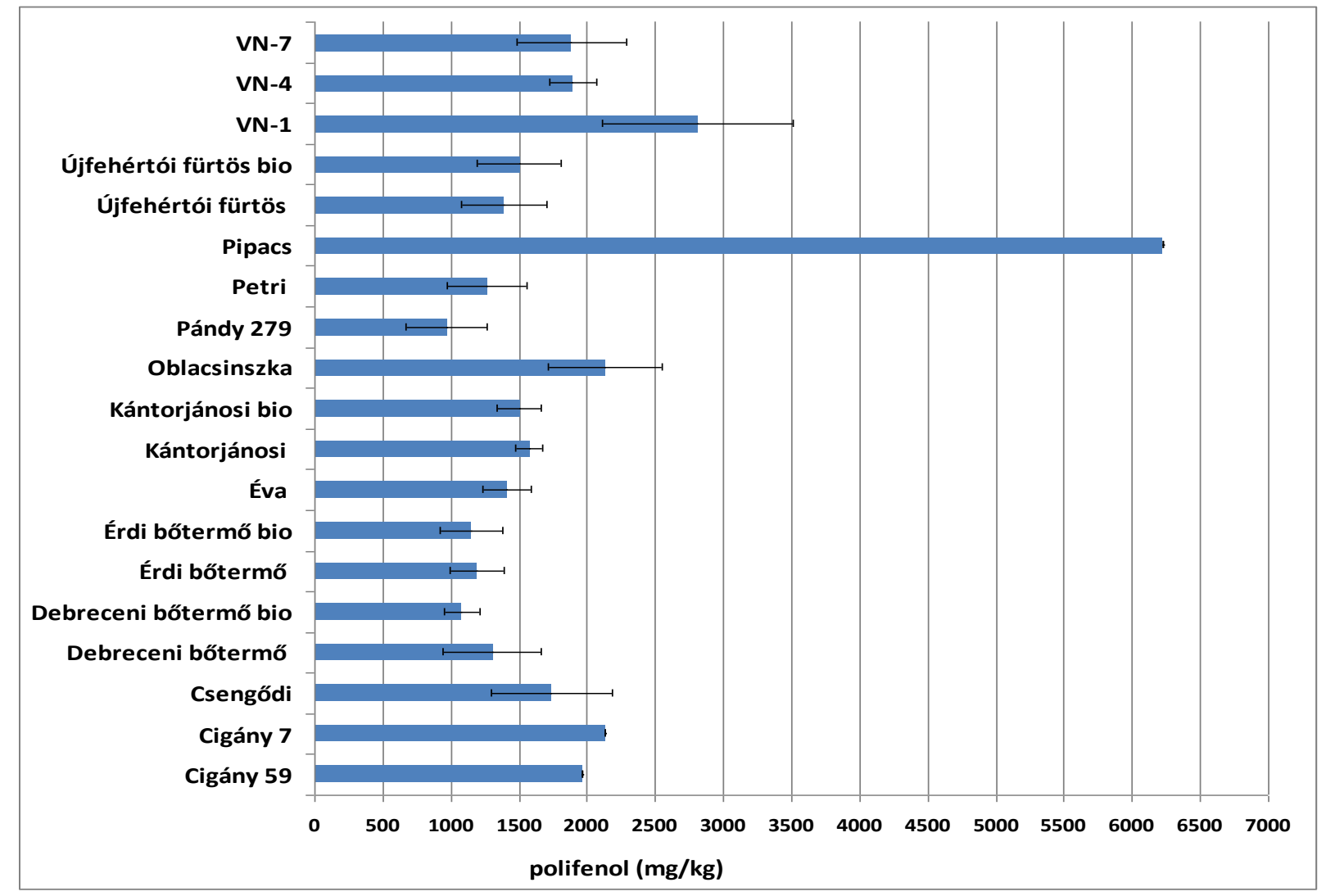

61. ábra: meggy minták átlagos polifenol tartalma az integrált termesztésű fajtáknál

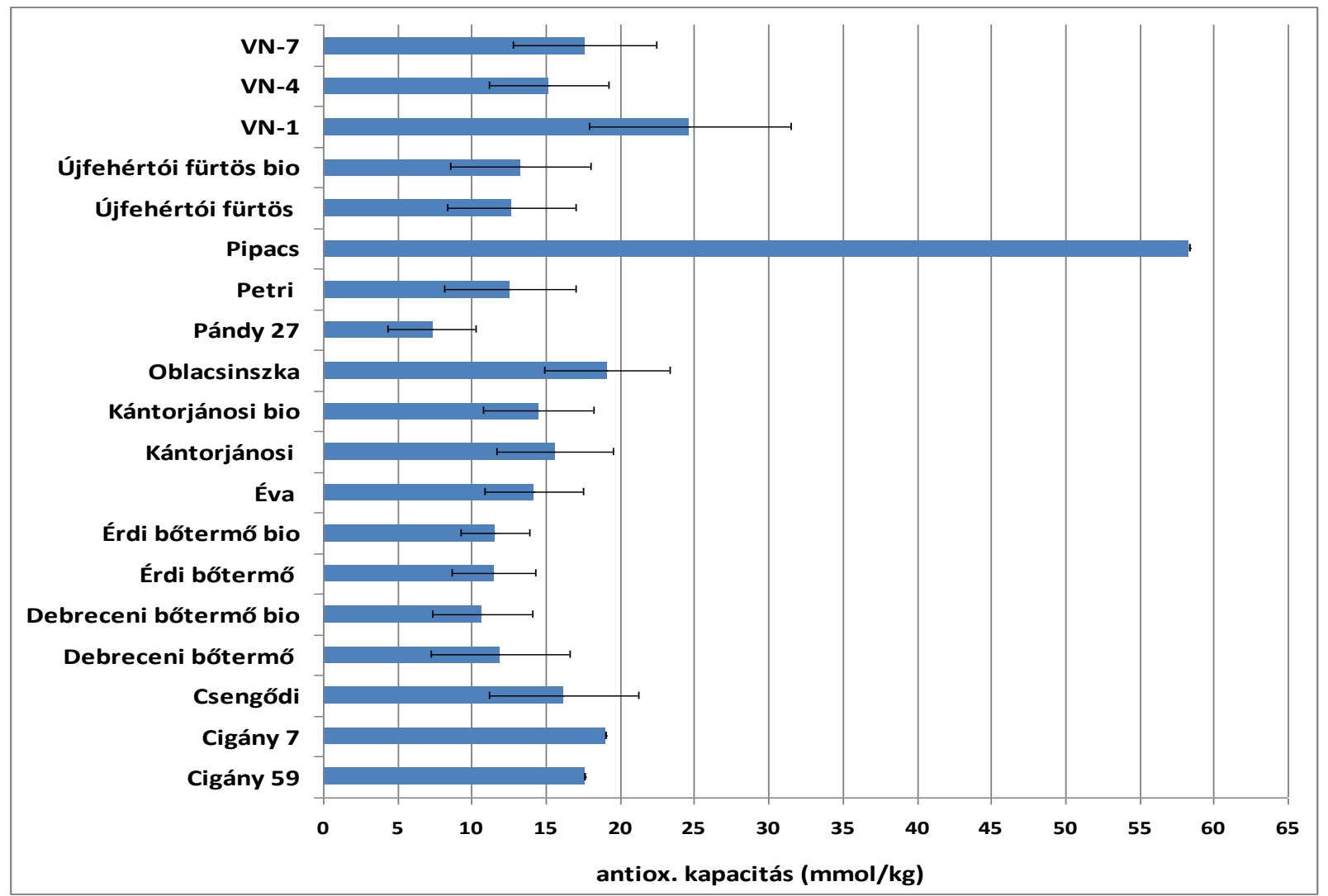

62. ábra: meggy minták átlagos antioxidáns kapacitása az integrált termesztésü fajtáknál 


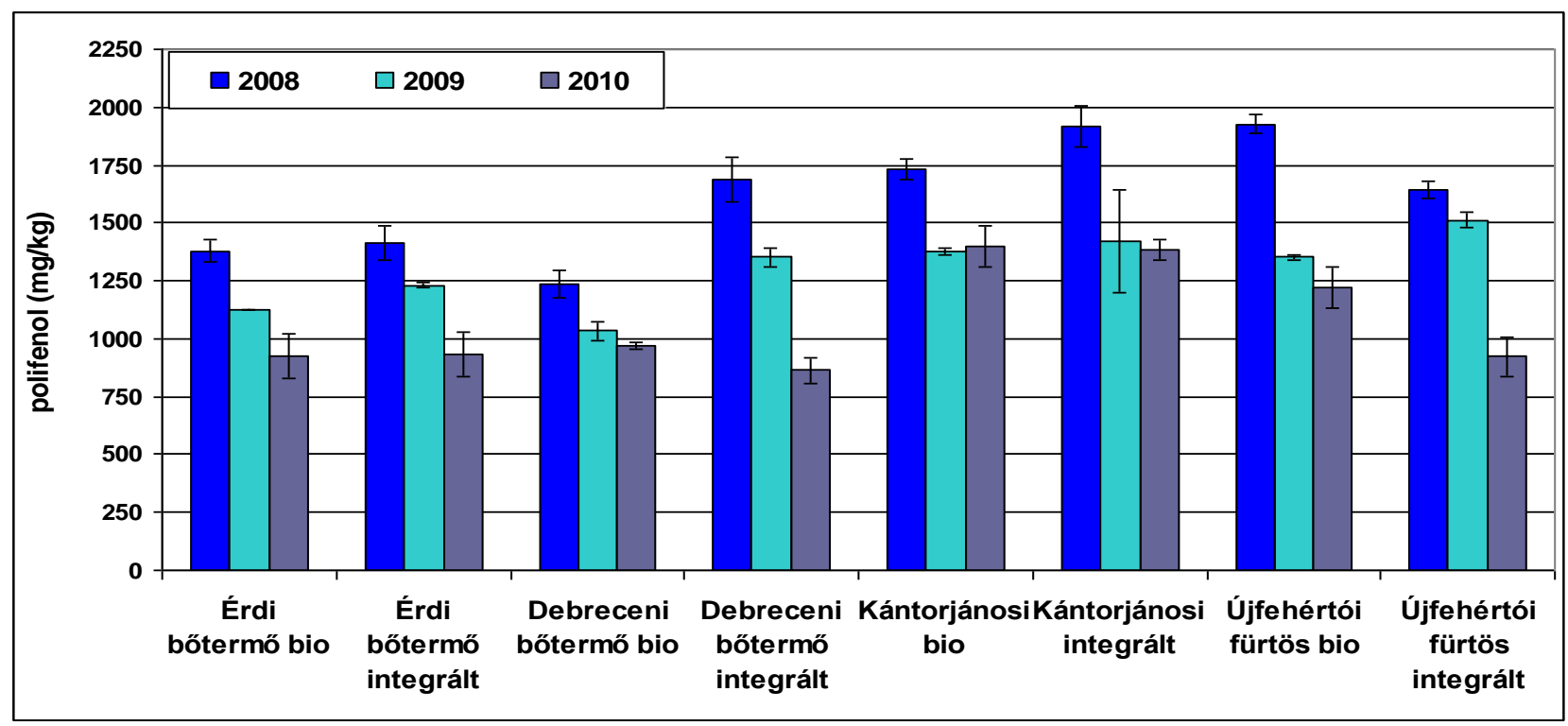

63. ábra: Meggy minták polifenol tartalma a bio és integrált pároknál a három évjáratban

Az évjárat hatása kiemelkedő az egyes minták polifenol illetve antioxidáns kapacitására (65.66. ábra). A meggytermesztés szempontjából kedvezőbb időjárású években - főleg 2008-ban az integrált termesztésű mintákban magasabb polifenol és antioxidáns kapacitás mérhető (63. és. 65. ábra). A 2008 és 2009-es évben a polifenol-tartalom és antioxidáns kapacitás értékekek szignifikánsan $(\mathrm{p}<0,05)$ magasabbak, mint a 2010-es évben. Valószínűsíthető, hogy a termesztési mód és időjárás hatása együttesen befolyásolja a meggy beltartalmi értékeit. Az egyes fajtákra jellemző komponens arányok kisebb ingadozások mellett - mely az évjárat hatásának tulajdonítható - gyakorlatilag állandónak tekinthetők. Az évjárat hatását figyelembe véve, az összefüggéseket leíró korrelációs koefficiens $(\mathrm{r}=0,9416)$ szintén szoros kapcsolatot jellemez (64. ábra).

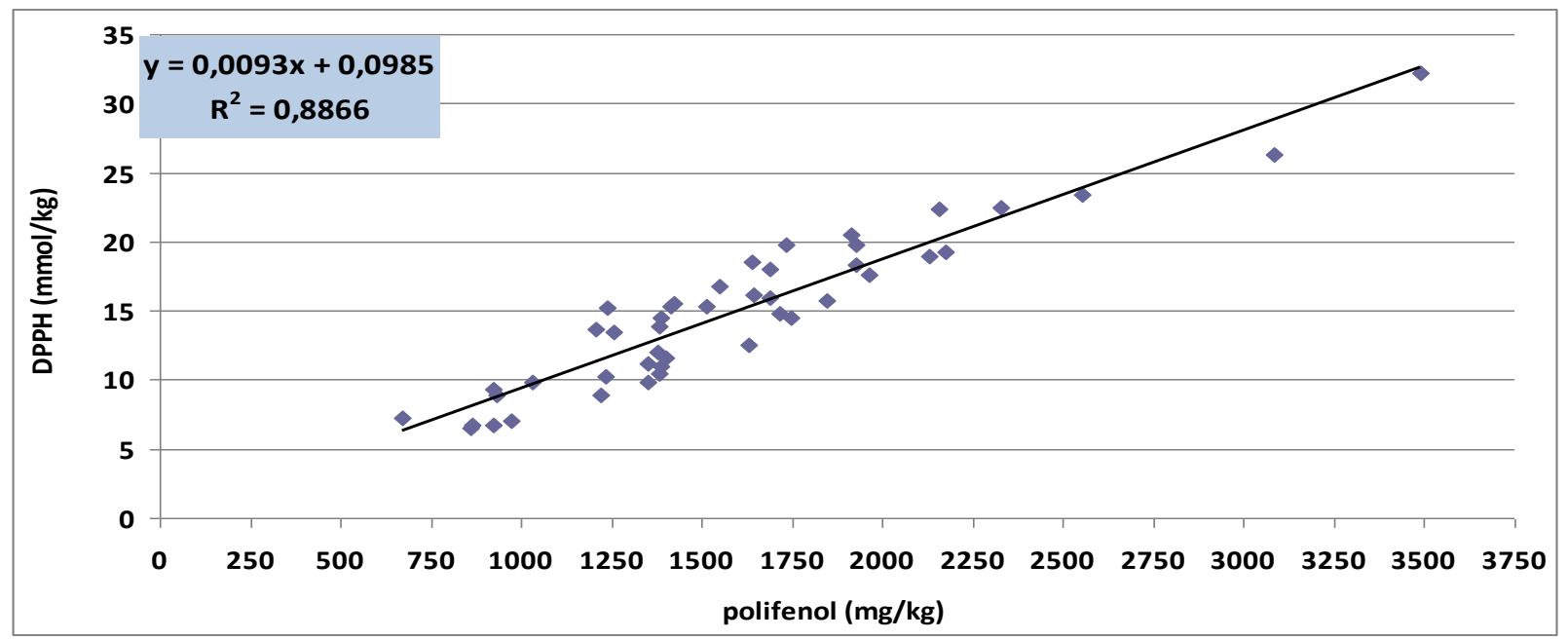

64. ábra: Antioxidáns kapacitás és polifenol tartalom korrelációja a háromévi mérési adatokból 


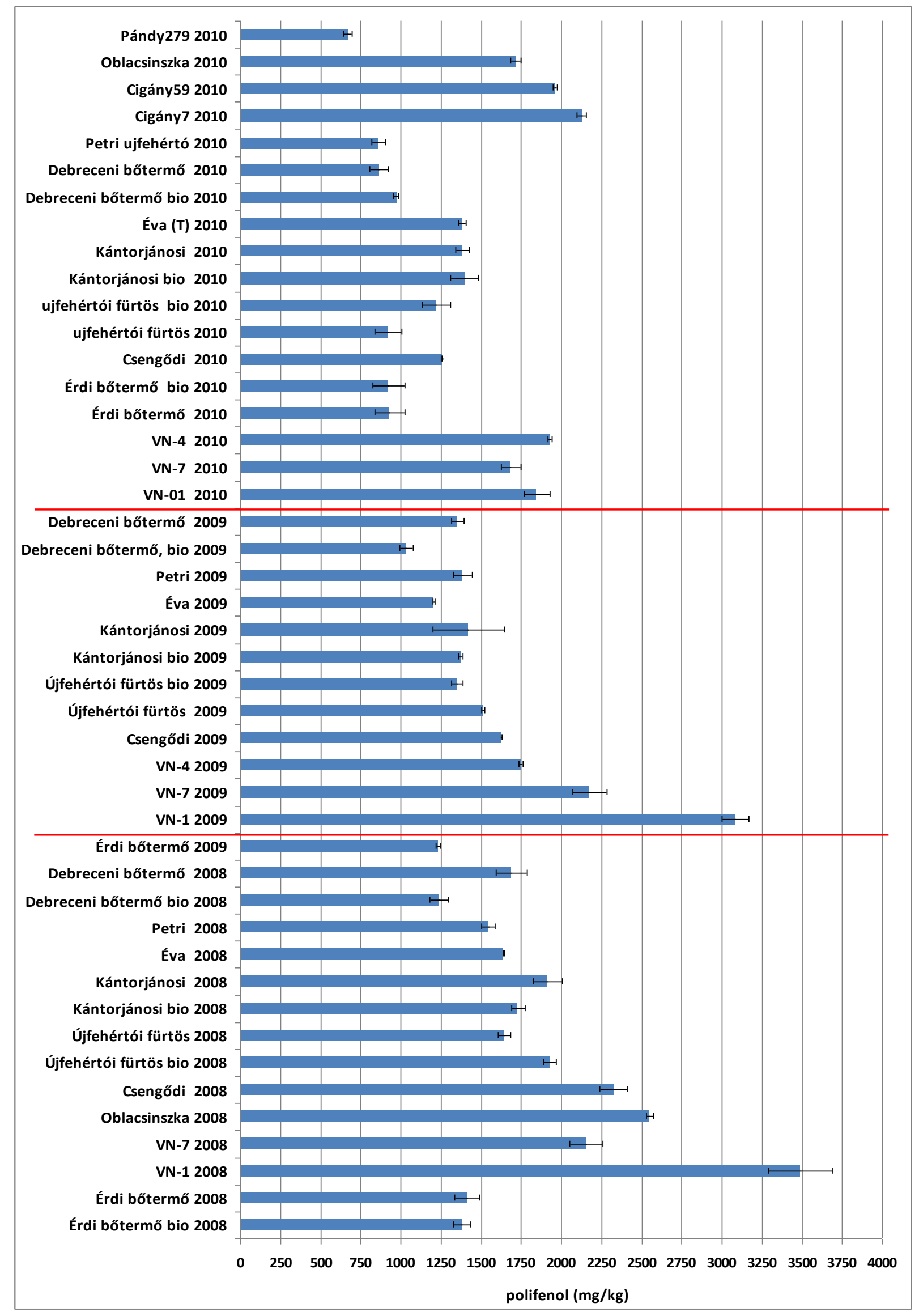

65. ábra: meggy minták polifenol tartalma évjáratonként 


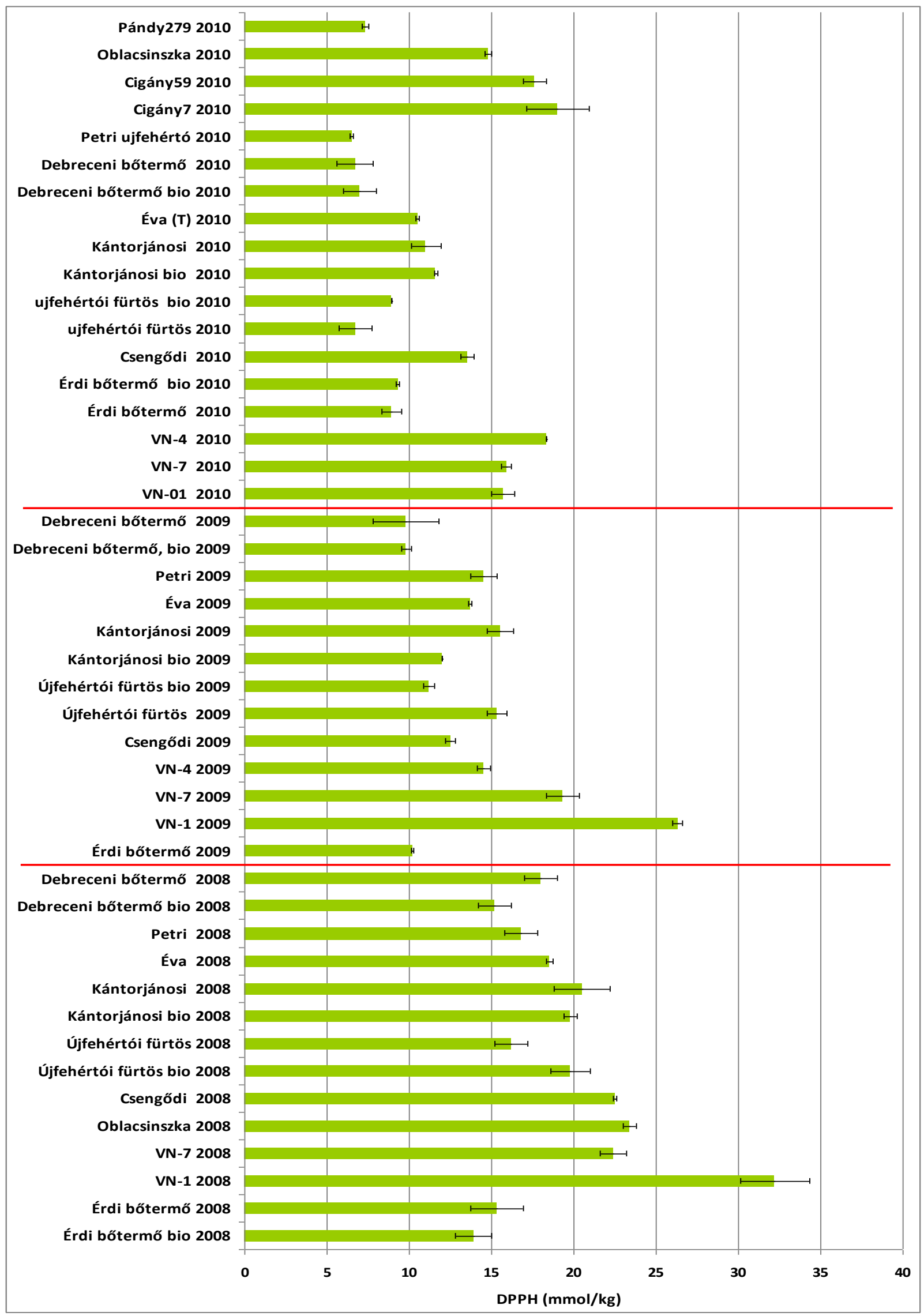

66. ábra: meggy minták antioxidáns kapacitása évjáratonként 
Hierarchikus klaszter analízissel (67. ábra) összesen hat csoportra lehetett elkülöníteni az egyes meggyfajtákat polifenol-tartalom és antioxidáns kapacitás alapján. A 'Pipacs' fajtának kékkel jelölt) rendkívül kiemelkedő a polifenol tartalma $(6230 \mathrm{mg} / \mathrm{kg}$ GAE) és antioxidáns kapacitása. Megjegyezve, hogy szintén nagyon magasa a sav-és szárazanyag-tartalma $(21,3 \mathrm{~g} / \mathrm{kg}$, illetve 20,2\%), ezért rendkívül kedvezőtlen érzékszervi tulajdonságokkal rendelkezik. A második csoportot a 'VN-1' fajta meggy (pirossal jelölt) alkotja, mely a 'Pipacs'-hoz képest közel harmad annyi (2807 mg/kg GAE), viszont még mindig magasabb, polifenol tartalommal és antioxidáns kapacitással rendelkezik, és a 'Pipacs'-al ellentétben frissen is fogyasztható. A következő két csoport (barnával és zölddel jelölt) szintén magas értékekkel rendelkezik. Ide a 'Cigány' megyek (2128 mg/kg, és 1962 mg/kg GAE), 'Oblacsinszka' (2183 mg/kg GAE), 'VN' klón Bosnyák megyek (1883 mg/kg és $1774 \mathrm{mg} / \mathrm{kg}$ GAE) tartoznak. Habár a statisztikai elemzés ide sorolja, de kicsivel alacsonyabb értékkel rendelkező 'Csengődi' meggy (1736 mg/kg GAE), már közelít a következő csoporthoz, melyek (feketével jelölve) a 'Kántorjánosi 3', 'Debreceni bötermö', 'Érdi bötermö', 'Újfehértói fürtös', 'Éva' és 'Petri' fajták. Legalacsonyabb a savtartalma a 'Pándy' klón meggynek (669 mg/kg GAE).

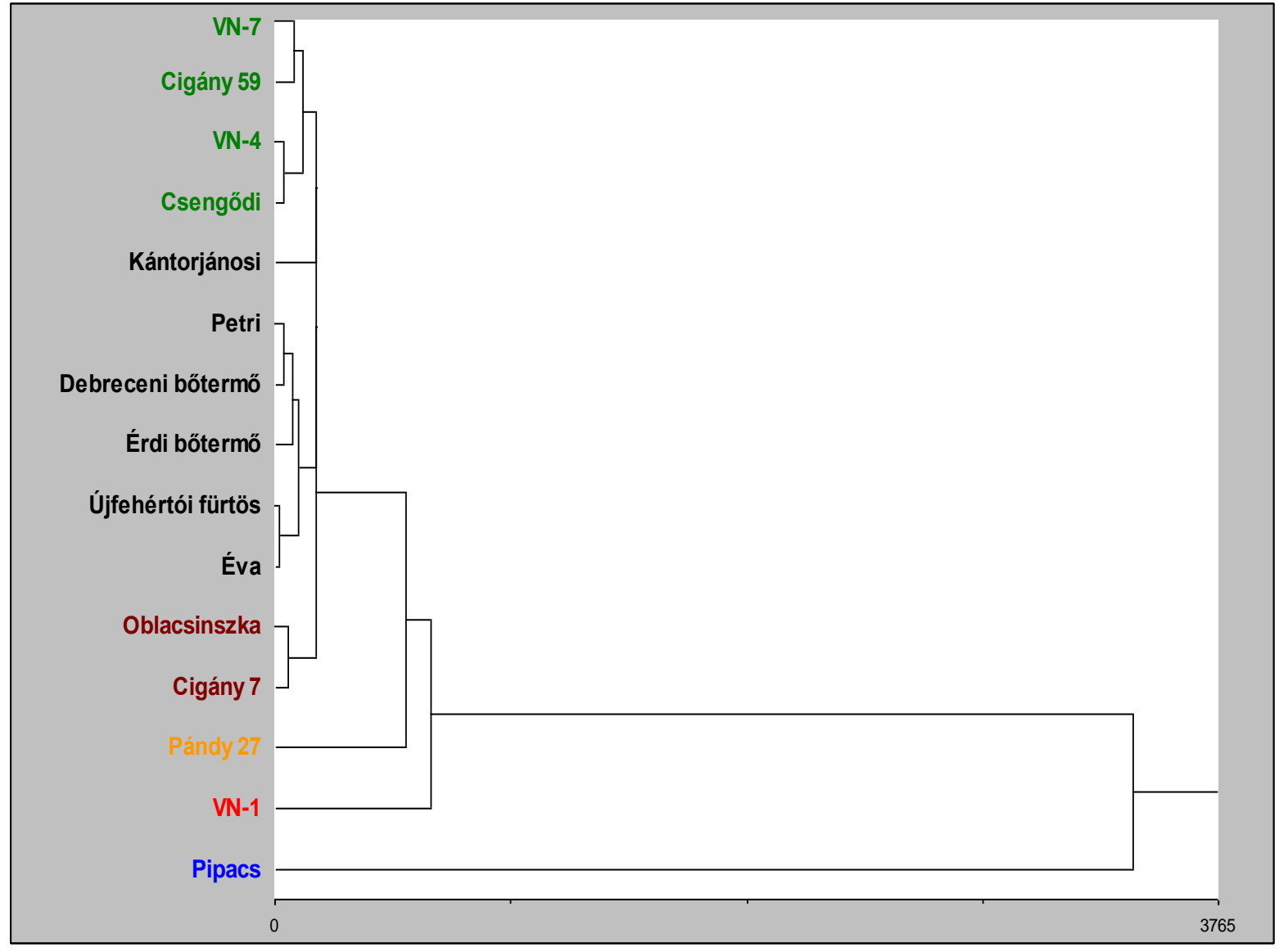

67. ábra: vizsgált meggyfajták csoportosítása hierarchikus klaszteranalízissel polifenol tartalom és DPPH alapján 
A tárolás polifenol-tartalomra kifejtett hatását ötfajta meggy ('Érdi bőtermö', 'Újfehértói fürtös', 'Kántorjánosi 3', 'Éva', 'Petri', 'Debreceni bötermö') esetén a 13. táblázat és 68. ábra mutatja. A vizsgálat az integrált termesztésű mintákra terjedt ki. Négy hét tárolás után a tárolt minták polifenol tartalma minden esetben szignifikánsan $(\mathrm{p}<0,05)$ kisebb volt, mint a frissen szedett mintáké. A 'Petri' és az 'Éva' fajta esetében mindössze 2\%-os az eltérés a friss és a tárolt minták polifenol tartalma között. A 'Debreceni bötermö' és 'Érdi bőtermö' esetében 10\%, míg az 'Újfehértói fürtös' és 'Kántorjánosi 3 ', esetében a különbség már 40\% és 33\%.

\section{3. táblázat: Tárolás hatása a polifenol tartalomra}

\begin{tabular}{|lcr|}
\hline & frissen szedett $(\boldsymbol{m g} / \mathbf{k g}$ & \\
2008-as minták polifenol tartalma & tárolt $(\mathbf{m g} / \mathbf{k g} \mathbf{G A E})$ \\
\hline Érdi bőtermő & 1513 & 1354 \\
Újfehértói fürtös & 1645 & 1030 \\
'Kántorjánosi 3' & 1915 & 1269 \\
Éva & 1639 & 1614 \\
Petri & 1548 & 1535 \\
Debreceni bőtermő & 1689 & 1550 \\
\hline
\end{tabular}

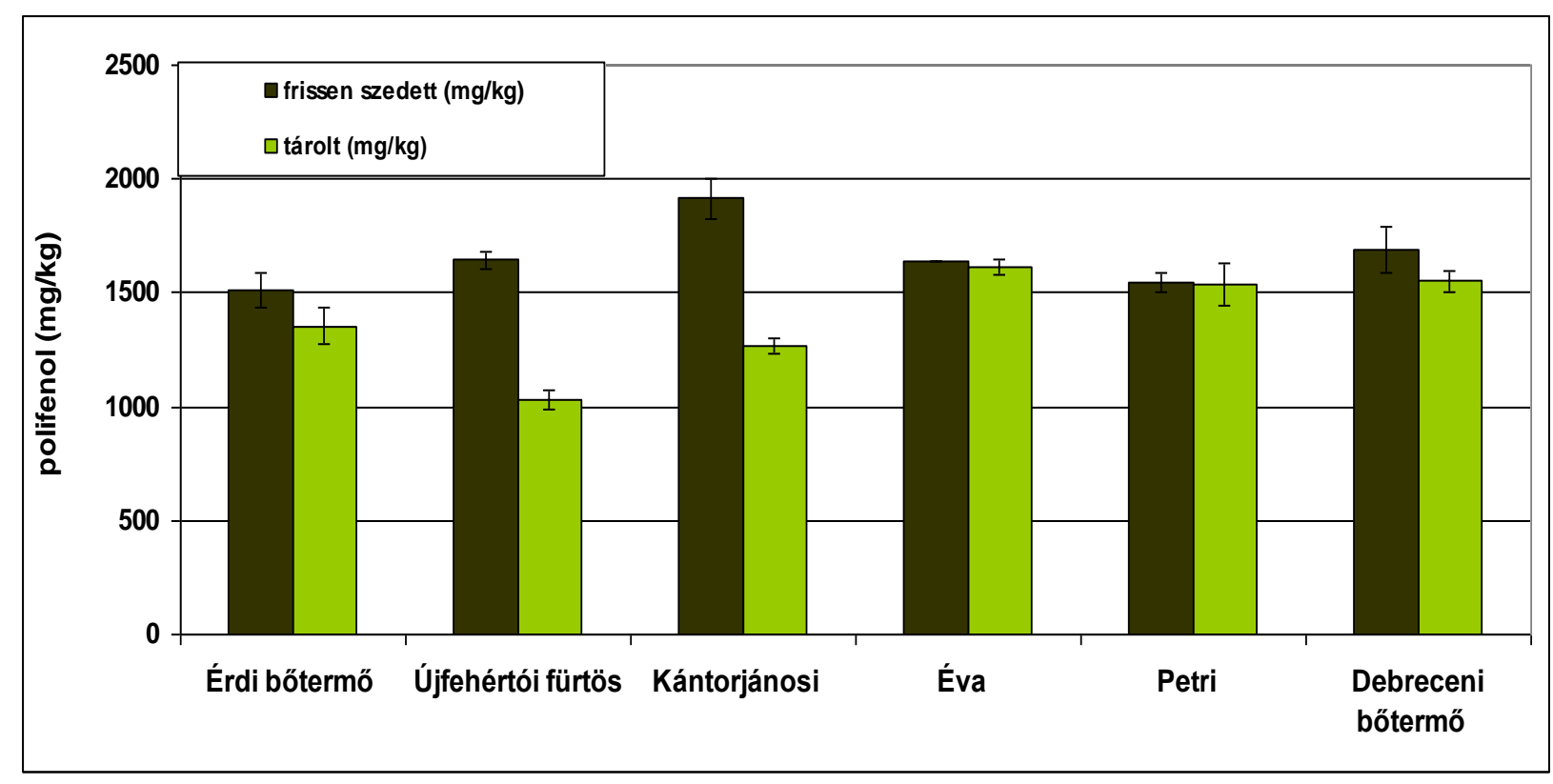

68. ábra: Tárolt és frissen szedett meggy minták polifenol tartalma integrált termesztésü fajtáknál (mg/kg GAE) 


\subsubsection{Cseresznye biológiailag aktív vegyületei}

A mért eredmények alapján a 'Firm red' fajta rendelkezik a legmagasabb polifenol tartalommal és ezzel arányosan antioxidáns kapacitással (69.-70.ábra). Az egyes fajtákra jellemző komponens arányok kisebb ingadozások mellett - mely az évjárat hatásának tulajdonítható gyakorlatilag állandónak tekinthetők. Az évjárat hatását figyelembe véve az összefüggéseket leíró korrelációs koefficiens (r=0,91) szintén szoros kapcsolatot jellemez (71. ábra)

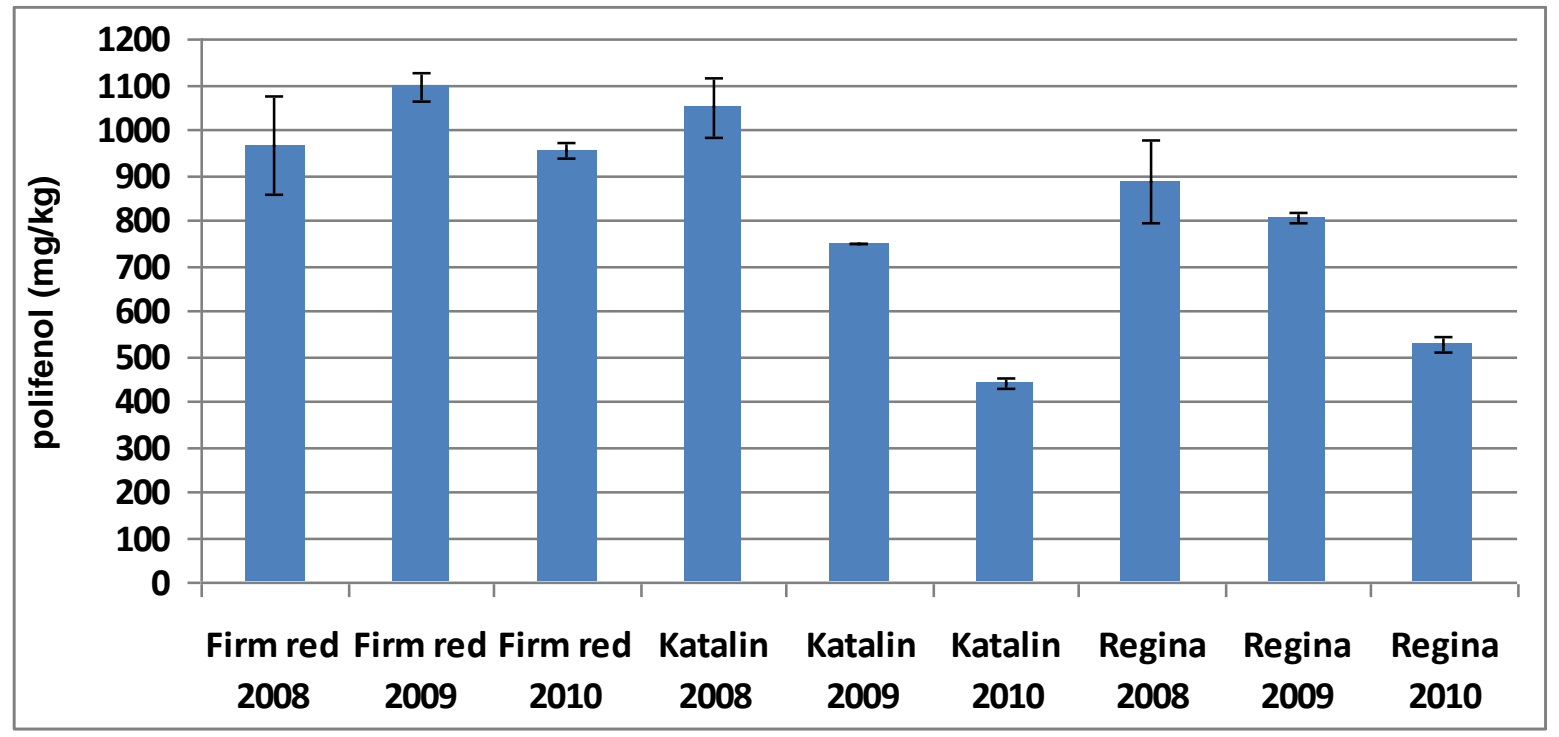

69. ábra: cseresznye minták polifenol tartalma évjáratonként

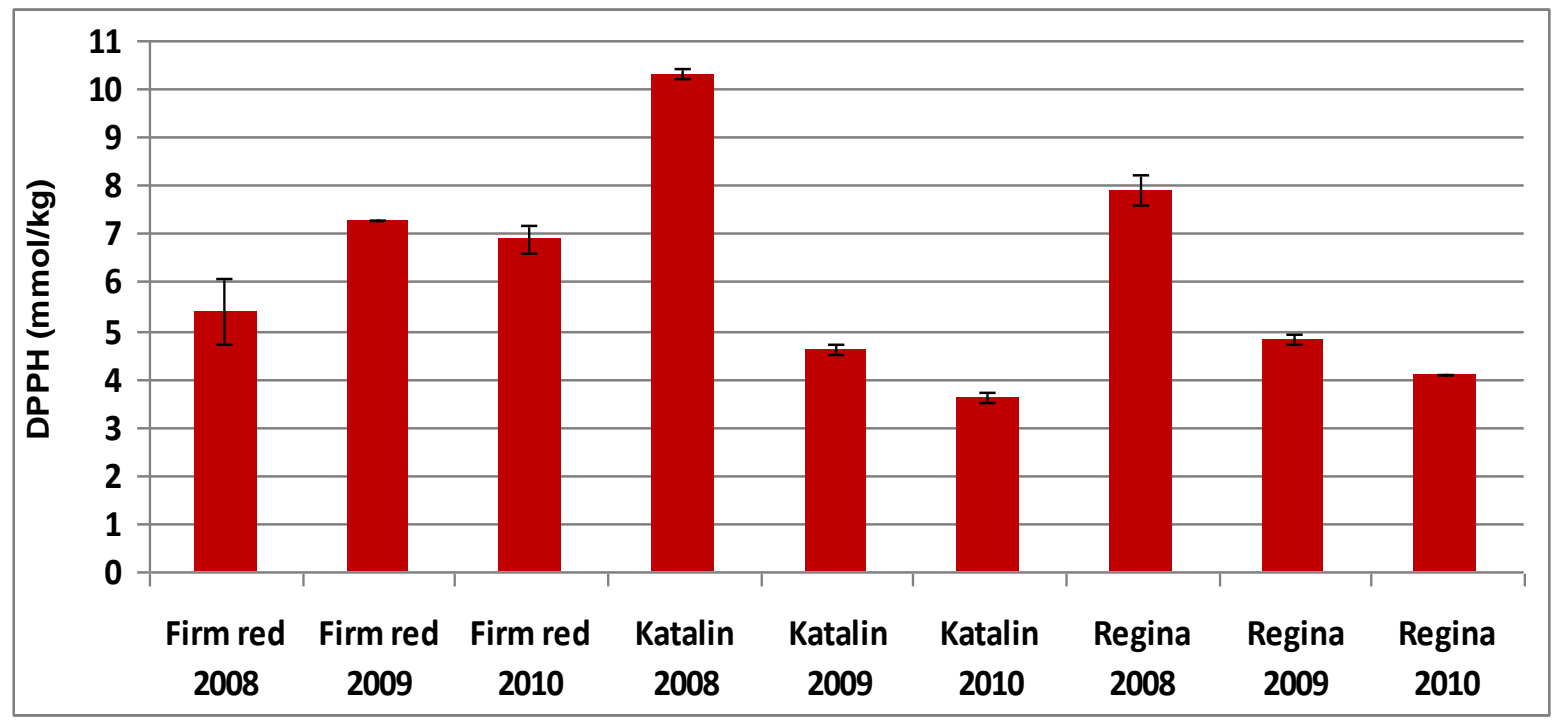

70. ábra: cseresznye minták antioxidáns kapacitása évjáratonként 


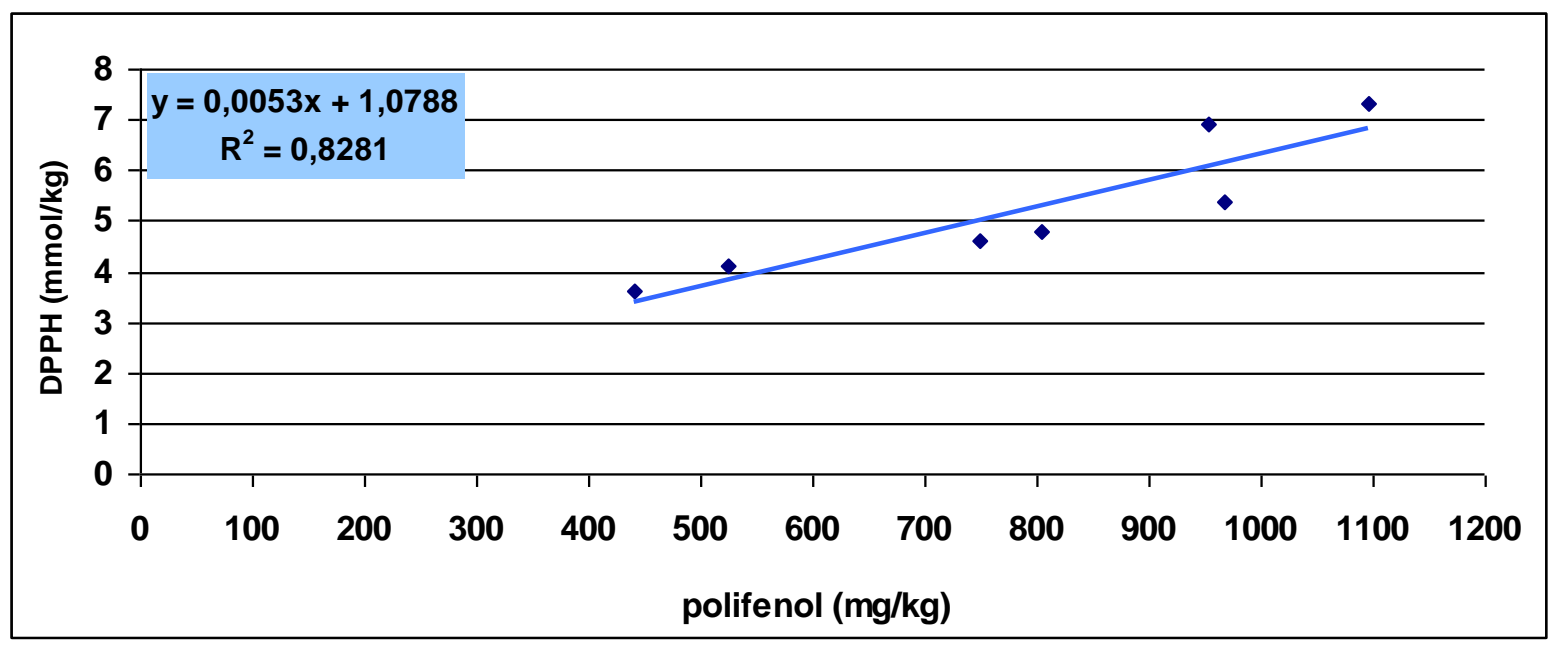

71. ábra: Antioxidáns kapacitás és polifenol tartalom korrelációja a háromévi mérési adatokból

A csonthéjas gyümölcsök polifenol tartalmának áttekintésére a gyakorisági diagrammokon (72. ábra) ábrázoltam az integrált minták paramétereit. A meggyek polifenol tartalma kiemelkedően magas a Tóth-Márkus és munkatársai (2010) által vizsgált alma (500-800mg/kg közötti) és körte (200-800mg/kg közötti) polifenol értékeihez képest. A legalacsonyabb érték (egy kivételével) is $1100 \mathrm{mg} / \mathrm{kg}$ GAE polifenol tartalom, azonban a minták zöme az 1300-1700 $\mathrm{mg} / \mathrm{kg}(27 \%)$, illetve a $2100 \mathrm{mg} / \mathrm{kg}(13,4 \%)$ tartományban helyezkedik el. A magas értékek nagyban hozzájárulnak a meggy, kedvező egészségvédő hatásához. A cseresznye fajták közül a 'Katalin' és 'Regina' fajta polifenol tartalma (700 mg/kg) hasonlít az almára jellemző polifenol értékre, míg a 'Firm Red' fajta inkább a meggyhez (1000 mg/kg).

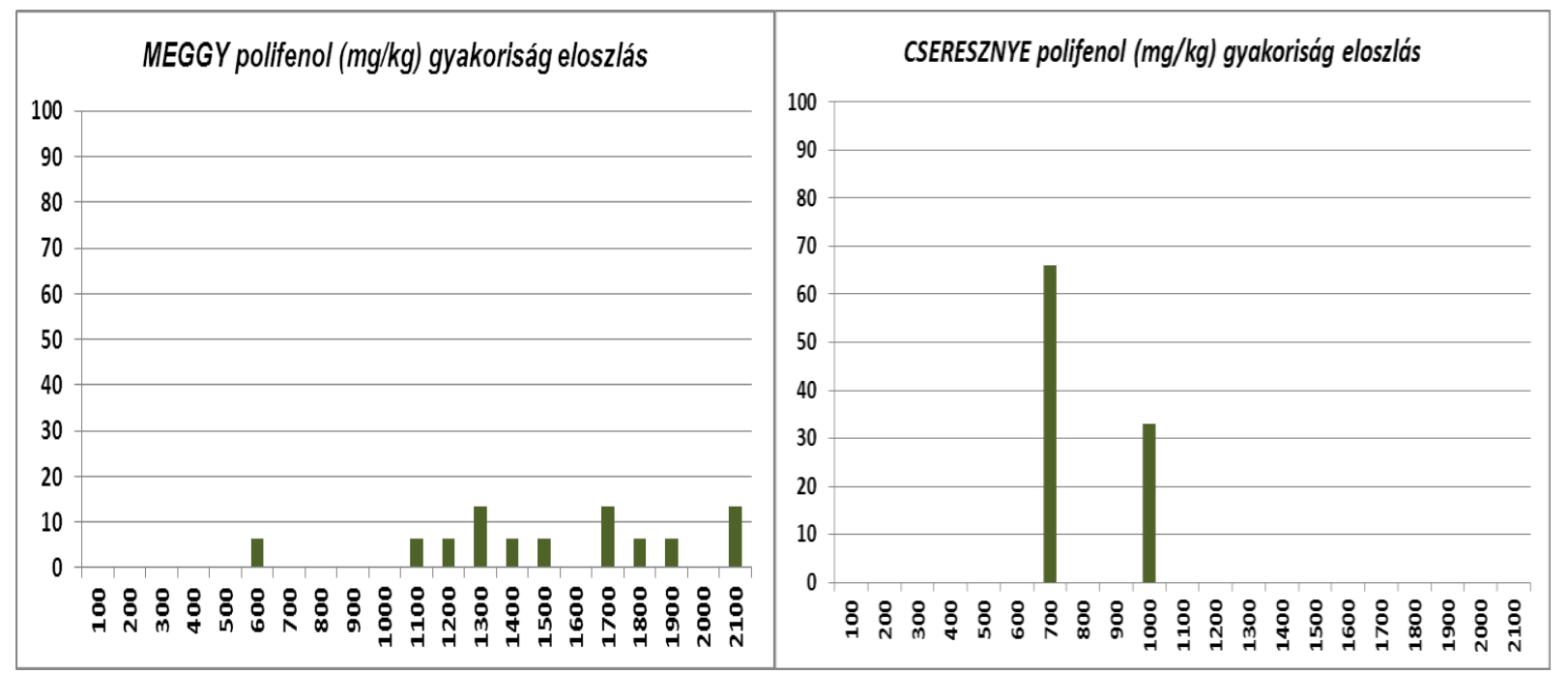

72. ábra: A vizsgált gyümölcsök polifenol tartalma 


\section{Meggy és cseresznye antocianin vegyületeinek vizsgálata}

A 2009-es évben az antocianinok összes mennyisége a cseresznye fajtákban 45-68\%-kal nagyobb volt, mint a 2008-as évben. A meggyeknél egy-két fajtától eltekintve nem volt lényeges változás az összes antocianin tartalomban a két évjárat vonatkozásában. A 'Csengödi' fajtában az összes antocianin tartalom jelentősen 56 \%-kal csökkent 2009-ben a 2008-as évhez viszonyítva, míg az 'Újfehértói fürtös' és a 'Debreceni bötermö' összes antocianin tartalma 31\%-kal és $64 \%$-kal növekedett a 2009-es évben. A 2009-es év adatait a 15. táblázat tartalmazza (M2.-10-11 táblázat).

A bio, ill. az integrált termesztési eljárásokból származó meggymintákat összehasonlítva (M210. táblázat), az eredmények azt mutatták, hogy a Nyíregyházáról származó bio-gyümölcsök összes antocianin tartalma kismértékben magasabb volt az integrált termesztésből származókénál a 2009-es évben is. Kivétel a 'Debreceni bőtermö', amelyben nem volt gyakorlatilag különbség a két termesztési mód között ebben az évben. Az összetételi adatokat figyelembe véve a komponens arányok kisebb ingadozások mellett gyakorlatilag állandónak tekinthetők.

A fenolsavak vonatkozásában a bio és integrált termesztési módok között nincs szignifikáns ( $\mathrm{p}<0,05)$ különbség (M2-11.táblázat)

A cseresznye minták antocianin vegyületeit az 14. táblázat tartalmazza. A minták vizsgálatakor felmerült a meggy és cseresznye minták polifenol vegyületeinek összehasonlítása. Mivel a cseresznyéből csak integrált termesztésű minták álltak rendelkezésre, ezért összehasonlítása csak az integrált termesztésü meggyekével történhetett (15. táblázat).

\section{4. táblázat: Cseresznye fajták antocianin összetétele és mennyisége $\left(\mathrm{mg} \mathrm{kg}^{-1}\right)$}

\begin{tabular}{lllllll} 
& Firm red & \multicolumn{3}{c}{ Katalin } & \multicolumn{3}{c}{ Regina } \\
cy-glu-rut & 1,1 & $\pm 0,5$ & 1,0 & $\pm 0,5$ & 1,0 & $\pm 0,5$ \\
cy-glu & 42,6 & $\pm 10,8$ & 43,8 & $\pm 7,6$ & 10,1 & $\pm 2,3$ \\
cy-rut & 174,0 & $\pm 45,5$ & 364,7 & $\pm 81,7$ & 170,0 & $\pm 29,4$ \\
rutinozid & 2,3 & $\pm 0,7$ & 3,6 & $\pm 1,0$ & 1,9 & $\pm 0,5$ \\
ismeretlen7 & 21,5 & $\pm 4,9$ & 14,0 & $\pm 2,2$ & 6,6 & $\pm 1,1$ \\
ismeretlen6 & 2,3 & $\pm 0,8$ & 2,8 & $\pm 0,2$ & 1,5 & $\pm 0,1$ \\
összesen & 243,0 & $\pm 60,1$ & 428,8 & $\pm 91,8$ & 190,2 & $\pm 31,2$
\end{tabular}

Rövidítések: cy-glu-rut: Cianidin-glukozil-rutinosid, cy-glu: Cianidin-glukozid, cy-glu: Cianidin- rutinozid 
15. táblázat: Integrált termelésböl származó meggyfajtákban az antocianin összetétele és $\underline{\text { mennyisége }\left(\mathrm{mgkg}^{-1}\right)}$

\begin{tabular}{|c|c|c|c|c|c|c|}
\hline \multirow{2}{*}{$\begin{array}{c}\text { Fajta } \\
\text { Szüretelés } \\
\text { dátuma }\end{array}$} & \multirow{2}{*}{$\begin{array}{c}\text { VN-1 } \\
\text { 2009.06.08. }\end{array}$} & \multirow{2}{*}{$\begin{array}{c}\text { VN-7 } \\
2009.06 .15 .\end{array}$} & \multirow{2}{*}{$\begin{array}{c}\text { VN-4 } \\
2009.06 .15\end{array}$} & \multirow{2}{*}{$\begin{array}{c}\text { Újfehértói } \\
\text { fürtös } \\
2009.07 .06 \text {. }\end{array}$} & \multirow{2}{*}{$\begin{array}{l}\text { Csengődi } \\
2009.06 .15\end{array}$} & \multirow{2}{*}{$\begin{array}{c}\text { 'Kántorjánosi } \\
\text { 3' } \\
\text { 2009.07.06. }\end{array}$} \\
\hline & & & & & & \\
\hline cy-glu-rut & $1136,8 \pm 117,6$ & $883,5 \pm 76,4$ & $30,5 \pm 0,4$ & $327,6 \pm 35,7$ & $19,4 \pm 3,1$ & $203,0 \pm 1,2$ \\
\hline cy-glu & $123,5 \pm 12,0$ & $90,5 \pm 7,9$ & $\overline{29,8} \pm 0,3$ & $16,8 \pm 2,1$ & $\overline{21,2} \pm 3,8$ & $11,0 \pm 0,2$ \\
\hline cy-rut & $412,8 \pm 65,2$ & $398,9 \pm 27,2$ & $490,5 \pm 7,4$ & $186,9 \pm 64,9$ & $469,8 \pm 48,2$ & $79,5 \pm 86,0$ \\
\hline pe-rut & $5,6 \pm 0,2$ & $6,2 \pm 0,1$ & $\overline{0,5} \pm 0,5$ & $3,6 \pm 0,1$ & $\overline{0,2} \pm 0,2$ & $2,5 \pm 0,0$ \\
\hline Ism5 & $3,5 \pm 0,6$ & $2,6 \pm 0,6$ & $1,9 \pm 0,3$ & $18,0 \pm 1,9$ & $1,7 \pm 0,1$ & $16,8 \pm 0,9$ \\
\hline Ism6 & $2,4 \pm 0,3$ & $1,7 \pm 0,3$ & $3,2 \pm 0,7$ & $2,0 \pm 0,1$ & $2,7 \pm 0,1$ & $1,2 \pm 0,0$ \\
\hline Ism7 & $\overline{3,1} \pm 0,2$ & $\overline{3,5} \pm 0,2$ & $7,4 \pm 0,4$ & & $7,8 \pm 0,8$ & \\
\hline $\begin{array}{c}\text { Total } \\
\text { anthocianin }\end{array}$ & $1687,8 \pm 194,7$ & $1386,9 \pm 109,2$ & $593,0 \pm 53,3$ & $554,8 \pm 64,9$ & $552,0 \pm 37,7$ & $349,4 \pm 5,6$ \\
\hline
\end{tabular}

\begin{tabular}{|c|c|c|c|c|c|c|}
\hline $\begin{array}{c}\text { Fajta } \\
\text { Szüretelés } \\
\text { dátuma }\end{array}$ & 2009.07.06. & 2009.07.06. & 2009.07.06. & Érdi bőtermő & $\begin{array}{c}\text { D } \\
2009.07 .06 \text {. }\end{array}$ & $\begin{array}{c}\begin{array}{c}\text { Debreceni } \\
\text { bőtermő } \\
2009.07 .06 .\end{array}\end{array}$ \\
\hline cy-glu-rut & $186,9 \pm 16,0$ & $173,8 \pm 16,0$ & $130,3 \pm 18,0$ & $172,3 \pm 35,3$ & $129,2 \pm 7,6$ & $134,9 \pm 15,6$ \\
\hline cy-glu & $9,1 \pm 1,6$ & $8,3 \pm 1,4$ & $6,5 \pm 0,8$ & $12,1 \pm 2,2$ & $7,5 \pm 0,4$ & $6,5 \pm 1,2$ \\
\hline cy-rut & $107,5 \pm 23,8$ & $79,5 \pm 86,0$ & $\overline{79,5} \pm 86,0$ & $63,7 \pm 9,9$ & $79,5 \pm 86,0$ & $69,9 \pm 18,07$ \\
\hline pe-rut & $\overline{1,6} \pm 1,4$ & $\overline{2,3} \pm 0,2$ & $\overline{29,4} \pm 46,5$ & $\overline{2,1} \pm 0,2$ & $\overline{1,4} \pm 0,0$ & $\overline{2,8} \pm 0,4$ \\
\hline Ism5 & $17,6 \pm 3,4$ & $\overline{14,9} \pm 1,4$ & $\overline{14,2} \pm 1,4$ & $0,9 \pm 0,2$ & $13,5 \pm 0,4$ & $8,34 \pm 1,42$ \\
\hline Ism7 & $\overline{0,7} \pm 0,2$ & $\overline{0,9} \pm 0,2$ & $\overline{1,2} \pm 0,2$ & $\overline{1,2} \pm 0,0$ & $\overline{0,9} \pm 0,2$ & $\overline{1,4} \pm 0,2$ \\
\hline \multicolumn{7}{|l|}{ Ism6 } \\
\hline $\begin{array}{c}\text { Total } \\
\text { anthocianin }\end{array}$ & $323,4 \pm 43,4$ & $290,8 \pm 32,7$ & $266,3 \pm 71,9$ & $252,4 \pm 47,4$ & $245,2 \pm 13,1$ & $224,0 \pm 30,2$ \\
\hline
\end{tabular}

Rövidítések: cy-glu-rut: Cianidin-glukozil-rutinosid, cy-glu: Cianidin-glukozid, cy-glu: Cianidin- rutinosid, pe-rut: Peonidin- rutinosid

A táblázatban látható számos hasonlóság az egyes polifenol értékekben. Ennek alátámasztására klaszter analízissel megvizsgáltam a cy-glu-rut, cy-glu, cy-rut, ism 5, ims 7 és ezeknek a komponenseknek a totál polifenol csoportosítását (73. ábra) 


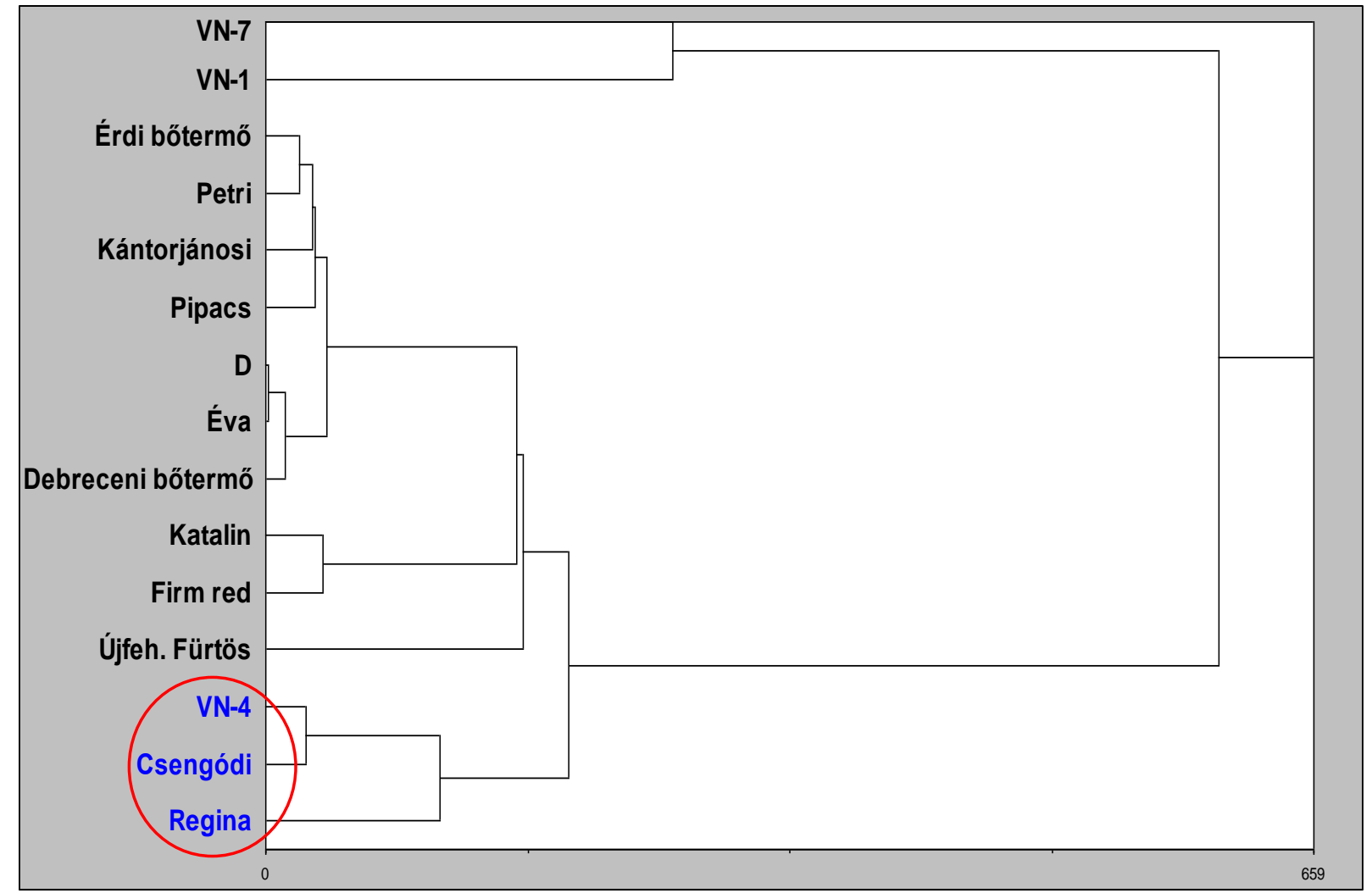

73. ábra: Hierarchikus klaszter analízis a cseresznye és meggy minták polifenol tartalmának összehasonlítására.

A klaszter analízis ábrájából is látszik (kékkel jelölve), hogy a 'Csengődi' és 'VN-4' fajta antocianin összetétele erősen hasonlít a cseresznyék, elsősorban a 'Regina' cseresznye antocianin összetételéhez. További következtetések levonása molekuláris genetikai módszerekkel elvégzett vizsgálatok alkalmazása után lehetséges. Elképzelhető, hogy az antocianin összetételi adatokkal az egyes fajták rokonsági viszonyai nyomon követhetők. Békefi szerint (2005), mivel a cseresznye eredeti hazájában (Skandináv országoktól délre, illetve a vadcseresznye a Kaszpi - és a Fekete-tenger között) elterjedtebb, erőteljesebb és ellenállóbb fajta volt, mint a meggy, ezért valószínübb, hogy a meggy a cseresznyéből származik. Soltész (2005) szerint fejlődéstanilag a cseresznye az idősebb. A meggy feltehetően a diploid Prunis avium és/vagy a tetraploid Prunus fruticosa, P. frutescens kereszteződésével keletkezett. 


\section{4 Új tudományos eredmények}

Külföldi és magyarországi alma, körte, cseresznye és meggyfajták, különös tekintettel az északkelet magyarországi meggyfajták áruértékét meghatározó fizikai paraméterek saját adatokkal való alátámasztása és összegyüjtése három évjáratban és a vizsgálati adatok elemzése. Igazoltam, hogy az ökológiai termesztésü almák gyümölcstömege átlagosan $10 \%$ kal, gyümölcsmérete pedig átlagosan 5\%-kal kisebb.

* Megállapítottam, hogy a beltartalmi összetevőkre (szárazanyag-és savtartalom) alma-és meggyfajták ökológiai és integrált termesztési móddal termesztett fajtáinak összehasonlítása során a fajtatulajdonságok és az évjárat hatása jelentősebb, mint a termesztési módé.

* Az ökológiai és integrált termesztési módot mikrobiológiai szempontból vizsgáltam és elemeztem és alma- és meggyfajták esetében. Igazoltam, hogy az ökológiai és integrált termesztési mód között almafajták és meggyfajták esetében felületi mikrobiológiai szempontból gyakorlatilag nincs különbség.

* Elsőként vizsgáltam Enterobacter sakazakii, Listeria monocytogenes, Salmonella spp. illetve egyéb indikátor mikrobák előfordulását ökológiai és integrált termesztésű alma-és meggyfajták mikrobiológiai összehasonlítására. Megállapítottam, hogy egyetlen esetben sem volt igazolható a fent felsorolt patogén mikrobák jelenléte, egyik gyümölcsfajta, termőhely és termesztési mód esetében sem.

Elsőként vizsgáltam ökológiai és integrált termesztésü meggy antocianin profilját.

* Meggy és cseresznye biológiailag aktív vegyületeinek mérése és az adatok elemzése során alátámasztottam, hogy a polifenol tartalom és antioxidáns kapacitás kialakításában a fajtának döntő szerepe van, a termesztési mód, hely és az évjárat hatásával összehasonlítva. A mért adatoknál is igazoltam a szakirodalomban is leírt polifenol tartalom és antioxidáns kapacitás közötti szoros korrelációt. 


\section{A kutatási eredmények összefoglalása és javaslatok}

Kutatómunkám során négy gyümölcsfajta - alma, körte, meggy és cseresznye - áruértékét befolyásoló tényezőit, felhasználási értéket befolyásoló beltartalmi összetevőit, valamint biológiailag aktív és az egészségmegőrzésben fontos vegyületeit vizsgáltam és a mérési adatok alapján elemeztem három évjáratban (2008-2009-2010). Ebben az átfogó vizsgálatban a fenti paraméterek meghatározásával célom volt az utóbbi években egyre inkább terjedőben lévő és kiteljesedő müvelési formából, az ökológiai gazdálkodásból kikerülő termékek összevetése az integrált termesztésből kikerülő termékekkel, elsősorban a meggy és alma esetében. A vizsgálat 33 fajta alma, 15 fajta meggy, 5 fajta körte és 3 fajta cseresznye bevonásával készült. Az almák egy része a kereskedelemben is kapható rezisztens fajta ('Rewena', 'Remo', 'Resi', 'Releika'), újabban nemesített fajták ('A 8/31' (Soltadino), 'A11/28' (Davidino), 'M5/98 '(Matika), 'AS 10/31'), valamint kereskedelmi fajták ('Gala', 'Jonathan', 'Idared', 'Pinova', 'Pink Lady' stb.), A meggyfajták nagy része az Újfehértói Kutatóközpont észak-magyarországi tájszelekciójával létrejött fajtái (' 'Kántorjánosi 3', ' Debreceni bötermö' stb.) közül került ki, egy része pedig 'Bosnyák' és 'Cigány' megyek. A körték mind kereskedelmi forgalomban ismert fajták ('Vilmos körte', 'Fétel apát', 'Bosc kobak', 'Packham's Triumph', 'Conference'). A cseresznyeminták szintén kereskedelmi forgalomban kapható fajták ('Regina', 'Katalin', 'Firm Red').

A gyümölcsök áruértékét (méret, tömeg) befolyásoló paraméterek vizsgálata során a bio és integrált termesztési módot tekintve az almák esetében találtam különbséget. Az ökológiai termesztésü almák gyümölcstömege átlagosan 10\% -kal, gyümölcsmérete pedig átlagosan 5\% -kal kisebb. Mind a négy vizsgált gyümölcsfaj esetében hierarchikus klaszteranalízissel, illetve grafikonokkal szemléltettem, csoportosítottam az egyes fajtákat. Az almák esetében hat, míg a többi gyümölcsfajnál két csoportot lehetett elkülöníteni a fizikai paraméterek alapján. A meggyek esetében a nagyobb fajtaszám ellenére, csak két csoportot lehetett elkülöníteni, egy kisebb ('Cigány meggyek', 'Oblacsinszka', 'Bosnyák' megyek) és egy nagyobb ('Debreceni bötermö', 'Érdi bőtermö', 'Kántorjánosi 3', 'Éva') méretű és tömegű fajtákból állót. A fizikai paraméterek kialakításában a fajta hatása dominál és kevésbé jelentős a termesztési mód vagy az évjárat hatása.

Élelmiszerbiztonsági szempontból fontos vizsgálati paraméter a gyümölcsök felületi mikrobiális szennyezettsége. A mikrobiológiai vizsgálat során az egyes indikátor mikroorganizmusok jelenlétét (kóliform és E. coli, Pseudomonas aeruginosa, enterobaktériumok), a patogén mikrobákat (Salmonella spp., Listeria spp., Enterobacter sakazakii ), illetve az aerob összcsíraszámot, élesztőés penészgomba határoztam meg. Indikátor mikróbák - azok közül is csak a kóliformok - jelenléte elszórtan volt kimutatható. Pseudomonas aeruginosa felületi szennyezettséget a 2009-es évben 
ökológiai termesztésü alma és integrált meggy esetében - összesen 2 almafajta és 1 fajta meggy találtam. Egyik mintában sem volt kimutatható patogén mikroba a vizsgált mennyiségekben. A rendelkezésre álló aerob összes élőcsíraszám, penész-és élesztőgomba szám alapján értékeltem a különböző gyümölcsök felületi szennyezettségét. Az almánál és a meggynél vizsgáltam az egyes tényezők - fajta, évjárat, termesztési mód - hatását a mikrobiológiai szennyezettség mértékére. Az éjvárat jelentős tényezőnek bizonyult a mikrobiológiai szennyezettség szempontjából. Megfigyelhető, hogy a csapadékosabb és szélsőségesebb 2010-es évben alacsonyabb mikrobaszám volt jellemző. A termesztési módokat vizsgálva is találtam különbséget. Az ökológiai termesztés esetén a magas aerob összcsíraszám és penészszám gyakrabban fordult elő (35.-36. ábra) az alma esetében. A meggynél közel fél nagyságrenddel magasabb mikrobiális szennyezettség tapasztalható (2009-ben a 'Debreceni' és 'Érdi bötermö' esetében eltekintve) az ökológiai termesztésben, de a különbség nem szignifikáns $(\mathrm{p}<0,05)$.

A gyümölcsök sav -és szárazanyag-tartalmának, illetve ezek arányának vizsgálatakor meghatároztam a fajta, termesztési mód és évjárat hatásának szerepét.

A vizsgált gyümölcsök közül a legmagasabb a szárazanyag tartalma a meggynek (átlag 17,25 Brix-fok), ezt követi a cseresznye (átlag 15,7 Brix-fok), majd a körte (14,8 Brix-fok) és az alma (13, 7 Brix-fok). Szabó és munkatársai (2010) szerint azokban az években, amikor magasabb hőingadozás a nappal és éjszaka között megnő a meggy szárazanyag-tartalma is, viszont a túlzott nagy hőmérséklet különbség esetén ez az összefüggés már nem áll fenn. A 2010-es évben a meggy virágzása idején rendkívül szélsőséges időjárás volt, ezért kevés volt az átlaghoz képest a termés. 2010-ben a gyümölcsök későbbi fejlődési fázisaiban is szélsőségesebb volt az időjárás, mint az azt megelőző két évben. Az eltérések ellenére a meggy és cseresznye esetén a különbség nem szignifikáns $(\mathrm{p}<0,05)$ az évjáratot tekintve. Az alma esetében az ökológiai és integrált termesztési mód között nincs szignifikáns $(\mathrm{p}<0,05)$ különbség, viszont az egyes évjáratok közötti különbség megfigyelhető. Az évjáratot figyelembe véve az almánál is jelentős a 2009-es év, kedvező időjárásának hatása (50. ábra). A 2009-es évjáratban mért Brix fok minden fajtánál és termesztési módnál legalább 5\%-kal magasabb, mint a 2010-es szélsőséges és rendkívül csapadékos évben. Az egyes éváratok közötti különbség az alma szárazanyag-tartalmát tekintve szignifikáns ( $\mathrm{p}<0,05)$.

Az egyes gyümölcsfajták évenkénti eredményeit összehasonlítva elmondható, hogy a fajta hatása együttesen dominál az időjárási tényezőkkel a szárazanyag-tartalom értékben. A szárazanyagtartalom szempontjából a termesztési módban nem találtam szignifikáns $(\mathrm{p}<0,05)$ különbségeket. A savtartalmat vizsgálva az egyes fajták között nagyobb a különbség, mint a termesztési módból származó eltérés. A meggyek savtartalma a legmagasabb, átlagosan 18g/kg. Az alma estében az egyes évjáratok között a savtartalmat tekintve szignifikáns $(\mathrm{p}<0,05)$ a különbség. A legmagasabb értékeket - valószínűleg a sok csapadék hatására - 2010-ben mértem. 
Az egyes gyümölcsök egészségvédő szerepéhez nagyban hozzájárulnak a bennük lévő biológiailag aktív anyagok. A meggy és cseresznye esetében meghatároztam az egyes évjáratokból és különbözö termesztési módból származó gyümölcsökben a polifenol-tartalmat és antioxidáns kapacitást. A szakirodalom alapján a fenti két paraméter között szoros szignifikáns $(\mathrm{p}<0,05)$ korrelációt igazoltam az egyes gyümölcsökre. Az adatok alapján néztem a termesztési mód, fajta és évjárat meghatározó szerepét a beltartalmi értékek alakulásában. A két csonthéjas csümölcsnél szignifikánsak a különbségek az évjáratok között a polifenoltartalmat és antioxidáns kapacitását tekintve. Ugyanakkor , az egyes fajtákra jellemző komponens arányok kisebb-nagyobb ingadozások mellett - mely az évjárat hatásának tulajdonítható - gyakorlatilag állandónak tekinthetők. A meggynek kiemelkedően magas a polifenol tartalma (átlag 1100-1900 mg/kg) és ezzel összhangban az antioxidáns kapacitása is. Hierarchikus klaszteranalízissel a meggynél hat csoportot lehetett elkülöníteni.

Az antocianinok a növényi színezékek egy jelentős csoportja. Az antocianinok gyökfogó, kelátképző illetve lipidperoxidációt gátló hatásuk élettani szempontból rendkívül fontos. $\mathrm{Az}$ ökológiai, ill. az integrált termesztési eljárásokból származó meggymintákat összehasonlítva az eredmények azt mutatták, hogy a Nyíregyházáról származó biogyümölcsök összes antocianin tartalma kismértékben magasabb volt az integrált termesztésből származókénál a 2009-es évben. Kivétel a 'Debreceni bötermö', amelyben nem volt különbség a két termesztési mód között ebben az évben. Az összetételi adatokat figyelembe véve megállapítható, hogy a komponens arányok kisebb ingadozások mellett gyakorlatilag állandónak tekinthetők. A fenolsavak vonatkozásában az ökológiai és integrált termesztési módok között nincs szignifikáns $(\mathrm{p}<0,05)$ különbség. A meggy és a cseresznye antocianin profiljának összehasonlítésa után az eredményeket klaszter analízis segítségével elemeztem. A 'Csengődi' és 'VN-4' meggyfajta antocianin összetétele erősen hasonlít a cseresznyék, elsősorban a 'Regina' cseresznye antocianin összetételéhez. Elképzelhető, hogy az antocianin összetételi adatokkal az egyes fajták rokonsági viszonyai nyomon követhető.

\section{További javasolt vizsgálatok}

A kutatás kiegészítéseként érdemes lenne további fajtákkal bővíteni az eddigi vizsgálatokat illetve még több gyümölcsfajtát bevonni a vizsgálatba, különös tekintettel azokra, ahol rendelkezésre áll az ökológiai és integrált művelésből bevonható vizsgálati minta. További értékmérő vizsgálat lehetne tárolási kísérletek elvégzése mindkét termesztési módból származó mintákkal. 


\section{Summary of research results and proposals}

In the course of my present research I examined four types of fruits - apples, pears, sour cherries, sweet cherries (henceforth cherries) - and carried out a comprehensive investigation focusing on the factors affecting the production of goods value the nutritional components and the biologically active compounds in three vintages (2008-2009-2010). In the overall study my aim was - with the determination of the above parameters - the comparison of products primarily for cherries and apples originating from organic and integrated cultivation forms. The organic cultivation is spreading more and more in the recent years. During the research 33 cultivars of apples, 15 cultivars of sour cherries, 5 cultivars of pears and 3 cultivars of cherries were investigated. One part of the apples is the commercially available resistant varieties ('Rewena', 'Remo', 'Resi', 'Releika'), another category is made up of new varieties ('A 8/31' (Soltadino), 'A11/28' (Davidino), 'M5/98' (Matika), 'AS 10/31') and the third involves commercial varieties ('Gala', 'Jonathan', 'Idared', 'Pinova', 'Pink Lady', etc.). Most of the varieties of sour cherries originate from the Újfehértó Research Center of Northern Hungary established by land varieties selection ('Kántorjánosi 3', 'Debrecen bötermö' etc), some varieties are 'Bosnian' sour cherry cultivars and 'Morello' sour cherry. The pears are commercially known varieties ('Williams', 'Abate fetel', 'Bosc kobak', 'Packham's Triumph', 'Conference'). The cherry samples are all commercially available varieties ('Regina', 'Catherine', 'Red Firm').

During the examination of the fruit parameters affecting goods value (size, weight) in terms of organic and integrated production modes, differences were found in apples. The average fruit weight of organic apples is $10 \%$ less and the average fruit size is $5 \%$ less than in case of integrated fruits. Each of the four species was classified and illustrated with a hierarchical cluster analysis and graphs. In case of apples six, as for the other fruits two groups can be separated according to the physical parameters. Concerning sour cherries, despite the large number of varieties, only two groups could be distinguished into a smaller size and weight variety ('Morello', 'Oblacsinszka', 'Bosnian') and a larger ('Debreceni bötermö', 'Érdi bötermö', 'Kántorjánosi 3', 'Éva') size and weight variety. The cultivar has a dominant role in the forming of physical parameters in which the production method and weather play a minor role only.

The microbial contamination of the surface of the fruit is an important test parameter concerning food safety. During the microbiological examination indicator organisms, (coliforms, E. coli, Pseudomonas aeruginosa, enterobacters) pathogenic microbes, (Listeria spp. Enterobacter sakazakii, Salmonella spp.), total aerobic plate count, yeast and mould number were determined. The presence of indicator microbes - mainly coliforms - were sporadically detected. Pseudomonas 
aeruginosa surface contamination was detected in the year of 2009 in apples (2 cultivars) originating from organic growing system and one type of sour cherry (1 cultivar) originating from the integrated growing system. There were not any pathogenic microbes detectable in the samples. The microbial surface contamination was evaluated in case of each fruit (sour cherry, cherry, apple, pear) on the basis of the detected total aerobic microbial count and the total combined yeasts/moulds count. I examined the impact of individual factors - variety, vintage, production methods - on the microbiological contamination in case of apples and sour cherries. Vintage proved to be dominant regarding the microbial contamination. It can be observed that in the wetter and more extreme year of 2010 low microbial count was characteristic. Examining the modes of production a significant $(\mathrm{p}<0,05)$ difference was found. In case of organic farming the high total aerobic microbial count and total combined yeasts/moulds count occurred more frequently (Fig. 3536.) regarding apples. In case of sour cherries originateing from organic farming approximately half orders of magnitude higher microbial contamination is observed (except for 2009 'Debreceni bötermö' and 'Érdi bötermö'), but the difference was not significant ( $<<0,05)$.

The aim during the examination of the fruit acid content and dry-extract content was to define the effect of variety, vintage, cultivation method and the ratio of these factors. Among the investigated fruits the sour cherries (17.25 ${ }^{\circ}$ Brix) have the highest dry-extract content followed by cherries (average $15.7^{\circ}$ Brix), pears $\left(14.8^{\circ}\right.$ Brix) and finally apples (13.7 ${ }^{\circ}$ Brix). According to Szabo et al (2010), in those years, where there is a higher temperature fluctuation between day and night, the dry-extract content of the sour cherry increases, however, this relationship no longer exists in those years where there are excessive high temperature differences. In the year of 2010 during the time of cherry blossom the weather was extremely inclement, which caused fewer crops than the average yield. In 2010 in the later developmental stages of the fruit the weather was more extreme too than in the previous two years. Despite the divergences in the years in case of sour cherries and cherries the difference is not significant $(\mathrm{p}<0,05)$. In case of apples there were no significant $(\mathrm{p}<0,05)$ differences between the organic and the integrated production methods, but the difference between the vintages is observed. The positive benefit of the weather of the year 2009 is significant in apples too (Figure 50). The detected dry-extract content in the year of 2009 was at least $5 \%$ higher in case of every variety and cultivation method than in the extreme and extremely wet year of 2010 . The difference between the apple dry-extract content in each year is significant $(\mathrm{p}<0,05)$.

Comparing the annual results of each fruit variety it may be determined that the weather effects and variety together are dominant factors in the dry-extract content values. The production methods have not effect the dry-extract content. Investigating the acid content the difference is greater between the varieties than the differences from the production mode. The acid content of sour cherries is the highest between the examined fruits, with an average of $18 \mathrm{~g} / \mathrm{kg}$. In case of apples the 
difference in acid-content is significant $(\mathrm{p}<0,05)$ between vintages. The highest acid content values - probably due to the high rainfall - were measured in 2010.

The biologically active substances, which are contained by fruits greatly contribute to their health care impact. The polyphenol content and antioxidant capacity were determined from sour cherries and cherries in each vintage and in each cultivation method. Based on the literature, a tight significant $(\mathrm{p}<0,05)$ correlation was proven between the polyphenol content and the antioxidant capacity in the examined fruits. Based on the measured data the decisive role of vintage, variety and cultivation method in nutritional value was investigated. In case of the two stone fruits significant $(\mathrm{p}<0,05)$ differences were determined between the vintages in terms of polyphenol content and antioxidant capacity. However, certain component ratios are typical of the varieties with smaller and larger fluctuations - attributed to the effect of vintage - practically considered permanent. The sour cherry has extremely high polyphenol content (average from 1100 $1900 \mathrm{mg} / \mathrm{kg}$ ) and antioxidant capacity in accordance. Applying a hierarchical cluster analysis six groups can be distinguished in case of sour cherries.

Anthocyanins are an important group of plant dyes. The most important property is their capacity to act as antioxidants protecting, the body against reactive oxygen species due to their ability to scavenge free radicals. Comparing fruits from organic and integrated production processes, the results showed that the content of total anthocyanins was slightly higher in case of organic fruits from Nyíregyháza than fruits from the integrated cultivation in the year of 2009, except for the 'Debreceni bötermö' variety, where no difference was detected between the two cultivation methods in this year. Taking into account the measured composition data, certain component ratios are

typical

of the varieties with smaller and larger fluctuations, which are practically considered permanent. In relation to phenolic acids non-significant differences were found between the organic and integrated production methods. The anthocyanin profile of sour cherries and cherries were compared and examined using a cluster analysis. The anthocyanin composition of 'Csengödi' and ' $V N-4$ ' closely resembles the anthocyanin composition of cherries, primarily, that of Regina cherries. It is conceivable that the anthocyanin composition data of each type can be applicable for tracing the relationships of each variety.

\section{Recommended further examinations}

In addition to the present research it might be worth expanding the examinations with more fruit species and varieties in the future, particularly with those where there are fruit samples from both organic and integrated - crop productions. Further measuring value studies could be carried out with storage experiments with samples from the two production methods. 


\section{Mellékletek}

\section{M1. Irodalomjegyzék}

Abadias, M., Usuall, J., Anguera, M., Solsona, C. \& Vinas, I. (2008): Microbiological quality of fresh, minimally-processed fruit and vegetables, and sprouts from retail estabilishments. Int. J. Fd. Microbiol., 123, 121-129.

Abdulla, A. \& Badaway, B. (2001): Moderate alcohol consumption as a cardiovascular risk factor: the role of homocycteine and the need to re-explain the 'French Paradox'". Alcohol \& Alcoholism 36 (3): 185-188. doi:10.1093/alcalc/36.3.185

Aberoumand, A. \& Deokule, S.S. (2008): Comparison of Phenolic Compounds of Some Edible Plants of Iran and India. Pakistan Journal of Nutrition 7 (4): 582-585.

Abrankó, L., Dernovics, M., Fodor, M., Gyepes, A., Szatura, Zs., Woller, Á. (2010): Hagyományos, gyors és automatizált módszerek alkalmazása élelmiszerek kémiai vizsgálatára. Nemzeti Tankönyvkiadó, Digitális Tankönyvtár.TAMOP 4.2.5 Book Database.

Amarante, C.V.T., Steffens, C.A., Mafra, A.L., Albuquerque, J.A. (2008): Yield and fruit quality of apple from conventional and organic production systems. Pesq. Agrospec.bras. Brasilia, v. 43, n. 3, 333-340.

Amarowicz, R.; Pegg, R.B.; Rahimi-Moghaddam, P.; Barl, B.; Weil, J.A. (2004): Free-radical scavenging capacity and antioxidant activity of selected plant species from the Canadian prairies. Food Chemistry, 84, , 2004 , p. 551-562(smus, K. D., Bonifacic, M.(2000): Free radical chemistry. In: Sen, C. K., Packer, L. \& Hanninen, O. P. (szerk.): Handbook of Oxidants and Antioxidants in Exercise. Elsevier, Chapter 1. pp. 3-56. .

Asmus, K. D., Bonifacic, M.(2000): Free radical chemistry. In: Sen, C. K., Packer, L., Hanninen, O. P. (szerk.): Handbook of Oxidants and Antioxidants in Exercise. Elsevier, Chapter 1. pp. 3-56.

Aude, E., Tybirk, K.\& Pedersen, M.B., (2003): Vegetation diversity of conventional and organic hedgerows in Denmark. Agric. Ecosyst. Environ. 99, 135-147.

Avery, L.M., Killham, K \& Jones, D.L. (2005): Survival of E.coli O:157:H7 in organic wastes destined for land application. J.appl. Microbiol. 98, 814-822

Balázs, K. (1997): Kertészek növényvédelmi naptára. Mezőgazda Kiadó, Budapest, 383pp.

Balogh, E. (2010): Antioxidáns kapacitás meghatározása és ennek kialakításában szerepet játszó vegyületek vizsgálata bogyós gyümölcsök esetében. Doktori $(\mathrm{PhD})$ értekezés, Budapesti Corvinus Egyetem, Élelmiszertudományi Doktori Iskola.

Baráth Cs. (1996): Biometria. Budapest: Mezőgazda Kiadó,288p.

Batáné Vidács, I., Kovács, E., Korbasz, M. \& Beczner, J. (2005): Bogyós és csonthéjas gyümölcsök felületi mikrobás szennyezettségének vizsgálata (Investigation of the surface 
contamination of berry and stone fruits. -in: HUNGALIMENTARIA 2005, April, 19-20, Budapest. Book of Abstracts., p. 11.

Békefi, Zs. (2005): Cseresznyefajták termékenyülési sajátosságainak vizsgálata hagyományos és molekuláris módszerekkel. Doktori (PhD) értekezés, Budapesti Corvinus Egyetem, Élelmiszertudományi Doktori Iskola.

Beczner, J., Bata-Vidács, I. (2009): Microbiology of plant foods and related aspects. Acta Alimentaria, Vol. 38 (Suppl.), pp. 99-115. doi: 10.1556/AAlim.38.Suppl.7

Beuchat, L.R. \& Ryu, J-H. (1997): Produce handling and processing. Emerg. Inf. Diseases., 3, 459-465.

Beuchat, L.R. (1996): Pathogenic microorganisms associated with fresh produce. J.Fd. Prot., 59, 204-216.

Beuchat, L.R. (2002): Ecological factors influencing survival and growth of human pathogens on raw fruits and vegetables. Microbes Infection, 4, 413-423.

Boller, E. F., Avilla, J., Joerg, E., Malavolta, C., Wijnands, F.G., Esbjerg, P. (Eds.): (2004): Integrated Production, Principles and Technical Guidelines. IOBC, Wädenswil, Switzerland

Boutin, C., Baril, A., Martin, P.A., (2008): Plant diversity in crop fields and woody hedgerows of prganic and conventional farms in contrasting landscapes. Agric. Ecosyst. Environ. 123, $185-193$.

Brand-Williams W., Cuvelier, M:E. and Berset, C. (1995): Use of a Free Radical Method to evaluate antioxidant activity. Lebensm.-Wiss. U.-Technol., 28, 25-30.

Breinholt (1999): Desirable versus harmful levels of intake of flavonoids and phenolic acids. In: J. Kumpulainen and J.E. Salonen, (Eds.) Natural Antioxidants and Anticarcinogens in Nutrition, Health and Diseas. The Royal Society of Chem., Chambridge, 37: 190-197.

Buck, J.W., Walcott, R.R. \& Beuchat, L.R. (2003): Recent trend sin microbiological safety of fruits and vegetables. APSnet, Plant Health Progress, Feature Story, January/February http://www.apsnet.org/publications/apsnetfeatures/Documents/2003/MicrobiologicalSafety.pdf

Cadenas E. (1989): Biochemistry of oxigen-toxicity. Annual Review of Biochemistry, 58:79110.

Caruso, T. \& Liverani, G.D. (1996): Rootstock influences the fruit mineral, sugar and organic acid content of a very early ripening peach cultivar. J.Hort. Sci., 71. 931

Castaneda-Ovando, A., Pacheco-Hernandez M. D., Paez-Hernandez M. E., Rodriguez J. A. és Galan-Vidal C. A. (2009): Chemical studies of anthocyanins: A review. Food Chemistry, (113):859-871.

Chamberlain, D.E., Wilson, J.D., (2000): Ecology and Conservation of Lowland Farmland Birds. British Ornithologists Union, Tring. 
Chand-Goyal, T. \& Spotts, R.A., (1997): Biological control of postharvest diseases of apple and pear under semi-commercial and commercial conditions using three saprophytic yeasts. Biol. Control 10, 199-206.

Clough, Y., Kruess, A., Kleijn, D., Tscharntke, T., 2005. Spider diversity in cereal fields: comparing factors at local, landscape and regional scales. J. Biogeogr. 32, 2007-2014.

Csernus, O., Dobolyi, Cs., Sebők, F., Tóth, M. \& Beczner, J. (2013): Characterisation of the apple surface mycota. 4th Central European Forum for Microbiology, Keszthely. Konferenciakiadvány

DeRoeyer, C., (1998): Microbiological safety evaluations and recommendations on fresh produce. Food Control 9, 321-347.

Dickler, E. (1990): Guidelines and labels defining integrated fruit production in European countries. IOBC/WPRS Bulletin 13. 8 .

Drake, S.R. \& Fellman, J.K. (1987): Indicators of maturity and storage quality of 'Rainier' sweet cherry. HortScience, 22, 282-285.

Duthie (2000): Plant polyphenols in cancer and heart disease: Implications as nutritional antioxidants, Nut. Res. Rev., 13: 79-106.

Emberland, K.E., Ethelberg, S., Kuusi, M., Vold, L., Jensvoll, L., Lindstedt, B.A., Nygård, K., Kjelsø, C., Torpdahl, M., Sørensen, G., Jensen, T., Lukinmaa, S., Niskanen, T., Kapperud, G., (2007): Outbreak of Salmonella Weltevreden infections in Norway, Denmark and Finland associated with alfalfa sprouts, July-October 2007. URL: http://www.eurosulveillance.org/ew/2007/071129.asp.

Faluba, Z., Harsányi, Z., Bödecs, L., Tomcsányi, P. (1982): Gyümölcsfajtákról - Csonthéjasok és héjasgyümölcsüek. Mezőgazdasági Kiadó, Budapest. 88p.

Fernandes, I., Marques, F., Freitas, V., Mateus, N. (2013): Antioxidant and antiproliferative properties of methylated metabolites of anthocyanins. Food. Chem., 141 (3): 2923-33. doi:10.1016/j.foodchem.2013.05.033.Epub 2013 May 18.

Ferrieres, J. (2004): The French Paradox; Lessons for other countries. Heart 90 (1): 107-111. doi:10.1136/heart.90.1.107

Freemark, K.E., Kirk, D.A., (2001): Birds on organic and conventional farms in Ontario: partitioning effects of habitat and practices on species composition and abundance. Biol. Conserv. 101, 337-350.

Gaál M. (2004): A biometria számítógépes alkalmazásai a környezeti és agrártudományokban. Budapest: Aula Kiadó, 147p.

Gibson, R.H., Pearce, S., Morris, R.J., Symondson, W.O.C. \& Memmot, J., (2007): Plant diversity and land use under organic and conventional agriculture: a whole farm approach. $J$. Appl. Ecol. 44, 792-803. 
Gombkötő, G., Sajgó, M.(1985): Biokémia. Budapest: Mezőgazdasági Kiadó, 166-175p.

Granado, J., Thürig, B., Kieffer, E., Petrini, L., Fliessbach, A., Tamm, L., Weibel, F.P. \& Wyss, G.S. (2008):Culturable fungi of stored 'golden delicious' apple fruits: a one-season comparison study of organic and integrated production systems in Switzerland. Microb Ecol. 2008 Nov;56(4):720-32. doi: 10.1007/s00248-008-9391-x. Epub 2008 May 13.

Grieb, S. M. D., Theis, R. P., Burr, D., Benardot, D., Siddiqui, T., \& Asal, N. R. (2009).

Food groups and renal cell carcinoma: Results from a case-control study. Journal of the American Dietetic Association, 109, 656-667.

Gunst, L., Jossi, W., Zihlmann, U., Mäder, P., Dubois, D., (2007): DOK-Versuch: Erträge und Ertragsstabilität 1978-2005. Agrarforschung 14, 542-547.

Gutierrez, E., 1997. Japan prepares as O157 strikes again. Lancet 349, 1156.

Harborne, J. B. (1989): General procedures and measurement of total phenolics. Methods in plant biochemistry. Volume 1 Plant Phenolics, Academic Press, London, pp:1-28.

Harborne, J. B. (1993):The flavonoids: advances in research since 1986. Chapman \& Hall, London, UK 1993.

Harborne, J.B. (1999): Phytochemical dictionary: Handbook of bioactive compounds from plants 2nd (Edn.). Taylor and francis, London, pp:221-234.

Harnos Zs. \& Ladányi M. (2005): Biometria agrártudományi alkalmazásokkal. Budapest: Aula Kiadó, 336p.

Healy, B., Cooney, S., O'Brien, S., Iversen, C., Whyte, P., Nally, J., Callanan, J.J. \& Fanning, S. (2010): Cronobacter (Enterobacter sakazakii): an opportunistic foodborne pathogen. Foodborne Pathog Dis. 2010 Apr;7(4):339-50. doi: 10.1089/fpd.2009.0379.

Hecke, K., Herbinger, K., Verberic, R., Stefancic, M., Toplak, H., Stampar, F., Keppel, H., Grill, D. (2006): Sugar-, acid- and phenol contents in apple cultivars from organic and integrated fruit cultivation. Eur.J. Clin.Nutr., 60 (9):1136-1140.

Herpay, M., Krisztalovics, K., Csohán, Á., Fehér, Á., Pályi, B. \& Tóth, Sz. (2011): Az enteroaggregatív és Shiga toxin-termelö Escherichia coli $\mathrm{O} 104: \mathrm{H} 4$ járvány és hatása Európára. Egészségtudomány, LV., 3.,

Henning SM, Niu Y, Lee NH, Thames GD, Minutti RR, Wang H, Go VL, \& Heber D. (2004): Bioavailability and antioxidant activity of tea flavanols after consumption of green tea, black tea, or a green tea extract supplement. Am J Clin Nutr. 2004 Dec;80(6):1558-64.

Hevesi M., Végh, A., Tóth,M. (2009): A tüzelhalás múltja és jelene. Agrofóum extra 26. szám, 90-91p.

Holb, I. (2005): A gyümölcsösök és a szőlő ökológiai növényvédelme. Budapest: Mezőgazda Kiadó. 
Holzschuh, A., Steffan-Derwenter, I., Kleijn, D., Tscharntke, T., (2007): Diversity of flowervisiting bees in cereal fields: effects of farming system, landscape composition and regional context. J. Appl. Ecol. 44, 41-49.

Hudina, M., Stampar, F. (2005): The correlation of the pear (Pyrus communis L.) cv. 'Williams' yield quality to the foliar nutrition and water regime. Acta agriculturae Slovenica, 85 - 2, november 2005.

Huy, Y.H.,(2006): Handbook of fruits and fruit processing. Blackwell Publishing Ltd., UK.

James, G. (1985): The Science Workbook: Student Research Projects in Food-AgricultureNatural Resources, 1985 Edition, College of Agriculture, Ohio State University

Janisiewicz, W.J., Conway, W. S., Brown, M.W., Sapers, G.M., Fratamico, P. \& Buchanan, L. (1999): Fate of Escherichia coli $\mathrm{O} 157: \mathrm{H} 7$ on fresh-cut apple tissue and its potential for transmission by fruit flies. Appl. environ. Microbiol., 65, 1-5p.

Johannessen, G.S., Lancarevic, S., Kruse, H., (2002): Bacteriological analysis of fresh produce in Norway. International Journal of Food Microbiology 77, 199-204.

Johnston, L.M., Jaykus, L., Moll, D., Martinez, M.C., Anciso, J., Mora, B., Moe, C.L., 2005. A field study on the microbiological quality of fresh produce. Journal of Food Protection 68, $1840-1847$.

Joseph, S., Sonbol, H., Hariri, S., Desai, P., McMclelland, M., Forsythe, S.J. (2012). "Diversity of the Cronobacter genus as revealed by multi locus sequence typing". J Clin Microbiol 50 (9): 3031-3039. doi:10.1128/JCM.00905-12.

Kállay, T., Szenci, Gy., Ficzek, G., Stégerné, M., Bujdosó, G., Szügyi, S., Tóth, M. (2010): Meggyfajták optimális betakarítási idejének meghatározása a gyümölcs leválasztásához szükséges szakítóerő és fontosabb beltartalmi összetevők mérésével. Kertgazdaság 2010/3-4.

Kang, S.Y., Seeram, N.P., Nair, M.G., Bourquin, L.D. (2003): Tart cherry antoyanins inhibit tumor development in Apc Min mice and reduce poliferation of human colon cancer cells. Cancer Lett., 194. 13-19.

Kemény S. (2002): Kísérletek tervezése és értékelése. Budapest: Müszaki Könyvkiadó,492p.

Kenyeres, A. (2009): Legyen több egészséges hazai biogyümölcs. www.gtm.hu/magazin

Larena, I., De Cal, A., Linan, M., \&Melgarejo, P. (2003): Drying of Epicoccum nigrum conidia for obtaining a shelf-stable biological product against brown rot disase. J. Appl. Microbiol. 94 (3): 508-514.

Lásztity, R. (1981): A sav-cukor arány változásai. In: Lásztity, R. (szerk.): Az élelmiszerbiokémia alapjai. Budapest: Mezőgazdasági Kiadó, 234-236p.

Leeuwen, van G.C. M.,Holb I. J. \&Jeger, M.J. (2002): Factors affecting mummification and sporulation of pome fruit infected by Monillinia in Dutch orchards. Plant Path. 51:787-793. 
Leifeld, J. (2012): How sustainable is organic farming? Agriculture, Ecosystem and Environment 150, 121-122p.

Lindow, S. E., McGourty, G. \& Elkins, R. (1996): Interactions of antibiotics with Pseudomonas fluorescens A 506 in the control of fire blight and frost injury of pear. Phytopathology 86:841-848.

Liu, BL; Zhang, X; Zhang, W; Zhen, HN (2007): New enlightenment of French Paradox: resveratrol's potential for cancer chemoprevention and anti-cancer therapy. Cancer biology \& therapy 6 (12): 1833-6.

Looney, N.E., Webster, A.D. \& Kupferman, E.M. (1996): Harvest and handling sweet cherries for the fresh market. -in: Webster, A.D. \& Looney, N.E. (Eds.), Cherries: crop physiology, production and uses. UK, CAB International, p. 513.

Lugasi, A. (2004): Gyümölcs-és zöldséglevek polifenol-tartalma és in vitro antioxidáns tulajdonságai. Alkoholmentes italok 2004/1.

Mukherjee, A., Speh, D., Dyck, E. \& Diez-Gonzalez, F., 2004. Preharvest evaluation of coliforms, Escherichia coli, Salmonella and Escherichia coli O157:H7 in organic and conventional produce grown by Minnesota farmers. Journal of Food Protection 67, 894-900.

Mukherjee, A., Speh, D., Jones, A.T., Buesing, K.M., Diez-Gonzalez, F., (2006): Longitudinal microbiological survey of fresh produce grown by farmers in the upper Midwest. Journal of Food Protection 69, 1928-1936.

Murphy, K.M.., Vampbell, K.G.., Lyon, S. R.., Jones, S. s (2007): Evidence of varietial adaptation to organic farming systems. Field Crops Research 102, 172-177p.

Nagy, P., Szabó, Z., Nyéki, J. \& Soltész, M. (2009): Tavaszi fagyhatás indukálta rendszertelen terméshozás és tápanyag-felvételi anomália integrált almaültetvényekben. „Klíma-21 "füzetek, 58. szám, 59-64p.

Nicholson, F.A., Groves, S.J. \& Chambers, B.J. (2005): Pathogen survival during livestock manure storage and following land application. Biores. Tech., 96, 135-143.

Nguyen, M.L., Haynes, R.J., Goh, K.M., (1995): Nutrient budgets and status in 3 pairs of conventional and alternative mixed cropping farms in Canterbury, New- Zealand. Agriculture Ecosystems \& Environment 52, 149-162.

Norton, L.; Johnson, P.;,Joys, A.,; Stuart, R., Chamberlain, D, Feber, R.,; Firbank, L.; Manley, W., Wolfe, M.; Hart, B.,; Mathews, F., Macdonald, D., Fuller, R. J.L. (2009): Consequences of organic and non-organic farming practices for field, farm and landscape complexity. Agriculture, Ecosystems and Environment 129, 221-227p.

Nygård, K., Lassen, J., Vold, L., Aavitsland, P., (2004): E-alert: outbreak of Salmonella Thompson infections caused by contaminated ruccola (rocket) salad. URL: http://www.eurosurveillance.org/ew/2004/041125.asp. 
Nyéki, J. (2008): Szakmai beszámoló a „bio/organikus és integrált gyümölcstermesztést megalapozó biológiai alapok fejlesztése és technológiák kidolgozása" című Jedlik Ányos pályázathoz.

Offermann, F., Nieberg, H., (2001): Wirtschaftliche Situation okologischer Betriebe in ausgewahlten Ländern Europas: Stand, Entwicklung und wichtige Einflussfaktoren. Agrarwirtschaft 50, 421-427.

Omeg, M. \& Omeg, L. (2005): Physiological principles for growing premium fruit. -in: Whiting, M. (Ed.) Producing premium cherries. Good fruit growers. PNW Cherry short course Proceedings, pp. 145-148.

Pantelidis, G. E., Vasilakakis M., Manganaris G. A. és Diamantidis G. (2007): Antioxidant capacity, phenol, anthocyanin and ascorbic acid contents in raspberries, blackberries, red currants, gooseberries and cornelian cherries. Food Chemistry, (102):777-783.

Papp, D., Ficzek, G., Stégerné, M., Nótin, B., Király, I., Tóth, M. (2011): Kárpát-medencei régi almafajták beltartalmi értékei és perspektívái a XXI. Század hazai gyümölcsnemesítésében. Kertgazdaság 2011/1.

Papp N, Szilvassy B, Abranko L, Szabo T, Pfeiffer P, Szabo Z, Nyeki J, Ercisli S, StefanovitsBanyai E, Hegedus A (2010): Main quality attributes and antioxidants in Hungarian sour cherries: identification of genotypes with enhanced functional properties. INTERNATIONAL JOURNAL OF FOOD SCIENCE AND TECHNOLOGY 45: (2) pp. 395-402.

Paszternák, F., Vályi, I. \& Nyéki, J. (1982): A vegyszeres kezelések hatása a Pándy meggy gyümölcskötődésére és a monília jelentősége az üzemi ültetvényekben. Növényvédelem 18 (9): 407-411.

Pezzoli, L., Elson, R., Little, C., Fisher, I., Yip, H., Peters, T., Hampton, M., De Pinna, E., Coia, J.E., Mather, H.A., Brown, D.J., Møller-Nielsen, E., Ethelberg, S., Heck, M., de Jager, C., Threlfall, J., (2007): International outbreak of Salmonella Senftenberg in 2007. URL: http://www.eurosurveillance. org/ew/2007/070614.asp.

Predieri, S., Ramdane, D. \& Rapparini, F. (2004): Influence of growing conditions on yield and quality of cherry: II. Fruit quality. Food, Agriculture \& Environment Vol.2 (1): 307-309pp.

Revell, J. (2008): Sensory profile and consumer acceptability of sweet cherries. Thesis submitted to the University of Nottingham for the degree of Masters of Research.

Rice-Evans (1996): Structure-antioxidant activity relationships of flavonoids and phenolic acids, Free Radical Biol. Med., 20: 933-956.

Rodrigo, E. (2000): Spring frost in deciduous fruit trees - morphological damage and flowers hardiness. Scientia Hort. 85, 155-173. pp.

Roschewitz, I., Gabriel, D., Tscharntke, T., Thies, C., (2005): The effects of landscape complexity on arable weed species diversity in organic and conventional farming. J. Appl. Ecol. $42,873-882$. 
Róth, E., Berna, A., Beullens, K., Yarramraju, S., Lammertyn, J., Schenk, A., Nicolai, B. (2007): Postharvest quality of integrated and organically produced apple fruit. Postharvest Biology and Technology, 45:11-19.

Rundlof, M., Smith, H.G., (2006): The effect of organic farming on butterfly diversity depends on landscape context. J. Appl. Ecol. 43, 1121-1127.

Ryan, M.H., Derrick, J.W., Dann, P.R., (2004): Grain mineral concentrations and yield of wheat grown under organic and conventional management. J. Sci. Food Agric. 84, 207-216.

Santos-Buelga \& Gary Williamson (2004): Methods in Polyphenol Analysis. Royal Society of Chemistry, Cambridge, 384 pages

Scalzo, J., Pliti, A., Pellegrini, N., Mezzetti, B., Battino, M. (2005): Plant genotype affect total antioxidant capacity and phenolic contents in fruit. Nutrition, 21. 207-213.

Schmidt, M.H., Roschewitz, I., Thies, C., Tscharntke, T., (2005): Differential effects of landscape and management on diversity and density of ground-dwelling farmland spiders. $J$. Appl. Ecol. 42, 281-287.

Shahidi \& Naczk (1995): Food phenolics: Sources, Chemistry, Effects, Applications, Technomic Publishing Company Inc., Lancaster PA., pp: 231-245.

Silaste, M. L., Alfthan, G., Aro, A., Kesaniemi, Y. A., \& Horkko, S. (2007). Tomato juice decreases LDL cholesterol levels and increases LDL resistance to oxidation. British Journal of Nutrition, 98, 1251-1258.

Singleton, V.L., Rossi, J.A. (1965): Colorimetry of total phenolics with phosphomolibdicphosphotungstic acid reagents. Am. J. Enol. Vit., 161. 144-158.

Slimestad, R. és Solheim H. (2002): Anthocyanins from black currants (Ribes nigrum L.). Journal of Agricultural and Food Chemistry, (50):3228-3231.

Soltész, M. (2005): Integrált gyümölcstermesztés. Elektronikus Felsőoktatási Tankönyv - és Szakkönyvtár. http: // www.tankönyvtar.hu

Soltész, M., Nyéki, J., Szabó, Z., Lakatos, L., Racskó, J., Holb, I., Thurzó, S. (2006): Az éghajlat-és időjárás-változás alkalmazkodási stratégiája a gyümölcstermelésben. In: Csete L., Nyéki, J., (szerk.): Klímaváltozás és a magyarországi kertgazdaság. „AGRO-21” Kutatási programiroda. AKAPRINT Kft., Budapest, 11-101pp.

Soltész M., Nyéki, J., Szabó, Z., Lakatos, L. (2008): Globális éghajlatváltozás - az alföldi gyümölcstermesztés lehetőségei. AGTEDU 2008 Konferencia kiadvány, 136-141. pp.

Söderström, A., Lindberg, A., Andersson, Y., (2005): EHEC O157 outbreak in Sweden from locally produced lettuce, August-September $2005 . \quad$ URL: http://www.eurosurveillance.org/ew/2005/050922.asp.

Stanhill, G., 1990. The comparative productivity of organic agriculture. Agric. Ecosyst. Environ. 30, 1-26p. 
Szabó, Z., Lakatos, L., Nyéki, J., Racskó, J., Soltész, M. (2010) A gyümölcsminőséget befolyásoló fajtatulajdonságok, fiziológiai és klimatológiai tényezők vizsgálata = Examination of cultivar properties, physiological and agroclimatic factors influencing fruit quality parameters. Munkabeszámoló. OTKA.

Szücs I. (2004): Alkalmazott Statisztika. Budapest: AGROINFORM Kiadó és Nyomda Kft. $551 \mathrm{p}$.

Tilman, D., Cassman, K.G., Matson, P.A, Naylor, R., Polasky, S. (2002): Agricultural sustainability and intensive production practices. Nature 418, 671-677.

Tomek, P., Bert, R., Martin, K.I. (2012): The crop yield gap between organic and conventional agriculture. Agricultural Systems 108, 1-9.

Tóth, M. (2009): Gyümölcsfaj-és fajtaismeret. Egyetemi jegyzet. BCE-Kertészettudományi Kar. 234p.

Tóth-Markus, M; Adányi, N., Boross, F., Daood, H.G., Bánáti, D., Szabó, T. \& Nyéki, J. (2010): Comparison of apples from organic and integrated farming. International Journal of Horticultural Science 2010, 16 (3): 15-18.

Tóthné Lőkös K. (2011) : Biometria. Gödöllő: Szent István Egyetem Kiadó, 236p.

Tournas, V.H., 2005. Moulds and yeasts in fresh and minimally processed vegetables, and sprouts. International Journal of Food Microbiology 99, 71-77.

Tournas, V.H., Heeres, J., Burgess, L., 2006. Moulds and yeast in fruit salads and fruit juices. Food Microbiology 23, 684-688.

Treutter, D. (2005): Significance of flavonoids in plant resistance and enhancement of their biosynthesis. Plant Biology, 7:581-591.

Tyrrel, S.F. \& Quinton, J. N. (2003): Overland flow transport of pathogens from agricultural land receiving faecal wastes. J. appl. Microbiol., 94, 87S-93S.

Wells, J.M. \& Butterfield, J.E. (1997): Salmonella contamination associated with bacterial soft rot of fresh fruits and vegetables int he marketplace. Plant Disease, 81, 867-872.

Wojciech, J., Janisiewicz W.J. \& Lise Korsten (2002): Biological control of postharvest diseases of fruits. Annual Review of Phytopathology. Vol. 40: 411-441 (Volume publication date September 2002). DOI: 10.1146/annurev.phyto.40.120401.130158

Wrolstad, R.E., Durst, R. W., \& Lee, J.(2005): Tracking color and pigment changes in anthocyanin products. Trends in Food Science and Technology, 16 (9):423-428.

Wu, X., Beecher, GR., Holden, J.M., Haytowitz, D.B., Gebhardt, S.E., Prior, R. L. (2004): Lipophilic and hydrophilic antioxidant capacities of common foods in the United States. $J$. Agric Food Chem. 16;52(12):4026-37.

Zhang, C. X., Ho, S. C., Chen, Y. M., Fu, J. H., Cheng, S. Z., \& Lin, F. Y. (2009). Greater 
vegetable and fruit intake is associated with a lower risk of breast cancer among Chinese women. International Journal of Cancer, 125, 181-188.

Internetes forrás:

$\underline{\text { www.ksh.hu; } \text { www.hvgonline.hu }}$

Szabványok jegyzéke:

MSZ 9474-80 Borok polifenol-tartalmának meghatározása

MSZ 9697-1:1982 Gyümölcsök vizsgálata. Általános elöírások

MSZ EN 12143:1998 Gyümölcs-és zöldséglevek. Az oldható szárazanyag-tartalom becslése. Refraktometriás módszer

MSZ ISO 750:2001 Gyümölcs- és zöldségtermékek titrálható savtartalmának meghatározása

MSZ EN ISO 4833 Mezofil aerob összes élőcsíraszám meghatározása

MSZ ISO 7954 Élesztő- és penészgomba szám meghatározása

MSZ ISO 21528-2 Enterobacteriaceae szám meghatározása

MSZ 3640/18-79 és MSZ 364019-79 Kóliform-, Escherichia coli szám meghatározása

MSZ 3640/7-80 Pseudomonas aeruginosa szám meghatározása

MSZ EN ISO 112900:1998 Listeria monocytogenes meghatározása

MSZ EN ISO 6579:2002 Salmonella spp. meghatározása

ISO /TS 22964:2006 (IDF/RM 210:2006) Enterobacter sakazakii meghatározása 


\section{M2. Táblázatok}

1.táblázat: Csonthéjas gyümölcsök átmérője és súlya

\begin{tabular}{|c|c|c|c|c|c|c|}
\hline gyümölcs & dátum, termőhely & átmérő átlag & legnagyobb átmérö & legkisebb átmérő & $\begin{array}{c}\text { egy szem átlag súly } \\
\text { maggal }\end{array}$ & $\begin{array}{l}\text { egy szem átlag súly } \\
\text { mag nélkül } \\
\end{array}$ \\
\hline cseresznye: & & $\mathrm{cm}$ & $\mathrm{cm}$ & $\mathrm{cm}$ & $\mathrm{g}$ & $\mathrm{g}$ \\
\hline Firm Red integrált & 2008.VI.5. Nagykutas & 2,86 & 3,15 & 2,62 & 10,6 & 9,5 \\
\hline Firm Red integrált & 2009.VI.08.Nagykutas & 2,49 & 2,95 & 2,12 & 7,9 & 7,13 \\
\hline Firm Red integrált & 2010.VI.14. Nagykutas & 2,9 & 3,65 & 2,64 & 10,01 & 9,25 \\
\hline Katalin integrált & 2008.VII.2. Nagykutas & 2,69 & 2,94 & 2,4 & 12,5 & 11,7 \\
\hline Katalin integrált & 2009.VI.30. Nagykutas & 2,74 & 3,03 & 2,42 & 11,4 & 10,63 \\
\hline Katalin integrált & 2010.VI.28. Nagykutas & 2,6 & 2,75 & 2,41 & 8,172 & 7,37 \\
\hline Regina integrált & 2008.VII.2. Nagykutas & 2,72 & 3,1 & 2,52 & 11,5 & 10,6 \\
\hline Regina integrált & 2009.VI.30. Nagykutas & 2,73 & 3,12 & 2,49 & 11,1 & 10,17 \\
\hline Regina integ & 2010.VII.05.Nagykutas & 2,9 & 3,09 & 2,64 & 11,314 & 10,35 \\
\hline \multicolumn{7}{|l|}{ meggy } \\
\hline Érdi Bőtermő bio & 2008.VI.23. Nyíregyháza & 2,14 & 2,4 & 1,74 & 7,0 & 6,4 \\
\hline Érdi Bőtermő integrált & 2008.VI.23.Ujfehértó & 1,97 & 2,23 & 1,66 & 6,7 & 6,1 \\
\hline Érdi bőtermő integrált & 2009.VI.15 Újfehértó & 2,1 & 2,32 & 1,76 & 6,5 & 5,9 \\
\hline Érdi bőtermő integrált & 2010.VI.21. Újfehértó & 2,10 & 2,32 & 1,85 & 6,06 & 5,49 \\
\hline Érdi bőtermő bio & 2010.VI.21. Kabalás & 2,13 & 2,35 & 1,79 & 6,37 & 5,79 \\
\hline VN-1 integrált & 2008.VI.18.Ujfehértó & 1,84 & 2,14 & 1,56 & 4,6 & 4,1 \\
\hline VN-1 integrált & 2009.VI.08.Ujfehértó & 1,8 & 2,07 & 1,65 & 4,6 & 4,2 \\
\hline VN-1 integrált & 2010.VI.14.Újfehértó & 2,0 & 2,3 & 1,82 & 3,9 & 3,5 \\
\hline VN-4 integrált & 2008.VII.1. Újfehértó & & & & & \\
\hline VN-4 integrált & 2009.VI.15 Újfehértó & 1,85 & 2,12 & 1,62 & 4,71 & 4,08 \\
\hline VN-4 integrált & 2010.VI.14.Újfehértó & 1,93 & 2,20 & 1,80 & 3,74 & 3,33 \\
\hline VN-4 változat integrált & 2010.VI.28. Újfehértó & 1,9 & 2,18 & 1,7 & 4,9 & 4,2 \\
\hline VN-7 integrált & 2008.VI.19 SZ.F. & 2,06 & 2,26 & 1,74 & 6,6 & 6,0 \\
\hline VN-7 integrált & 2009.VI.15 Újfehértó & 2,0 & 2,23 & 1,82 & 5,4 & 4,9 \\
\hline
\end{tabular}




\begin{tabular}{|c|c|c|c|c|c|c|}
\hline gyümölcs & dátum, termőhely & átmérő átlag & legnagyobb átmérő & legkisebb átmérő & $\begin{array}{c}\text { egy szem átlag súly } \\
\text { maggal }\end{array}$ & $\begin{array}{l}\text { egy szem átlag súly } \\
\text { mag nélkül }\end{array}$ \\
\hline & & $\mathrm{cm}$ & $\mathrm{cm}$ & $\mathrm{cm}$ & $\mathrm{g}$ & $\mathrm{g}$ \\
\hline VN-7 integrált & 2010.VI.14. Lövőpetri & 2,2 & 2,395 & 2,01 & 5,2 & 4,6 \\
\hline VN-7 érett integrált & 2010.VI.21. Lövőpetri & 2,1 & 2,32 & 1,85 & 5,4 & 4,8 \\
\hline Oblacsinszka integálr & 2008. VI. 23.Ujfehértó & 1,66 & 1,85 & 1,5 & 4,0 & 3,4 \\
\hline Oblacsinszka integrált & 2010.VI.28. Újfehértó & 1,8 & 1,96 & 1,65 & 4,1 & 3,5 \\
\hline Csengődi integrált & 2008. VI. 23.Ujfehértó & 2,03 & 2,25 & 1,83 & 5,8 & 5,1 \\
\hline Csengödi integrált & 2009. VI.15 Újfehértó & 1,88 & 2,10 & 1,65 & 5,3 & 4,6 \\
\hline Csengődi integrált & 2010. VI.28. Újfehértó & 1,94 & 2,12 & 1,79 & 5,11 & 4,51 \\
\hline Újfehértói fürtös bio & 2008. VII.5. Nyiregyháza & 1,97 & 2,22 & 1,75 & 5,3 & 4,8 \\
\hline Újfehértói fürtös integrált & 2008. . VII.7. Újfehértó & 1,94 & 2,15 & 1,75 & 5,3 & 4,8 \\
\hline Újfehértói fürtös integrált & 2009. VI.29. Újfehértó & 2,13 & 2,39 & 1,89 & 5,9 & 5,3 \\
\hline Újfehértói fürtös integrált & 2009. VII.06.Ujfehértó & 1,86 & 2,60 & 1,65 & 4,7 & 4,3 \\
\hline Újfehértói fürtös bio & 2009. VI.29. Nyiregyháza & 2,26 & 2,52 & 1,91 & 6,7 & 6,0 \\
\hline Ujfehértói fürtös integrált & 2010.VII.05. Újfehértó & 2,09 & 2,28 & 1,92 & 6,22 & 5,64 \\
\hline Ujfehértói fürtös bio & 2010.VII.05. Kabalás & 1,99 & 2,21 & 1,85 & 5,46 & 4,91 \\
\hline 'Kántorjánosi 3' bio & 2008. VII.5. Nyiregyháza & 1,92 & 2,13 & 1,65 & 5,2 & 4,7 \\
\hline 'Kántorjánosi 3' integrált & 2008. VII.7. Újfehértó & 2,00 & 2,3 & 1,66 & 5,7 & 5,1 \\
\hline 'Kántorjánosi 3' bio & 2009. VI.29 Nyiregyháza & 2,25 & 2,45 & 2,05 & 6,6 & 6,0 \\
\hline 'Kántorjánosi 3' integrált & 2009. VI.29. Újfehértó & 2,23 & 2,48 & 1,85 & 6,1 & 5,5 \\
\hline 'Kántorjánosi 3' integrált & 2009. VII.06 Újfehértó & 1,89 & 2,10 & 1,70 & 5,9 & 5,3 \\
\hline 'Kántorjánosi 3' integrált & 2010.VII.05. Újfehértó & 2,11 & 2,38 & 1,75 & 6,22 & 5,64 \\
\hline 'Kántorjánosi 3’ bio & 2010.VII.05. Kabalás & 2,10 & 2,35 & 1,93 & 6,06 & 5,49 \\
\hline Éva integrált & 2008. VII.4. Újfehértó & 2,04 & 2,3 & 1,72 & 5,9 & 5,3 \\
\hline Éva integrált & 2009.VII. 06 Újfehértó & 1,91 & 2,03 & 1,73 & 6,1 & 5,4 \\
\hline Éva integrált & 2010.VII.09. Újfehértó & 2,0 & 2,21 & 1,8 & 5,1 & 4,6 \\
\hline Petri integrált & 2008. VII.5. Újfehértó & 2,11 & 2,42 & 1,85 & 6,3 & 5,7 \\
\hline Petri integrált & 2009. VII.06 Újfehértó & 2,05 & 6,91 & 1,79 & 6,1 & 5,5 \\
\hline
\end{tabular}




\begin{tabular}{|c|c|c|c|c|c|c|}
\hline gyümölcs & dátum, termőhely & átmérő átlag & legnagyobb átmérő & legkisebb átmérö & $\begin{array}{c}\text { egy szem átlag súly } \\
\text { maggal }\end{array}$ & $\begin{array}{l}\text { egy szem átlag súly } \\
\text { mag nélkül }\end{array}$ \\
\hline & & $\mathrm{cm}$ & $\mathrm{cm}$ & $\mathrm{cm}$ & $\mathrm{g}$ & $\mathrm{g}$ \\
\hline Petri integrált & 2010.VII.09. Újfehértó & 2,0 & 2,25 & 1,83 & 5,4 & 4,9 \\
\hline Debreceni Bőtermő integrált & 2008. VII.3. Újfehértó & 2,09 & 2,25 & 1,8 & 5,7 & 5,2 \\
\hline Debreceni Bőtermő bio & 2008. VII.5. Nyíregyháza & 2,11 & 2,42 & 1,82 & 6,4 & 5,8 \\
\hline Debreceni bőtermő bio & 2009. VI.29. Nyiregyháza & 2,33 & 2,62 & 1,96 & 7,6 & 6,9 \\
\hline Debreceni bőtermő integrált & 2009. VI.29 Újfehértó & 2,01 & 2,40 & 1,77 & 5,0 & 4,4 \\
\hline Debreceni bőtermő integrált & 2009. VII.06 Újfehértó & 1,84 & 2,00 & 1,67 & 4,7 & 4,2 \\
\hline Debreceni bőtermő integ & 2010.VII.05. Újfehértó & 2,0 & 2,25 & 1,72 & 5,4 & 4,9 \\
\hline Debreceni bőtermő bio & 2010. VII.05. Kabalás & 2,3 & 2,45 & 1,93 & 7,1 & 6,5 \\
\hline "D" integrált & 2009. VII.06 Újfehértó & 1,97 & 2,75 & 1,81 & 6,3 & 5,6 \\
\hline Pipacs integrált & 2009. VII.06 Újfehértó & 1,91 & 2,12 & 1,73 & 6,1 & 5,5 \\
\hline
\end{tabular}


2. táblázat: Csonthéjas gyümölcsök egyes beltartalmi jellemzői

\begin{tabular}{|c|c|c|c|c|c|c|c|c|}
\hline gyümölcs & dátum, termőhely & Brix & $\begin{array}{l}\text { titr sav } \\
\mathrm{pH} 8,1\end{array}$ & $\begin{array}{l}\text { titr sav } \\
\mathrm{pH} 8,1\end{array}$ & polifenol & polifenol & DPPH & DPPH \\
\hline & & & átlag & szórás & átlag & szórás & átlag & szórás \\
\hline cseresznye: & & fok & $\mathrm{g} / \mathrm{kg} \mathrm{CS}$ & $\mathrm{g} / \mathrm{kg} \mathrm{CS}$ & $\mathrm{mg} / \mathrm{kg}$ & $\mathrm{mg} / \mathrm{kg}$ & $\mathrm{mmol} / \mathrm{kg}$ & $\mathrm{mmol} / \mathrm{kg}$ \\
\hline Firm Red integrált & 2008.VI.5. Nagykutas & 18,8 & 5,89 & 0,04 & 968 & 108 & 5,4 & 0,7 \\
\hline Firm Red integrált & 2009.VI.08. Nagykutas & 18,1 & 7,1 & 0,16 & 1095 & 32 & 7,3 & 0 \\
\hline Firm Red integrált & 2010.VI.14. Nagykutas & 16,7 & 6,58 & 0 & 954 & 16 & 6,9 & 0,3 \\
\hline Katalin integrált & 2008.VII.2. Nagykutas & 16,6 & 6,56 & 0,04 & 1051 & 66 & 10,3 & 0,1 \\
\hline Katalin integrált & 2009.VI. 30. Nagykutas & 15,7 & 5,72 & 0,02 & 749 & 1 & 4,6 & 0,1 \\
\hline Katalin integrált & 2010.VI.28. Nagykutas & 13,9 & 4,59 & 0 & 440 & 10 & 3,6 & 0,1 \\
\hline Regina integrált & 2008.VII.2. Nagykutas & 17,4 & 5,86 & 0,01 & 885 & 93 & 7,9 & 0,3 \\
\hline Regina integrált & 2009.VI. 30. Nagykutas & 15,5 & 4,91 & 0,02 & 804 & 12 & 4,8 & 0,1 \\
\hline Regina integrált & 2010.VII.05.Nagykutas & 17,3 & 5,49 & 0,01 & 524 & 17 & 4,1 & 0 \\
\hline \multicolumn{9}{|l|}{ meggy: } \\
\hline "D" & 2009.VII.06 Újfehértó & 14,6 & 11,98 & 0,03 & 1442 & 165 & 13,4 & 1 \\
\hline Cigány 59 integrált & 2008.VI.30. Ujfehértó & & & & 2217 & 34 & 21,6 & 0 \\
\hline Cigány $7 / 1$ integrált & 2008.VI.30. Ujfehértó & & & & 1803 & 66 & 19,2 & 1,9 \\
\hline Cigány C404 integrált & 2008.VI.30. Ujfehértó & & & & 2452 & 86 & 25,2 & 0,8 \\
\hline Cigány59 integrált & 2010.VI.21. Újfehértó & 16,7 & 19,7 & 0,01 & 1962 & 15 & 17,6 & 0,7 \\
\hline Cigány7 integrált & 2010.VI.21. Újfehértó & 16,6 & 19,04 & 0,01 & 2128 & 30 & 19 & 0,6 \\
\hline Csengődi integrált & 2008.VI. 23.Ujfehértó & 16,6 & 10,35 & 0,34 & 2326 & 86 & 22,5 & 0,1 \\
\hline Csengődi integrált & 2009.VI.15 ujfehértó & 15,9 & 9,17 & 0,22 & 1628 & 20 & 12,5 & 0,3 \\
\hline Csengődi integrált & 2010.VI.28. Újfehértó & 14,5 & 8,37 & 0 & 1256 & 3 & 13,5 & 0,4 \\
\hline Debreceni bőtermő bio & 2008.VII.5. Nyíregyháza & 15,4 & 11,08 & 0,02 & 1283 & 58 & 15,2 & 1 \\
\hline Debreceni bőtermő integrált & 2008.VII.3. Ujfehértó & 18,5 & 12,57 & 0,09 & 1689 & 98 & 18 & 1 \\
\hline Debreceni bőtermő bio & 2009.VI.29. Nyiregyháza & 15,5 & 11,92 & 0,19 & 1033 & 42 & 9,8 & 0,3 \\
\hline
\end{tabular}




\begin{tabular}{|c|c|c|c|c|c|c|c|c|}
\hline gyümölcs & dátum, termőhely & Brix & $\begin{array}{l}\text { titr sav } \\
\mathrm{pH} 8,1 \\
\end{array}$ & \begin{tabular}{|l} 
titr sav \\
$\mathrm{pH} 8,1$ \\
\end{tabular} & polifenol & polifenol & DPPH & DPPH \\
\hline & & & átlag & szórás & átlag & Szórás & átlag & szórás \\
\hline & & fok & $\mathrm{g} / \mathrm{kg} \mathrm{CS}$ & $\mathrm{g} / \mathrm{kg} \mathrm{CS}$ & $\mathrm{mg} / \mathrm{kg}$ & $\mathrm{mg} / \mathrm{kg}$ & $\mathrm{mmol} / \mathrm{kg}$ & $\mathrm{mmol} / \mathrm{kg}$ \\
\hline Debreceni bőtermő integrált & 2009. VI.29 Ujfehértó & 16,8 & 13,69 & 0,16 & 1009 & 39 & 11 & 2 \\
\hline Debreceni bőtermő integrált2 & 2009.VII.06 Újfehértó & 16,1 & 13,12 & 0,12 & 1352 & 17 & 9,8 & 0,4 \\
\hline Debreceni bőtermő bio & 2010.VII.05. Kabalás & 15,2 & 13,36 & 0,08 & 971 & 13 & 7 & 1,3 \\
\hline Debreceni bőtermő integrált & 2010.VII.05. Újfehértó & 13,8 & 11,69 & 0,03 & 864 & 57 & 6,7 & 1 \\
\hline Érdi Bőtermő bio & 2008.VI. 23. Nyíregyháza & 15,6 & 9,49 & 0,03 & 1380 & 51 & 13,9 & 1,1 \\
\hline Érdi bőtermő integrált & 2008.VI. 23.Ujfehértó & 15,8 & 9,18 & 0,24 & 1413 & 76 & 15,3 & 1,6 \\
\hline Érdi bőtermő integrált & 2009. VI.15 Ujfehértó & 16,8 & 10,72 & 0,08 & 1232 & 10 & 10,2 & 0,1 \\
\hline Érdi bőtermő bio & 2010.VI.21. Kabalás & 15,5 & 12,78 & 0,08 & 925 & 94 & 9,3 & 0,1 \\
\hline Érdi bőtermő integrált & 2010.VI.21. Újfehértó & 15,8 & 10,56 & 0,03 & 932 & 98 & 8,9 & 0,6 \\
\hline Éva integrált & 2008.VII.4. Ujfehértó & 18,8 & 13,8 & 0,08 & 1639 & 3 & 18,5 & 0,2 \\
\hline Éva integrált & 2009.VII. 06 Újfehértó & 15,9 & 14,24 & 1,04 & 1207 & 9 & 13,7 & 0,1 \\
\hline Éva integrált & 2010.VII.09. Újfehértó & 19,3 & 14,8 & 0,04 & 1384 & 23 & 10,5 & 0,1 \\
\hline 'Kántorjánosi 3' bio & 2008.VII.5. Nyiregyháza & 17,2 & 16,44 & 0,07 & 1732 & 43 & 19,8 & 0,4 \\
\hline 'Kántorjánosi 3' integrált & 2008.VII.7. Újfehértó & 18,9 & 13,48 & 0,09 & 1915 & 89 & 20,5 & 1,7 \\
\hline 'Kántorjánosi 3’ bio & 2009.VI.29 Nyiregyháza & 17,3 & 14,96 & 0,18 & 1376 & 14 & 12 & 0 \\
\hline 'Kántorjánosi 3' integ & 2009.VI.29. Ujfehértó & 17,4 & 13,12 & 0,04 & 1198 & 4 & 11,2 & 0 \\
\hline 'Kántorjánosi 3' integrált2 & 2009.VII.06 Ujfehértó & 16,1 & 14,36 & 0,34 & 1422 & 221 & 15,5 & 0,8 \\
\hline 'Kántorjánosi 3' bio & 2010.VII.05. Kabalás & 18,2 & 19,37 & 0,03 & 1398 & 86 & 11,6 & 0,1 \\
\hline ‘Kántorjánosi 3’ integrált & 2010.VII.05. Újfehértó & 19,5 & 14,61 & 0,03 & 1385 & 42 & 11 & 0,9 \\
\hline Oblacsinszka integrált & 2008.VI. 23.Ujfehértó & 16,8 & 19 & 0,46 & 2551 & 22 & 23,1 & 0,4 \\
\hline Oblacsinszka integrált & 2010.VI.28. Újfehértó & 16,5 & 20,6 & 0,02 & 1715 & 33 & 14,8 & 0,2 \\
\hline Pándy 279 integrált & 2008.VII.1. Ujfehértó & & & & 1266 & 89 & 13,2 & 0,4 \\
\hline Pándy 279 integrált & 2010.VII.05. Újfehértó & 16 & 13,91 & 0,08 & 669 & 26 & 7,3 & 0,2 \\
\hline Petri integrált & 2008.VII.5. Újfehértó & 17 & 13,69 & 0,03 & 1548 & 42 & 16,8 & 1 \\
\hline Petri integrált & 2009.VII.06 Újfehértó & 15,6 & 14,28 & 0,74 & 1388 & 59 & 14,5 & 0,8 \\
\hline
\end{tabular}




\begin{tabular}{|c|c|c|c|c|c|c|c|c|}
\hline gyümölcs & dátum, termőhely & Brix & $\begin{array}{l}\text { titr sav } \\
\mathrm{pH} 8,1 \\
\end{array}$ & \begin{tabular}{|l|} 
titr sav \\
$\mathrm{pH} 8,1$ \\
\end{tabular} & polifenol & polifenol & DPPH & DPPH \\
\hline & & & átlag & szórás & átlag & szórás & átlag & szórás \\
\hline & & fok & $\mathrm{g} / \mathrm{kg} \mathrm{CS}$ & $\mathrm{g} / \mathrm{kg} \mathrm{CS}$ & $\mathrm{mg} / \mathrm{kg}$ & $\mathrm{mg} / \mathrm{kg}$ & $\mathrm{mmol} / \mathrm{kg}$ & $\mathrm{mmol} / \mathrm{kg}$ \\
\hline Petri integrált & 2010.VII.09. Újfehértó & 16 & 13,79 & 0,02 & 861 & 44 & 6,5 & 0,1 \\
\hline Pipacs integrált & 2009.VII.06 Újfehértó & 20,2 & 21,34 & 0,32 & 6230 & 181 & 58,4 & 0,5 \\
\hline Ujfehértói fürtös bio & 2008.VII.5. Nyiregyháza & 17,8 & 14,72 & 0,08 & 1928 & 40 & 19,8 & 1,2 \\
\hline Ujfehértói fürtös integrált & 2008.VII.7. Ujfehértó & 19,1 & 17,01 & 0,09 & 1645 & 38 & 16,2 & 1 \\
\hline Újfehértói fürtös bio & 2009.VI.29. Nyiregyháza & 16,5 & 13,45 & 0,05 & 1352 & 10 & 11,2 & 0,3 \\
\hline Újfehértói fürtös integrált & 2009. VI.29. Ujfehértó & 18 & 14,02 & 0,26 & 1430 & 21 & 13,9 & 0,7 \\
\hline Újfehértói fürtös integrált2 & 2009.VII.06.Ujfehértó & 17 & 19,29 & 0,07 & 1513 & 36 & 15,3 & 0,6 \\
\hline Ujfehértói fürtös bio & 2010.VII.05. Kabalás & 17,3 & 19,34 & 0,02 & 1222 & 89 & 8,9 & 0 \\
\hline Ujfehértói fürtös integrált & 2010.VII.05. Újfehértó & 17,8 & 15,71 & 0,01 & 922 & 83 & 6,7 & 1 \\
\hline VN-1 integrált & 2008.VI.18.Ujfehértó & 20,5 & 11,24 & 0,75 & 3490 & 199 & 32,2 & 2,1 \\
\hline VN-1 integrált & 2009.VI.08.Ujfehértó & 21,1 & 10,07 & 0,11 & 3085 & 83 & 26,3 & 0,3 \\
\hline VN-1 integrált & 2010.VI.14.Újfehértó & 20 & 11,11 & 0,03 & 1847 & 82 & 15,7 & 0,7 \\
\hline VN-4 integrált & 2008.VII.1. Ujfehértó & & & & 2134 & 42 & 23,5 & 1,3 \\
\hline VN-4 integrált & 2009.VI.15 ujfehértó & 16,80 & 9,92 & 0,08 & 1748 & 106 & 14,50 & 1 \\
\hline VN-4 integrált & 2010.VI.14.Újfehértó & 20,20 & 10,3 & 0,01 & 1800 & 61 & 15,80 & 0,3 \\
\hline VN-4 változat integrált & 2010.VI.28. Újfehértó & 19,3 & 9,07 & 0,05 & 1927 & 138 & 18,3 & 0 \\
\hline VN-7 integrált & 2008.VI. 19 SZ.F. & 16 & 11,29 & 0,87 & 2156 & 104 & 22,4 & 0,8 \\
\hline VN-7 integrált & 2009.VI.15 ujfehértó & 17,8 & 10,89 & 0,18 & 2175 & 15 & 19,3 & 0,4 \\
\hline VN-7 integrált & 2010.VI.14. Lövőpetri & 14,3 & 12,96 & 0,02 & 1317 & 14 & 11 & 0 \\
\hline VN-7 integrált érett & 2010.VI.21. Lövőpetri & 15,6 & 12,8 & 0,01 & 1687 & 7 & 15,9 & 0,1 \\
\hline
\end{tabular}


3. táblázat: Meggy tárolási kísérletek

\begin{tabular}{|c|c|c|c|c|c|c|c|c|c|c|}
\hline gyümölcs & kitárolási dátum, termőhely & Brix & \begin{tabular}{|l|} 
titr sav \\
$\mathrm{pH} 7$
\end{tabular} & \begin{tabular}{|l|} 
titr sav \\
$\mathrm{pH} 7$
\end{tabular} & $\begin{array}{l}\text { titr sav pH } \\
8,1 \\
\end{array}$ & \begin{tabular}{|l} 
titr sav \\
$\mathrm{pH} 8,1$ \\
\end{tabular} & polifenol & polifenol & DPPH & DPPH \\
\hline & & & átlag & szórás & átlag & szórás & átlag & szórás & átlag & szórás \\
\hline & & fok & $\mathrm{g} / \mathrm{kg} \mathrm{BS}$ & $\begin{array}{c}\mathrm{g} / \mathrm{kg} \\
\mathrm{BS} \\
\end{array}$ & $\mathrm{g} / \mathrm{kg} \mathrm{CS}$ & $\begin{array}{c}\mathrm{g} / \mathrm{kg} \\
\mathrm{CS} \\
\end{array}$ & $\mathrm{mg} / \mathrm{kg}$ & $\mathrm{mg} / \mathrm{kg}$ & $\mathrm{mmol} / \mathrm{kg}$ & $\mathrm{mmol} / \mathrm{kg}$ \\
\hline \multicolumn{11}{|l|}{ Ø kamnában tánolt meggyek } \\
\hline Érdi Bőtermő integrált & 2008.VIII.2. Ujfehértó & 18,2 & 7,23 & 0,03 & 6,7 & 0,03 & 1354 & 82 & 13,9 & 0,5 \\
\hline Ujfehértói fürtös integrált & 2008.VIII.2. Ujfehértó & 19,2 & 6,33 & 0 & 5,78 & 0,12 & 1030 & 39 & 10,5 & 1,4 \\
\hline 'Kántorjánosi 3' integrált & 2008.VIII.2. Ujfehértó & 17,3 & 6,87 & 0,19 & 6,54 & 0,01 & 1269 & 32 & 12,4 & 0,5 \\
\hline Éva integrált & 2008.VIII.2. Ujfehértó & 18,5 & 8,38 & 0,12 & 7,84 & 0,12 & 1614 & 32 & 16,2 & 0,8 \\
\hline Petri integrált & 2008.VIII.2. Ujfehértó & 16,9 & 7,57 & 0,4 & 6,95 & 0,18 & 1535 & 94 & 14,8 & 1 \\
\hline Debreceni Bőtermő integrált & 2008.VIII.2. Ujfehértó & 17,9 & 7,96 & 0,27 & 7,66 & 0,58 & 1550 & 49 & 14,8 & 1 \\
\hline
\end{tabular}


4. táblázat: Almafajták méretei és tömege 2008-2009

\begin{tabular}{|c|c|c|c|c|c|}
\hline Almafajta & Dátum, termőhely & átlag & legnagyobb & legkisebb & egy szem átlag súly \\
\hline 2008 nyár, ösz & & $\mathrm{cm}$ & $\mathrm{cm}$ & $\mathrm{cm}$ & $\mathrm{g}$ \\
\hline Prima bio & 2008.VIII.21. Ujfehértó & 7,55 & 8,59 & 6,81 & 154,5 \\
\hline Prima integ & 2008.VIII.21. Ujfehértó & 7,53 & 8,71 & 6,52 & 165,2 \\
\hline Gala bio & 2008.VIII. 21. Pallag & 6,79 & 7,45 & 5,25 & 134,8 \\
\hline Gala integ & 2008.VIII. 21. Pallag & 7,31 & 8,04 & 6,05 & 167,4 \\
\hline Remo bio & 2008.IX.1. Ujfehértó & 7,29 & 8,19 & 6,02 & 158 \\
\hline Remo integrált & 2008.IX.8. Ujfehértó & 6,46 & 7,24 & 5,92 & 110 \\
\hline Remo bio & 2008.IX.29. Pallag & 6,17 & 7,30 & 4,72 & 99 \\
\hline Remo integrált & 2008.IX.29. Pallag & 7,66 & 8,91 & 6,52 & 174 \\
\hline Topáz bio & 2008.IX.25. Ujfehértó & 7,58 & 8,39 & 6,79 & 164 \\
\hline Topáz integrált & 2008.IX.29 Ujfehértó & 7,14 & 8,65 & 6,33 & 145 \\
\hline Idared bio & 2008.IX.29. Pallag & 7,74 & 9,18 & 6,81 & 185 \\
\hline Idared integrált & 2008.IX.29. Pallag & 7,88 & 8,88 & 6,22 & 196 \\
\hline \multicolumn{6}{|l|}{ 2009. január tárolt } \\
\hline Prima bio & 2008.VIII.19. Újfehértó & 7,63 & 8,27 & 7,27 & 150 \\
\hline Príma integrált & 2008.VIII.21 Újfehértó & 8,02 & 8,59 & 7,17 & 173 \\
\hline Releika bio & 2008.IX.01. Ujfehértó & 6,23 & 6,93 & 5,52 & 96 \\
\hline Releika integrált & 2008.IX.02. Újfehértó & 5,43 & 5,79 & 5,06 & 70 \\
\hline Resi bio & 2008.IX.01. Ujfehértó & 5,87 & 6,57 & 5,18 & 82 \\
\hline Resi integrált & 2008.IX.02. Újfehértó & 5,43 & 6,05 & 5,09 & 68 \\
\hline Remo bio & 2008.IX.01. Ujfehértó & 7,67 & 8,12 & 7,11 & 170 \\
\hline Remo integrált & 2008.IX.08.Újfehértó & 6,44 & 7,12 & 5,61 & 109 \\
\hline Rubinola bio & 2008.IX.03.Újfehértó & 7,77 & 8,22 & 6,77 & 174 \\
\hline Rubinola integrált & 2008.IX.08.Újfehértó & 7,12 & 7,84 & 6,38 & 133 \\
\hline Rajka bio & 2008.IX.08.Újfehértó & 7,62 & 8,26 & 7,10 & 181 \\
\hline Rajka integrált & 2008.IX.23. Újfehértó & 6,46 & 6,83 & 6,05 & 108 \\
\hline
\end{tabular}




\begin{tabular}{|c|c|c|c|c|c|}
\hline Rewena bio & 2008.IX.19. Újfehértó & 6,85 & 7,83 & 6,24 & 141 \\
\hline Rewena integrált & 2008.IX.19. Újfehértó & 6,26 & 6,88 & 5,67 & 112 \\
\hline Topaz bio & 2008.IX.25. Újfehértó & 7,58 & 8,21 & 6,52 & 166 \\
\hline Topaz integrált & 2008.X.01. Újfehértó & 7,16 & 7,88 & 6,84 & 141 \\
\hline Florina bio & 2008.IX.25. Újfehértó & 6,96 & 7,50 & 6,37 & 148 \\
\hline Florina integrált & 2008.X.1. Újfehértó & 7,56 & 8,13 & 6,84 & 181 \\
\hline Regal Prince (Gala Must) & 2008.Újfehértó & 7,40 & 8,02 & 6,95 & 182 \\
\hline Elstar & 2008.Újfehértó & 7,64 & 7,99 & 7,23 & 168 \\
\hline AS $8 / 31$ & 2008.Újfehértó & 7,59 & 7,99 & 6,95 & 174 \\
\hline Rebella & 2008.Újfehértó & 7,42 & 8,48 & 6,89 & 161 \\
\hline Jonathan M.41 & 2008.Újfehértó & 7,16 & 7,70 & 6,62 & 148 \\
\hline Sampion & 2008.Újfehértó & 8,26 & 8,86 & 7,57 & 203 \\
\hline Pinova & 2008.Újfehértó & 7,44 & 7,89 & 6,75 & 176 \\
\hline Jonagold & 2008.Újfehértó & 8,47 & 9,47 & 8,01 & 261 \\
\hline A $11 / 28$ & 2008.Újfehértó & 7,28 & 8,57 & 6,64 & 174 \\
\hline Golden Reinders & 2008.Újfehértó & 7,79 & 8,03 & 7,57 & 200 \\
\hline Cambell (Redchief) Delicious & 2008.Újfehértó & 7,23 & 7,93 & 6,84 & 179 \\
\hline Nevson (sonya) & 2008.Újfehértó & 6,97 & 7,70 & 6,43 & 165 \\
\hline Rafzubin (Rubinette) & 2008.Újfehértó & 7,18 & 7,68 & 6,35 & 155 \\
\hline Idared & 2008.Újfehértó & 8,73 & 9,24 & 8,27 & 251 \\
\hline Red Idared & 2008.Újfehértó & 8,65 & 8,94 & 8,32 & 247 \\
\hline Mutsu & 2008.Újfehértó & 9,16 & 10,11 & 8,43 & 349 \\
\hline Red Fuji & 2008.Újfehértó & 7,57 & 9,10 & 6,70 & 197 \\
\hline M 10/97 & 2008.Újfehértó & 7,68 & 8,15 & 6,99 & 201 \\
\hline Braeburn & 2008.Újfehértó & 7,87 & 8,85 & 6,99 & 220 \\
\hline Granny Smith & 2008.Újfehértó & 7,64 & 7,86 & 7,34 & 188 \\
\hline For Lady & 2008.Újfehértó & 6,85 & 7,49 & 6,39 & 148 \\
\hline Pink Lady & 2008.Újfehértó & 6,53 & 7,00 & 6,08 & 131 \\
\hline AS 10/31 & 2008.Újfehértó & 7,42 & 8,07 & 6,96 & 166 \\
\hline
\end{tabular}




\begin{tabular}{|c|c|c|c|c|c|}
\hline \multicolumn{6}{|l|}{2009 nyara } \\
\hline Prima bio 9 U9 & 2009.IX.1. Újfehértó & 6,66 & 8,05 & 5,83 & 124 \\
\hline Prima integ 9 U9 & 2009.IX.1. Újfehértó & 7,81 & 9,32 & 6,43 & 198 \\
\hline Remo bio 9 U9 & 2009.IX.1. Újfehértó & 7,10 & 7,98 & 6,45 & 154 \\
\hline Remo integrált 9 U9 & 2009.IX.1. Újfehértó & 6,19 & 6,60 & 5,65 & 102 \\
\hline Remo bio 9 P9 & 2009.IX.2. Pallag & 6,91 & 8,41 & 5,62 & 138 \\
\hline Remo integrált 9 P9 & 2009.IX.2. Pallag & 7,23 & 8,32 & 5,67 & 170 \\
\hline Topáz bio 9 U9 & 2009.IX.30.Újfehértó & 6,64 & 7,35 & 6,03 & 122 \\
\hline Topáz integ 9 U9 & 2009.IX.29.Újfehértó & 6,89 & 7,58 & 6,38 & 139 \\
\hline Idared bio 9 P9 & 2009.IX.29. Pallag & 8,65 & 9,69 & 7,82 & 284 \\
\hline Idared integ 9 P9 & 2009.IX.29. Pallag & 7,74 & 8,62 & 5,88 & 197 \\
\hline Idared integ 9 U10 & 2009.X.7. Újfehértó & 8,47 & 9,47 & 7,48 & 236 \\
\hline Red Idared integ 9 U10 & 2009.X.7. Újfehértó & 7,90 & 8,81 & 7,04 & 191 \\
\hline Rebella integrált 9 U9 & 2009.IX.1. Újfehértó & 6,34 & 6,96 & 5,83 & 111 \\
\hline Rajka integrált 9 U9 & 2009. IX.1. Ujfehértó & 6,88 & 7,47 & 5,80 & 144 \\
\hline GalaMust integrált 9 P8 & 2009.VIII.26. Pallag & 6,58 & 7,60 & 5,45 & 128 \\
\hline Florina integrált 9 U9 & 2009.IX.30. Ujfehértó & 6,89 & 8,02 & 5,91 & 148 \\
\hline Rewena integrált 9 U9 & 2009.IX.30. Ujfehértó & 6,54 & 7,38 & 5,82 & 130 \\
\hline \multicolumn{6}{|l|}{2010 január } \\
\hline Remo bio & 2009. IX.01.Újfehértó & 7,08 & 7,79 & 6,41 & 151 \\
\hline Remo integ & 2009. IX.01.Újfehértó & 6,01 & 6,63 & 5,29 & 93 \\
\hline Topáz integ & 2009. X.05.Újfehértó & 6,83 & 7,53 & 6,42 & 131 \\
\hline Topáz bio & 2009. X.05.Újfehértó & 6,92 & 7,32 & 6,62 & 136 \\
\hline Rebella integ & 2009. Újfehértó & 6,08 & 6,47 & 5,65 & 101 \\
\hline Rajka integ & 2009. IX.07.Újfehértó & 6,80 & 7,25 & 6,36 & 136 \\
\hline Rajka bio & 2009. IX.07.Újfehértó & 7,03 & 7,81 & 6,45 & 145 \\
\hline Florina integ & 2009. X.05.Újfehértó & 6,98 & 7,65 & 6,48 & 151 \\
\hline Rewena integ & 2009. IX.14.Újfehértó & 6,86 & 7,62 & 6,32 & 147 \\
\hline Idared integ & 2009. X.16.Újfehértó & 7,75 & 8,07 & 7,49 & 185 \\
\hline
\end{tabular}




\begin{tabular}{|l|l|l|l|l|c|}
\hline Red Idared & 2009. X.19.Újfehértó & 7,74 & 8,31 & 6,98 & 187 \\
\hline Releika bio & 2009. X.17. Újfehértó . & 5,88 & 6,21 & 5,32 & 86 \\
\hline Releika integ & 2009. X.07. Újfehértó & 5,22 & 5,91 & 4,91 & 63 \\
\hline Rubinola bio & 2009. VIII.27. Újfehértó & 7,15 & 7,89 & 6,81 & 132 \\
\hline Rubinola integ & 2009. VIII.27. Újfehértó & 6,46 & 6,75 & 6,12 & 111 \\
\hline Pinova & 2009. IX.25.Újfehértó & 7,12 & 7,58 & 6,48 & 172 \\
\hline Golden Reinders & 2009. IX.15.Újfehértó & 7,56 & 8,20 & 7,22 & \\
\hline M 10/97 & 2009. X.16.Újfehértó & 7,36 & 8,54 & 6,59 & \\
\hline Pink Lady & 2009. XI.02.Újfehértó & 7,17 & 7,58 & 6,75 & 174 \\
\hline Galaxi & 2009. IX.02. Újfehértó & 6,77 & 7,20 & 6,32 & 164 \\
\hline Gala Schnitzer & 2009. XI.02. Újfehértó & 6,71 & 7,12 & 6,12 & 138 \\
\hline
\end{tabular}

5. táblázat: Almafajták méretei és tömege 2010

\begin{tabular}{|c|c|c|c|c|c|c|}
\hline Fajta & Termesztés helye & évjárat & $\begin{array}{l}\text { átlag } \\
\mathrm{cm}\end{array}$ & $\begin{array}{c}\text { legnagyobb } \\
\mathrm{cm}\end{array}$ & $\begin{array}{l}\text { legkisebb } \\
\mathrm{cm}\end{array}$ & $\begin{array}{c}\text { egy szem átlag súly } \\
\text { g }\end{array}$ \\
\hline Remo bio & Ujfehértó 09.01. & 2010 jan & 7,08 & 7,79 & 6,41 & 151 \\
\hline Remo integ & Ujfehértó 09.01. & 2010 jan & 6,01 & 6,63 & 5,29 & 93 \\
\hline Topáz integ & Ujfehértó 10.05 . & 2010 jan & 6,83 & 7,53 & 6,42 & 131 \\
\hline Topáz bio & Ujfehértó 10.05 . & 2010 jan & 6,92 & 7,32 & 6,62 & 136 \\
\hline Rebella integ & Ujfehértó & 2010 jan & 6,08 & 6,47 & 5,65 & 101 \\
\hline Rajka integ & Ujfehértó 09.07. & 2010 jan & 6,80 & 7,25 & 6,36 & 136 \\
\hline Rajka bio & Ujfehértó 09.07. & 2010 jan & 7,03 & 7,81 & 6,45 & 145 \\
\hline Florina integ & Ujfehértó 10.05 . & 2010 jan & 6,98 & 7,65 & 6,48 & 151 \\
\hline Rewena integ & Ujfehértó 09.14. & 2010 jan & 6,86 & 7,62 & 6,32 & 147 \\
\hline Idared integ & Ujfehértó 10.16. & 2010 jan & 7,75 & 8,07 & 7,49 & 185 \\
\hline Red Idared & Ujfehértó 10.19 & 2010 jan & 7,74 & 8,31 & 6,98 & 187 \\
\hline Releika bio & Ujfehértó 10.07. & 2010 jan & 5,88 & 6,21 & 5,32 & 86 \\
\hline Releika integ & Ujfehértó 10.07. & 2010 jan & 5,22 & 5,91 & 4,91 & 63 \\
\hline Rubinola bio & Ujfehértó 08.27. & 2010 jan & 7,15 & 7,89 & 6,81 & 132 \\
\hline Rubinola integ & Ujfehértó 08.27. & 2010 jan & 6,46 & 6,75 & 6,12 & 111 \\
\hline
\end{tabular}




\begin{tabular}{|c|c|c|c|c|c|c|c|}
\hline Pinova & Ujfehértó 09.25. & 2010 jan & 7,12 & 7,58 & 6,48 & & 172 \\
\hline Fajta & Termesztés helye & évjárat & $\begin{array}{l}\text { átlag } \\
\mathrm{cm}\end{array}$ & $\begin{array}{l}\text { legnagyobb } \\
\mathrm{cm}\end{array}$ & $\begin{array}{l}\text { legkisebb } \\
\mathrm{cm}\end{array}$ & $\begin{array}{c}\text { egy szem átlag súly } \\
\text { g }\end{array}$ & \\
\hline Golden Reinders & Ujfehértó 09.15. & 2010 jan & 7,56 & 8,20 & 7,22 & & 183 \\
\hline Pink Lady & Ujfehértó 11.02. & 2010 jan & 7,17 & 7,58 & 6,75 & & 164 \\
\hline Galaxi & Ujfehértó 09.02. & 2010 jan & 6,77 & 7,20 & 6,32 & & 138 \\
\hline Gala Schnitzer & Ujfehértó 11.02. & 2010 jan & 6,71 & 7,12 & 6,12 & & 144 \\
\hline Prima bio & VIII.30. Újfehértó & 2010 & 6,93 & 7,75 & 6,48 & & 132 \\
\hline Prima integrált & VIII.30. Ujfehértó & 2010 & 7,17 & 8,28 & 6,49 & & 148 \\
\hline Remo bio & VIII.30. Újfehértó & 2010 & 7,05 & 7,65 & 6,52 & & 149 \\
\hline Remo integrált & VIII.30. Újfehértó & 2010 & 6,31 & 7,49 & 5,50 & & 102 \\
\hline Topáz bio & X.11. Újfehértó & 2010 & 7,23 & 7,93 & 6,31 & & 149 \\
\hline Topáz integrált & X.11. Újfehértó & 2010 & 7,61 & 8,59 & 6,55 & & 166 \\
\hline Rebella integrált & IX.20. Újfehértó & 2010 & 6,86 & 7,48 & 5,98 & & 134 \\
\hline Rajka integrált & IX.1. Újfehértó & 2010 & 7,24 & 7,89 & 6,59 & & 160 \\
\hline Florina integrált & X.11. Újfehértó & 2010 & 7,15 & 8,42 & 6,48 & & 144 \\
\hline Idared integrált & X.11. Újfehértó & 2010 & 8,05 & 8,95 & 7,19 & & 206 \\
\hline Red Idared integrált & X.11. Újfehértó & 2010 & 7,91 & 8,92 & 6,75 & & 195 \\
\hline M 5/98 integrált & VIII.30. Újfehértó & 2010 & 7,15 & 8,49 & 6,19 & & 148 \\
\hline AS 8/31 integrált & IX.20. Ujfehértó & 2010 & 7,94 & 9,11 & 6,94 & & 202 \\
\hline A11/28 integrált & X.11. Ujfehértó & 2010 & 6,94 & 7,73 & 5,94 & & 146 \\
\hline Sonya integrált & X.11. Ujfehértó & 2010 & 6,81 & 7,87 & 5,88 & & 145 \\
\hline Pink lady integrált & X.22. Újfehértó & 2010 & 6,85 & 7,39 & 6,35 & & 147 \\
\hline M10/97 integrált & X.22. Újfehértó & 2010 & 7,29 & 8,68 & 6,21 & & 161 \\
\hline
\end{tabular}


6. táblázat: Alma minták beltartalmi értékei 2008-2009

\begin{tabular}{|l|l|c|c|}
\hline Almafajta & Dátum, termőhely & Brix & $\begin{array}{c}\text { titr sav } \\
\text { pH } 8,1\end{array}$ \\
\hline 2008 nyár, ósz & & fok & g/kg CS \\
\hline Prima bio & 2008.VIII.21. Ujfehértó & 11,2 & 4,68 \\
\hline Prima integ & 2008.VIII.21. Ujfehértó & 12 & 4,68 \\
\hline Gala bio & 2008.VIII. 21. Pallag & 12,2 & 2,61 \\
\hline Gala integ & 2008.VIII. 21. Pallag & 12 & 2,35 \\
\hline Remo bio & 2008.IX.1. Ujfehértó & 14 & 7,79 \\
\hline Remo integrált & 2008.IX.8. Ujfehértó & 12,6 & 6,58 \\
\hline Remo bio & 2008.IX.29. Pallag & 15,5 & 6,7 \\
\hline Remo integrált & 2008.IX.29. Pallag & 14 & 5,4 \\
\hline Topáz bio & 2008.IX.25. Ujfehértó & 13,3 & 5,32 \\
\hline Topáz integrált & 2008.IX.29 Ujfehértó & 13,4 & 4,89 \\
\hline Idared bio & 2008.IX.29. Pallag & 12,3 & 5,06 \\
\hline Idared integrált & 2008.IX.29. Pallag & 13,6 & 6,4 \\
\hline 2009. január tárolt & & & \\
\hline Prima bio & 2008.VIII.19. Újfehértó & 9,3 & 3,16 \\
\hline Príma integrált & 2008.VIII.21 Újfehértó & 10,3 & 3,16 \\
\hline Releika bio & 2008.IX.01. Ujfehértó & 13,4 & 2,84 \\
\hline Releika integrált & 2008.IX.02. Újfehértó & 11,8 & 1,64 \\
\hline Resi bio & 2008.IX.01. Ujfehértó & 12,2 & 2,84 \\
\hline Resi integrált & 2008.IX.02. Újfehértó & 10,6 & 1,51 \\
\hline Remo bio & 2008.IX.01. Ujfehértó & 13,3 & 5,28 \\
\hline Remo integrált & 2008.IX.08.Újfehértó & 11,3 & 3,43 \\
\hline Rubinola bio & 2008.IX.03.Újfehértó & 13 & 3,78 \\
\hline Rubinola integrált & 2008.IX.08.Újfehértó & 12,5 & 2,05 \\
\hline Rajka bio & 2008.IX.08.Újfehértó & 13,6 & 2,61 \\
\hline
\end{tabular}




\begin{tabular}{|c|c|c|c|}
\hline Rajka integrált & 2008.IX.23. Újfehértó & 10,4 & 1,96 \\
\hline Almafajta & Dátum, termőhely & Brix & $\begin{array}{l}\text { titr sav } \\
\mathrm{pH} 8,1\end{array}$ \\
\hline & & fok & $\mathrm{g} / \mathrm{kg} \mathrm{CS}$ \\
\hline Rewena bio & 2008.IX.19. Újfehértó & 12,4 & 5,18 \\
\hline Rewena integrált & 2008.IX.19. Újfehértó & 12,5 & 2,77 \\
\hline Topaz bio & 2008.IX.25. Újfehértó & 12,4 & 4,89 \\
\hline Topaz integrált & 2008.X.01. Újfehértó & 11,6 & 3,21 \\
\hline Florina bio & 2008.IX.25. Újfehértó & 10,6 & 2,36 \\
\hline Florina integrált & 2008.X.1. Újfehértó & 13,2 & 1,89 \\
\hline Regal Prince (Gala Must) & 2008.Újfehértó & 12,6 & 1,58 \\
\hline Elstar & 2008.Újfehértó & 14,2 & 4,72 \\
\hline AS 8/31 & 2008.Újfehértó & 11 & 2,67 \\
\hline Rebella & 2008.Újfehértó & 12,4 & 2,39 \\
\hline Jonathan M.41 & 2008.Újfehértó & 14 & 3,25 \\
\hline Sampion & 2008.Újfehértó & 11,8 & 1,33 \\
\hline Pinova & 2008.Újfehértó & 13,6 & 1,82 \\
\hline Jonagold & 2008.Újfehértó & 15,2 & 2,17 \\
\hline A $11 / 28$ & 2008.Újfehértó & 14,8 & 3,09 \\
\hline Golden Reinders & 2008.Újfehértó & 13 & 1,83 \\
\hline Cambell (Redchief) Delicious & 2008.Újfehértó & 11,6 & 1,03 \\
\hline Nevson (Sonya) & 2008.Újfehértó & 14 & 0,79 \\
\hline Rafzubin (Rubinette) & 2008.Újfehértó & 15,2 & 3,09 \\
\hline Idared & 2008.Újfehértó & 13,9 & 5,7 \\
\hline Red Idared & 2008.Újfehértó & 15 & 4,86 \\
\hline Mutsu & 2008.Újfehértó & 13,6 & 2,84 \\
\hline Red Fuji & 2008.Újfehértó & 14,8 & 1,54 \\
\hline M 10/97 & 2008.Újfehértó & 12,5 & 4,43 \\
\hline Braeburn & 2008.Újfehértó & 14,6 & 5,19 \\
\hline
\end{tabular}




\begin{tabular}{|c|c|c|c|}
\hline Granny Smith & 2008.Újfehértó & 12,6 & 3,62 \\
\hline \multirow[t]{2}{*}{ Almafajta } & Dátum, termőhely & Brix & $\begin{array}{l}\text { titr sav } \\
\mathrm{pH} 8,1 \\
\end{array}$ \\
\hline & & fok & $\mathrm{g} / \mathrm{kg} \mathrm{CS}$ \\
\hline For Lady & 2008.Újfehértó & 12,5 & 4,21 \\
\hline Pink Lady & 2008.Újfehértó & 13,9 & 3,94 \\
\hline AS 10/31 & 2008.Újfehértó & 14,2 & 2,17 \\
\hline \multicolumn{4}{|l|}{2009 nyara } \\
\hline Prima bio & 2009.IX.1. Újfehértó & 14,8 & 4,45 \\
\hline Prima integrált & 2009.IX.1. Újfehértó & 14,5 & 5,42 \\
\hline Remo bio & 2009.IX.1. Újfehértó & 16 & 8,62 \\
\hline Remo integrált & 2009.IX.1. Újfehértó & 17,6 & 7,97 \\
\hline Remo bio & 2009.IX.2. Pallag & 15,5 & 9,5 \\
\hline Remo integrált & 2009.IX.2. Pallag & 15,9 & 5,42 \\
\hline Topáz bio & 2009.IX.30.Újfehértó & 14,6 & 7,94 \\
\hline Topáz integrált & 2009.IX.29. Újfehértó & 14,5 & 5,56 \\
\hline Idared bio & 2009.IX.29. Pallag & 15,8 & 3,82 \\
\hline Idared integrált & 2009.IX.29. Pallag & 14,7 & 4,55 \\
\hline Idared integrált & 2009.X.7. Újfehértó & 13,2 & 5,78 \\
\hline Red Idared integrált & 2009.X.7. Újfehértó & 13,8 & 5,56 \\
\hline Rebella integrált & 2009.IX.1. Újfehértó & 15,2 & 6,03 \\
\hline Rajka integrált & 2009. IX.1. Ujfehértó & 16,1 & 4,77 \\
\hline GalaMust integrált & 2009.VIII.26. Pallag & 14,6 & 2,16 \\
\hline Florina integrált & 2009.IX.30. Újfehértó & 15,4 & 3,08 \\
\hline Rewena integrált & 2009.IX.30. Újfehértó & 13,7 & 5,05 \\
\hline \multicolumn{4}{|l|}{ 2010. január } \\
\hline Remo bio & 2009. IX.01.Újfehértó & 15,2 & 4,75 \\
\hline Remo integrált & 2009. IX.01.Újfehértó & 16 & 3,58 \\
\hline Topáz integrált & 2009. X.05.Újfehértó & 15,4 & 3,78 \\
\hline
\end{tabular}




\begin{tabular}{|l|l|c|c|}
\hline Topáz bio & 2009. X.05.Újfehértó & 14,9 & 5,05 \\
\hline Almafajta & Dátum, termöhely & Brix & $\begin{array}{c}\text { titr sav } \\
\text { pH } 8,1\end{array}$ \\
\hline & & fok & g/kg CS \\
\hline Rebella integrált & 2009. Újfehértó & 15,1 & 4,3 \\
\hline Rajka integrált & 2009. IX.07.Újfehértó & 15,6 & 1,82 \\
\hline Rajka bio & 2009. IX.07.Újfehértó & 16 & 3,4 \\
\hline Florina integrált & 2009. X.05.Újfehértó & 15,8 & 2,46 \\
\hline Rewena integrált & 2009. IX.14. Újfehértó & 11,9 & 3,67 \\
\hline Idared integrált & 2009. X.16. Újfehértó & 13,1 & 2,66 \\
\hline Red Idared integrált & 2009. X.19. Újfehértó & 13 & 1,94 \\
\hline Releika bio & 2009. X.17. Újfehértó. & 14,2 & 2,21 \\
\hline Releika integrált & 2009. X.07. Újfehértó & 15,4 & 2,16 \\
\hline Rubinola bio & 2009. VIII.27. Újfehértó & 15,1 & 2 \\
\hline Rubinola integrált & 2009. VIII.27. Újfehértó & 14,8 & 1,63 \\
\hline Pinova integrált & 2009. IX.25. Újfehértó & 18,6 & 4,52 \\
\hline Golden Reinders integrált & 2009. IX.15. Újfehértó & 14 & 1,45 \\
\hline M 10/97 integrált & 2009. X.16. Újfehértó & 15,9 & 4,78 \\
\hline Pink Lady integrált & 2009. XI.02.Újfehértó & 14,1 & 4,59 \\
\hline Galaxi integrált & 2009. IX.02. Újfehértó & 13,8 & 1,42 \\
\hline Gala Schnitzer integrált & 2009. XI.02. Újfehértó & 14 & 1,29 \\
\hline
\end{tabular}


7. táblázat: Alma minták beltartalmi értékei 2010

\begin{tabular}{|c|c|c|c|c|c|}
\hline \multirow[t]{2}{*}{ Fajta } & Termesztés helye & évjárat & Brix & titr sav pH7 & titr sav pH 8,1 \\
\hline & & & fok & $\mathrm{g} / \mathrm{kg} \mathrm{BS}$ & $\mathrm{g} / \mathrm{kg} \mathrm{CS}$ \\
\hline Remo bio & Ujfehértó 09.01. & 2010 jan & 15,2 & 5,2 & 4,75 \\
\hline Remo integ & Ujfehértó 09.01. & 2010 jan & 16 & 3,87 & 3,58 \\
\hline Topáz integ & Ujfehértó 10.05. & 2010 jan & 15,4 & 4,21 & 3,78 \\
\hline Topáz bio & Ujfehértó 10.05. & 2010 jan & 14,9 & 5,69 & 5,05 \\
\hline Rebella integ & Ujfehértó & 2010 jan & 15,1 & 4,8 & 4,3 \\
\hline Rajka integ & Ujfehértó 09.07. & 2010 jan & 15,6 & 1,92 & 1,82 \\
\hline Rajka bio & Ujfehértó 09.07. & 2010 jan & 16 & 3,76 & 3,4 \\
\hline Florina integ & Ujfehértó 10.05. & 2010 jan & 15,8 & 2,65 & 2,46 \\
\hline Rewena integ & Ujfehértó 09.14. & 2010 jan & 11,9 & 3,97 & 3,67 \\
\hline Idared integ & Ujfehértó 10.16. & 2010 jan & 13,1 & 2,91 & 2,66 \\
\hline Red Idared & Ujfehértó 10.19 & 2010 jan & 13 & 2,04 & 1,94 \\
\hline Releika bio & Ujfehértó 10.07. & 2010 jan & 14,2 & 2,39 & 2,21 \\
\hline Releika integ & Ujfehértó 10.07. & 2010 jan & 15,4 & 2,33 & 2,16 \\
\hline Rubinola bio & Ujfehértó 08.27. & 2010 jan & 15,1 & 2,15 & 2 \\
\hline Rubinola integ & Ujfehértó 08.27. & 2010 jan & 14,8 & 1,74 & 1,63 \\
\hline Pinova & Ujfehértó 09.25. & 2010 jan & 18,6 & 4,91 & 4,52 \\
\hline Golden Reinders & Ujfehértó 09.15. & 2010 jan & 14 & 1,56 & 1,45 \\
\hline M 10/97 & Ujfehértó 10.16. & 2010 jan & 15,9 & 5,35 & 4,78 \\
\hline Pink Lady & Ujfehértó 11.02. & 2010 jan & 14,1 & 5,13 & 4,59 \\
\hline Galaxi & Ujfehértó 09.02. & 2010 jan & 13,8 & 1,43 & 1,42 \\
\hline Gala Schnitzer & Ujfehértó 11.02. & 2010 jan & 14 & 1,33 & 1,29 \\
\hline Prima bio & VIII.30. Újfehértó & 2010 & 11,5 & 6,56 & 5,85 \\
\hline Prima integrált & VIII.30. Ujfehértó & 2010 & 11,8 & 5,01 & 4,48 \\
\hline Remo bio & VIII.30. Újfehértó & 2010 & 13,5 & 11,5 & 10,05 \\
\hline Remo integrált & VIII.30. Újfehértó & 2010 & 13,6 & 10,23 & 8,98 \\
\hline Topáz bio & X.11. Újfehértó & 2010 & 13 & 6,51 & 5,7 \\
\hline Topáz integrált & X.11. Újfehértó & 2010 & 13,8 & 9,03 & 7,87 \\
\hline Rebella integrált & IX.20. Újfehértó & 2010 & 12 & 5,57 & 4,89 \\
\hline Rajka integrált & IX.1. Újfehértó & 2010 & 12,2 & 4,95 & 4,38 \\
\hline
\end{tabular}




\begin{tabular}{|c|c|c|c|c|c|}
\hline Florina integrált & X.11. Újfehértó & 2010 & 12,2 & 2,8 & 2,54 \\
\hline Rewena integrált & X.11. Újfehértó & 2010 & 12,2 & 2,8 & 2,54 \\
\hline Idared integrált & X.11. Újfehértó & 2010 & 12,5 & 5,47 & 4,8 \\
\hline \multirow[t]{2}{*}{ Fajta } & Termesztés helye & évjárat & Brix & titr sav pH7 & titr sav pH 8,1 \\
\hline & & & fok & $\mathrm{g} / \mathrm{kg} \mathrm{BS}$ & $\mathrm{g} / \mathrm{kg} \mathrm{CS}$ \\
\hline Red Idared integrált & X.11. Újfehértó & 2010 & 13,4 & 6,04 & 5,3 \\
\hline M 5/98 integrált & VIII.30. Újfehértó & 2010 & 13,4 & 7 & 6,34 \\
\hline AS 8/31 integrált & IX.20. Ujfehértó & 2010 & 12,1 & 6,71 & 5,91 \\
\hline A11/28 integrált & X.11. Ujfehértó & 2010 & 14,5 & 7,58 & 6,64 \\
\hline Sonya integrált & X.11. Ujfehértó & 2010 & 14,8 & 3,28 & 2,96 \\
\hline Pink lady integrált & X.22. Újfehértó & 2010 & 13,8 & 7,14 & 6,26 \\
\hline M10/97 integrált & X.22. Újfehértó & 2010 & 14 & 8,26 & 7,23 \\
\hline
\end{tabular}


8. táblázat: Körték méretei és súlya 2008-2009-2010

\begin{tabular}{|c|c|c|c|c|c|c|c|c|}
\hline körte & dátum, termőhely & átlag & legnagyobb & legkisebb & átlag & legnagyobb & legkisebb & $\begin{array}{c}\text { egy szem } \\
\text { átlag } \\
\text { súlya } \\
\end{array}$ \\
\hline & & szélte & szélte & szélte & hossza & hossza & hossza & $\mathrm{g}$ \\
\hline & & $\mathrm{cm}$ & $\mathrm{cm}$ & $\mathrm{cm}$ & $\mathrm{cm}$ & $\mathrm{cm}$ & $\mathrm{cm}$ & \\
\hline Vilmos körte & 2008.VIII.1. Nagykanizsa & 6,60 & 7,32 & 5,81 & 8,43 & 9,85 & 7,38 & 175 \\
\hline Bosc kobak & 2008.IX.2. Nagykanizsa & 7,31 & 8,68 & 6,53 & 10,51 & 11,95 & 8,52 & 258 \\
\hline Packham's Triumph & 2008.IX.3. Nagykanizsa & 7,04 & 8,11 & 5,95 & 8,45 & 9,98 & 7,32 & 199 \\
\hline Conference & 2008.VIII.30. Nagykanizsa & 6,57 & 7,54 & 5,58 & 9,61 & 11,80 & 8,15 & 184 \\
\hline Fétel apát & 2008.IX.2. Nagykanizsa & 6,74 & 7,45 & 5,95 & 11,40 & 13,90 & 9,22 & 218 \\
\hline Vilmos körte & 2009. IX.1. Nagykanizsa & 6,72 & 7,75 & 5,68 & 8,65 & 11,20 & 7,12 & 190 \\
\hline Bosc kobak & 2009.IX.2. Nagykanizsa & 7,50 & 8,62 & 5,95 & 12,19 & 13,55 & 10,03 & 275 \\
\hline Packham's Triumph & 2009.X.1. Nagykanizsa & 7,96 & 8,95 & 6,92 & 9,72 & 11,78 & 8,04 & 279 \\
\hline Conference & 2009.X.1. Nagykanizsa & 6,67 & 7,39 & 6,03 & 10,24 & 11,55 & 8,95 & 190 \\
\hline Fétel apát & 2009.X.1. Nagykanizsa & 7,61 & 9,22 & 6,55 & 12,50 & 15,05 & 9,95 & 301 \\
\hline Concorde & 2009.X.1. Nagykanizsa & 6,99 & 8,15 & 5,29 & 8,90 & 10,35 & 6,62 & 214 \\
\hline Vilmos körte & 2010.X.2. Nagykanizsa & 6,8 & 7,7 & 5,5 & 9 & 10,2 & 7,4 & 201 \\
\hline Bosc kobak & 2010.X.1. Nagykanizsa & 7,2 & 8,2 & 6,1 & 9,6 & 11,1 & 8,4 & 213 \\
\hline Packham's Triumph & 2010.X.1. Nagykanizsa & 7,5 & 8,3 & 6,7 & 8,4 & 9,7 & 7,1 & 229 \\
\hline Conference & 2010.X.1. Nagykanizsa & 7 & 7,6 & 6,4 & 12,3 & 9,5 & 7,3 & 218 \\
\hline Fétel apát & 2010.X.1. Nagykanizsa & 6,6 & 7,5 & 6 & 11 & 15,1 & 8 & 212 \\
\hline
\end{tabular}


9. táblázat: Körte beltartalmi értékei, tárolása 2008-2009-2010

\begin{tabular}{|c|c|c|c|}
\hline körte & dátum, termőhely & Brix & $\begin{array}{l}\text { titr sav } \\
\mathrm{pH} 8,1\end{array}$ \\
\hline 2008 & & fok & $\mathrm{g} / \mathrm{kg} \mathrm{CS}$ \\
\hline Vilmos körte & 2008.VIII.1. Nagykanizsa & 14,9 & 1,85 \\
\hline Bosc kobak & 2008.IX.2. Nagykanizsa & 16,1 & 1,38 \\
\hline Packham's Triumph & 2008.IX.3. Nagykanizsa & 14,8 & 1,48 \\
\hline Conference & 2008.VIII.30. Nagykanizsa & 17,4 & 1,26 \\
\hline Fétel apát & 2008.IX.2. Nagykanizsa & 15 & 1,44 \\
\hline \multicolumn{4}{|l|}{ Körte, kitárolva november 10 -én } \\
\hline Bosc kobak & 2008.IX.2. Nagykanizsa & 15,2 & 1,49 \\
\hline Packham's Triumph & 2008.IX.3. Nagykanizsa & 14 & 1,49 \\
\hline Conference & 2008.VIII..30. Nagykanizsa & 16,9 & 1,41 \\
\hline Fétel apát & 2008.IX.2. Nagykanizsa & 14,8 & 1,8 \\
\hline \multicolumn{4}{|l|}{ Körte, kitárolva január 12-én } \\
\hline Bosc kobak & 2008.IX.2. Nagykanizsa & 14,3 & 1,63 \\
\hline Packham's Triumph & 2008.IX.3. Nagykanizsa & 12,9 & 1,45 \\
\hline Conference & 2008.VIII..30. Nagykanizsa & 16,9 & 1,13 \\
\hline Fétel apát & 2008.IX.2. Nagykanizsa & 14,2 & 1,48 \\
\hline \multicolumn{4}{|l|}{2009} \\
\hline Vilmos körte & 2009. IX.1. Nagykanizsa & 15,3 & 3,34 \\
\hline Bosc kobak & 2009.IX.2. Nagykanizsa & 14,3 & 1,34 \\
\hline Packham's Triumph Nagykanizsa & 2009.X.1. Nagykanizsa & 15 & 1,67 \\
\hline Conference & 2009.X.1. Nagykanizsa & 15 & 1,1 \\
\hline Fétel apát & 2009.X.1. Nagykanizsa & 13,8 & 2,01 \\
\hline Concorde & 2009.X.1. Nagykanizsa & 14,6 & 2,53 \\
\hline
\end{tabular}




\begin{tabular}{|l|l|c|c|}
\hline körte & dátum, termöhely & Brix & $\begin{array}{c}\text { titr sav } \\
\mathrm{pH} 8,1\end{array}$ \\
\hline $\mathbf{2 0 1 0}$ & & fok & $\mathrm{g} / \mathrm{kg} \mathrm{CS}$ \\
\hline Vilmos körte & 2010.VIII.5. Nagykanizsa & 13,1 & 2,52 \\
\hline Bosc kobak & 2010.IX.4. Nagykanizsa & 15,4 & 2,27 \\
\hline Packham's Triumph & 2010.IX.3. Nagykanizsa & 13,2 & 1,29 \\
\hline Conference & 2010.VIII.30. Nagykanizsa & 15,9 & 1,63 \\
\hline Fétel apát & 2010.X.2. Nagykanizsa & 13,5 & 2,08 \\
\hline
\end{tabular}


10. táblázat: Integrált és bio termesztésböl származó meggyfajták antocianin összetétele és mennyisége (Szüretelés dátuma: 2009. 06. 29.)

Fajta Debreceni bőtermő Újfehértói fürtös 'Kántorjánosi 3'

\section{Integrált}

$\left(\mathrm{mg} \mathrm{kg}^{-1}\right)$

$\begin{array}{lrrr}\text { cy-glu-rut } & 148,6 \pm 35,5 & 238,4 \pm 47,8 & 152,9 \pm 12,4 \\ \text { cy-glu } & 8,6 \pm 2,8 & 12,1 \pm 4,1 & 7,9 \pm 1,2 \\ \text { cy-rut } & 86,9 \pm 38,5 & 110,8 \pm 22,5 & 79,5 \pm 86,0 \\ \text { pe-rut } & 1,5 \pm 0,3 & 2,8 \pm 0,0 & 1,5 \pm 0,3 \\ \text { Ismeretlen } & 11,0 \pm 3,3 & 13,0 \pm 0,7 & 12,7 \pm 1,1 \\ 5 & & 1,1 \pm 0,0 & \\ \text { Ismeretlen } & 0,4 \pm 0,4 & & 0,6 \pm 0,5 \\ 6 & & & 0,2 \pm 0,3 \\ \text { Ismeretlen } & & & \\ 7 & & 378,1 \pm 73,8 & 253,5 \pm 23,4 \\ \text { összesen } & 257,0 \pm 80,0 & & \end{array}$

Bio

$\left(\mathrm{mg} \mathrm{kg}^{-1}\right)$

$\begin{array}{lrrr}\text { cy-glu-rut } & 143,3 \pm 20,5 & 272,7 \pm 41,7 & 203,1 \pm 10,79 \\ \text { cy-glu } & 8,1 \pm 1,0 & 13,8 \pm 2,5 & 11,4 \pm 6,3 \\ \text { cy-rut } & 76,7 \pm 10,5 & 118,5 \pm 13,4 & 105,1 \pm 62,2 \\ \text { pe-rut } & 1,2 \pm 0,2 & 2,5 \pm 0,0 & 2,2 \pm 0,5 \\ \text { Ismeretlen } & 10,6 \pm 0,6 & 13,4 \pm 0,8 & 11,7 \pm 5,1 \\ 5 & & & \\ \text { Ismeretlen } & 0,3 \pm 0,3 & 1,1 \pm 0,2 & 0,8 \pm 0,2 \\ 6 & & & \\ \text { Ismeretlen } & & & 334,4 \pm 57,0 \\ 7 & & 422,0 \pm 57,0 & \\ \text { összesen } & 240,2 \pm 31,4 & & \end{array}$

Röviditések: cy-glu-rut: Cianidin-glukozil-rutinosid, cy-glu: Cianidin-glukozid, cy-glu: Cianidinrutinosid, pe-rut: Peonidin-rutinosid 
11. táblázat: Integrált és bio termesztésből származó meggyfajtákban azonosított polifenol vegyületek mennyisége

\section{Integrált}

Komponensek

galluszsav

neoklorogénsav

catechin

klorogénsav

Kvercetin-glikozidok

galluszsav

neoklorogénsav

catechin

klorogénsav

Kvercetin-glikozidok

galluszsav

neoklorogénsav

catechin

klorogénsav

Kvercetin-glikozidok $m g \mathrm{~kg}^{-1}$

\section{'Kántorjánosi 3'}

$$
1,3 \pm 0,1
$$

$471,5 \pm 53,9$

$10,1 \pm 2,1$

$62,2 \pm 5,2$

$16,0 \pm 2,1$

\section{Debreceni bőtermő}

$\begin{array}{cr}1,0 \pm 0,1 & 0,6 \pm 0,3 \\ 532,0 \pm 52,9 & 560,3 \pm 74,9 \\ 4,4 \pm 3,1 & 4,4 \pm 0,5 \\ 89,2 \pm 7,5 & 91,8 \pm 13,4 \\ 30,4 \pm 3,6 & 23,4 \pm 1,3 \\ \text { Újfehértói fürtös } & \\ 0,8 \pm 0,1 & 0,6 \pm 0,1 \\ 510,3 \pm 64,1 & 591,4 \pm 59,0 \\ 5,4 \pm 2,4 & 4,2 \pm 0,3 \\ 83,5 \pm 14,1 & 91,6 \pm 12,6 \\ 27,1 \pm 0,2 & 26,4 \pm 3,1\end{array}$

$502,9 \pm 112,1$

$8,0 \pm 3,5$

$65,4 \pm 28,7$

$20,9 \pm 3,6$

\section{Bio}

$\mathrm{mg} \mathrm{kg}^{-1}$

Kvercetin-glikozidok kalibrációja alapján számoltuk. 
12. táblázat: Meggy minták mikrobiológiai eredménye 2008-2009-2010

\begin{tabular}{|c|c|c|c|c|c|c|}
\hline Fajta & $\begin{array}{c}\text { Termesztési } \\
\text { mód }\end{array}$ & Évjárat & Termesztés helye & $\begin{array}{c}\text { Aerob összcsíraszám } \\
\left(\text { tke/cm }^{2}\right) \operatorname{logN}\end{array}$ & $\begin{array}{l}\text { Penész szám } \\
\left(\text { tke/cm }^{2}\right) \log N\end{array}$ & $\begin{array}{l}\text { Élesztő szám } \\
\left(\text { tke/cm² }^{2}\right) \log N\end{array}$ \\
\hline Csengödi & Integrált & 2008 & Újfehértó & 2,92 & 2,73 & 1,88 \\
\hline $\begin{array}{l}\text { Debreceni } \\
\text { bőtermö }\end{array}$ & Bio & 2008 & Nyíregyháza & 3,53 & 1,88 & 1,66 \\
\hline $\begin{array}{l}\text { Debreceni } \\
\text { bőtermö }\end{array}$ & Integrált & 2008 & Újfehértó & 3,23 & 1,85 & 0 \\
\hline Érdi bőtermő & Bio & 2008 & Nyíregyháza & 5,86 & 5,80 & 4,86 \\
\hline Érdi bőtermő & Integrált & 2008 & Újfehértó & 3,47 & 4,17 & 2,57 \\
\hline Éva & Integrált & 2008 & Újfehértó & 1,93 & 3,63 & 3,04 \\
\hline $\begin{array}{l}\text { 'Kántorjánosi } \\
\text { 3' }\end{array}$ & Bio & 2008 & Nyíregyháza & 4,15 & 5,41 & 2,74 \\
\hline $\begin{array}{l}\text { 'Kántorjánosi } \\
3 \text { ' }\end{array}$ & Integrált & 2008 & Újfehértó & 2,23 & 3,76 & 3 \\
\hline Petri & Integrált & 2008 & Újfehértó & 2,83 & 3,7 & 3,23 \\
\hline $\begin{array}{l}\text { Újfehértói } \\
\text { fürtös }\end{array}$ & Bio & 2008 & Nyíregyháza & 4,32 & 3,43 & 3,80 \\
\hline $\begin{array}{l}\text { Újfehértói } \\
\text { fürtös }\end{array}$ & Integrált & 2008 & Újfehértó & 3,95 & 4,73 & 3,68 \\
\hline Érdi bőtermő & Integrált & 2008 & Újfehértó & 4,08 & 3,08 & 0 \\
\hline $\begin{array}{l}\text { Debreceni } \\
\text { bőtermő }\end{array}$ & Integrált & 2008 & Úffehértó & 3,5 & 3,38 & 0 \\
\hline Éva & Integrált & 2008 & Újfehértó & 2,57 & 3,32 & 2,34 \\
\hline Petri & Integrált & 2008 & Újfehértó & 3,53 & 3,2 & 3,3 \\
\hline $\begin{array}{l}\text { Újfehértói } \\
\text { fürtös }\end{array}$ & Integrált & 2008 & Újfehértó & 5 & 5 & 2,78 \\
\hline $\begin{array}{l}\text { 'Kántorjánosi } \\
3 \text { ' }\end{array}$ & Integrált & 2008 & Újfehértó & 3,52 & 3,68 & 2,17 \\
\hline $\mathrm{VN}-1$ & Integrált & 2009 & Újfehértó & 3,63 & 3,2 & 2,72 \\
\hline $\mathrm{VN}-4$ & Integrált & 2009 & Újfehértó & 3,67 & 3,26 & 3,45 \\
\hline VN-7 & Integrált & 2009 & Újfehértó & 3,45 & 2,34 & 2,86 \\
\hline Csengődi & Integrált & 2009 & Újfehértó & 3,75 & 3,15 & 2,34 \\
\hline Érdi bőtermő & Integrált & 2009 & Újfehértó & 3,75 & 5,93 & 5,76 \\
\hline Pipacs & Integrált & 2009 & Újfehértó & 4,41 & 4,23 & 0 \\
\hline „D” & Integrált & 2009 & Újfehértó & 6,15 & 3,45 & 0 \\
\hline Debreceni & Integrált & 2009 & Újfehértó & 3,41 & 3,23 & 0 \\
\hline Éva & Integrált & 2009 & Újfehértó & 4,23 & 4,32 & 0 \\
\hline
\end{tabular}




\begin{tabular}{|c|c|c|c|c|c|c|}
\hline $\begin{array}{l}\text { Újjfehértói } \\
\text { fürtös }\end{array}$ & Integrált & 2009 & Újfehértó & 5,23 & 3,75 & 2,97 \\
\hline Petri & Integrált & 2009 & Újfehértó & 5,32 & 3,15 & 3,76 \\
\hline $\begin{array}{l}\text { 'Kántorjánosi } \\
3 \text { ' }\end{array}$ & Integrált & 2009 & Újfehértó & 4,38 & 2,94 & 3,94 \\
\hline $\begin{array}{l}\text { 'Kántorjánosi } \\
3 \text { ' }\end{array}$ & Integrált & 2009 & Újfehértó & 4,28 & 3,96 & 3,5 \\
\hline $\begin{array}{l}\text { Újfehértói } \\
\text { fürtös }\end{array}$ & Integrált & 2009 & Újfehértó & 3,99 & 3,88 & 2,88 \\
\hline $\begin{array}{l}\text { Debreceni } \\
\text { bőtermö }\end{array}$ & Integrált & 2009 & Újfehértó & 4,1 & 3,87 & 3,34 \\
\hline $\begin{array}{l}\text { Debreceni } \\
\text { bötermő }\end{array}$ & Bio & 2009 & Nyíregyháza & 4,1 & 3,9 & 2,73 \\
\hline $\begin{array}{l}\text { Újfehértói } \\
\text { fürtös }\end{array}$ & Bio & 2009 & Nyíregyháza & 5,86 & 4,18 & 3,32 \\
\hline $\begin{array}{l}\text { 'Kántorjánosi } \\
3 \text { ' }\end{array}$ & Bio & 2009 & Nyíregyháza & 4,84 & 5,3 & 3,3 \\
\hline $\begin{array}{l}\text { 'Kántorjánosi } \\
\text { 3' }\end{array}$ & Integrált & 2009 & Újfehértó & 0,98 & 2,76 & 0 \\
\hline $\begin{array}{l}\text { Újfehértói } \\
\text { fürtös }\end{array}$ & Integrált & 2009 & Újfehértó & 3,47 & 3,17 & 0 \\
\hline $\begin{array}{l}\text { Debreceni } \\
\text { bőternő }\end{array}$ & Integrált & 2009 & Újfehértó & 2,87 & 2,48 & 0 \\
\hline $\begin{array}{l}\text { Debreceni } \\
\text { bőtermő }\end{array}$ & Bio & 2009 & Nyíregyháza & 3,98 & 0 & 0 \\
\hline $\begin{array}{l}\text { Újfehértói } \\
\text { fürtös }\end{array}$ & Bio & 2009 & Nyíregyháza & 3,8 & 3,85 & 4,11 \\
\hline $\begin{array}{l}\text { 'Kántorjánosi } \\
3 \text { ' }\end{array}$ & Bio & 2009 & Nyíregyháza & 5,92 & 3,68 & 0 \\
\hline VN-4 & Integrált & 2010 & Újfehértó & 4,41 & 2 & 1,2 \\
\hline VN-7 & Integrált & 2010 & Lövőpetri & 4,63 & 1,81 & 4,53 \\
\hline $\mathrm{VN}-1$ & Integrált & 2010 & Újfehértó & 4,56 & 1,56 & 1,1 \\
\hline $\mathrm{VN}-7 / 2$ & Integrált & 2010 & Lövőpetri & 4,23 & 4,25 & 5 \\
\hline Cigány 59 & Integrált & 2010 & Újfehértó & 6,28 & 1,24 & 6,45 \\
\hline Cigány 7 & Integrált & 2010 & Újfehértó & 4,36 & 2 & 5,76 \\
\hline Érdi bőtermő & Bio & 2010 & Kabalás & 1,4 & 3,2 & 3,53 \\
\hline Érdi bőtermő & Integrált & 2010 & Újfehértó & 5,28 & 1,74 & 4,11 \\
\hline $\mathrm{VN}-4 / 2$ & Integrált & 2010 & Újfehértó & 4,34 & 1,6 & 2,82 \\
\hline Oblacsinszka & Integrált & 2010 & Újfehértó & 2,41 & 1,4 & 1,1 \\
\hline Csengődi & Integrált & 2010 & Újfehértó & 3,92 & 1,5 & 3,3 \\
\hline Piacról hozott & Integrált & 2010 & Újfehértó & 3,36 & 1,8 & 2,36 \\
\hline
\end{tabular}




\begin{tabular}{|c|c|c|c|c|c|c|}
\hline $\begin{array}{l}\text { Debreceni } \\
\text { bőtermö }\end{array}$ & Integrált & 2010 & Újfehértó & 1,35 & 2,70 & 1,14 \\
\hline $\begin{array}{l}\text { Újfehértói } \\
\text { fürtös }\end{array}$ & Integrált & 2010 & Újfehértó & 1,40 & 1,34 & 1,12 \\
\hline $\begin{array}{l}\text { 'Kántorjánosi } \\
3 \text { ' }\end{array}$ & Integrált & 2010 & Újfehértó & 3,36 & 3,58 & 1,6 \\
\hline Pándi 279 & Integrált & 2010 & Újfehértó & 3,6 & 3,41 & 1,7 \\
\hline $\begin{array}{l}\text { Debreceni } \\
\text { bőtermő }\end{array}$ & Bio & 2010 & Kabalás & 3,49 & 2 & 2 \\
\hline $\begin{array}{l}\text { Újfehértói } \\
\text { fürtös }\end{array}$ & Bio & 2010 & Kabalás & 3,41 & 2,38 & 2 \\
\hline $\begin{array}{l}\text { 'Kántorjánosi } \\
3 \text { ' }\end{array}$ & Bio & 2010 & Kabalás & 2 & 2 & 1,3 \\
\hline Éva & Integrált & 2010 & Újfehértó & 1,15 & 2 & 2,38 \\
\hline Petri & Integrált & 2010 & Újfehértó & 2,3 & 2,08 & 2,39 \\
\hline
\end{tabular}

13. táblázat: Cseresznye minták mikrobiológiai eredménye 2008-2009-2010

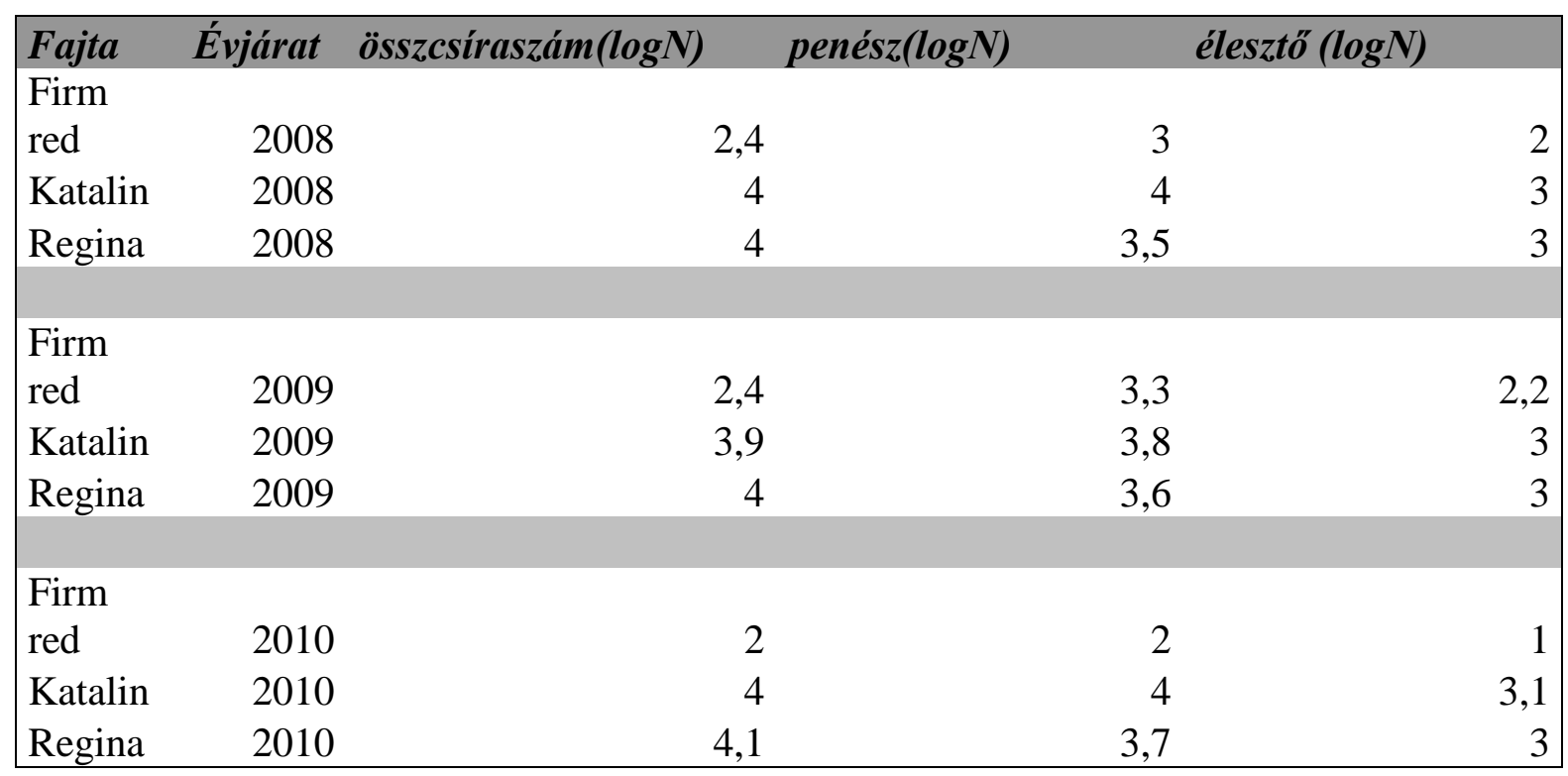

14. táblázat: Alma minták mikrobiológiai eredménye 2008-2009-2010

\begin{tabular}{|l|l|l|l|l|l|l|}
\hline \multicolumn{1}{|c|}{ Fajta } & $\begin{array}{c}\text { Termesztés } \\
\text { módja }\end{array}$ & \multicolumn{1}{|c|}{ Évjárat } & Termesztés helye & $\begin{array}{c}\text { Aerob összcsíraszám } \\
\text { (tke/cm2) lgN }\end{array}$ & $\begin{array}{c}\text { Penész } \\
(\text { tke/cm2) lgN } \\
(\text { tke/cm2) lgN }\end{array}$ \\
\hline $\begin{array}{l}\text { Gála Must } \\
\text { Pallag }\end{array}$ & Integrált & 2008 & Újfehértó & 2,64 & 3,08 \\
\hline $\begin{array}{l}\text { Gála Must } \\
\text { Pallag }\end{array}$ & Bio & 2008 & Pallag & 3,97 & 0 \\
\hline Prima & Integrált & 2008 & Újfehértó & 5,67 & 3,94 \\
\hline
\end{tabular}




\begin{tabular}{|c|c|c|c|c|c|c|}
\hline Prima & Bio & 2008 & Pallag & 4,76 & 2,61 & 0 \\
\hline Gála & Bio & 2008 & Pallag & 4,47 & 3,43 & 2,8 \\
\hline Remo & Integrált & 2008 & Újfehértó & 3 & 3 & 2,43 \\
\hline Remo & Bio & 2008 & Pallag & 1,39 & 3,71 & 0 \\
\hline Topáz & Integrált & 2008 & Újfehértó & 5,38 & 4,79 & 2,53 \\
\hline Topáz & Bio & 2008 & Pallag & 5,2 & 3,89 & 2,44 \\
\hline Idared & Integrált & 2008 & Újfehértó & 5,32 & 3,64 & 3,64 \\
\hline Idared & Bio & 2008 & Pallag & 5,44 & 2,44 & 3,88 \\
\hline Remo & Integrált & 2008 & Újfehértó & 4,25 & 3,23 & 3,2 \\
\hline Remo & Bio & 2008 & Pallag & 4,38 & 4 & 2,71 \\
\hline Prima & Bio & 2009 & Pallag & 4,69 & 4,23 & 0 \\
\hline Prima & Integrált & 2009 & Újfehértó & 4,77 & 2,8 & 0 \\
\hline Releika & Bio & 2009 & Pallag & 4,11 & 2,81 & 0 \\
\hline Releika & Integrált & 2009 & Újfehértó & 3,38 & 2,44 & 0 \\
\hline Resi & Bio & 2009 & Pallag & 4,88 & 3,11 & 3,44 \\
\hline Resi & Integrált & 2009 & Újfehértó & 3,94 & 2,08 & 0 \\
\hline Remo & Bio & 2009 & Pallag & 4,76 & 2,84 & 1,84 \\
\hline Remo & Integrált & 2009 & Újfehértó & 3,86 & 2,08 & 0 \\
\hline Rubinola & Bio & 2009 & Pallag & 4,41 & 2,69 & 1,3 \\
\hline Rubinola & Integrált & 2009 & Újfehértó & 4 & 2,72 & 2 \\
\hline Rajka & Bio & 2009 & Pallag & 3,65 & 3,3 & 2,61 \\
\hline Rajka & Integrált & 2009 & Újfehértó & 3,44 & 3,44 & 2,44 \\
\hline Rewena & Bio & 2009 & Pallag & 3,6 & 4,23 & 3,53 \\
\hline Rewena & Integrált & 2009 & Újfehértó & 3 & 3,44 & 2,36 \\
\hline Topáz & Bio & 2009 & Pallag & 3,69 & 5,44 & 1,96 \\
\hline Topáz & Integrált & 2009 & Újfehértó & 3,43 & 3,11 & 2,17 \\
\hline Florina & Integrált & 2009 & Újfehértó & 2,46 & 2,79 & 1,99 \\
\hline Prima & Integrált & 2009 & Újfehértó & 2,3 & 2 & 1,2 \\
\hline Rebella & Integrált & 2009 & Újfehértó & 2,58 & 2 & 1,87 \\
\hline Prima & Bio & 2009 & Pallag & 2,8 & 1,9 & 2 \\
\hline Remo & Bio & 2009 & Pallag & 2,15 & 2 & 2,23 \\
\hline Gála & Integrált & 2009 & Újfehértó & 2,65 & 1,84 & 1,68 \\
\hline Remo & Integrált & 2009 & Újfehértó & 3,2 & 2,7 & 2 \\
\hline
\end{tabular}




\begin{tabular}{|c|c|c|c|c|c|c|}
\hline Rajka & Integrált & 2009 & Újfehértó & 3,23 & 2,62 & 2 \\
\hline Idared Pallag & Bio & 2009 & Pallag & 3,11 & 2,75 & 2,11 \\
\hline Florina & Integrált & 2009 & Újfehértó & 3,99 & 2,8 & 2,91 \\
\hline Idared Pallag & Integrált & 2009 & Újfehértó & 3,41 & 2,95 & 2,56 \\
\hline Rewena & Integrált & 2009 & Újfehértó & 3,28 & 3,15 & 2,48 \\
\hline Topáz & Integrált & 2009 & Újfehértó & 3,08 & 4,23 & 2,57 \\
\hline Remo Pallag & Integrált & 2009 & Újfehértó & 9,3 & 2,85 & 2,49 \\
\hline Remo & Bio & 2009 & Pallag & 3,45 & 2,74 & 2,34 \\
\hline Topáz & Bio & 2009 & Pallag & 3,46 & 2,99 & 2,21 \\
\hline Red Idared & Integrált & 2009 & Újfehértó & 3,46 & 2,98 & 1,95 \\
\hline Idared & Integrált & 2009 & Újfehértó & 3,25 & 2,93 & 2,83 \\
\hline Prima & Bio & 2010 & Pallag & 3,49 & 2,5 & 1 \\
\hline Prima & Integrált & 2010 & Újfehértó & 4,94 & 2,8 & 1,7 \\
\hline Remo & Bio & 2010 & Pallag & 3,61 & 2,5 & 1 \\
\hline Remo & Integrált & 2010 & Újfehértó & 3,63 & 2,3 & 1 \\
\hline M 5/98 & Integrált & 2010 & Újfehértó & 3,66 & 2,7 & 1,53 \\
\hline Red Idared & Integrált & 2010 & Újfehértó & 4 & 3,1 & 1,3 \\
\hline Topáz & Integrált & 2010 & Újfehértó & 4,9 & 2,17 & 1 \\
\hline A $11 / 28$ & Integrált & 2010 & Újfehértó & 3,4 & 2 & 1 \\
\hline Sonya & Integrált & 2010 & Újfehértó & 5,48 & 2,2 & 1 \\
\hline Rewena & Integrált & 2010 & Újfehértó & \begin{tabular}{|l|}
4,7 \\
\end{tabular} & 2,3 & 1 \\
\hline Florina & Integrált & 2010 & Újfehértó & 4,69 & 2,4 & 1,3 \\
\hline Idared & Integrált & 2010 & Újfehértó & 4 & 2,6 & 1 \\
\hline Topáz & Bio & 2010 & Pallag & 4,6 & 2,5 & 3,75 \\
\hline Pink Lady & integrált & 2010 & Újfehértó & 4,11 & 3,2 & 4,38 \\
\hline M 10/97 & Integrált & 2010 & Újfehértó & 4,25 & 2,45 & 3,71 \\
\hline
\end{tabular}

15. táblázat: Körte minták mikrobiológiai eredménye 2008-2009-2010

\begin{tabular}{|c|c|c|c|c|c|c|}
\hline Fajta & $\begin{array}{l}\text { Termeszté } \\
\text { s módja }\end{array}$ & Évjárat & $\begin{array}{c}\text { Termesztés } \\
\text { helye }\end{array}$ & $\begin{array}{c}\text { Aerob } \\
\text { összcsíraszám } \\
(\text { tke/cm2) } \operatorname{logN}\end{array}$ & $\begin{array}{c}\text { Penész } \\
(\text { tke/cm2) } \log N\end{array}$ & $\begin{array}{c}\text { Élesztö } \\
(\text { tke/cm2) } \\
\log \mathbf{N}\end{array}$ \\
\hline Bosc Kobak & Integrált & 2008 & Nagykanizsa & 3,28 & 2,15 & 1,78 \\
\hline Conference & Integrált & 2008 & Nagykanizsa & 3,7 & 4,95 & 4,47 \\
\hline
\end{tabular}




\begin{tabular}{|l|l|l|l|l|l|l|}
\hline Fétel Apát & Integrált & 2008 & Nagykanizsa & 3,46 & 0 & 0 \\
\hline $\begin{array}{l}\text { Packham's } \\
\text { Triumph }\end{array}$ & Integrált & 2008 & Nagykanizsa & 3,3 & 0 & 0 \\
\hline Bosc Kobak & Integrált & 2009 & Nagykanizsa & 4,41 & 2,11 & 3,17 \\
\hline Fétel Apát & Integrált & 2009 & Nagykanizsa & 3,2 & 1,9 & 3,41 \\
\hline Conference & Integrált & 2009 & Nagykanizsa & 4,23 & 3,25 & 0 \\
\hline $\begin{array}{l}\text { Packham's } \\
\text { Triumph }\end{array}$ & Integrált & 2009 & Nagykanizsa & 2,86 & 1,66 & 3 \\
\hline Bosc Kobak & Integrált & 2009 & Nagykanizsa & 2,6 & 2,3 & 2,6 \\
\hline Conference & Integrált & 2009 & Nagykanizsa & 3 & 2,08 & 2,55 \\
\hline $\begin{array}{l}\text { Packham's } \\
\text { Triumph }\end{array}$ & Integrált & 2009 & Nagykanizsa & 3,08 & 2,51 & 3,11 \\
\hline Fétel Apát & Integrált & 2009 & Nagykanizsa & 2,7 & 2,2 & 2,91 \\
\hline Concorde & Integrált & 2009 & Nagykanizsa & 3,6 & 2,68 & 3,5 \\
\hline Vilmos körte & Integrált & 2009 & Nagykanizsa & 3,36 & 2,3 & 0 \\
\hline
\end{tabular}

16. táblázat: meggy és cseresznye ökológiai termesztés során használt védekezési formák

\begin{tabular}{|l|l|}
\hline Idöszak & Ökológiai növényvédelem módszerei \\
\hline $\begin{array}{l}\text { Nyugalmi } \\
\text { állapotban, } \\
\text { rügypattan } \\
\text { ás elött }\end{array}$ & $\begin{array}{l}\text { Fák ápolása és tisztogatása, moníliás és glöospóriumos gyümölcsmúmiák eltávolítása. } \\
\text { Fa-sebkezelö alkalmazása (BIOCERA) } \\
\text { Lemosópermetezés réztartalmú hatóanyaggal az áttelelt élősködök ellen. } \\
\text { Levéltetvek, pajzstetvek várható inváziója ellen a réz mellé poliszulfidkén is } \\
\text { alkalmazható (NEVIKÉN). }\end{array}$ \\
\hline $\begin{array}{l}\text { Rügypatta } \\
\text { nás és } \\
\text { egérfüles } \\
\text { állapot }\end{array}$ & $\begin{array}{l}\text { Védekezés a monília és levéllikasztó betegségek ellen réztartalmú szerrel. } \\
\text { Bacillus thuringiensis alkalmazása sodrómoly és araszolóhernyó ellen. }\end{array}$ \\
\hline $\begin{array}{l}\text { Fehérbimb } \\
\text { ós } \\
\text { állapottól } \\
\text { sziromhull } \\
\text { ásig }\end{array}$ & $\begin{array}{l}\text { Felkészülés a meggy monília elleni védekezésére, melyre az ökológiai védekezésben a } \\
\text { védekezö eszközök palettája még igencsak gyér. Használható az elemi kén 0,2-0,4\%-os } \\
\text { töménységú oldata. } \\
\text { Bacillus thuringiensis alkalmazása sodrómoly és araszolóhernyó ellen. } \\
\text { Levéltetü kolóniák ellen különféle olajok (BIOLA). } \\
\text { Virágzáskor a cseresznyelégy ellen sárga rovarfogó lapok kihelyezése. } \\
\text { Fontos a levéltetü ragadozók betelepítése (katicabogarak, fátyolkák) a hazai cseresznye- }\end{array}$ \\
\hline
\end{tabular}




\begin{tabular}{|l|l|}
\hline & és meggy ültetvényekbe. \\
\hline $\begin{array}{l}\text { Gyümölcs } \\
\text { kötődéstöl } \\
\text { betakarítás } \\
\text { ig }\end{array}$ & $\begin{array}{l}\text { Monília ellen védekezni kell egészen betakarításig elemi kén és híg réztartalmú } \\
\text { készítményekkel. } \\
\text { Bacillus thuringiensis alkalmazása sodrómoly és araszolóhernyó ellen. } \\
\text { Atka és pajzstetű ellen különféle olajok nyári hígításban (BIOLA). }\end{array}$ \\
\hline $\begin{array}{l}\text { Betakarítás } \\
\text { utáni } \\
\text { növényvéd } \\
\text { elem }\end{array}$ & $\begin{array}{l}\text { További ápolás, mivel a lombhullásig még 2,5-3 hónap telik el. } \\
\text { Blumeriella és levéllikasztó betegség ellen réztartalmú lemosó permetezés javasolt. }\end{array}$ \\
$\begin{array}{l}\text { Levéltetvek, pajzstetvek ellen a réz mellé poliszulfidkén is alkalmazható (NEVIKÉN). } \\
\text { Füstösszárnyú levéldarázs ellen BIOSOL vagy KÁLISZAPPAN. } \\
\text { Kéregmoly ellen Bacillus thuringiensis készítmények alkalmazása. }\end{array}$ \\
\hline $\begin{array}{l}\text { Tárolási } \\
\text { időszak }\end{array}$ & $\begin{array}{l}\text { Gyümölcsök híg réztartalmú oldatba mártása a tároláskor jelentkező gombás betegségek } \\
\text { (Monilia, Penicillium, Botrytis) elkerülésére. }\end{array}$ \\
\hline
\end{tabular}

(Holb, 2005 nyomán)

17. táblázat: alma és körte ökológiai termesztés során használt védekezési formák

\begin{tabular}{|c|c|}
\hline Időszak & Ökológiai növényvédelem módszerei \\
\hline $\begin{array}{l}\text { Nyugalmi } \\
\text { állapotban, } \\
\text { rügypattanás } \\
\text { elött }\end{array}$ & $\begin{array}{l}\text { Faápolás, tisztogatás, lombkorona tisztítás, metszéssel a fertőzött ágak eltávolítása. } \\
\text { Fa-sebkezelő (BIOCERA) alkalmazása, lemosó permetezés a tetvek ellen különféle } \\
\text { olajokkal (BIOLA) illetve 10-15\%-os mészkén lével, réztartalmú készítmények } \\
\text { használata a tüzelhalás ellen. }\end{array}$ \\
\hline Rügypattanás & $\begin{array}{l}\text { Lisztharmat, tetvek elleni védekezés (NEVIKÉN, poliszulfid kén + vazelinolaj). } \\
\text { Varrasodás és tűzelhalás ellen rézkénporral való permetezés }\end{array}$ \\
\hline $\begin{array}{l}\text { Zöldbimbós és } \\
\text { piros/fehér } \\
\text { bimbós állapot }\end{array}$ & $\begin{array}{l}\text { Ventúria elleni védelemben még a réztartalmú készítmények alkalmazhatóak } \\
\text { jelentősebb fitotoxicitási veszély nélkül } \\
\text { Tetvek elleni védekezés olajos készítményekkel (BIOLA). Körtelevélbolha ellen } \\
\text { olaj és mészkénlé kombinációjának alkalmazása } \\
\text { Kártevők elleni védekezés (sodrómoly): azadirachtin vagy Bacillus thuringiensis } \\
\text { tartalmú szerekkel (PRONATURA és BACTUCID) }\end{array}$ \\
\hline $\begin{array}{l}\text { Virágzástól } \\
\text { sziromhullásig }\end{array}$ & $\begin{array}{l}\text { Venturiás varrasodásnak az aszkospóra szóródási csúcsa, ezért fontos a védekezés } \\
\text { kizárólag } 0,2-0,4 \% \text {-os kéntartalmú szerekkel. } \\
\text { Lisztharmat ellen a kéntartalmú szerek tapadásának fokozására javasolt nedvesítő }\end{array}$ \\
\hline
\end{tabular}




\begin{tabular}{|c|c|}
\hline & $\begin{array}{l}\text { szerek permetléhez keverése (KÁLISZAPPAN). } \\
\text { Tüzelhalás elleni védelem fontossága, külföldön már engedélyezett a Pseudomonas } \\
\text { fluorescens törzset tartalmazó készítmény. } \\
\text { Pajzstetvek ellen áprilisban fogólapok kihelyezése (1. ábra). }\end{array}$ \\
\hline $\begin{array}{l}\text { Gyümölcskötő } \\
\text { déstől } \\
\text { betakarításig }\end{array}$ & $\begin{array}{l}\text { Ventúriás varrasodás elleni további védekezés elemi kén vagy nyári higítású } \\
\text { mészkénlé alkalmazásával. } \\
\text { Tüzelhalás elleni védekezés, ha magas a páratartalom. } \\
\text { Körte esetében az amerikai fehér medvelepke (szövölepke) hernyófészkeinek } \\
\text { levágása és elégetése. Június közepétöl körtelevélbolha írtása szappan alapú } \\
\text { készítménnyel. } \\
\text { Almamoly elleni védekezés ferromonos légtértelítési módszerrel (hímek } \\
\text { megtévesztése mesterséges nőstény illatanyaggal) párologtató diszpenzerek } \\
\text { kihelyezésével (2. ábra), illetve víruskészítményekkel, olajokkal. Június közepétől } \\
\text { almamolyhernyók összegyüjtésére alkalamas hernyófogó hullámpapír-övek } \\
\text { kihelyezése a fák törzsére. } \\
\text { Levélaknázó molyok ellen Bacillus thuringiensis készítmények. } \\
\text { Levéltetvek ellen különféle növényi olajokkal való lemosás. } \\
\text { Cserebogárfajok pajorjai ellen különböző baktérium tartalmú (pl.: Bacillus popiliae) } \\
\text { biopreparátumok. }\end{array}$ \\
\hline $\begin{array}{l}\text { Betakarítás } \\
\text { utáni } \\
\text { növényvédele } \\
\text { m }\end{array}$ & $\begin{array}{l}\text { Réz-és olajtartalmú zárópermetezés. } \\
\text { A réz a tűzelhalás, nektáriás ágrákosodás, monília és a ventúriás varasodás ellen, } \\
\text { míg az olajos lemosás a levéltetvek, atkák ellen. }\end{array}$ \\
\hline $\begin{array}{l}\text { Tárolási } \\
\text { időszak }\end{array}$ & $\begin{array}{l}\text { Gyümölcsök híg réztartalmú oldatba mártása a tároláskor jelentkezö gombás } \\
\text { betegségek (Monilia, Penicillium, Botrytis) elkerülésére. }\end{array}$ \\
\hline
\end{tabular}

(Holb, 2005 nyomán) 


\section{M3. Fényképek}

1. kép: Almaminták: Prima és GalaMust fajta bio és integrált pár

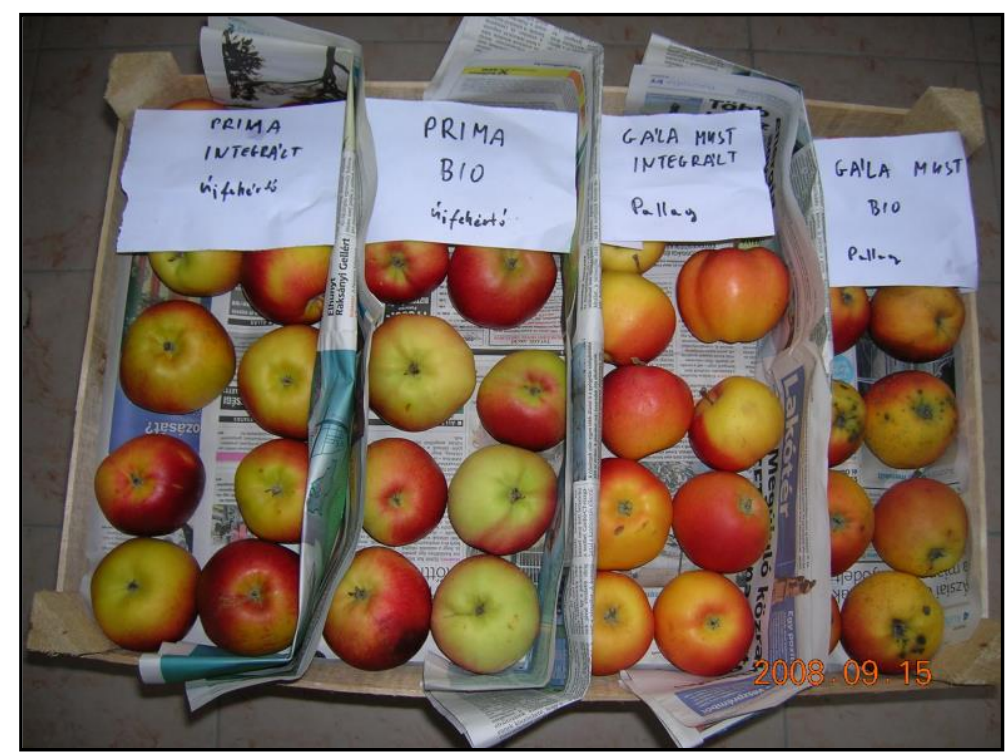

\section{2. kép: Almaminták: Remo fajta bio és integrált pár}

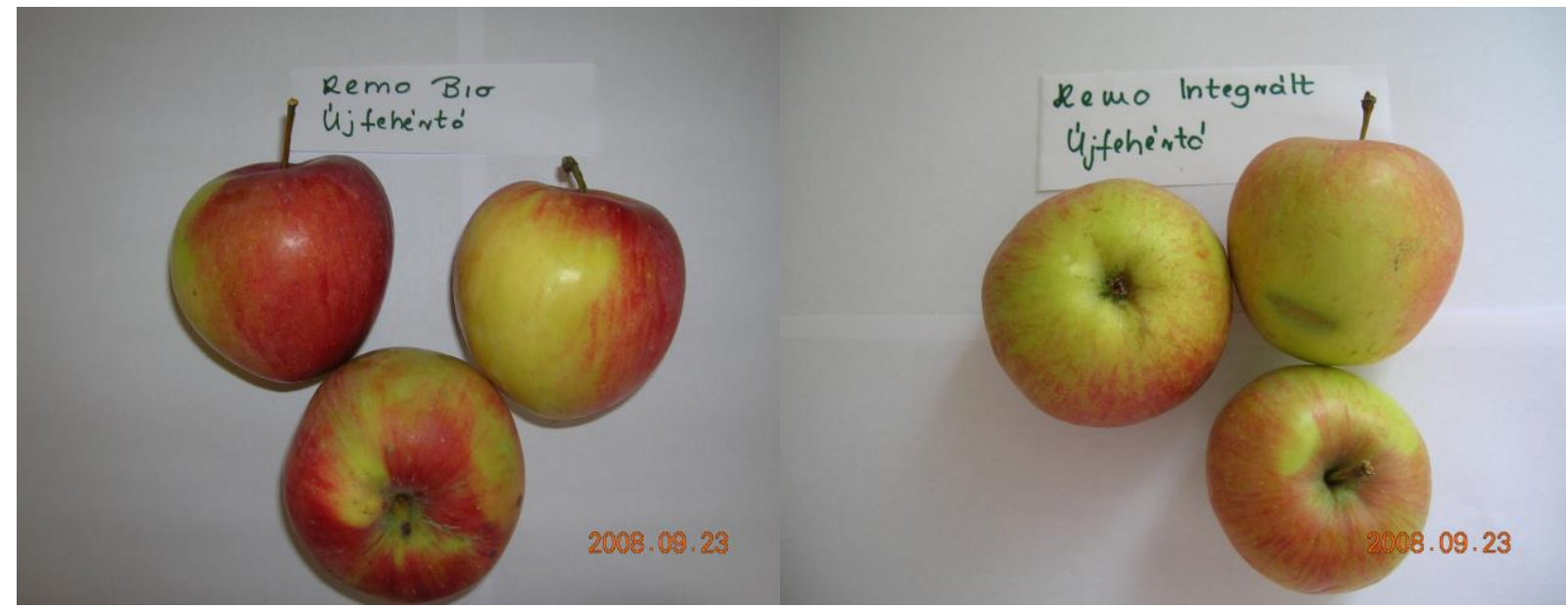

3. kép: Almaminták: Topáz fajta bio és integrált pár

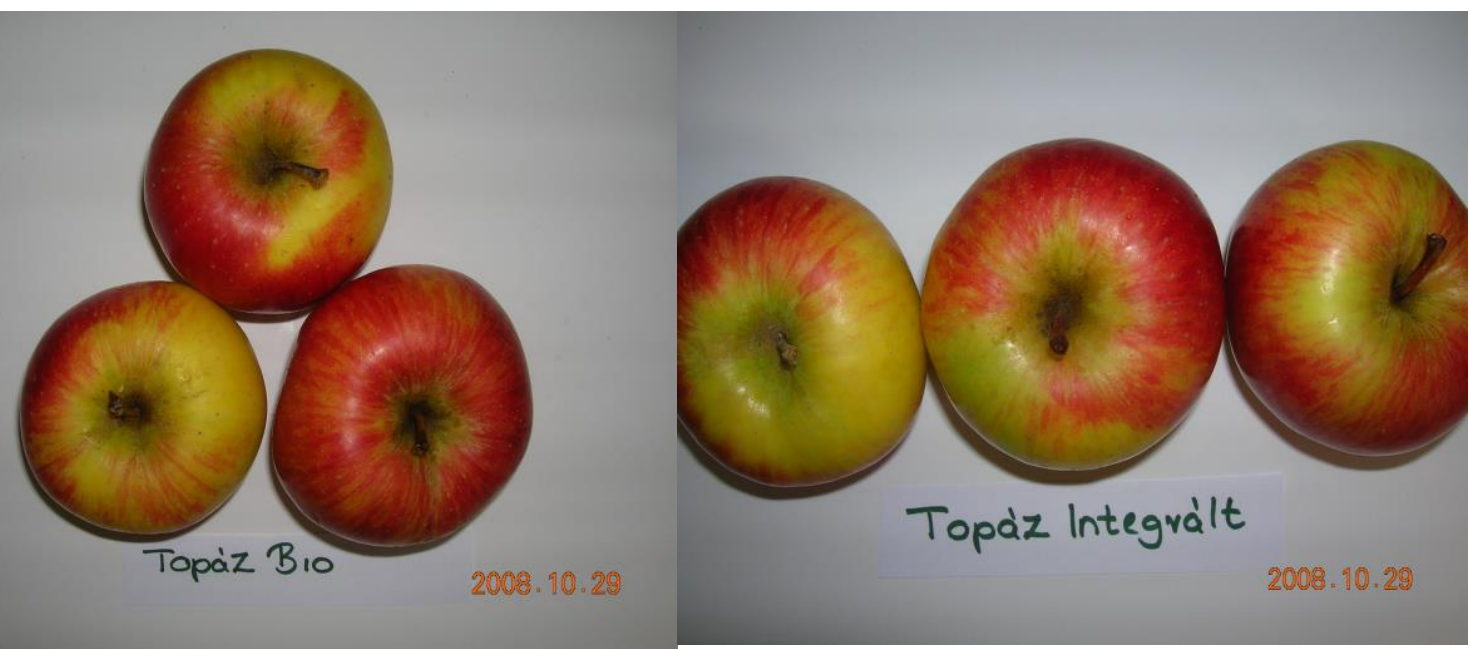




\section{4. kép: Almaminták: Idared fajta bio és integrált pár}

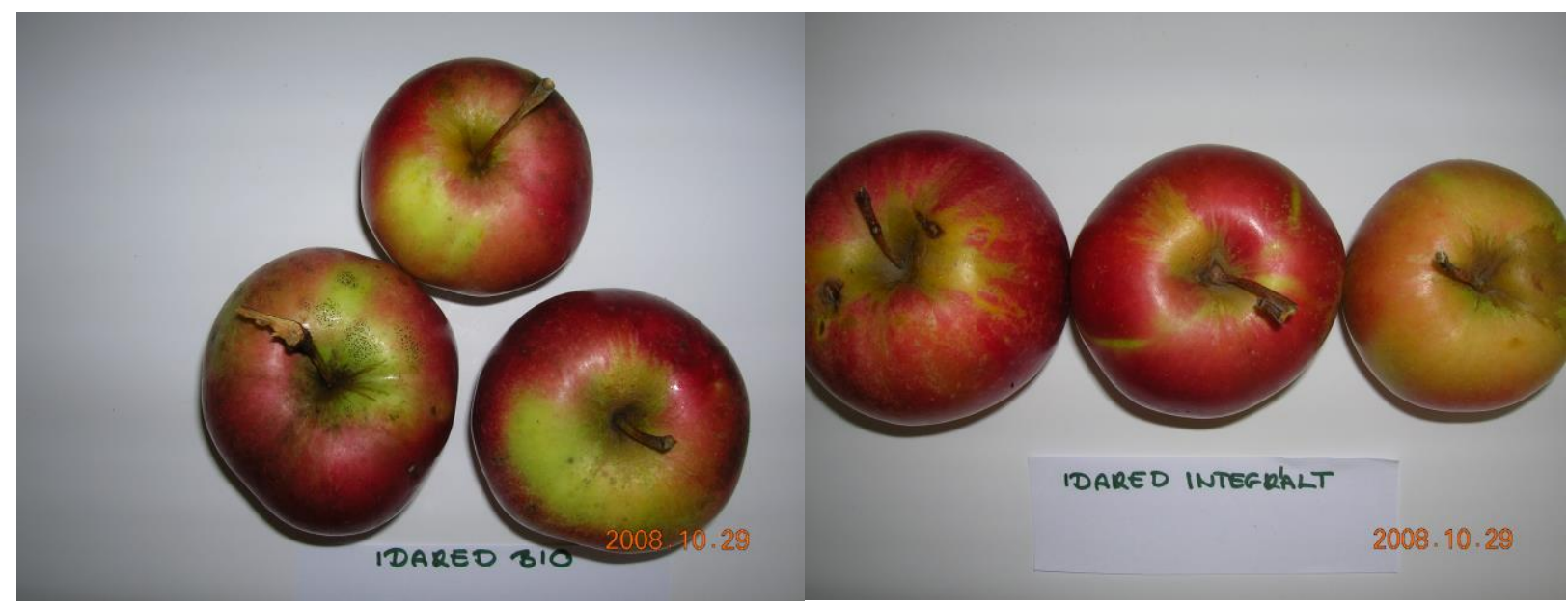

5. kép: Almaminták: Remo fajta bio és integrált pár

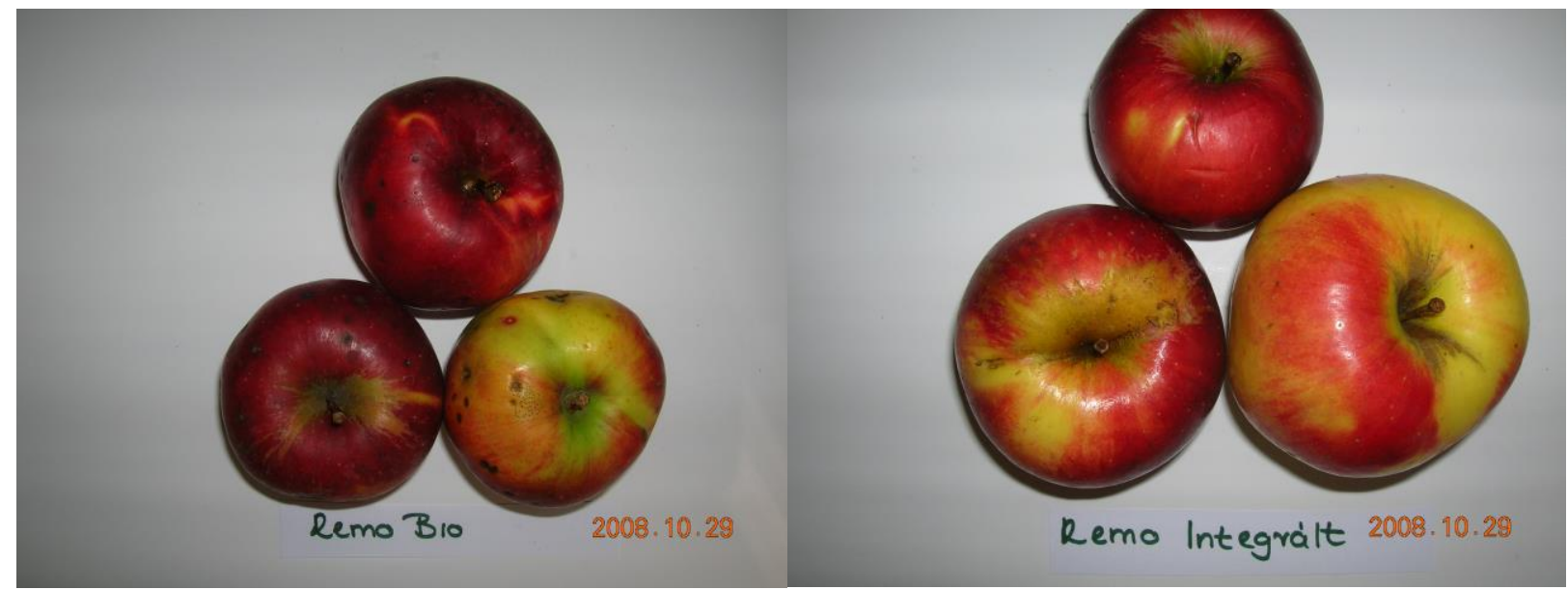

6. kép: Fétel apát és Bosc kobak integrált termesztésü körték

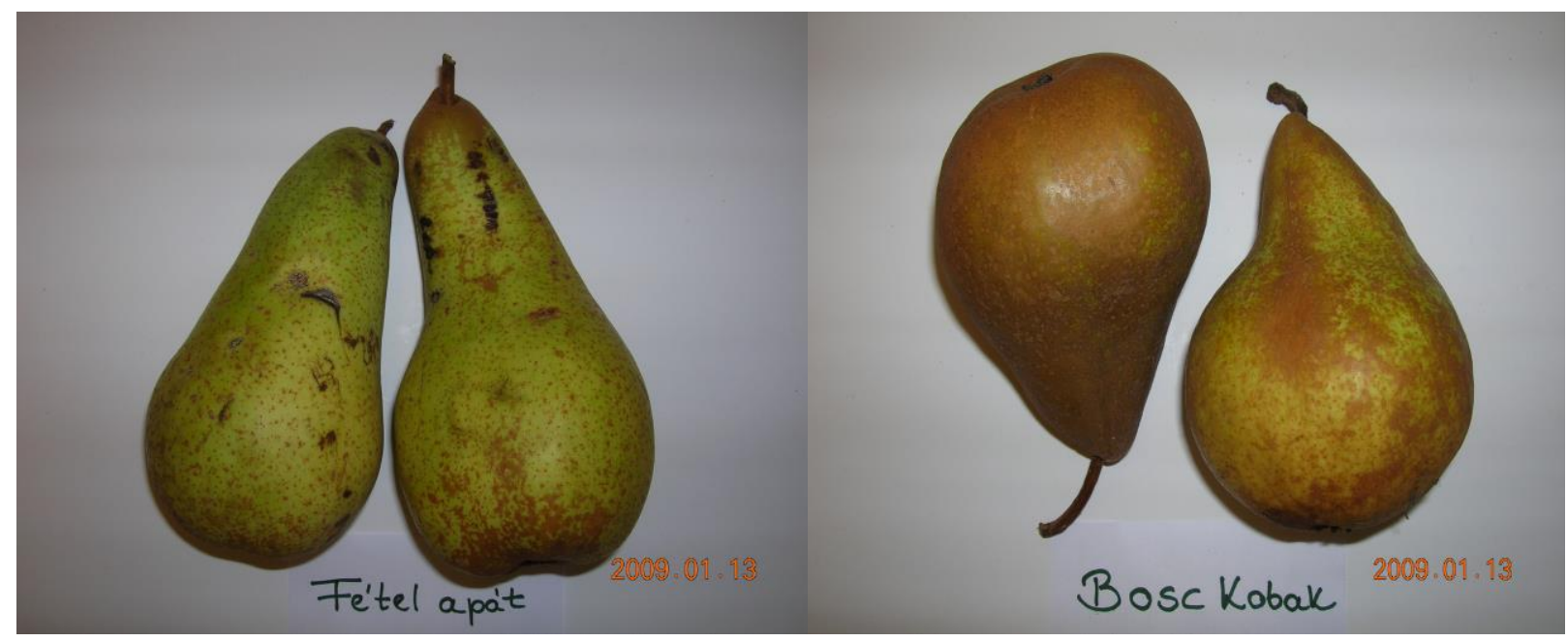


7. kép: Conference és Packham's Triumph integrált termesztésü körték
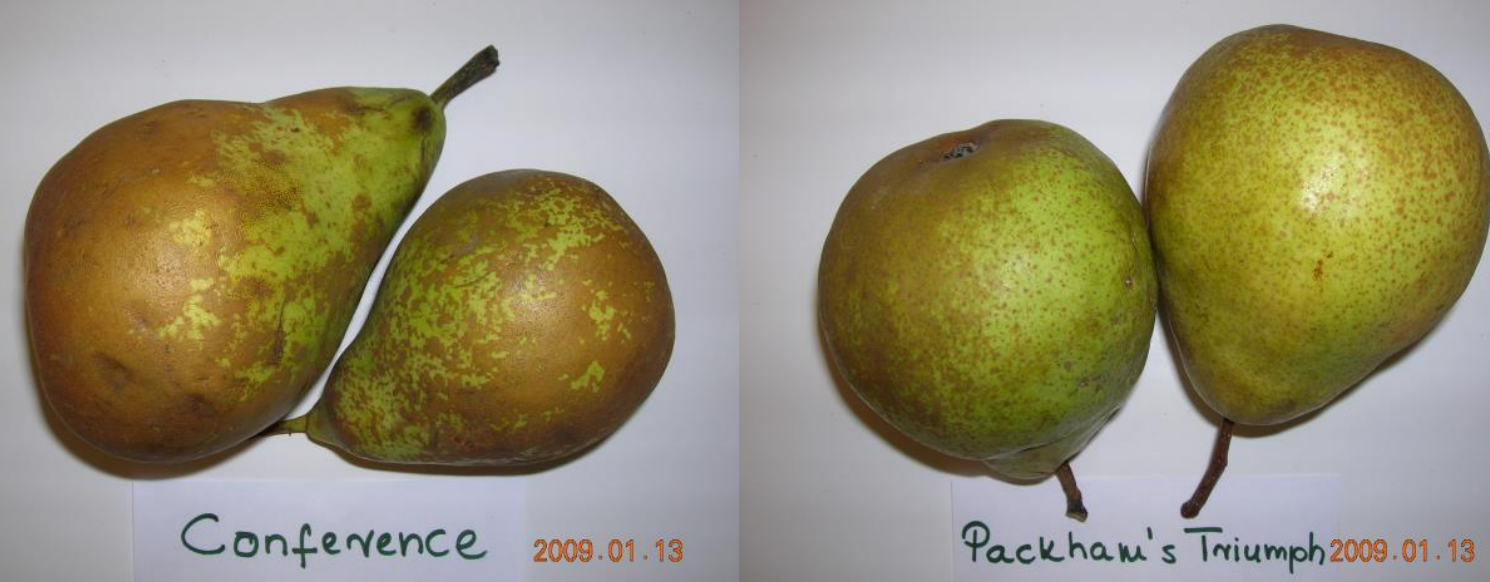

8. kép: Élesztő-és penész szám meghatározás - rózsazsín és fehér élesztő telepek a Petricsészén

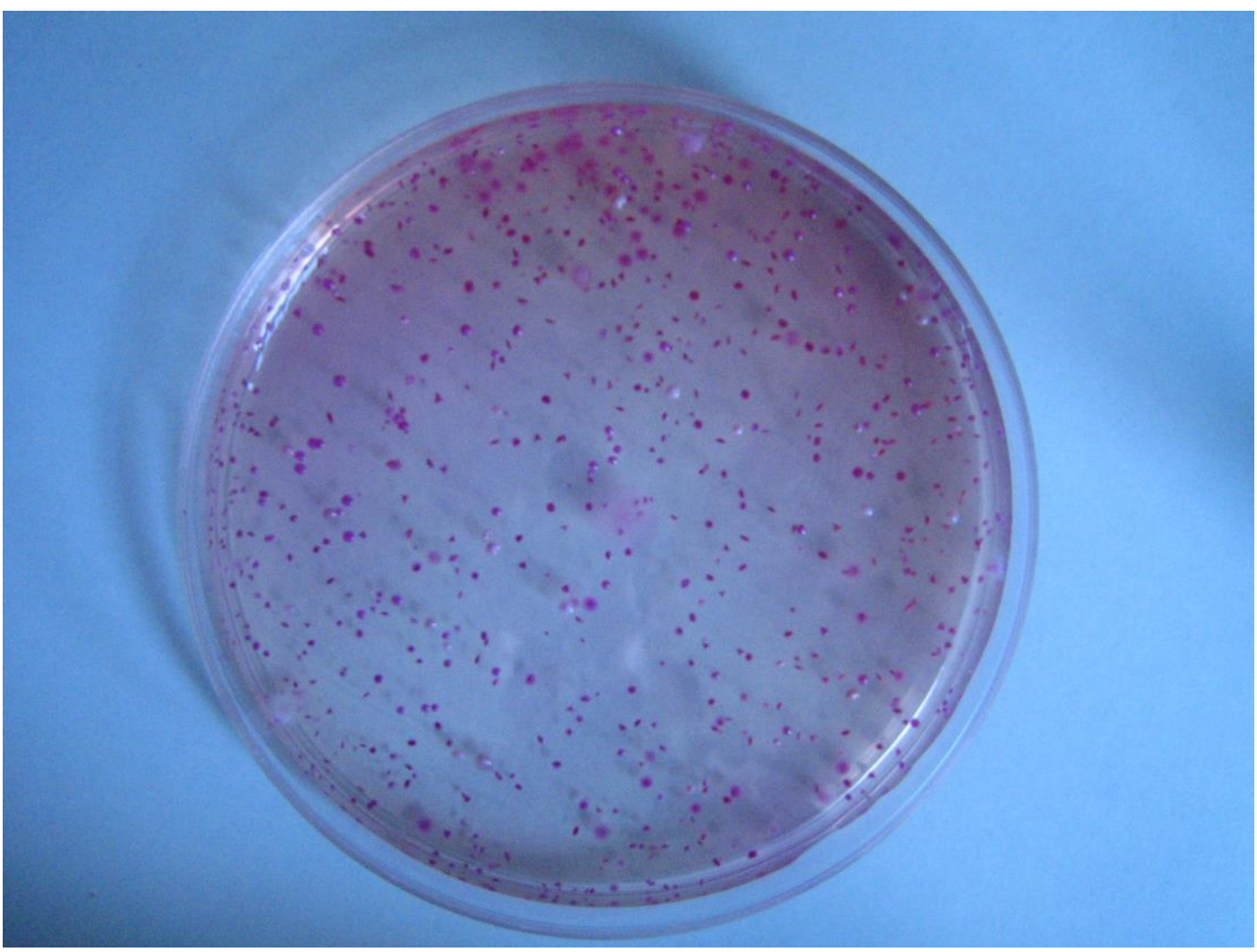




\section{M4. Vizsgált minták származási helye, ültetvény - és időjárási adatok}

\section{Termesztési helvek}
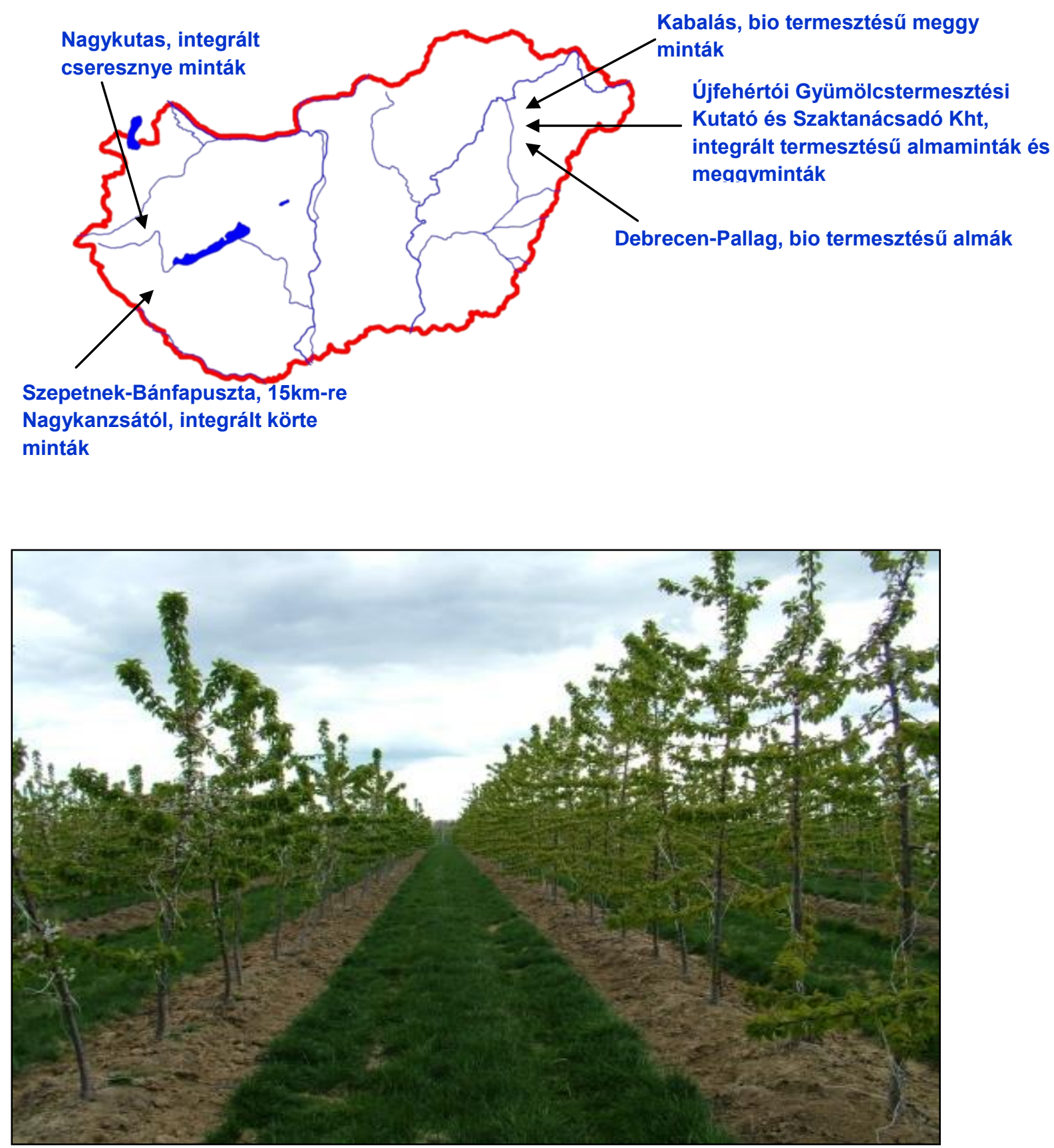

1. kép: Cseresznye művelési rendszer kísérlet (Nagykutas) (2008. évi kutatási jelentés) 
Termesztési helyek és gyümölcs ültetvények jellemzői

\begin{tabular}{|c|c|c|c|c|c|}
\hline & Klimatikus jellemzök & Talajtani jellemezök & Ültetvény térállása & Korona forma & $\begin{array}{l}\text { Alany } \\
\text { típusa }\end{array}$ \\
\hline $\begin{array}{l}\text { Ökológiai } \\
\text { termesztésű } \\
\text { meggy, } \\
\text { KABALÁS }\end{array}$ & $\begin{array}{l}\text { Az egész évi csapadékmennyiség átlagosan } \\
530 \mathrm{~mm} \text {, amelyből a vegetációs időszak } \\
\text { csapadéka } 340 \mathrm{~mm}\end{array}$ & $\begin{array}{l}\text { Dél-nyírségre jellemző: humuszos } \\
\text { homok, tipikusan nyírségi homoktalaj } \\
\text { a szelídebb formából. Laboratóriumi } \\
\text { vizsgálatok alapján } 0.74 \% \\
\text { humusztartalmú, } 4.7 \mathrm{pH} \text {-jú, }\end{array}$ & $\begin{array}{l}\text { Az ökológiai termesztés miatt } \\
\text { nagy térállás jellemző: } 8 \text { X } 6 \\
\text { m. A fák tág elhelyezése a } \\
\text { korona jó megvilágítását, a } \\
\text { terület, a fák mielőbbi } \\
\text { átszellőzését, a } \\
\text { gombabetegségek } \\
\text { fellépésének kisebb esélyét } \\
\text { célozta meg. }\end{array}$ & $\begin{array}{l}\text { Sudaras, szórt } \\
\text { állású koronát }\end{array}$ & $\begin{array}{l}\text { sajmeggy } \\
\text { (Cerasus } \\
\text { mahaleb } \\
\text { L. Mill.) }\end{array}$ \\
\hline $\begin{array}{l}\text { Ökológiai } \\
\text { termesztésű } \\
\text { alma, } \\
\text { DEBRECEN- } \\
\text { PALLAG }\end{array}$ & $\begin{array}{l}\text { Az egész évi csapadékmennyiség átlagosan } \\
\text { 530mm, amelyből a vegetációs időszak } \\
\text { csapadéka 340mm. }\end{array}$ & $\begin{array}{l}\text { Dél-nyírségre jellemző: Humuszus } \\
\text { homok / futóhomok (altípusa } \\
\text { lepelhomok) humusztartalom } 1 \% \\
\text { alatti. }\end{array}$ & Alma: $5,5 \times 3 \mathrm{~m}$ & Alma: orsó & M26 \\
\hline $\begin{array}{l}\text { Integrált } \\
\text { termesztésü } \\
\text { meggy és alma, } \\
\text { ÚJFEHÉRTÓ }\end{array}$ & $\begin{array}{l}\text { Nyírségre jellemző éghajlati, domborzati és } \\
\text { talajtani viszonyok. Évi átlaghöm.: } 9,5^{\circ} \mathrm{C} \\
\text { Évi csapadék: } 583 \mathrm{~mm} \\
\text { Napsütötte órák száma: } 1960 \\
\text { Éves átl. Napi max.: } 14,7^{\circ} \mathrm{C} \\
\text { Éves átlagos napi min.: } 5,6^{\circ} \mathrm{C}\end{array}$ & $\begin{array}{l}\text { Talajvíz } 2,5 \mathrm{~m} \text { alatt. Az ültetvény } \\
\text { talaja nem karbonátos többrétegü } \\
\text { humuszus homok, humusztartalma } \\
1,4 \% \text {. } \\
\text { pH(vizes): } 6,3 \\
\text { Mésztartalom: } 0 \% \\
\text { Összes vízoldható só: }<0,02 \% \\
\text { Hidrolitos aciditás: } 11,25\end{array}$ & $\begin{array}{l}\text { Alma: } 5 \mathrm{~m} \times 3 \mathrm{~m} \\
\text { Meggy: } 8 \mathrm{~m} \times 5 \mathrm{~m}(\mathrm{Az} \\
\text { Oblacsinszka fajta esetén } 5 \mathrm{~m} \\
\times 2,5 \mathrm{~m})\end{array}$ & $\begin{array}{l}\text { Alma: sövény } \\
\text { Meggy: } \\
\text { hagyományos } \\
\text { sudaras }\end{array}$ & $\begin{array}{l}\text { Alma: } \\
\text { M26 } \\
\text { Meggy: } \\
\text { sajmeggy } \\
\text { (Cerasus } \\
\text { mahaleb } \\
\text { L. Mill.) }\end{array}$ \\
\hline $\begin{array}{l}\text { Integrált } \\
\text { termesztésü } \\
\text { körte, } \\
\text { SZEPTENEK- } \\
\text { BÁNFA-PUSZTA }\end{array}$ & $\begin{array}{l}\text { Mikroklíma: Az ültetvény fekvése teljesen sík, délröl, } \\
\text { nyugatról szántóföldek, északról, keletröl a gyümölcsös többi } \\
\text { része veszi körül. Számításba vehető mikroklímatikus } \\
\text { megfigyelésünk nincs. Klímája a környezö területekétől csak } \\
\text { annyiban tér el, hogy az ültetvény kísérletbe vont része } \\
\text { öntözött. Kifejezetten szeles környék. }\end{array}$ & $\begin{array}{l}\text { A talaj genetikai talajtípusa: } \\
\text { „Nem podzolos, } \\
\text { agyagbemosódásos barna } \\
\text { erdőtalaj” }\end{array}$ & Körte: $4 \times 4,1 \mathrm{~m}$ & $\begin{array}{l}\text { Intenzív } \\
\text { (támrendszeres) } \\
\text { sövény }\end{array}$ & $\begin{array}{l}\text { Oltott } \\
\text { birs } \\
\text { alany }\end{array}$ \\
\hline
\end{tabular}




\begin{tabular}{|c|c|c|c|c|c|}
\hline & Klimatikus jellemzök & Talajtani jellemezök & Ültetvény térállása & Korona forma & $\begin{array}{l}\text { Alany } \\
\text { típusa }\end{array}$ \\
\hline $\begin{array}{l}\text { Integrált } \\
\text { termesztésü } \\
\text { körte, } \\
\text { FEKETESÁR }\end{array}$ & $\begin{array}{l}\text { Mikroklíma: A feketesári ültetvény speciális } \\
\text { elhelyezkedésü, minden irányból erdö veszi } \\
\text { körül. Ebböl adódóan, az ültetvénynek sajátságos } \\
\text { a mikroklímája. Megfigyeléseink szerint, a körte } \\
\text { egyes fenofázisai (rügypattanás, virágzás stb.) } \\
\text { Feketesáron kb. 4-5 nappal korábban indulnak, } \\
\text { mint a többi ültetvényünk esetében. A védett } \\
\text { fekvésben nagyobb mértékủ a páralecsapódás, } \\
\text { gyakran alakul ki köd. Az ültetvény lejt, K-Ny } \\
\text { irányú lefutású. A mélyebben fekvő, nyugati } \\
\text { területeken a pára kialakulása különösen gyakori, } \\
\text { időnként növényvédelmi problémát is okozva } \\
\text { (Venturia pyrina). }\end{array}$ & $\begin{array}{l}\text { Nem karbonátos, humuszos } \\
\text { homoktalaj }\end{array}$ & $\begin{array}{l}\text { Körte: } \\
6 \times 3 \mathrm{~m} 18,3663 \text { ha } \\
5 \times 3 \mathrm{~m} 65,0058 \text { ha }\end{array}$ & Szabadorsó & $\begin{array}{l}\text { Oltott } \\
\text { birs } \\
\text { alany }\end{array}$ \\
\hline $\begin{array}{l}\text { Integrált } \\
\text { termesztésű, } \\
\text { cseresznye, } \\
\text { NAGYKUTAS }\end{array}$ & $\begin{array}{l}\text { A terület a Dél-Kemeneshát tájegységben, } \\
\text { Kalócfapusztától északnyugatra található. A } \\
\text { terület felszíne hullámos. A területhez közeli élő } \\
\text { vízfolyás a Szentmártoni-patak. } \\
\text { A Szász-féle besorolás szerint a } 23 \text {-as } \\
\text { meteorológiai körzetbe tartozik. Éghajlatára a } \\
\text { mérsékelten meleg, csapadékos időjárás jellemző. } \\
\text { Tavasszal az utolsó fagy április } 10-15 \text { között } \\
\text { szokott elöfordulni. Évi átlagos csapadék: } 727 \mathrm{~mm}\end{array}$ & $\begin{array}{l}\text { Agyagbemosódásos barna erdőtalaj } \\
\text { pH (vizes): } 6,4 \\
\text { Összes-só: }<0,01 \mathrm{~m} / \mathrm{m} \% \\
\text { Szénsavas mész: }<0,1 \mathrm{~m} / \mathrm{m} \% \\
\text { Humusz: } 1,37 \mathrm{~m} / \mathrm{m} \%\end{array}$ & $\begin{array}{l}\text { Cseresznye: sorszélesség: } \\
3,50 \mathrm{~m} \text {, tőtávolság: } 1-1,20 \mathrm{~m}\end{array}$ & $\begin{array}{l}\text { Központi } \\
\text { tengelyü orsó } \\
\text { korona. }\end{array}$ & $\begin{array}{l}\text { sajmeggy } \\
\text { (Cerasus } \\
\text { mahaleb } \\
\text { L. Mill.) }\end{array}$ \\
\hline
\end{tabular}




\section{Időjárási adatok}

I. Integrált termesztésủ körte és cseresznye minták termesztési helyének közelében lévő településröl (Egyházasradóc) származó időjárási adatok: (az adatok forrása: http://zivipotty.hu/idojaras20072011.html)

Hömérséklet-csapadék: 2007 és 2011 között az évi középhömérséklet átlagos értéke $11{ }^{\circ} \mathrm{C}$ körül ingadozott. Az időszakot összességében kismértékü melegedés jellemezte, de 2010-ben átmenetileg hüvösebb volt. Ez a lehülés legnagyobb mértékben a maximumokban mutatkozott meg, míg a minimumok tekintetében alig történt visszaesés a 2009-es évhez képest. Az éves csapadékösszegek az első 3 évben (2007-2008-2009) viszonylag egységesen 750 mm körül alakultak, míg 2010-ben kiugróan magasas, kevéssel 900 mm-t meghaladó csapadék hullott. (Ez a csapadékos időjárás okozta a kismértékủ visszaesést a hőmérsékletben.)

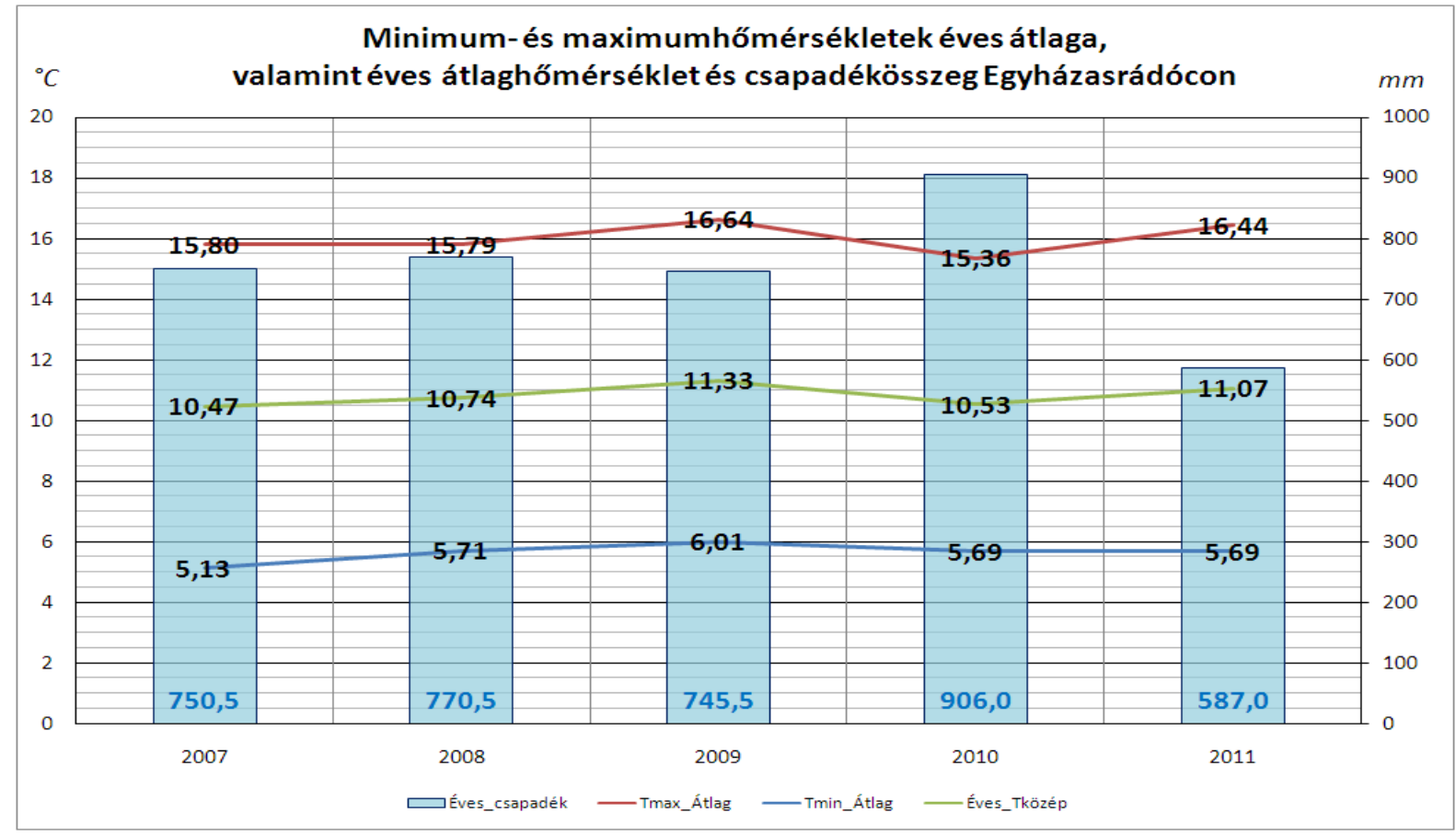

Hőmérsékleti jelzőnapok: A hőmérsékleti jelzőnapok tekintetében legszembetűnőbb a fagyos- és nyári napok növekedése, melyben csak a 2010-es év jelentett eltérést. Ekkor ugyanis a gyakori nyári csapadék miatt az előző éveknél jóval kevesebb nyári nap került regisztrálásra. 


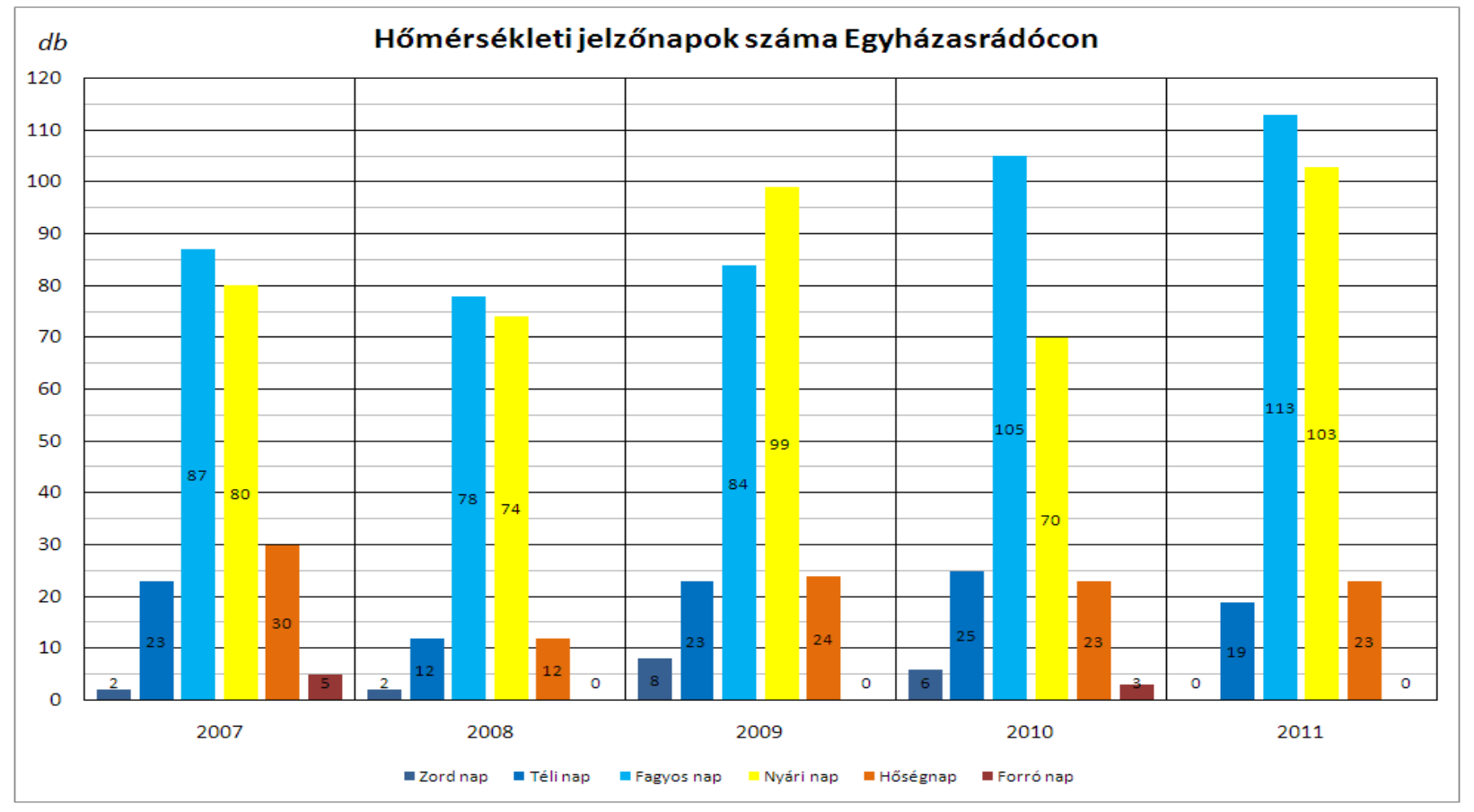

Csapadékos és havas napok: A csapadékos napok (olyan napok, amikor csapadék hullott, attól függetlenül, hogy esett-e belöle mérhetö mennyiség) éves száma 150 körül ingadozott, ezen belül azonban előbb emelkedett, majd ismét csökkent. A legszembetünőbb érdekesség, hogy a legtöbb csapadékos nap nem a legcsapadékosabb évben, 2010-ben fordult elö, ami jól mutatja, hogy akkor a sok csapadék gyakori nagy csapadékösszegekből tevődött össze.

A havas jelzőnapokat vizsgálva egyértelmüen kitünik, hogy a 2010-es évben esett a legtöbb hó, míg a legkevesebb 2008-ban és 2011-ben.

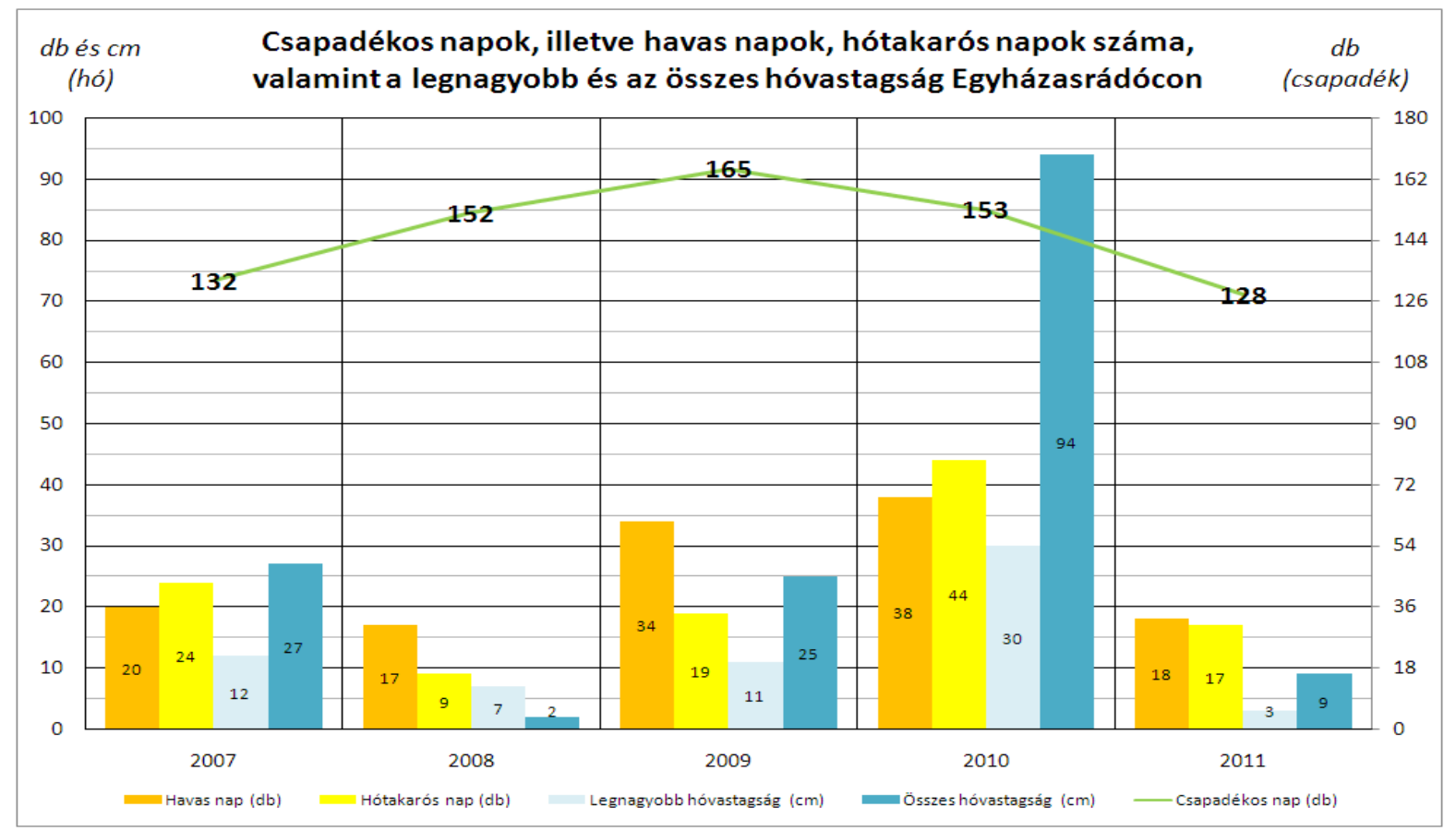


II. Bio és integrált termesztésü alma és meggy termesztési helyének közelében lévő településről (Karcag) származó időjárási adatok: (az adatok forrása: http://www.portal.agr.unideb.hu)

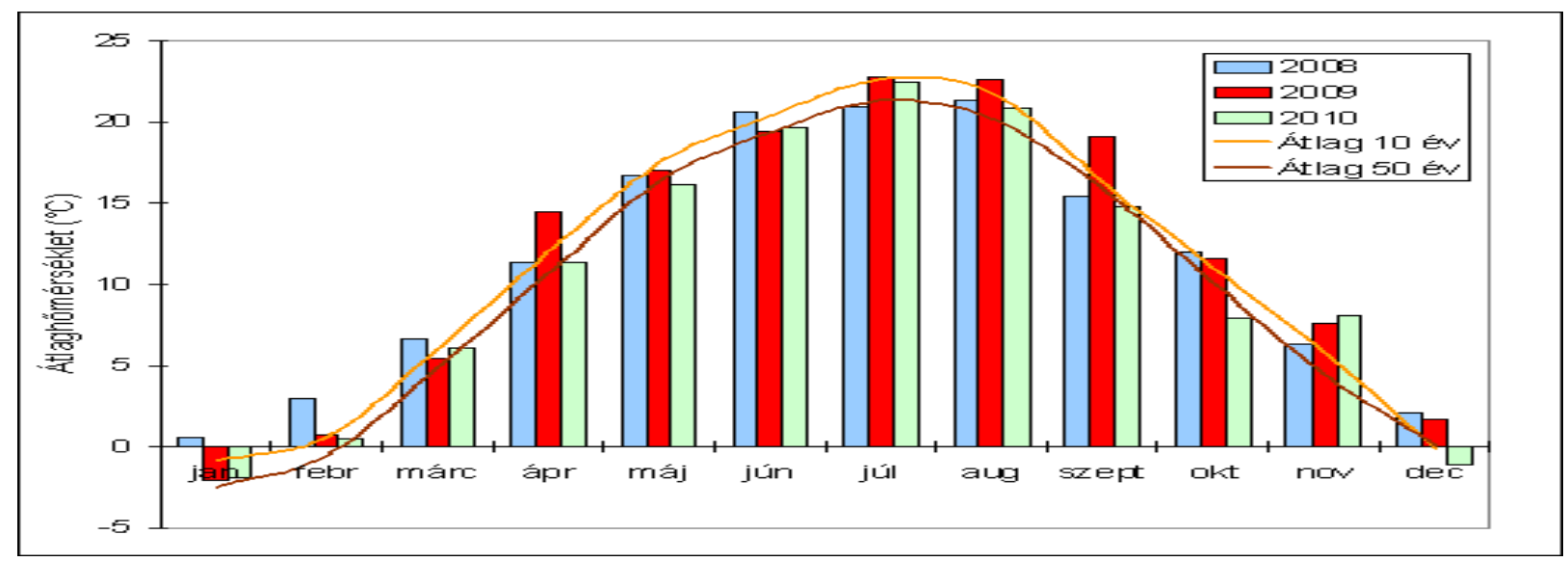

1. ábra:A havi átlaghömérsékletek alakulása (2008-2010)

A 1. ábrán jól látható, hogy a 2009-es év hőmérséklete meghaladta mind a 10 éves, mind az 50 éves átlagot.

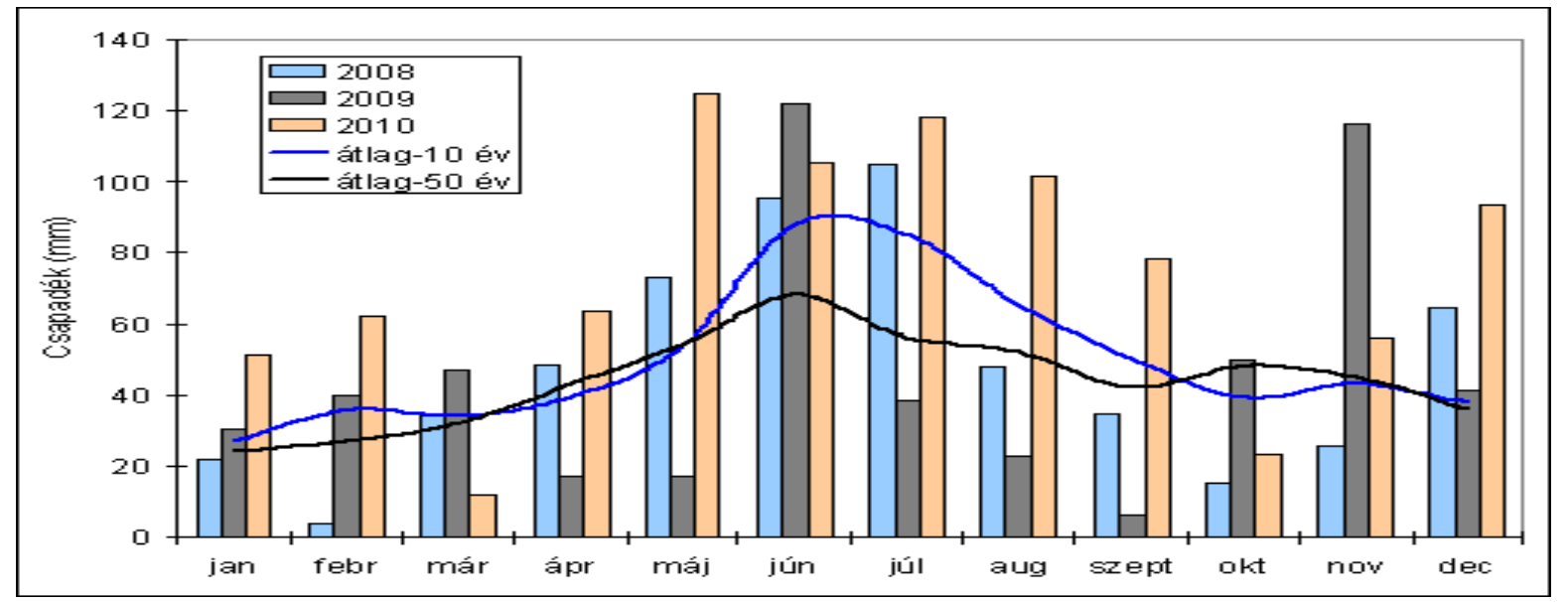

\section{2. ábra:Havi csapadékmennyiségek alakulása 2008-2010}

Ha csapadék szempontjából összehasonlítva a 10 éves és az 50 éves átlagokat a csapadék évi eloszlása is eltolódott a régebbi csúcsokhoz képest, illetve a 2010-es év rendkívül csapadékosnak bizonyult, illetve a sokévi adatokhoz képest 2010 volt a legcsapadékosabb ( $889 \mathrm{~mm} / \mathrm{e} v)$ (2 ábra-3. táblázat).

\begin{tabular}{|c|c|c|c|c|c|c|c|c|c|c|c|c|c|}
\hline Csapadḱk immi & jaruár & felauár & március & ácrilis & máius & júrius & július & auaustus & szertember & chtóber & november & december & Összesen: \\
\hline 2001 & 325 & 20 & 61.5 & 542 & 22.1 & 116.4 & 119.8 & 278 & 101.9 & \begin{tabular}{|l|}
2.7 \\
\end{tabular} & 226 & 7.1 & 570.6 \\
\hline 2002 & 3.7 & 18.1 & 69 & 216 & 419 & 86.2 & 63.1 & 472 & 66.6 & 280 & 259 & 30.4 & 439.6 \\
\hline 2003 & 33.7 & 452 & 56 & 4.1 & 262 & 48.4 & 252 & 193 & 275 & 113.7 & 258 & 6.7 & 381.4 \\
\hline 2004 & 353 & 402 & 66.0 & 442 & 266 & 78.2 & 155.3 & 886 & 31.5 & 33.8 & 710 & 36.4 & 707.1 \\
\hline 2005 & 150 & 43.4 & 2.1 & 70.1 & 378 & 74.8 & 152.2 & 152.9 & 72.4 & 9.2 & 310 & 622 & 7431 \\
\hline 2006 & 283 & 56.1 & 57.7 & 703 & 682 & 1028 & 379 & 108.0 & 9.1 & 238 & 209 & 1.9 & 5850 \\
\hline 2007 & 176 & 462 & 26.6 & 00 & 979 & 49.7 & 37.1 & 36.3 & 74.1 & 918 & 35.1 & 356 & 5480 \\
\hline 2008 & 215 & 38 & 34.1 & 482 & 732 & 95.1 & 104.5 & 480 & 345 & 152 & 25.4 & 64.4 & 5679 \\
\hline 2009 & 30.4 & 40.1 & 46.9 & 170 & 169 & 1219 & 383 & 22.7 & 60 & 49.7 & 1162 & 413 & 547.4 \\
\hline 2010 & 51.4 & 62.3 & 12.1 & 633 & 1248 & 1052 & 118.1 & 101.6 & 779 & 23.1 & 562 & 93.1 & 89.1 \\
\hline śtłogio ér & 26.9 & 35.7 & 34.0 & 39.3 & 53.6 & 87.9 & 8.2 & 602 & 50.2 & 30.1 & 43.0 & 37.9 & 567.8 \\
\hline śflug $50 \mathrm{ev}$ & 240 & 270 & 32.0 & 430 & 540 & 8.0 & 560 & 520 & 420 & 480 & 450 & 36.0 & 527.0 \\
\hline
\end{tabular}

3.táblázat: Havi csapadékmennyiségek alakulása 2001-2010 (Forrás: DE AGTC KIT Karcagi Kutató Intézete) 


\section{Köszönetnyilvánítás}

Szeretném megköszönni a Központi Élelmiszer-tudományi Kutatóintézet egykori igazgatójának, Dr. Bánáti Dianának, valamint a Mikrobiológiai Osztály vezetőjének Dr. Beczner Juditnak, hogy lehetőséget biztosítottak kísérleteim elvégzésére.

Továbbá köszönöm a Mikrobiológiai Osztály valamennyi dolgozójának a szakmai segítséget. Külön köszönöm az Analitikai Osztály egykori vezetőjének Dr. Daood Husseinnek és egykori munkatársainak Sassné Dr. Kiss Ágnesnek és Tóthné Dr. Markus Mariannának az analitikai kísérletekben nyújtott segítséget.

A kísérleteimet a BioDeb07 „bio/organikus és integrált gyümölcstermesztést megalapozó biológiai alapok fejlesztése és technológiák kidolgozása” címü Jedlik Ányos pályázat keretében végeztem el. 